
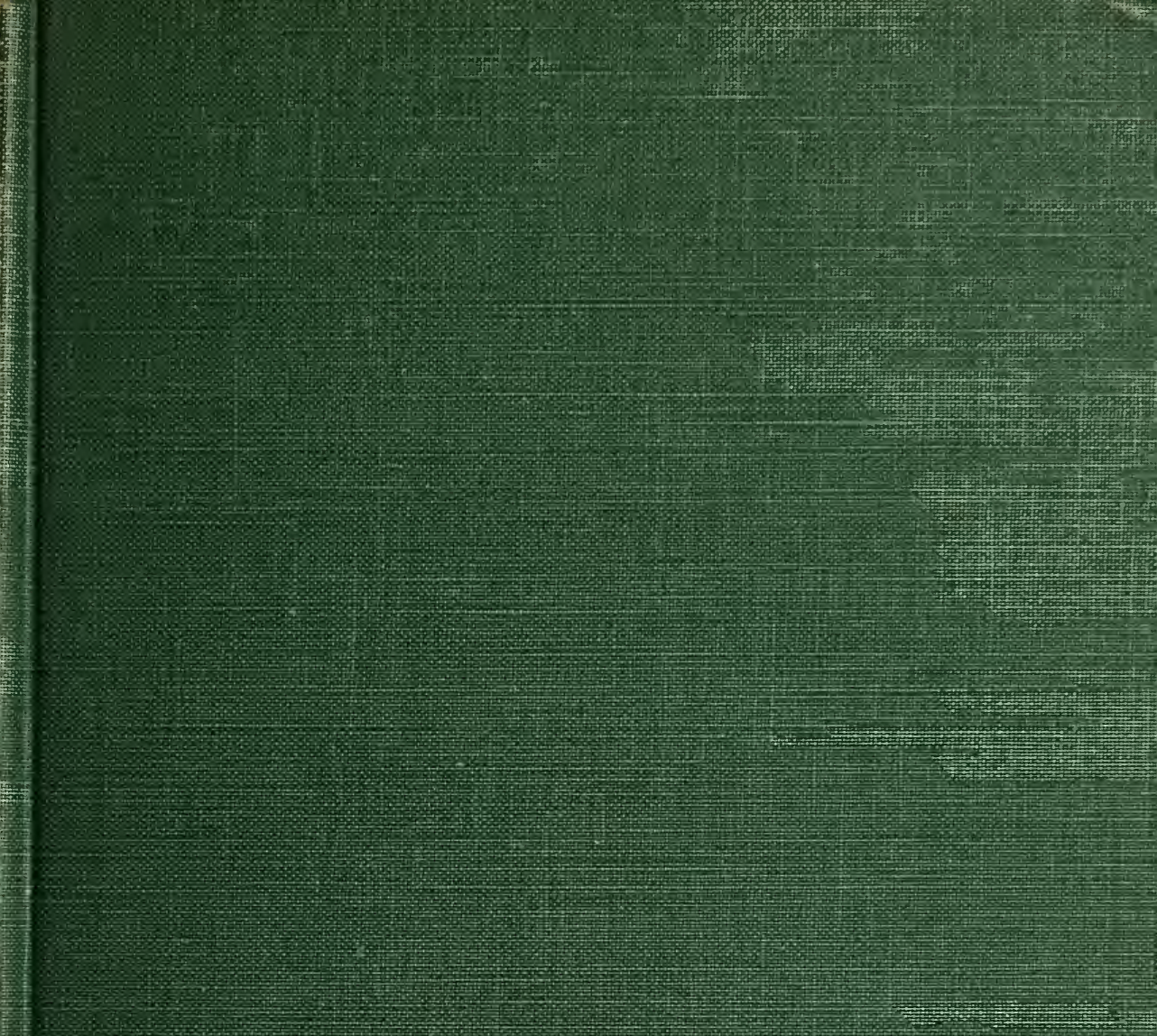
I El tu 


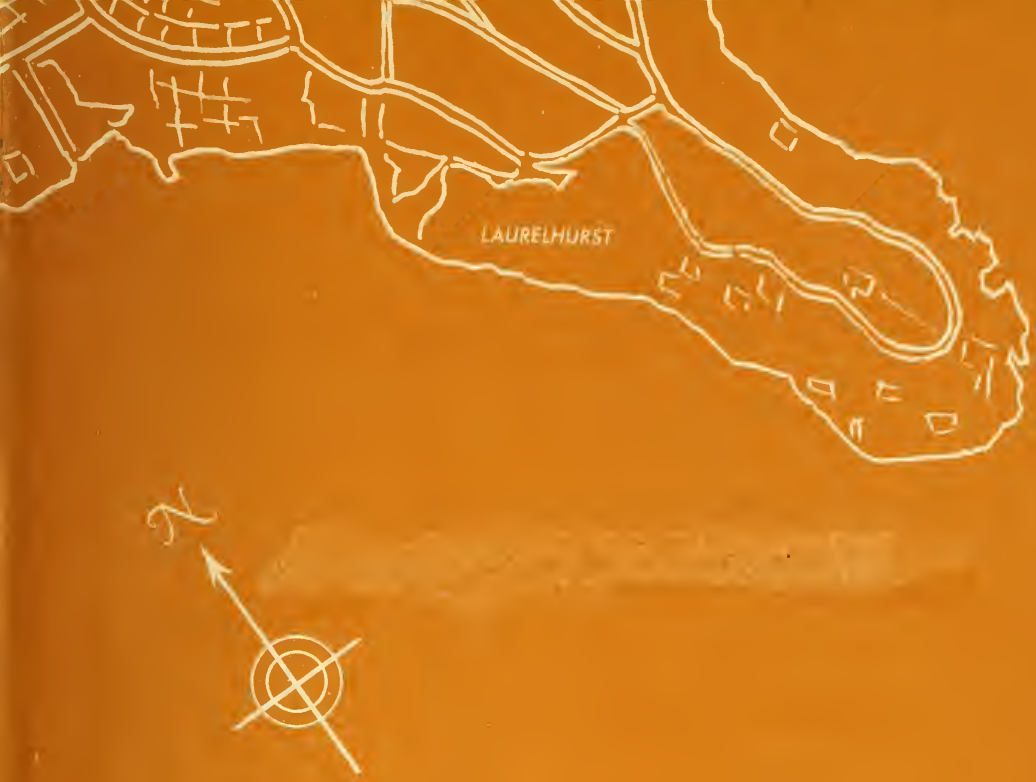

LAKE

WASHINGTON

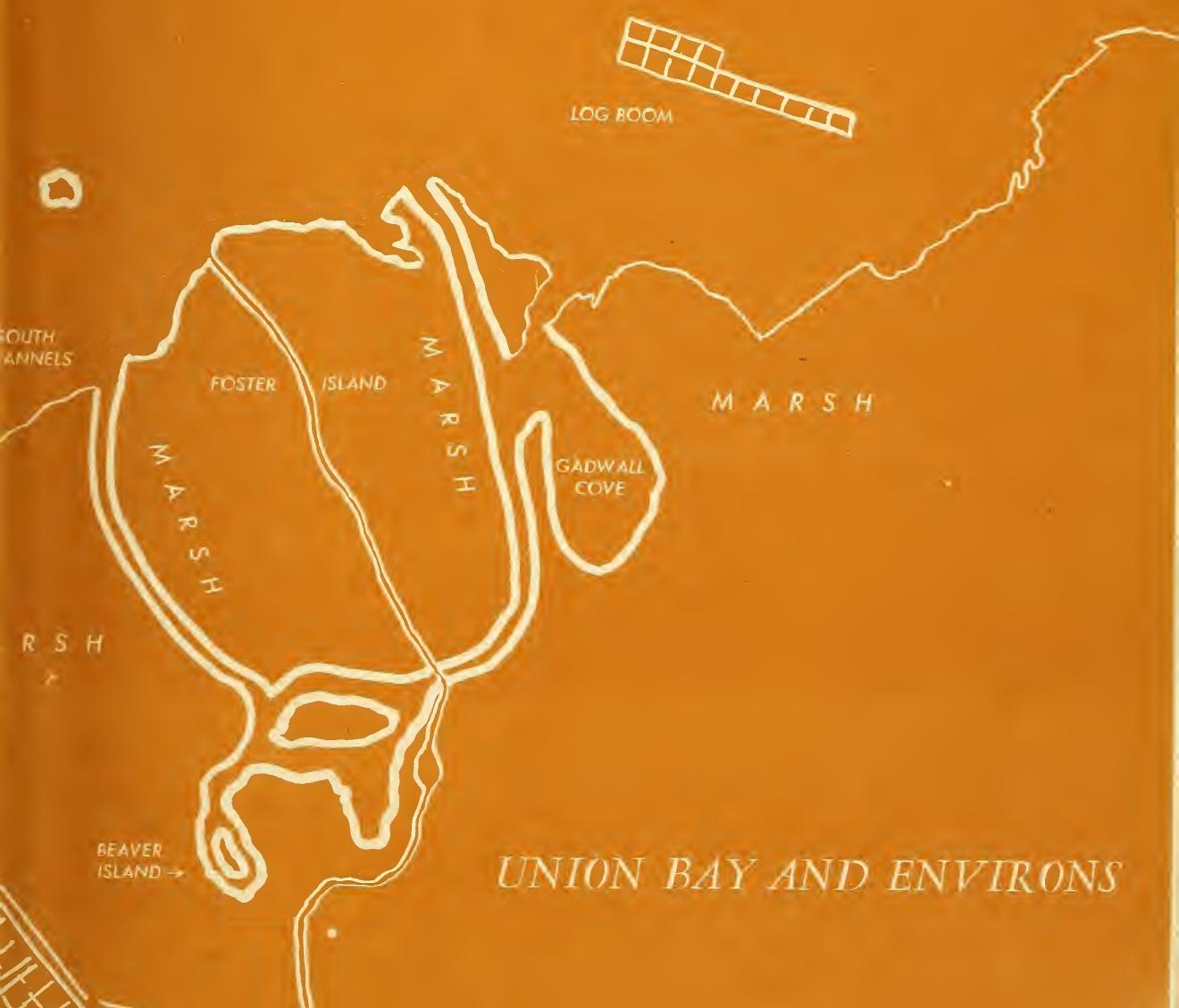


Digitized by the Internet Archive in 2011 with funding from LYRASIS members and Sloan Foundation 


\section{UNION BAY}

The Life of a City Marsh 
By the same authors PILCHUCK: THE LIFE OF A MOUNTAIN 


\title{
union bay
}

The Life of a City Marsh

\author{
By HARRY W. HIGMAN \\ and EARL J. LARRISON
}

Illustrated by Edmund F. Saroyer

University of Washington Press Seattle. I95I 
Copyright, 1951, by Harry W. Higman and Earl J. Larrison All rights reserved Printed in the United States of America BY AMERICAN BOOK-KNICKERBOCKER PRESS, INC., NEW YORK 


\section{Acknowledgments}

PERHAPS THE MOST INTERESTING AND CERtainly the most pleasing aspect of the preparation of this book was the generous response which we received from those whom we asked for assistance. Dr. George B. Rigg, authority on bogs and marshes, checked parts of the manuscript and supplied valuable information. Mr. and Mrs. George A. Leis of the University canoehouse continually advised us of changes in the area. We express our thanks to Dr. Erna Gunther, Executive Officer of the Department of Anthropology, University of Washington; Dr. Victor B. Scheffer, Biologist of the U.S. Fish and Wildlife Service; Dr. Alexander B. Wetmore, Secretary of the Smithsonian Institution; Mrs. Martha R. Flahaut, Curator of Biology, Washington State Museum; and Malcolm T. Jollie, Department of Biological Sciences, University of Idaho. We have benefitted from the experiences of other students of Union Bay, especially Professor Elizabeth L. Curtis, University of Washington; Dr. Robert C. Miller, Director of the California Academy of Sciences; Warren Flock, Walter Hagenstein, and the late Samuel F. Rathbun. J. Ronald Todd, of the University of Washington Library, and Miss Ernestine 
Brown, Willard O. Youngs, and Miss Wanda Z. Brockman of the Seattle Public Library, and Miss Florence Waller, formerly of that institution, have aided our researches in the literature. Finally we acknowledge our great indebtedness to Mr. and Mrs. Carl S. English, Jr., botanists, for much information as well as a critical reading of the whole manuscript; and to Robert B. Hitchman for his constant and helpful criticism during the preparation of each chapter and the final assembly.

To all of these and to many others whose names are not mentioned we are truly grateful.

HARRY W. HIGMAN

EARL J. LARRISON 


\section{Contents}

Introduction 1

1. The Marsh in Union Bay 5

2. How the Tule Wrens Acquired Summer Quarters 9

3. The Marsh Is a Hotel 20

4. The Tail Slapper 33

5. A Worm's a Worm 48

6. The Bill of Fare 62

7. Shells on Union Bay 74

8. The White Pigeon 85

9. The Track Near the Marsh 98

10. Introducing Something New $\quad 110$

11. Arrowhead, Squaw's Toes, and Other Things 124

12. The Henpecked Shorebird That Goes to Sea $\quad 139$

13. Among the Guests Registered 152 
15. How a New Water Witch Came to the Marsh

17. How the Green Heron Wandered

18. Marsh Symphony

19. Quintet

20. Pigskins and Dowitchers

21. Sky Sweepers

22. Wild Fowl and Men

23. Who Killed Cock Robin?

24. Fog Is a Puzzlement 288

25. The Specialist Loses Control 


\section{UNION BAY}

The Life of a City Marsh 



\section{Introduction}

FOR SOME YEARS WE HAVE HAD THE OPPORtunity to observe the life of a marsh, a spot not located in some remote country area but near a well-populated district in the city of Seattle. This marsh lies along the eastern portion of the University of Washington campus and occupies a part of pouch-shaped Union Bay. A ship canal passes through the bay and connects Lake Washington, of which the bay is a part, with the salt waters of Puget Sound, about five miles away. Large locks have been constructed at Ballard, at the western end of the canal. The bay area is a contrasting mixture of fine residences, the University of Washington Arboretum, the margin of the campus, and the marsh. This contrast has furnished us with an excellent opportunity to see how wild animals and plants could live in harmony with their human neighbors.

We visited the area continually-an expression of our great interest in the natural sciences. This Union Bay marsh was the nearest place in the city where we could come in contact with wildlife. Visits required so little time and preparation that they could be made in the odd hours that we were able to find each week. 
We found much to attract us. The presence of a football stadium and athletic fields on the edge of the area brought thousands of people to it. We watched the continual reconcilement of apparently unreconcilable things. We could look in one direction and see the crowds and had only to turn in another to glimpse newly arrived birds. We could hear the honking cars which carried the noisy spectators from the games, while close to us that brown-striped resident of the cattails, the bittern, honked as it stood guard over its nesting area. We began to understand how easily wildlife could adapt itself to close association with man if man would only cease his predation. We learned that the wild things would lose much of their wildness if man's conduct did not constantly remind them that only by preserving their wildness could they exist. We found that some wild creatures could continue to carry on their normal lives with little friction, while the lives of others were influenced by man to the point of extinction.

For a long period it was the fashion to eliminate man from the typical wildlife story. The animals which were described lived their lives in their native habitats, unmolested and uninfluenced by people. But now, in the marsh, in the mountains, on the pampas of South America, in the forests of Canada, and in nearly all hitherto remote places, conditions have changed. Men hunt everywhere. Other activities, such as drainage, filling, tree-cutting, building-due to commerce and agriculture-directly and sometimes devastatingly affect wildlife. To leave man out of the consideration of wildlife is to ignore one of the most important factors.

This book is primarily a description of the living aspects of the marsh. If we touch on such subjects as anatomy, psychology, and physiology, it is with the hope that such discussion will serve to explain more fully the incidents about which we write. We have endeavored to combine our laboratory experience, what we have gained from talks and lectures 
of specialists and, above all, what we have observed in the field, to interpret the activity of the area.

In our previous book, Pilchuck: the Life of a Mountain, we described the amazing orderliness which governed the life and affairs of a mile-high mountain which stands at the edge of the Cascade Range, thirty-three miles from Seattle. In this story of a city marsh we have tried to emphasize what we consider its most interesting aspect-the result of the competition between man and wildlife.

We have visited this area for years. We have watched the impact of nature on man and man on nature, and have recorded our experiences so that those who are interested can travel with us through this city marsh where wildlife exists and goes its way within the sound of automobile traffic, and near the many activities of a University, a ship canal, a commercial district, and a community of homes.

For the sake of simplicity and clarity we have written the book as the reporting of a single observer, an instructor in biology. We have selected incidents such as the ordinary persistent observer could see and describe for himself. The conjectures and questions are those of the kind which would be posed by the average visitor rather than by a scientist. The incidents and records set forth are based on actual happenings and have been carefully selected to give a picture of this small but complex and fascinating area. 



\section{The Marsh in Union Bay}

\section{1.}

ON A SUMMER'S DAY WHEN THE CATtails have just passed their prime the marsh near my home is purple with the blooming loosestrife. Beneath the surface of the shallow water delicate foliage weaves and undulates with every passing ripple. The white and gold of the water lilies make a bold contrast to the dark green of the floating pads. If the day is dull, the swamp waters appear oily black, but when the sun is bright, the reflections of the great clouds from the Pacific Ocean are so well mirrored that they seem to float in the water below as well as in the sky above.

Not only does the area gleam with silent color, but also it pulsates with life in its various phases-noisy, hungry, angry, joyful, and adventurous. In the active part of the seasons the change and the bustle astonish me. So many old guests have gone, so many new ones have appeared, so much activity is displayed by the visitors that I feel that I am looking, not at a static home for a few permanent residents but at a place which furnishes food and shelter to numerous transients.

It is a unique place, this marsh. Man, by building the ship canal, lowered the water of the bay until its margins became 
a series of exposed flats. Man is therefore responsible for the marsh. If the present trend continues, man, by continual filling, drainage, and building, will some day destroy it. In the past few years the city has nibbled at corners and filled low spots so that the acreage has been slowly but steadily shrinking. People frequently visit it-to boat in the deeper water, to fish, trap, or stroll where the firmness of the soil permits.

The vegetation of the area has been self introduced. No extensive plantings have been made. No landscape gardeners have destroyed its naturalness. Only a few canals have been dredged. They stand naked and bare for a year or two, but then their banks are taken over by the vegetation and they become a part of the marsh scene. No great influence of man is apparent. Nevertheless, part of the area's uniqueness lies in the government control exercised over it. For years, government engineers in charge of the locks have pushed buttons and thus controlled water levels which, unknown to them, have decreed the nature of the marsh program: whether the beggar's-ticks would grow here or there, whether the change in depth would give a temporary advantage to the cattails or loosestrife in their constant battle for territory, whether the shorebirds would find enough exposed flats to justify their stopping on their fall migration, whether Gadwall Cove would be clear of, or clogged with, plant growth.

My home is but five miles from the center of the city. I can drive to the marsh in less than five minutes. My work is at the University on the hill above the location, not quite a third of a mile away. From the windows of many of the campus buildings I can see the marsh, whose dark waters are surrounded by browns or greens of the marsh vegetation, according to season. The huge freight boats crawl through the canal, looking as much out of place as a black bass might look in a goldfish bowl. The open waters of Union Bay 


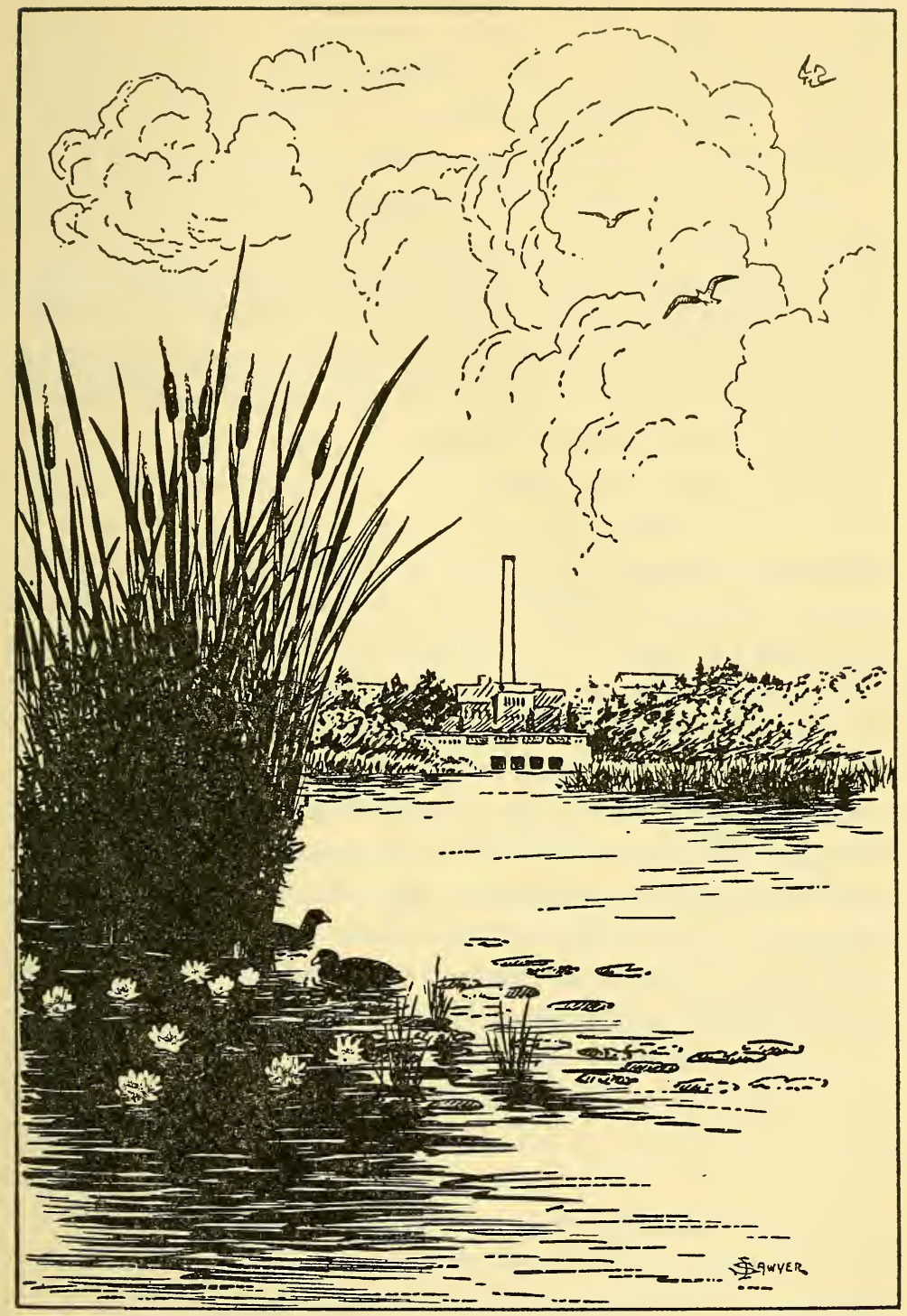


carry the white sails of fast-moving pleasure boats. Power boats often drag water skiers. Sometimes a tanker, airport bound, moves along. It is a pleasing sight, seldom without activity. There is nothing about it to indicate that wildlife can be seen by those who are curious enough to look for it.

And yet the wildlife has managed to adjust itself to this activity. There are few quiet days in the history of the place. Each season has its guests which come at quite fixed times, stay for definite periods, and are replaced by others when they leave. Winter transients and regulars, spring migrants, summer residents, fall visitors, and all-season guests provide a constant and impressive change of population.

The life which one sees in this marsh is mostly bird life, with now and then a beaver, a muskrat, a mink, or an otter which has stopped for a few days while on its tour of the streams. Just animal life? Yes, just animal life, but birds and mammals as interesting as people so that, when I pick an individual from among them as a radio announcer with a "roving mike" might select a man from a crowd, I usually unravel a story that holds every element of drama.

I have been visiting the area since a boy in high school, so that now I know it as I know the neighborhood about my house-the kind of neighbors, what they do, something of when they come and go, and a little of the happiness and difficulties which beset them. It is of these aspects of the marsh which I propose to write. 


\section{How the Tule Wrens Acquired Summer Quarters}

\section{2.}

TWO TULE WRENS, MORSELS OF BROWN birds with long bills and saucy tails, flew about the margins of a little pool in the cattails of the marsh. They had not casually drifted in. A definite urge had brought them; they had come early to make proper reservations.

On the nearby hillsides of the University of Washington campus, willows and alders had begun to leaf. In the stadium a few rods from the marsh shore, athletes worked in their light track outfits as they trained for their various specialties. Girl and boy students walked hand in hand. Others stopped to watch the first practice of the baseball squad. Every sunny afternoon the manager of the canoehouse busied himself in launching canoes for spring-struck classmen who wanted to forget all school work and drift about and dream in the fresh warmth. Yes, any observer could be quite sure that spring had come to the uplands.

But winter had not yet loosened its grip on the marsh even though the canoehouse manager, who was also the recorder of all marsh activity, had seen the tree swallows, our first spring migrants, over a month before. High and cold water had held back all swamp vegetation except the horsetail, 
whose green jointed stalks had sprung up in many sheltered spots. No other new marsh growth had appeared. The whole area lay lifeless, a mixture of what might be called "discouraged shades of brown."

Nevertheless, the tule wrens had arrived. I had waited for them since the tree swallows began their seemingly hopeless task of finding flying-insect food in the cold March breezes. I had reasons for wanting to see the wrens. I had been reading and hearing much about the definite ways in which birds appropriated nesting locations and then stayed in the area of their choice. They would hold it against all newcomers so that when a mate arrived there would be shelter and food for the nesting and the raising of the young. The subject so fascinated me that I decided to investigate it myself. No birds seemed more suitable for observation than the tule wrens: they were plentiful, they nested close to the ground, and few places could provide such easy access as the low-growth, treeless sections of the marsh.

Although I found tule wrens in many places in the area, I was not satisfied until I came to the little pool among the cattails. There were no cottonwoods or willows in the foreground, and those which stood at some distance in the rear would be an advantage rather than a hindrance for they would insure quiet water and, for my own comfort, freedom from the worst of the spring winds. A bittern flushed as I made my inspection, and it flew away croaking-stripes plainly visible in the sun and the claws of its trailing feet pointing upward. This bird, too, was concerned with the problem of space for the season and I was quite sure that it had already chosen a cattail-filled spot back from the water. A song sparrow-small, cheerful, and friendly-flitted about among the lower third of the cattail stalks. Then two tule wrens, one on each side of the small cove, scolded me as I paddled the canoe around. This was the exact place I had 


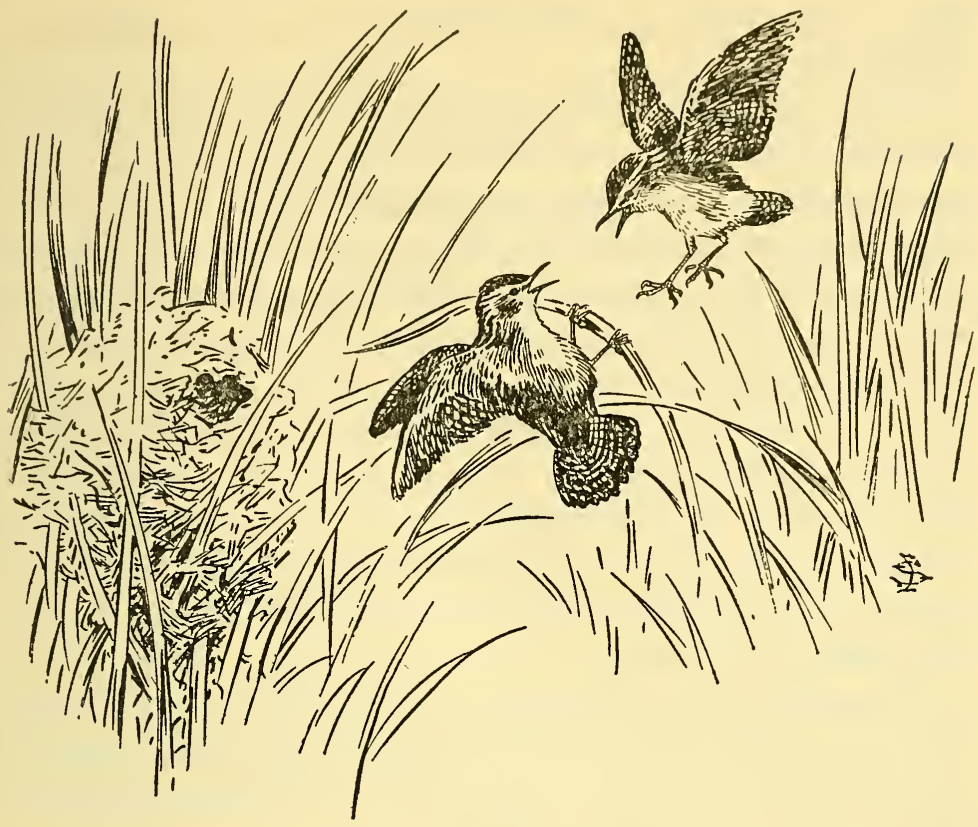

been looking for. Here was room with bath for each pair of birds and its family to come, here was an opportunity to watch squabbles and disputes over intermediate territory, and here was a place for sheltered and unobstructed observation.

I began to make regular visits and found, as I had suspected, that the two birds had already chosen their space for the season, one on either side of the pool. Presumably, the area which each had taken was of a size that would provide food for itself, its mate, and its future family. When I appeared, the bittern would usually flush, which was quite a sure sign that its nesting site would be nearby. Often I would see it make a short circle and then drop quietly into that area. The song sparrows continued their unconcerned and cheery investigation of the lower sections. I watched the scene with much interest but with a sense of queerness that I did not 
place at first-then I understood it. It was the proximity to civilization.

When I first thought of studying biology, I had pictured scientific inquiries in connection with long treks into some jungle with porters lugging my equipment and supplies. Now I was studying wildlife, but where were the porters and the wilderness? The subject didn't lack appeal, but where was the romance in such a location?.I was just a good golf shot from the stadium, and close enough so that I could hear the coaches bawling out the players in spring football practice, and the profs calling "fore" on the golf links. I could even hear the crack of the bat when some fellow on the baseball squad connected with a ball in batting practice. What was exciting about such research? I voiced my thoughts to an older friend of mine.

"Remember the old saying," he replied. "Adventure is where you find it.' If you work hard enough maybe someday you may get to a place where a lion will bite out the seat of your pants, so just be patient."

I learned much as I sat long and quietly in my canoe and watched the birds. The wrens patrolled their territory constantly as a policeman might cover his beat. They moved from cattail to cattail, sometimes high and now and then at water level, where the tangle must have appeared to them as a windfelled forest appears to men. This lower strip was claimed by the song sparrows who dashed at the wrens when they came too close. But the sparrows seemed to recognize the wrens' right to nest and feed in the upper part of the cattails and did not molest them if they stayed there.

The birds selected certain high cattails in their areas for singing points. As each wren moved from one to another post in its reservation, it announced its presence by singing, not light and sweet trills, but by forceful, bubbling, and harsh notes which might be compared in quality to the rather questionable texture of a bathroom serenade. The song completed, 
it moved to the next point with such regularity that, although it sometimes missed certain stations, I could anchor the canoe at a likely place and be reasonably sure of having the bird stop, sometimes within five feet of me, and sing on the cattail I had selected. I thought that I could detect competition in the singing of the two wrens, for the louder the one bird sang the louder the other became, and if one appeared to concentrate on a phrase the other often repeated it. Obviously it was serious business. Perhaps its quality and strength might be of much importance in the securing of a mate.

Each bird put everything into the song, singing with its head pointed to the sky, its long slender bill wide open, its brown body shaking with the effort. The perky tail stood erect or tipped forward toward the bird's back. Now and then the wren would face a new direction and publish its claim to the territory. Often one bird abruptly ceased singing, flew a few feet, searched for food, then as abruptly flew to a high cattail and began again. Sometimes, even before the females appeared and before regular nest work began, a male would prowl around with a billful of cattail down as if to say "Come along, old girl, I'm ready to start house building." Most of the time they moved and sang, nervously fed or pretended to feed, and then took a new station to resume the performance. While they sang, the wind would ruffle their soft feathers.

The movements of the birds appeared jerky and nervous but always forceful. They were in a militant mood. Neither of them ever considered a policy of appeasement when they were engaged in territorial arguments. Each had definite ideas as to its rightful leasehold and would fight to defend it. Each moved about constantly with its claws clinging to a cattail stalk or to the head and releasing a fine spray of cattail down to be scattered by the wind. Invariably with the movements came their burst of discordant but almost frenzied song. 
Every authority I read had agreed on the importance which song played in the maintenance of territorial rights. Most of them thought that it has two purposes-one to announce occupancy and to warn off competing males and the other to inform the females of the presence of a lone bachelor.

As if to prove it a song ceased and one of the little fiveinch birds dashed toward the invisible boundaries of no man's land-the other had advanced into disputed territory. The attack was straight and vicious. The birds squeaked; they mixed in a moment of savage battle; a soft feather drifted away as they rolled and dropped in fierce grip; the battlers disengaged and the victor pursued the vanquished for a few yards. A moment's quiet followed, then both birds sang, as if to indicate that, while there was to be no nonsense about invasion, resentment ceased after the rules were observed. Time and time again I watched the same little drama. Every struggle ended with the repulse of the invading bird. But if the victor went too far in its pursuit and entered the other bird's territory, then the pursued, as if convinced of the justice of its position, would turn on the erstwhile pursuer and drive it back into its own domain. I thought that it demonstrated the strength that comes from faith in one's cause, for I never saw an invaded bird lose its fight.

The singing persisted, the birds watched each other from opposite sides of the pool, and continued to defend their location, with constant pugnacity. The days grew longer, the water level lowered a little, the green of that aquatic plantthe mare's-tail-appeared and was followed by the shoots of cattails and the branching loosestrife. The reflections in the still waters had been brown all winter but now they were bright with the blue of the skies, the whites of the clouds, and the greens of the rapidly growing vegetation. Nest building went on, for the females had drifted into the marsh and the birds had begun to mate. I watched the nests appear all 
over the marsh. They were built usually in the upper third of the cattails or loosestrife, and in places where two or three strong upright stalks were close enough to permit lacing them together to make a substantial framework. They never appeared too securely fastened, but in the many years I inspected the marsh I never saw a wren nest out of place unless the whole plant structure to which it was attached had been undermined and brought low by storm. The nests were about the size and shape of a coconut, with cattails as the main material, lined with finer fiber and cattail down, and with a small entrance in the side, usually near the top. They were rather elaborate affairs for so small a bird to build, and I had always thought the weaving must have required much poking and pulling and careful work. It was two years ago that the sight of actual building changed my mind. In this case I saw one of the birds fly to a nest with one end of a long, narrow strip of cattail in its bill. It did not hesitate but moved in and out of the supports as a child might dance through shrubs with a string or ribbon in its hands. In a fraction of a minute it had placed the piece securely and had flown away for more material. I found much difficulty in watching them build for any length of time, for though they at first paid no attention they became increasingly uneasy if I remained and soon stopped work altogether. Some of the nests blended so completely with the surroundings that the casual canoeist would never see them, but a few, fashioned out of materials bleached by the weather, were almost creamy tan and could be seen from some distance.

When more wren nests appeared close to the original, it did not mean, as one might think, that the birds had waived their territorial rights. One nest would be the real one, and the others were dummies, built by the same pair. Whether this was done to confuse predators, or to satisfy the building urge of the birds, or in the hope that additional females might be attracted, I never discovered, although any of the reasons 
might seem, to some people, to be a logical explanation of this common practice of the wrens. One of the birds about the pool stopped when three nests were completed, but the other did not quit until four finished nests were closely grouped in its territory. I had always understood that the unoccupied nests were not lined with cattail down, but my faith in that theory was shattered when I watched a bird most of the afternoon as it carried and placed cattail down in three nests. If any tule wren had reason to omit placing down in its unfinished nests, it was this particular bird, a resident of a narrow strip on the south side of the marsh, for I found that it had constructed seven nests in its limited territory. This exceeded by three the most I had seen up to that time.

I timed the movements of one of the birds which lived on the edge of the pool. While I was present, it made six rounds of its territory, the longest trip requiring twelve minutes and the shortest, ten. Its path was not always exactly the same. Sometimes it flew close to the canoe and looked me over. It lowered its tail at the end of every burst of song, and raised it when singing was resumed. When I stood in the canoe, it moved back in the cattails. When I sat down so that I was almost concealed, it moved near enough to see me. Temporary bursts of curiosity often brought it very close. Now and then I could touch the base of the cattail on which it perched. But all of these short flights were but detours from the main journey as were its occasional trips to the lone, nearby.willow where it nervously perched and sang. It made sallies against any blackbird which alighted in the tree but without attacking-just expressing its displeasure by an unusual burst of song. The redwings, totally indifferent, moved only when they so pleased. The wren seldom flew to the top of a cattail stalk, but began singing about halfway up, after which it moved slowly upward and finally stopped just under the head or on the head itself. 
I wish that I might say something about the courtship of the wrens, but I must confess, though I cannot understand why, I have never seen any display connected with this most important event. Nearly all birds employ significant and sometimes very pretty mannerisms, and I am still hoping that I will some spring see the way in which these tiny birds make their courtship displays.

When the tempo of affairs about the nest slackened appreciably, I knew that the eggs had been laid and brooding had begun. During that time I saw only one bird at each nest and it spent most of its time singing from the high cattails. When the brooding period of less than two weeks was over and I saw both birds flying to the nest with billfuls of food, I knew that the family had arrived and the real work had begun. The thin voices of the young could be heard. All signs of family life appeared-as unmistakable as a clothesline full of diapers and a back porch full of milk bottles.

The broods were large, five from one and six from the other nest, but our wrens had little difficulty in finding food, for the cattails and loosestrife were so full of insects and grubs that feeding seemed only a matter of. transportation of easily secured material, of trip after trip with loaded bill. The comparative caution that marked the early stages of nesting was abandoned. The birds flew directly to the opening, entered without any preliminaries of approach, and reappeared almost instantly. The efforts of the adults never abated; the appetite of the young appeared insatiable. Their ability to consume this constant stream of food always amazed me.

This hatching period is the most hazardous of the bird life cycle. Many eggs are destroyed before hatching. Some young birds never live long enough to leave the nest. The nestlings are helpless. They face a multitude of dangers: the attacks of lice, ants, snakes, birds, and mammals. Injury to the parent birds often means the stoppage of food supplies. 
But even though predation is heavy the tule wrens hold their own, and I have seen no diminution during the many years I have been visiting the area.

Human predators, too, did their share of damage. So harmful was their meddling, even though innocent, that I would never look at, or work around, a nest if people were near. Failure to stop my work when a canoe went by once caused the destruction of a nest and its seven young, for the people came back after I left and out of sheer curiosity tore down and opened it to see what had attracted my attention. I can imagine their regret when they found it contained living young birds, but there was nothing that could be. done. Humpty Dumpty could not be put together again and so the nestlings perished. Our birds in the baylet were more fortunate for their nests were not among those which the raiders visited.

The season advanced. The quieter areas of water began to be filled with vegetation. Baseball and track teams occupied the athletic fields and their spring schedule was well on its way. The coxswains of the University crews rapped on the sides of the shells and called for a faster beat. Picnickers with baskets in their canoes left daily for various parts of the lake. The two families of wrens stuck to their area throughout all the activity. A second brood of young appeared and successfully survived. The young ones flitted in and out of their cattail forest. They picked, they scolded, they tried their wings, and they uttered thin immature cries as they perched and begged for more food from their overworked parents. The older birds became almost silent. Occasionally I heard bits of song but the enthusiasm and full repertoire had vanished. They did not occupy the cattail tops as in spring. They watched me from the shelter of some tangle. Autumn steadiness and wariness had replaced the carelessness of spring rapture. I missed the enthusiasm and discord which had so thoroughly filled the marsh. 
September came, the time for land and shorebirds to begin to leave, and the season when the marsh welcomed the influx of water birds. Already the mallards were scattered over the bay and soon the baldpates would begin to raft in the open water. One cold morning I nosed my canoe into the baylet. I saw no wrens. My friends had left, the lease had expired, the season for which the space had been reserved was over. From now on, mallards, fat from feeding on the knee-high smartweed which they love, would flush when I entered. They would be the fall guests of this part of the marsh. The stiff regularity of the cattail and loosestrife growth which held the wren nests would slump into a soft disorder.

I told the canoehouse manager that the wrens had left. "Where do you suppose they head for?" he asked.

My answer was quick, but only because I had checked it a few nights before.

"They go as far as Central America."

And that was the end of one lease in the marsh. Somewhere in a similar area between Seattle and Guatemala, nobody knows just where, will be the tule wrens, uttering their harsh chur, moving about in the marsh growth, and as much at home as when I watched them in their summer quarters in the shadow of the football stadium in Seattle.

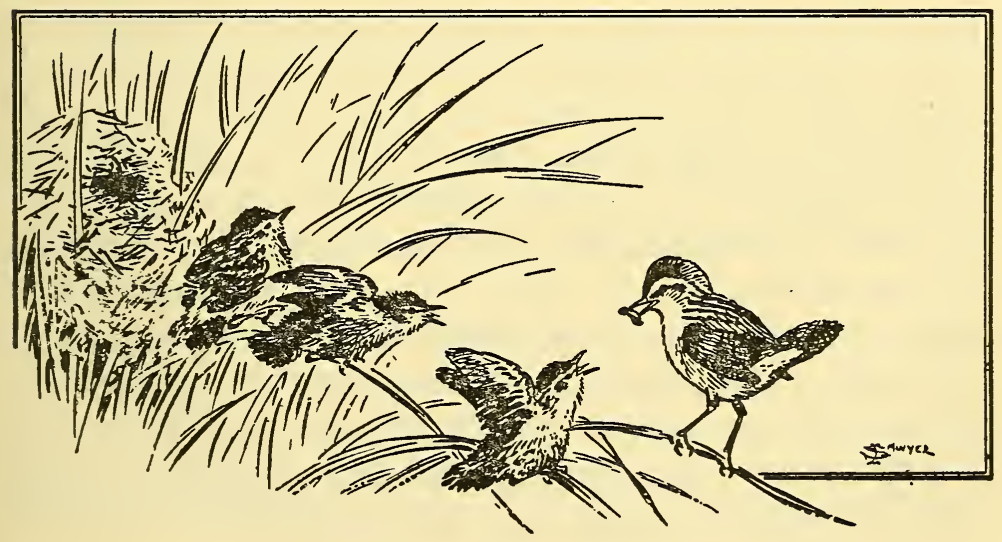




\section{The Marsh Is a Hotel}

3. the coming ANd golNg of the tule wrens served to emphasize what I had long thought-the marsh was not to be compared to a human village where the Wilsons, Smiths, and Browns married, raised children, grew old, and died, to be replaced by succeeding generations of Wilsons, Smiths, and Browns. There was nothing so fixed and static about this area.

Comparison of wild with human life not only is often unnecessary but is frowned upon by scientists because it imputes conscious design to creatures considered incapable of it. Of course the activities of the marsh cannot be exactly compared to human activities. But there is sometimes a value in superficial comparisons that not only entertain but bring about a quicker and more intelligent understanding. When I say that a marsh is a hotel, I do not imply the existence of expensive structures to be used for that purpose nor do I suggest that there is any kind of staff connected with it. But it must be remembered that one definition of a hotel is this: a place where transients may obtain food and shelter. If this interpretation is accepted, our marsh is certainly a wildlife hotel. It not only is adapted for the purpose but is constantly 


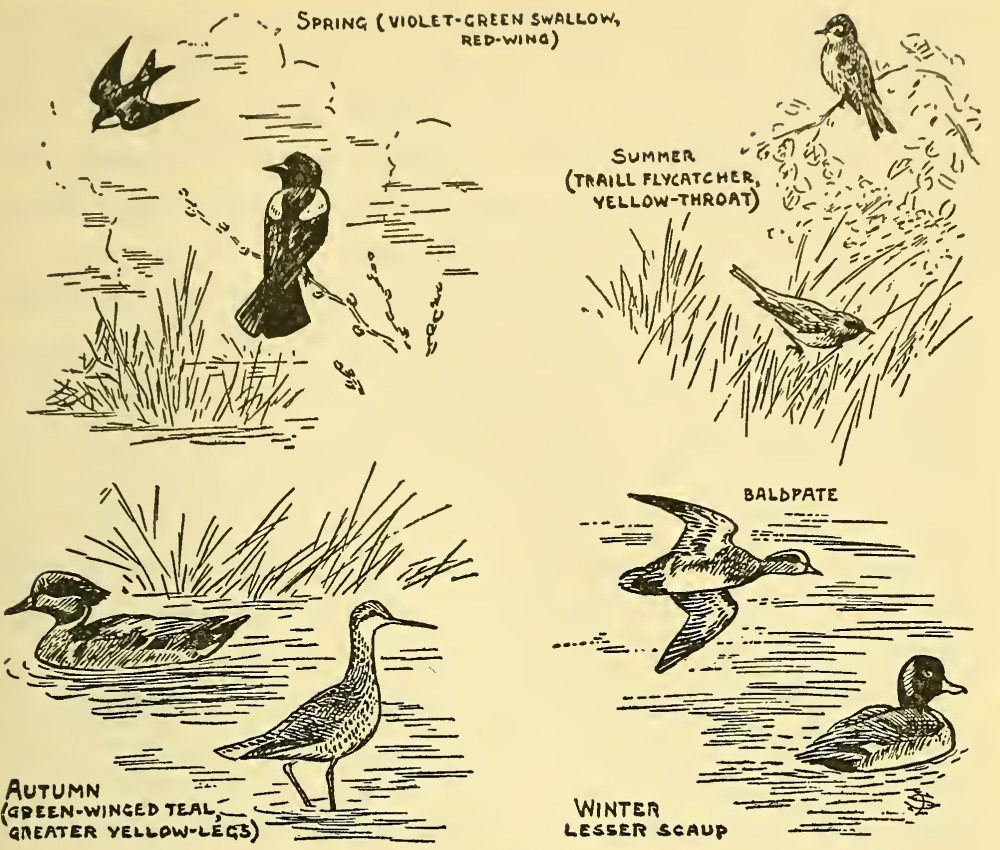

used for it. Guests come and go. There are several different classes. They appear at fairly definite dates and stay for quite regular periods. The tule wrens belong to one class of regular guests-birds which come to the marsh early each spring and use its facilities for nesting and raising their families, and when this is done return in late summer to the southern district from which they have come. Other species come to the marsh for this same purpose. And still others pass through in migration, or casually, or because they are storm driven. I venture the opinion that at least one hundred thousand birds annually visit the area.

The registry of birds visiting this marsh hotel is quite as definite and regular, I feel safe in saying, as that of any city hotel. And of course when I say birds, I do not refer to individuals, but kinds. There is no practical way of distinguishing individuals except by banding. For most of our 
purposes there would be little advantage if we could distinguish the individuals. What I mean to say is this: the different kinds of birds that visit the marsh do so regularly and make stays that are almost as definite as the two-week reservation which the Thompsons or Grays make at the resort hotel where they spend their vacations.

To those who do not realize the definiteness of the schedule on which nature operates, and who regard the presence of wildlife in any area as accidental and meaningless, this statement may appear of no particular concern, but it is of such importance in understanding the true position of a marsh community that I have gathered through more than ten years a rather detailed record of the marsh calendar and a register of the list of visitors which may reasonably be expected to drop in for an hour, a day, or an extended stay.

I have always regarded the marsh year as beginning on March 1. The months of January and February were never a rejuvenation as the start of a new period should be, but rather a tapering off-a time when the wildlife thinned out in numbers and species, a time when the marsh lay brown and dormant and showed no signs of new growth. The baldpates, American mergansers (mergansers are called fish ducks by hunters), scaups, and buffleheads among the ducks, and a few scattered species such as cormorants, coots, and pied-billed grebes could be seen now and then on the bay, but their numbers were small and they always seemed to me much like the stragglers around a summer resort' who stayed in late fall only because their apartments in town had not been vacated by their summer tenants.

That was not my idea of the opening of the year in the marsh. For me, it began logically when I saw the first tree swallows, blue-green backed and white beneath, flying over the bay. The earliest arrival date was February 21, the average March 1, and the latest March 15. They were the first migrants and they brought promise of activity to come and 
the hope that, regardless of the rigors of the past winter, spring would not be long delayed. Other birds would follow in rapidly increasing numbers. But the influx of other spring migrants was not immediate. The old saying that it takes more than one swallow to make a summer still holds good, for often many days elapsed before the next birds appeared. There is an old belief that the swallows and other spring migrants send out scouts to test conditions for the main body, but it has never been substantiated. However, the first birds often had a difficult time of it for the swallows of this area are insect-eaters and take their food on the wing. Lack of food frequently spells disaster for the aerial hunters. Sometimes we have had spells of bad spring weather for days at a time when the low thermometer indicated that few insects could be flying. Such weather always made me wonder how the swallows could successfully withstand such conditions, even though it has been reliably stated that tree swallows will take berries if insect food is not available. I have seen them hunting for insects even when sleet was falling, but I have never seen them-and my friends say the same-either eating berries or hovering about berry bushes as if preparing to feed. Perhaps in our district the weather is not cold enough to prevent the swallows from finding enough insects to prolong life. But prolonged storms certainly cause some fatalities.

These conditions brought few birds to the marsh but in the south many millions had become restless and excitable and filled with the same urge that sent the first swallows north. Every day thousands left their winter areas and began their journeys, some to go only a short distance, others, hundreds of miles, perhaps bound for places as far north as the shores of Alaska. They traveled routes chosen by their species, moving rapidly or slowly as is the custom of their particular kind, and flying singly or in flocks of various sizes. 
Among these birds were migrants which would pass over or stop at the marsh for food and shelter.

From the standpoint of marsh population there had been no increase in March. The gain caused by the arrival of a few swallows and tule wrens, and of a few redwings which displayed their red spots on their black plumage, had been offset by the loss in water bird population. The bay was bare of most of the ducks which had covered it during the winter. Only a few mallards, the green-heads of the hunters, and an occasional scaup, merganser, or bufflehead fed and flew about the area.

Nevertheless, a marsh room clerk, had there been one, could have scanned his registration list with some satisfaction. For though the occupancy was almost the lowest of the year, yet an active season was close at hand. I needed no room clerk to tell me what I would see in April. I had records of each of my trips to the marsh over a long period and in addition had made a separate card for each species, entering on it the various dates that I had seen it and when it had begun and stopped singing. Many birds came, and in close conformity to their previous schedule. I usually heard the song of the yellow warbler first and saw it inspecting the branches of a bare willow. Then another warbler, the yellowthroat, with a black band through its eyes, sang from the edge of the bank and flew back and forth over the cattails where I would find it throughout the summer. Redwings continued to appear and began their musical o-ku-lee almost as soon as they arrived. The marsh was now filled with tule wrens whose enthusiastic desire for singing pervaded the whole area. Strange and rarely seen birds came occasionally -birds that were not previously listed on my records, birds which I had not seen before in the area, and which I would not see again for a long time. The canoehouse manager continually called my attention to new arrivals. They would stay for a few hours, nearly all of them, and then they would be 
on their way again. Only a minute fraction of one per cent would remain, as summer residents of the area, and to mate and raise their young. All the rest were northward bound except a few, such as the varied thrushes, which spent the winter in the valleys and in spring flew to their nesting grounds in the higher elevations of the mountains.

In these days when the word "millions" is mentioned so often I thought it strange that little attention had been paid by the public to this migration movement which involves more than a billion living creatures. It is a remarkable example of natural logistics-this moving and feeding and sheltering of millions of birds. They must be provided with suitable nesting grounds and returned safely to their winter quarters. The operation involves four phases: the wintering; the trip to the breeding grounds; the courtship, mating, and care of the young; the return journey of the old and the young birds.

The operation must be precision-executed so that every detail will come off on schedule. The nesting must not be done so early that the young will hatch before suitable food is available. It must not be done so late that the growth and flight training cannot be completed before the fall storms. The return limits are therefore quite inflexible, especially in the districts farther north. Nothing can be left to individual chance: each bird must be filled with a stimulus which will give it the irresistible urge to leave the winter grounds and to start at the proper time on the long journey to the place where the courtship, mating, and reproduction are concentrated in one short season-a journey which, for a few birds, involves the length of two continents. Many of the birds which came to the marsh in this season wore breeding plumage, and the males, in particular, were brilliant and splendid in gay colors acquired especially for the occasion. The blackbellied plover made its spring passing in a formal black and white, and the horned grebe, gray and inconspicuous at other times of the year, appeared in rich and dark red plumage 
and tan ear tufts which have given the bird its name. Even the blue heron, which daily fished for frogs from a log near the canoehouse, added some long white plumes to its somber gray suit, a striking concession to the importance of courtship apparel.

Certainly this spring migration and nesting ground period was the most satisfying of the year's experiences for the birds. Spring shooting was no longer a hazard now that public opinion had banned it. The storms which came up, though severe, were soon over. The days lengthened, the feeding conditions improved, and the instinct that drove them toward the nesting areas must have eliminated all sense of minor discomforts.

There was little opportunity to observe these restless travelers. If the water was high the shorebirds did not stop at all for there was no food available. Birds came and went. Sometimes I would see them alight in some section of the marsh and then rise in a few minutes and be on their way again. If I flushed them at other times of the year, they usually flew to a different portion of the marsh but, in spring, if they went into the air, they generally left the marsh entirely. And so the migration went on, not easily discernible except to one who watched it closely, with the marsh playing an apparently insignificant part until one realized that it was only the united contributions of thousands of such areas that made this enormous transportation task possible.

Rushes and cattails appeared and were now álmost waist high in the deeper water sections of the inlets. Yellow iris bloomed, the carp began to spawn, the marsh colors suggested the sweetness of late spring, and of the cottonwoods and the growing herbs and shrubs. The elderberry bloomed. Nest building had been completed by the tule wrens. The migration tapered off in early June, the tree swallows having led it and the nighthawks being the last arrivals.

After the middle of June, the marsh register dipped again 
as regarded new arrivals, but hatching boosted the population considerably. I continually heard the thin notes of young birds-blackbirds, tule wrens, grebes, killdeers, flycatchers, and warblers. Insistent were their calls for food, and indefatigable were the efforts of the parent birds to fill the gaping mouths.

This marsh concentration on domesticity was temporary. August had only begun when the canoehouse manager called and said that the first returning migrants, the yellow-legs, had arrived. He had heard their mellow voices. From then on, previous experience told me that I could expect many guests. I had long since realized that the resident birds were not responsible for the activity of this wildlife hotel: they amounted perhaps to fifteen per cent of the total registered species, and, of course, to only a tiny fraction of one per cent of the total number of visitors. If I continued my comparison with a city hotel, I could say that the marsh had an extremely satisfactory clientele which, instead of filling it for a twoor three-month nesting season, spread the patronage over the entire year in a regular spaced coming-and-going which would have pleased any hotel man. From the standpoint of an observer it simply meant that he would find it interesting at any season of the year. I thought it particularly attractive in late August and September. Then green-winged teal, pintails fast and trim, wood ducks with their unsurpassed greens, reds, and grays, and a few dingy coots replaced the departing summer residents with a different but equally active guest list. As the weeks went by the increasing acceleration of departures was offset by the newcomers, and soon the marsh had lost all of its summer residents except a few mallards, bitterns, rails, and song sparrows which remained to winter.

The date of arrival of the fall migrants varied some from year to year but the order of arrival of the different species remained surprisingly constant. I discovered that the green- 
winged teal were always among the first to get here and that small migrating shorebirds came soon after if the lake level were low enough to expose the flats where they fed.

The returning birds and their young differed in many ways from those I had seen in the spring. Their summer had been filled with most of the things that can befall a bird. They had paraded and displayed their finery on the breeding grounds, had mated, built their nests, and tirelessly looked after their young. They had been helpless against a predation which had possibly taken half of their little brood. They had trained the remainder in the ground ways of their kind, and had prepared them for the return journey, which must be begun within a few weeks of their hatching.

When the black-bellied plovers had passed through in spring, they showed the impatience of salesmen waiting for the next bus, but on this return trip they fed, warily and at a distance, for a week before weather conditions sent them on the leisurely way again. If the birds had operated by the clock in spring, they now seemed governed by the calendar. Their appearance was different, too. The color of the plumage was more sober and its freshness dimmed. The formal black and white of spring had been replaced by an inconspicuous gray which transformed the dandy into a colorless and dowdy plebeian.

I watched these returning migrants with interest and, I must confess, with some concern, for I knew the many hazards of the remaining phase of their migration cycle. If all went well they would complete their return trip without undue hardship, but many pages of records testified to the dangers of these annual trips. I had seen ocean birds driven far inland by storms and had found the bodies of many which had perished, and I knew there was always the threat of insufficient food supply, attacks by predator hawks and owls, oil pollution, lead poisoning, caused by picking up shot in gravel-a source of many fatalities in much-hunted areas 
where the pellets had accumulated for years. There was the fatal attraction of powerful beacon lights. Widespread natural catastrophes killed many: I recall the classical examples of the sleet storm which destroyed hundreds of thousands of snow buntings and of the tremendous loss of passenger pigeons in a prairie storm, a loss so great that it certainly hastened the total disappearance of this bird from the American scene. And the wildfowl had the gantlet of man's destruction to run. But though the losses might be high I saw no evidence of fear or nervousness among the birds in the marsh.

Each fall I watched this arrival and departure of returning migrants. It was only a microscopical section of what was in effect an amazing transfer of whole wildlife populations for some not-too-clear purpose. The birds came through singly or in very small flocks instead of in the thousands that followed the main flyways. I speculated on the causes of this annual movement and read the many attempts to answer, none of which has been completely accepted. The most favorably received idea attributes it to the necessity of leaving the northern territory during the cold winters of the glacial age, but that had been at least ten thousand years ago, and why should the habit persist so strongly through the changed climate of centuries that it would still bring tiny western sandpipers from northern South America to Alaska for the purpose of mating and raising their young, a stay which occupies only about a quarter of the calendar year? The common tern nests as far north as British Columbia, then winters as far south as the tip of South America. The tiny rufous hummingbird plays about the marsh in summer and is seen in Central America after migration.

Why such tremendous trips? Food is said to have been an important factor when the ice advance had blocked off much previously available land. Many hold the theory that birds go south to the lush wintering spots only because their 
favored northern habitats cannot support them at that time of year. They return when these places are again fruitful. Light is thought to have an important part in stimulating migration-the birds undergo physiological changes due to the lengthening days and finally set off as a result of that stimulus. But this theory does not explain why birds migrate north from south of the equator when the days in that locality are shortening and not lengthening. Elaborate experiments continually test the validity of the different theories. The exponents of the light hypothesis have shown that a bird detained beyond its usual time of migration loses the desire to migrate, and that by placing a bird in artificial light and increasing the amount each day the date of migration can be hastened. Someday more may be known about the nature of the causes which produce these tremendous effects.

In the fall and winter, the marsh register showed a continuous change in number and species of birds. The permanent guests-a bittern or two, some Virginia rails, a few song sparrows, some towhees, and usually a few pied-billed grebes -were silent and unobtrusive, and only the gulls made their presence known by crying loudly and fighting for the food that one of them might discover. They spent much of their time at the sanitary fill at the north end of the bay while the other birds clung to the marsh margins where the lodged cattails made pockets and tunnels which provided shelter.

It was not the season for upland birds, and the transients, shorebirds excepted, confined themselves to the open waters of the bay and channels. Ordinarily, the different species did not mix indiscriminately, although there were times when I saw canvasbacks, pintails, mallards, scaups, and coots spotted among the baldpates like black sheep in a flock. Incoming birds came to that portion of the marsh which they liked and there they stayed. If there were mergansers I usually saw the larger species near the log rafts or on one of the logs from which they would slip when disturbed so they could 
launch themselves from a liquid instead of a solid base. The dainty hooded mergansers, with heads patterned in black and white, preferred the quietness of the channels. I would find gadwalls in Gadwall Cove. The mallards dabbled and fed in the shallow water along the marsh margins. It was a surprisingly precise arrangement: each species following its own desires, each portion of the marsh occupied and used by birds which liked it-a bird for every habitat and a habitat for every species-and usually a quite definite time for each species to make its appearance in the marsh so that I easily could have constructed a map showing the approximate location of the different birds, and also a table indicating the approximate period for which they would be there. Such a schedule would be subject to changes but probably little more than the unexpected cancellations and changes of plans which would have upset the reservation records of a city room clerk.

With the approach of winter certain species almost, or completely, disappeared. For example, I noticed that the red-breasted mergansers were fairly numerous in late October, but by the first of the year few were left and American mergansers had come in. Scaups arrived late but stayed well into spring. Wood ducks and pintails came early and were seldom seen after the middle of October. The register changed so that almost always when I made a new list I would remove a bird that I had recorded on my last trip and add a new one that had just come in. This made a constant shifting which, though gradual, greatly changed the character of the list every few weeks.

January and February, the beginning of the calendar year, closed the marsh year. The few birds that came in probably were stragglers, or storm-driven waifs, and not part of the regular marsh movement. On the other hand, the constant shrinkage in numbers was a regular and expected part of the schedule. Since the preceding February the area had 
discharged all its functions as a wildlife hotel: the providing of food and shelter for the marsh community itself, for the permanent residents, the north- and south-bound migrants, the summer-nesting birds, and the many casuals and stormdriven visitors. The quiet of January and February was but a prelude to the activity which would begin again in March. 


\section{The Tail Slapper}

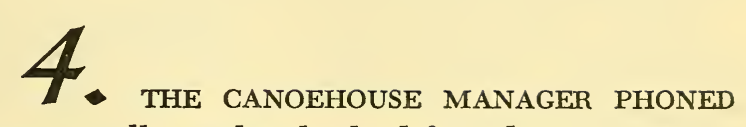

one April evening to tell me that he had found my exposure meter in the canoe I had been using. After dinner, I drove down with the intention of returning immediately for I had already experienced a pleasant day on the water and was a bit tired and willing to rest and read. I stood and talked with the manager and then found myself sitting down to enjoy the quiet restfulness of the evening. I watched the canoes come and go. The variation in skill of the paddlers interested me. Some handled the canoes easily, while others indicated by the clumsy way in which they embarked that the canoes were almost never used by them. Before I knew it, darkness had almost slipped in. The airplane beacons in the Cascades had begun to flash and we saw them clearly on three peaks. The power boats displayed their lights, and the highway was bright with the gleam of passing cars.

The water was in shadow and we could just see the motion of an animal as it crossed the bay.

"It's a beaver," said the manager. "A good many canoeists have enjoyed them since the year we first saw them. They are the big attraction of the marsh." 
I could hear the faint splash of its dive, then all was quiet. As I returned home I recalled the first appearance of the beaver in the bay. I had never expected to see this animal in a city area such as this. I had always thought of beavers in terms of remote lakes and streams, where hardy trappers, constantly menaced by hostile Indians, had undergone danger and hardship in search of the animals. I knew that a few beavers, probably from somewhere high up on a mountain stream, had been reported in certain parts of Lake Washington. But the thought that they would be seen in a city as large as Seattle struck me as nearly impossible. Some years passed before it was proved otherwise.

While I was following one of the canals in spring several years back I had approached a newly fallen tree. It was not an unusual sight, for the grounds force often removed one to prevent crowding, to widen a path or road, or to improve the view. But there was something about this tree which attracted my attention. Neither axe nor saw had leveled it. There was no mistaking the hourglass cut which had brought it down. The eight-inch trunk of this cottonwood had been cut at an even angle both from above and below, whereas, had an axe been used, a long angle from above would have met an almost square cut beneath. The sharp lines of good axe work were missing, the cut showed the uneven marks of teeth. I had not seen the animal which did it, but the condition of the tree told me that a beaver had been in the marsh, and that it might be there still, for the cut was new and the leaves of the tree fresh and unwithered.

I knew quite a lot about the beaver. What resident who was acquainted with the early history of the Northwest did not? I had studied it in the laboratory and knew where, in the scheme of things, science had placed this highly specialized animal. I knew its dental formula and how it could cut down five- or six-inch trees in almost as many minutes. I had seen it now and then on mountain streams and had run 


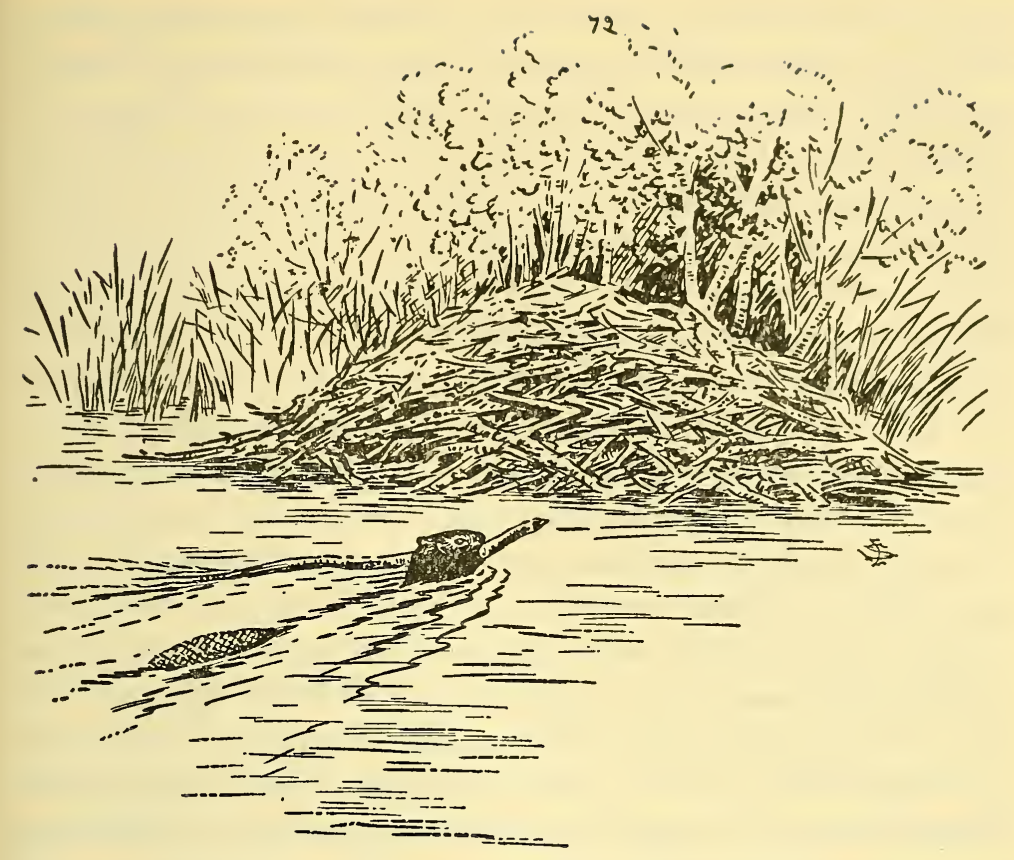

across old beaver dams in many places. The mere sight of one would not have excited me, but I must confess that the thought of the largest of our North American rodents visiting our little marsh gave me pleasure. People, buildings, human activity, and noise surrounded the area. Yet, on the bank before me, was positive evidence that an animal feller-oftrees had been working. It had stood near to where I sat in my canoe and, balanced on its large webbed rear feet with its tail as a third point of support, had used its chisel-like teeth to bring down the tree. I looked to see if others had been attacked but there were no signs. The woodcutter was a new arrival.

Once, a quite similar species, the Old World beaver, could have been found in large numbers in Europe, Great Britain, and the colder regions of Asia, but everywhere they had 
been closely trapped and now remained only in scattered locations and in small numbers. Paleontologists had discovered the fossil remains of an ancient beaver as large as a bear. The smaller modern form had been known to the Greeks, and Pliny, the Roman, had written about it. Once, the American beaver could have been found over practically all the wooded parts of the United States and almost to tree limits in the mountains. In the early days of this continent's settlement, furs were in demand everywhere and could find a ready and profitable market. Beaver skins-smooth, silky, warm, and enduring-were used for garments and hats. When the white people came, their desire for furs was the cause of sending out their own men and Indians as trappers and killers of these peaceful creatures. The search for them, which spread into the most remote districts, had much to do with the discovery and settlement of the West. Many of the men whose names rank high in the history of western exploration followed the trails of trappers and traders who, alone or in small bands, had pursued, regardless of difficulty, any route which would bring them to the lodges of beavers or the wigwams of the native tribes who trapped them.

As I read the history of the Northwest I marveled at the part played by the beaver. The Hudson's Bay Company, greatly concerned with beaver pelts, had maintained a system of widespread establishments of various sizes in order to keep in touch with ail geographic sources of supply. Its greatest rival, the Northwest Fur Company, directed the bulk of its energy to the same fur. Many Americans entered the trade. A few made a success of it.

Never has the name of an animal been so honored. It was given to the first steamship to operate on the Pacific Coast, to several towns and cities, to rivers, creeks, lakes and ponds, to waterfalls. The quarterly magazine of the Hudson's Bay Company is called the Beaver, the annual fur sales of the company have been held at Beaver House in Trinity Lane, 
and in Montreal was founded the famous Beaver Club, a group of men in the fur trade whose initial requirement for membership was that the applicant had wintered in the Northwest. Oregon, in the early stages of its history, issued coins bearing the picture of the fur bearer and called beaver money. Indian folklore is full of stories in which the beaver is represented as wise and powerful.

I visited the area about the fallen tree every time I was in the marsh. Most frequently I went in the morning but whenever possible I tried to arrive in the evening as I knew the beavers were largely nocturnal and, in places where they might be disturbed, seldom ventured out in the daylight. Though I did not see them I took encouragement in the fact that here and there I saw evidence of their work-a cut sapling, a few branches floating in the water, or a section of small log which obviously had been towed along the canal. I usually left the canoehouse with rather high hopes, but when I had passed the sailboats and cruisers in the canal, and had been waved at by the passengers on the excursion boat which daily ran between Lake Washington and Puget Sound, I would begin to ask myself how I could expect to see a native of the wild in such completely urban surroundings.

The more I looked for the animal the more it interested me. This was the engineer that built dams across moving streams and used the water thus impounded for its own private lake where it would be safe from the attacks of most predators and where it could easily transport its food to its lodge. As a resident of a forest country I knew how much a $\log$ pond saved a sawmill in the cost of handling its saw logs, and I could see the great advantage which water transportation gave to animals that would otherwise have to toothhaul their food by sheer strength and over rough and often hilly ground. This dam building was no occasional device used by only the old and the wisest of the animals. In the 
Rocky Mountains, I have seen whole valleys whose surfaces have been leveled by the work of beavers. They have built dams which have been silted up by the spring freshets, and when they are useless the animals have built more, a continuing process which has resulted in the construction of flat and fertile valley floors.

The threefold virtue of the dams-to provide protection, $\log$ transport, and house sites-is quite evident. The deep ponds enable them to build island homes where entrance from below is always possible even when there is surface ice. Easy towing of the floating wood is certain and the soft ooze of the bottom makes possible the sinking and anchoring of the winter feed, which is pushed into the ooze or covered with mud or rocks as required. The beavers stay snug under the frozen roofs of their lodges in winter and as secure from the attacks of predators, except man, as it is possible for such animals to be.

There is an island about three times as large as a tennis court which was formed by the turn-around of the dredge when making one of the channels of the Arboretum. I had seen a green heron fly from the trees covering it and, as I hoped it might be nesting there, I looked for it on every trip that I made. I had just reached the turn one afternoon when I heard a slight sound which, when checked, proved to be made by a large mammal swimming toward shore. I knew that it was much larger than a muskrat. Its head was shaped wrong for an otter and it did not swim like one.'The canoe alarmed it and as it dived its broad tail slapped the water with a noise as loud as could be made by the broad side of a canoe paddle. The channel was narrow and the beaver did not reappear but I did not care, for I knew that it had taken up a more or less permanent abode and that I would see it again. The island itself and the north shore offered many real advantages and I hoped that the animal, or animals, would remain in this altogether desirable spot where visitors on 
shore seldom came and the entrance of which was blocked with enough aquatic vegetation to shut out most canoes.

I had always heard that aspens and willows were the favorite food of the beaver, so I expected they would be attacked first. But apparently the reporting scientists had not seen beavers exposed to silver poplars, for in this case their diet preference was for poplars to the exclusion of all other trees. When I came around in four days one of the trees was down and half the branches had disappeared, which led me to believe that there must be at least a pair of beavers to make such progress. As it appeared quite probable that the animals might confine their attention to this little island, I checked and found that it contained a few willows and twenty-seven silver poplars, eight or nine inches in diameter, thirty to forty feet high, and as bushy and thrifty as could be desired.

I would have liked to watch the beavers begin the construction of a dam and lodge. I knew the water was deep enough for the transportation of their food supply, and the shore was high enough to permit construction of burrows. It was a bank-beaver location. I wondered if the animals showed any preference for bank sites. In such areas they would be spread out to prevent easy trapping, while, in lodges, the concentration was such that the early trappers, once they found such a location, seldom left until they had cleaned out the entire colony.

If the removal of island trees was any indication, the marsh population of beavers (one to ?) prospered. Every few days I noticed that a tree had been felled, cut up, and pieces removed. Trees on the margins went first and soon the place had a shorn look quite different from the comfortable roundness that had formerly covered it. Although I seldom saw the animals, the disappearance of the trees and the short troughs made by the hauled material plainly indicated the speed and method of operation. My suspicion that they 
had constructed a home in the canal bank opposite the north end of the island was confirmed when a temporary lowering of the lake revealed a couple of good-sized tunnels running into the bank. I wondered if there were one or more pairs, but, although I watched closely, I saw no young and never more than one mature animal at a time. The rate of disappearance of the trees made it certain that more than one animal was present, so I always approached the spot with the hope that I might see several together. As is common with all mortals, my hopes increased with my accomplishments. I wanted to see them at work, to watch them and their young as they went about their daily life.

It was not because I thought I could add any information to what was already known about the beavers. They had become so tame in some protected areas that they often worked in daylight where they could be studied by any patient and interested person. Intimate details had been learned: the myth that the tail was used as a trowel for plastering had been disproved, and it had been discovered that this heavy spatulate appendage found its principal employment as a rudder, as a support for the hind legs when cutting went on, and as a signaling instrument when danger appeared. Although it appears difficult to believe, it is reported that the animals are able to submerge for periods up to fifteen minutes. The trees are felled haphazardly and not, as frequently said, laid down in a predetermined position as would be done by a logger. The choosing of dam sites showed so little skill that rebuilding at a more favorable location was often necessary. Dams were seldom much over five feet high and few, if any, reached the fifteen or twenty feet reported by legend. Mud for the plastering of holes was not carried in the mouth but in the clasped front legs. The contents of the musk glands, once thought to be of great medical value, had been discredited by research, and were no longer used by reliable physicians. 
I saw only a few things to add to these detailed observations. The fact that the little grove of silver poplars was on an island had given me an opportunity to watch the exact speed with which a specific area was denuded, but it was a matter of interest rather than scientific value because I could only guess at the number of animals employed at the work. I had read that the animals did not remove cut pieces over five inches in diameter but either peeled them on the spot or left them untouched. On the island the beavers left no pieces even though some of them were eight inches or more in diameter. It may have been because they were particularly fond of this silver poplar, because food was not plentiful or because these trees were so close to the water that no great problem of overland transportation was involved. I had read that the favorite food of the beaver was the heavy root stock of the water lily, but in spite of its comparative abundance I saw no indication that the plants had been raided or fed upon to any extent by mammals.

I had visited the spot one or two times a week. The number of trees on the island steadily decreased until I began to wonder what the animals would do when the supply was exhausted. The cattails matured and the heads began to burst and scatter their seed. The mallard young had grown to be as large as the hens which raised them. At last only five poplars remained in the center of the island. They had been disappearing at the rate of a tree every six or seven days. The fresh greenness of the island had vanished. Before, from every side of the island, I saw leaves moving in the breeze and showing their undersides so that the whole effect was one of metallic whiteness. But the bare spots had been taken over by nettles so that, if I landed, I wore an old raincoat and a pair of leather gloves to avoid the unpleasant sting. When I returned ten days later I found only one tree standing. The other four had been removed at a rate which far exceeded the previous average. Could they have been har- 
vested for winter use? $\mathrm{Had}$ the place been visited by another group? I could find no place where the pieces might have been placed in storage, nor did I find any floating logs in the canals.

Contrary to my expectations, there was no great change after the last of the silver poplars had been cut. I noticed that willows had been removed in places along the canal but not in quantities as impressive as the cutting on the island. Whether some of the beavers had moved when the food supply on the island gave out or whether they still remained was something I could not determine. Some of them certainly remained, for now and then I heard the slap of a broad tail and if I turned quickly I could watch the dive of the animal I had disturbed.

Some years after the beavers had cropped the island I took a winter walk which carried me past a section of marsh canal. I had not inspected the area for some time because dumping of dirt from basement excavations on the campus had blocked the canal enough to prevent the passage of my canoe. The place lay just outside the fence of the football stadium. As I looked at the ice-covered channel and at the trees on the other side my eyes were attracted to a heap of loosely piled logs about six feet high and fifteen or twenty feet in diameter. It could only be one thing, but it seemed impossible that this pile could be what I thought it was. I looked at it closely before making my decision. It was not a mass of miscellaneous pieces dropped there by a dredge: there was a regularity in the piling and in the size of the pieces. Through my glasses I inspected the way in which the ends of the pieces were marked. There was no doubt about the structure. It was a beaver lodge.

I had always been glad to see a beaver lodge in the mountains, but I felt that I had received the ultimate from the marsh when I looked at this dome-shaped pile of logs, mud, and vegetation. I wondered whether there was a supply of 
food under the ice or whether there was an exit which led to open water on the bay side. Near me were some cottonwoods which had been protected by a three-foot band of wire netting placed there by those in charge of the University grounds. Such protection was badly needed, for one, poorly wrapped, had been attacked just above the netting, and the tree lay on the ground. It told me two things-beavers were still about, and they were not depending entirely on stored supplies.

It had snowed the night before and there were no tracks but mine. Toward the lake there was a short stretch where I could see only smooth whiteness, the ice on the canal, and the rough-covered dome of the beaver lodge. Under the stimulus of such circumstances I had never been able to concentrate on the present and ignore the past. I thought of the many thousands of these lodges which had sheltered the beavers from wild predators and the occasional raids of Indians who took them only for their own use. Food had been plentiful, and there had been no competition for the trees which they used for dams and lodging. The thousands of colonies flourished. The invasion of the white race had changed these things until finally the beaver had nearly disappeared.

For years the beaver was considered as almost a vanished animal. All talk about it was in terms of its past. But the lodge in front of me slightly changed the picture. Was it possible that the animal might make a comeback? Here was a colony within a city block of a modern stadium. The absence of trapping pressure had made them indifferent to man and his civilization. If beavers could exist within half a mile of district service and commercial clubs, was it illogical to think that, in the future, the animals would again be seen in large numbers? The thought had pleased me and, at the same time, appeared possible.

Then I remembered the remarks of a professional mam- 
malogist when we had discussed the beaver a year or so before.

"The beaver is coming back without a doubt," he said. "And it's going to be a regular headache."

"Why?" I asked.

"If there ever was a contradictory character among the mammals, it's the beaver."

"For what reason?"

"Look at its record. It's like having a wonderful cook and housekeeper who steals all the silver. It is one of the greatest factors in the control of floods and the conservation of water supply. It is a soil maker and a builder of farm lands. We just can't get along without the beaver."

"What is the complaint, then?"

"There's another phase, the silver stealing."

"You aren't saying that it leads a double life?"

"It certainly does. As long as it stays where it belongs it has a perfect record. But a species with its habit of wandering and colonizing can move up and down a stream and stop wherever it finds a good location. When it stops it begins to change things. And the kind of changes it makes can cause a lot of trouble in some spots."

"For example, what spots?"

"Around valuable lowland lumber regions, fruit trees, and in well-developed residence districts along lakes and streams. In such districts they have been known to cut down trees that could not be replaced for several hundred dollars. They keep railroad maintenance crews busy by damming small culverts and bridges in some locations."

I had thought little about it at the time, but after watching the island in the Arboretum, I now realized that the rapid increase in beavers would make a real problem for conservationists and game managers. The mammalogist had been right. Men will make the sacrifices necessary to get along with many creatures and will not begrudge a reasonable 
share of the cherries to the robin, a few fish to the kingfishers, and some young pea plants to the pheasants. But these demands are as nothing to those of the beaver. The robins ask for part of the fruit of one tree, but the beaver asks, not for a little fruit nor for any particular part that can be removed from the tree without injury, but, in effect, for the whole tree, for many trees-and, as my marsh experience showed, sometimes they take the whole grove. Often these groves represent much of the lifework and wealth of the owners. The silver poplars in the Arboretum had been carefully planted and nurtured. The grove was a lovely thing. Would tree lovers be willing to continue to donate such clumps for a half-year's support of a colony of beavers?

The beaver, like the wolf, was unlucky enough to run smack into man's dollar. Its demands were too great to justify its existence within many densely populated districts. It must have food and since this food was largely parts of trees obtained only by the destruction of the tree, it was obvious that it would not be tolerated in cerain areas. In a place like the marsh and in small groves, trees could be protected by putting a wire screen around the base, an inexpensive and simple operation. This is not practical in large areas because of the expense and patrolling required. Neither is it any answer to the problem of retaining the beaver in the locality, for if every tree within its reach is protected so that it cannot be cut, it will hardly be possible for the beaver to continue to exist. The problem has already risen in the state of Washington, where beavers have attacked orchards, valuable shade trees, and where they have constructed dams which caused flooding. To date, the difficulty has been met usually by the transportation of trapped animals from places where they are not welcome to places where they are needed, but in some cases it has been found necessary to trap and pelt the animals.

As I walk or canoe about the marsh I realize that the bea- 
vers are facing almost insurmountable obstacles. Although nearly everybody likes them, nobody is willing to pay the price for their support. The desirable trees near the water are netted, the less-favored ones are disappearing. Many of the trees in nearby residence districts are being protected. It is quite unlikely that the available trees will support more than a few pairs of these animals, yet if a pair is around they will multiply.

Under that harsh unwritten human law which says that the existence of the so-called lower animals must be subordinated entirely to the needs and wishes of man; there seems to be only two means of tolerating the increasing beaver supply. One is their limitation to the back country where they can do no damage and where conditions favor them. The other lies in the possibility that they will modify their diet and get away from the shadow of the dollar by relying completely on the waste products which it is said they now eat when trees are unobtainable. I had always considered such diet flexibility extremely improbable until Nature Magazine recently published an article in which the well-known biologist, Dr. Victor B. Scheffer of the United States Fish and Wildlife Service, expresses the opinion that in the semiarid conditions of eastern Oregon “. . . the animals [beavers] will, if necessary, exist comfortably on a diet of aquatic grasses and willows."

Important as this observation is, it is overshadowed by the statement: "The beavers soon establish a condition of "sustained yield,' the goal of the professional forester." In elaborating, he says:

Judging from observations, a colony of beavers may establish such a relationship with the willow vegetation that as fast as the bushes are consumed or destroyed, a like amount of new vegetation grows up to replace the loss. While no one would seriously suggest that the beaver "plans" the sustained yield program, the end result is the same. 
It is a cheering conclusion and one which it is hoped that the future will confirm. To feel that not only will the beaver be able to get along in certain places without depending upon valuable trees, but that it will actually set up conditions which will produce a continuance of supply of the products upon which it can subsist, is to help to provide a solution to a problem which has heretofore seemed almost unsolvable.

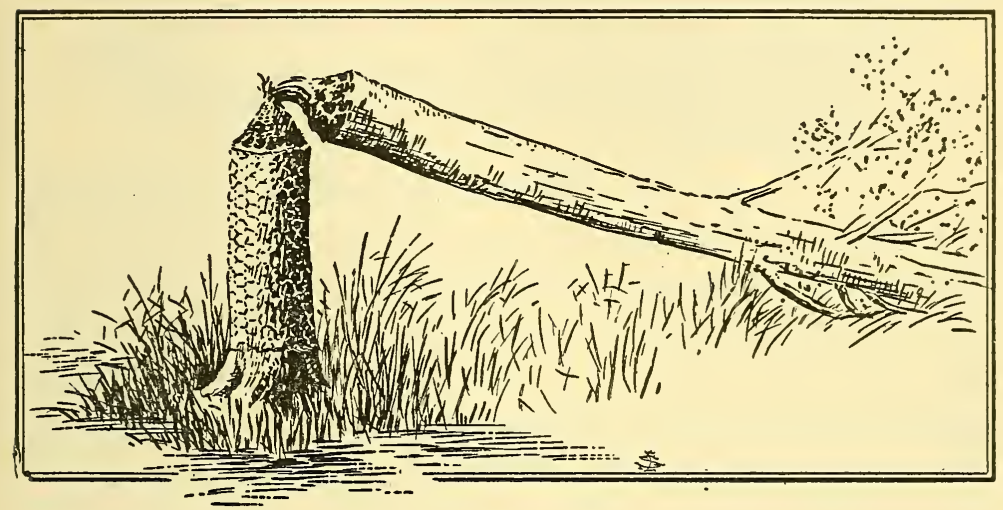




\section{A Worm's a Worm}

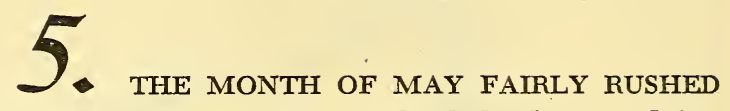

in. In the Cascade Range the snow line which had moved far down the mountain sides during the winter now crept dispiritedly back toward the summits. In the marsh, warm days stimulated the tempo of living things so that the foliage opened, the buds burst, and the birds sang continually. Strollers discarded coats and appeared in shorts. Tennis players stripped to running pants and prepared to take on a tan. Boats congregated in Canoehouse Bay. The freshness and sunshine so effectually beckoned to the fishermen that I knew wherever I paddled I would see them in boats or on shore.

During this spring rush, in order to avoid the confusion, I usually got out of the inlet before the fishing craft appeared, and especially before the University canoe classes filled the float with a score of canoes and twice as many girls. They were invariably a little late and all tried to get their canoes into the water at once. But on that particular morning the small bay held many boats, each carrying one or two fishermen who concentrated on the serious job of watching rods and lines. The anglers talked but little although they 


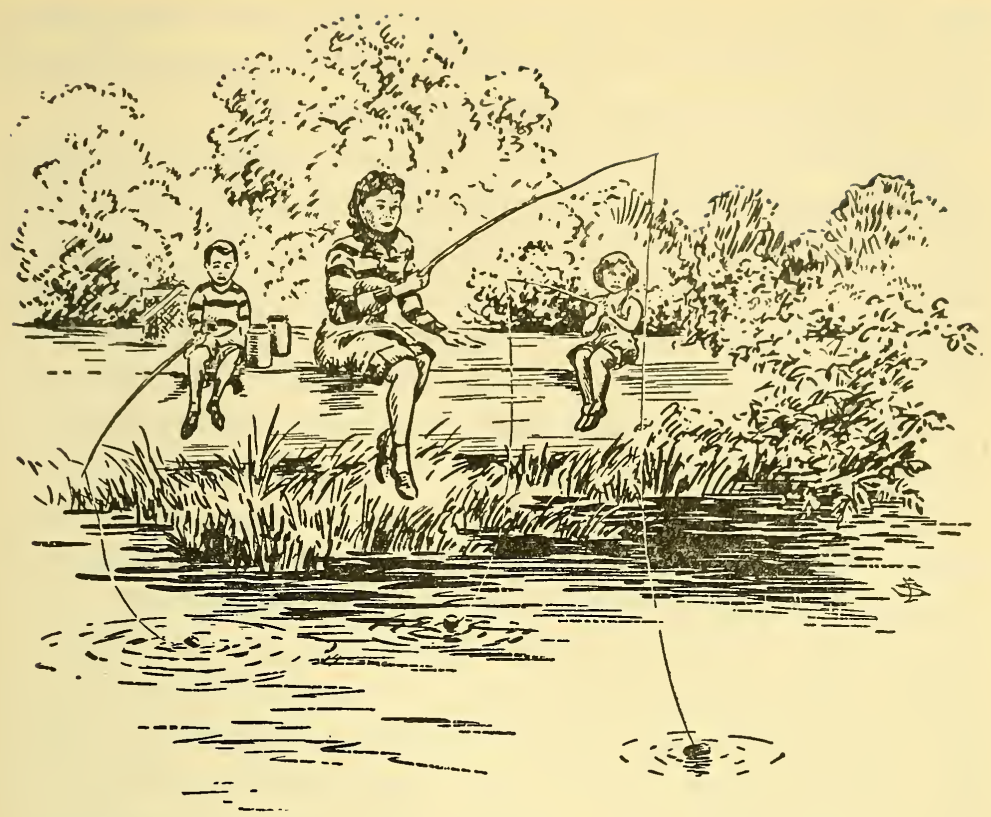

had moored close to each other. The canoehouse manager had fished before the crowd arrived, and when I got there he was standing near the outside water tap with a nice catch of perch and crappies neatly spread out on a white cloth. They had all the beauty of new-caught fish, the blue on the crappie gills still undimmed and the scales of the perch standing clearly and brightly in the morning light.

"Are they getting many?" I asked. As a noncompetitor I could ask questions which would be truthfully answered.

"Some are and some aren't."

"I wonder why."

"Just like everything else. Some people don't seem to have any trouble. Others can't make it even if they borrow the other fellow's rod, boat, and bait can." He laid a fish on its side on a short piece of plank and fastened it lightly with small nails through the head and tail. "It's funny about fish- 
ing. A worm's a worm and a hook's a hook but some fellows can do ten times as well as others with the same outfit and bait. Somebody else will have to explain why."

He picked up a fish scaler of his own making, a ten-inch strip of wood fashioned into a handle at one end, with three beer bottle caps attached in the form of a small triangle at the other. He scaled the fish rapidly, the rough edges of the caps removing the scales with remarkable efficiency, the nails holding the fish firmly in place. As soon as the fish was smooth and the belly cut made, the nails were pulled and another fastened.

I remembered the ordeal of cleaning scaly fish when I was a boy. They were slippery and we tried to hold them with our hands and scale them with a kitchen knife, a job so unpleasant and difficult that only the prospect of the delicious meal to come would keep us on the job. I thought, you can't tell a real sportsman by just watching him handle a rod or gun; there is a lot more to it than that. There is the way he prepares his fish or game, handles his pack, fixes up his food list, picks his camp site, and meets bad weather conditions. Everything that I had seen this man do showed that he was an expert in the field.

A commotion in one of the boats made us look up. An old fellow, comfortably leaning against a chair back bolted to the seat, had just caught and netted a nice fish.

"There's a fine one," my companion said. "That old boy has them all beat. His fish will weigh a pound and a half. Look at the other boats crowd over to where he is. They act as if there is a well under his boat and all the fish in the lake are in it. But I guess if business is good you can't keep out competition." He finished scaling the last fish and rapidly cleaned them. Then he got out a canoe for me.

The sun was now high enough to warm things considerably. A surface haze caused distortion which made the coots and pied-billed grebes look as if they were swimming six or 
eight inches above the water. Even the ferry crossing the lake had the appearance of riding on a platform a few feet in the air. Not a cloud was to be seen, not a ripple in the water, but perfect visibility above the low layer of haze, so that much of the Cascade range and snow-covered Rainier and Glacier Peak were all included in the panorama which rimmed the horizon.

Usually I had one or two special things planned for the day-some flowers to examine, a nest to search for, or a newly arrived bird to check. But today was free, so I decided to make the grand tour of the bay, which included the circuit of the west side and the newly excavated canal which ran close to the much-traveled highway. Then the passage along the residence district on the north side where gardeners whistled as they manicured the fine lawns and gardens, past the tiny lighthouse, and over the open water which marked the joining of the bay and lake. Next I would scan the log rafts which floated at anchor for a quarter of a mile on the south side, after which I would direct my canoe through the channels in the Arboretum, and back to the canoehouse-a quiet and peaceful trip of about five miles. I did not anticipate seeing much wildlife on so bright and still a day. But there were more fishermen than usual. Why not forget the birds and mammals and see what the anglers were catching and how they were doing it?

Not that it was much of an area for fishing. But plenty of people visited it, nevertheless. Few were lucky. They were the ones who had a feeling for, and a knowledge of, fishing. But, whether lucky or unlucky, many came often, perhaps with the hope that the next trip would see a turn for the better. The attraction of certain locations for fishermen has always impressed me. That day it recalled the men whom De Maupassant described in his story, "A Fishing Excursion." The two Frenchmen had often fished together before the Franco-Prussian war and, when they accidentally met during 
the struggle, the memories of the many trips to the favorite fishing spot made them decide to return even though the advancing Germans were close to the stream. They reached the place, fished with great success, but were picked up by an advance guard and taken to headquarters. The German officer who questioned them was not convinced that the men had come for fishing, and he ordered them to be executed as spies. They were shot.almost immediately, after which the fish were turned over to the German cook to be prepared for the evening meal. Perhaps some enthusiasts would say that it was not too exorbitant a price for a perfect day of fishing.

The first part of the day's trip took me along the canal just back of the stadium, a place much frequented by boys because it was easily reached by bicycle or foot. I paddled easily, looking at the knee-high stumps of the trees which had been removed by beavers, watching the water run down my paddles to form little rings as the drops struck the placid water, listening to the song of the russet-backed thrush in the deep undergrowth. The fresh scent of the cottonwoods was as unmistakable as the odor of lavender when a bureau drawer is opened. Then I saw a bareheaded boy of about ten coming slowly down the slope from the golf course, picking his way so that his legs would not be scratched by blackberry vines. He crossed the road, looked around as he stood on the canal bank, and uttered a cry that made me force my canoe to the place where he was standing.

"What's up?" I called. "Hurt yourself?"

"The pole," he cried. "My father's fishpole."

"What about it?"

"It's gone. My dad's pole. I stuck it on a stick on the bank and went up to watch them play golf. It cost twelve dollars and forty cents and now it's gone, all of it." The tears flowed freely.

"Perhaps a fish pulled it into the water." 
"Somebody took it 'cause the wooden case is gone too. Gosh, oh gosh." He had slumped to a stricken man of sixty. "Maybe, if you wait around, somebody will bring it back."

"No use at all," he sobbed. "Anybody who would take a twelve dollar and forty cent pole would never come back. What will my dad say? He didn't want me to take it in the first place." I watched his bent figure until it disappeared behind the athletic pavilion.

But it was not all to be tragedy. I encountered another fishing party near the crew house. A young mother in a blue "clam-digger" outfit had brought her two children, a brown hatless boy about six and a plump little brunette of four, on an adventure into the wild. A lunch basket stood nearby. All three sat on an old bulkhead, legs hanging over the edge, neatly peeled willow poles in hand, and eager eyes intent upon the bobbing corks. The little girl called to me:

"We're fishing," she said, "and we're catching fish." She pointed to water-filled jars with bullheads swimming in them.

"We have seven," said the mother. "I caught one, but each of the children has three." The children looked happy and important as she said it.

"Are you going to take them home?" I asked.

"Oh, no. We've decided to let the fish see how it is up here on the shore and then we'll put them back."

The canoe was soon out of the canal and in open water along the margin of the islands which had been formed when the inside channel had been dredged. Two men were casting bits of red cloth toward the edge of the cattails. I pulled a little closer.

"Do you mind my watching?" I asked.

A bass voice came from an enormous man in a red shirt:

"It's O.K. There's no law to stop you even if we wanted to -and we don't."

The other man, Nordic in appearance and imposing in a new blue-checked jumper said: 
"This kind of fishing shows that it don't pay to lose your temper."

"What do you mean?"

"These bullfrogs want to run the whole show. They jump at everything around their bailiwick. We like them to feel that way about the red flannel on our hooks."

There was a movement in the water, a splash toward one of the red lures, a struggle, and then redshirt pulled out an enormous frog whose yellow throat proved it to be a male.

Bluechecks smiled.

"I like to catch things whose meanness is the cause of being caught. And it's fine to eat their legs afterwards. Nothing's better."

The men told me that they fished every late spring for frogs and then fished for bass in summer. Frog fishing was easy if you knew how but not many people went after them. They thought they liked it because it took them back to the time when they were boys and had fished for bullfrogs in Indiana. I waited until they had pulled in another struggling victim and then moved along.

The next stretch of the grand tour was shallow, and from a fishing standpoint, unproductive. But the trip was not unpleasant. I watched the tule wrens carrying food to their nests, heard the singing of the blackbirds, and saw them mob a heron which had been careless enough to fly over their nesting territory. They hovered oyer the bird and struck at it viciously. I could look down in the water and see the aquatic growth, just beginning now, but which later would block the area in places. Then I passed the curried and polished part of the bay, with large houses in the background, lawns running down to the water, and piers and power boats. There was little here to remind me of the marsh other than the mallards which had been fed so regularly that they depended almost entirely on handouts. The shrubbery was full of singing warblers, flycatchers, and fat robins, and 
out near the very point I saw a flicker which was drumming loudly on a dying tree.

I crossed the bay to the east end of the log boom where many surplus logs were held until required by the mills. Tied to the peak of the boom lay a trim motorboat about twenty feet long, decked in the bow to make it seaworthy on the Sound or in the much rougher water of the Strait of Juan de Fuca. A fish pole projected from the stern. The occupant, a strong-featured and powerful young fellow, occupied himself in changing some tackle. I had no intention of stopping but he waved and I accepted his invitation to come over. A brown spaniel dog in the cockpit wagged its tail in friendly fashion.

"Catching anything?" the man asked.

"I'm just sight-seeing, and have no tackle with me." I looked at the lure he was attaching-a five-inch strip of some sort of composition material, shaped so that it would skitter in the water, and highly colored. It glittered in the light. "What do you call that? I thought I was up on most baits but that's a new one to me."

"I can understand that," he said. "Because I made it myself. You probably know most of these." He opened his tackle box and showed me a tray of assorted gadgets, many of which I never knew existed. Short ones and long ones, of every color and shape, and of queer designs.

"These are all bass lures," he said. "Some of them are good but I never found one that was the killer that this one of mine is. You're a fisherman and know what I mean. The bait you use is a whole lot a matter of sentiment, and when you make one to your own liking you think it's better than anything else. Probably nobody else would use it at all."

He was the first westerner I had met who preferred bass to salmon fishing. I asked him why.

"Too much gear in salmon fishing. You have enough on your line to drown a fish. Bass fishing is a battle of man and 
fish without handicapping the fish when it is hooked. A light rod, a clean cast, and a big bass on the line strikes me as topping any other kind of sport."

I pointed to a thermometer in his tackle box. "Do you carry that for any special purpose?"

"Yes, sir. It's no good at this time of year but it's my fishing guide in cold weather. I've found out that you can't catch smallmouth bass around here if the water temperature is below forty-five degrees. If it gets below forty the bigmouths quit, too. I figure they get kind of dormant in the colder water and so I save myself lots of fooling around."

"This is a swell boat." I said. "Local built?"

"I built it in my back yard."

"Your own design?"

"Only in a way. I took what I thought were the best points of two or three craft and combined them. This is the result."

He told me how carefully he had selected his material, how he had bought most of his fittings at surplus stores, and if he found them too expensive had made them himself. $\mathrm{He}$ had rebuilt a second-hand marine engine. The result of the economies was a boat at half the price he would have had to pay on the market.

"I got my money back in less than two seasons," he said, "from the savings in boat rentals and auto expenses, and on ferry trips I used to take when I went after salmon. Now I stay close to home, and by figuring the best kind of gear and knowing just where to find the fish I make out all right. I got this one just before I tied up to the boom." He showed me a big-mouthed bass that would weigh about three pounds.

The man interested me. The aptitudes he applied to his fishing should tell me something about the nature of his work. He was a strange combination, this man who had the ability to overhaul an old engine, to make his own fittings, and to design and build his boat. I had seen many good fishermen, among them the best of dry-fly casters, but I had 
never seen a scientific fisherman who used thermometers as a fishing guide, who tested every kind of lure and made some of his own, and who constantly studied the movements of the fish for which he fished. I had never before seen a fisherman who kept his boat in the perfect shape you would expect to find only on a navy craft. What was his profession? I thought I knew and was anxious to confirm my opinion.

As I said good-by and released my hold on his boat, I asked, "By the way, what is your business?"

The answer was as I expected. "I'm in the engineering department down at Boeing's."

I ate my lunch as a light breeze drifted the canoe past the big apartments at the south end of the entrance into the bay. Between bites of beef sandwiches and an apple I rounded the log boom and followed the water between the boom and the shore. The ducks and other waterfowl which were always plentiful in winter were now on their lreeding grounds and the place was almost deserted. A large heron stood motionless on the logs, a couple of crows hopped back and forth and examined the bark for worms and insects. A coot, or mud hen, moved hurriedly into the marsh growth. Most of its kind had left but it was one of the few that had remained to nest. It would not be many days before I would see the young near the cattails where the old birds would be feeding them with a fine weed which they had dived to obtain. The young would be reddish and nothing like the sober parents which were almost entirely black.

I did not see fishermen again until I had gone through Gadwall Cove and into the channels of the Arboretum. There, as I expected, I found a dozen or more Negroes sitting comfortably on the bank, all still-fishing with poles resting in the fork of a stick and with their floats high in the water. I thought that I could learn much from the serenity of these people for I had always been a fly fisherman and a troller because I could not enjoy inaction. Here there was no 
premium on activity; there was no continual hauling out of lines to examine and renew bait. There was no movement from one spot to another in an effort to find a better location. They had selected their niche for the day; they had come to relax and enjoy themselves. Their method was to let the fish come to where the bait had been placed. They did not propose to run around and hunt the fish. If the whole day passed without the bobber frantically indicating the presence of a bait-sampler, why worry? There was the pleasant bank to sit upon, the warmth of the sun to give them perfect comfort, other fishermen to joke with, a basket of lunch, a cigarette or pipe, and plenty of tobacco..If one caught a fish, all watched and enjoyed it. They kept their eyes on their floats and between times looked at the sky and the birds and the smoke from their tobacco. They watched me from the time I came from under the little bridge until I left. Their faces were impassive and they did not speak until I first spoke to them, and then their faces lighted up and they quipped about the day, my canoe, my binoculars, and the folly of pushing a paddle when a small investment in an outboard engine and a few cents worth of gasoline would enable me to rest and enjoy life.

Just before the bank flattened out and the area became marshy, I approached a couple I had never seen before. The man, quite tall but a little stooped, wore army khaki trousers and a dark sport shirt. An old panama hat completed his costume. The open shelves of his spreading-type tackle box contained an assortment of gadgets so varied that it completely eclipsed the collection owned by the man I had met out by the log boom. Spoons, flashers, hook extractors, flies, leaders, and the like filled every compartment. His pole was split bamboo, closely wrapped, and the line which ran through the agate guides was an expensive one. The float had evidently been hand painted for, like the banner of the 
ancient knight, it bore a strange device-I thought it was a corkscrew spiral with dots between.

The wife was cleanly but plainly dressed in a brown onepiece affair. She was a large, very dark woman whose face in repose expressed the strength and character that might come from a life which had not been too easy. But when I spoke to them and they answered, she smiled with an expression showing that, for her, life still held a lot of enjoyment. Her firm hands grasped a long willow pole from which hung a line and float which, unlike any others I had seen along the canal, was bobbing violently. She set the hook with a quick movement of the wrist and then drew a good-sized perch from the water. The man looked at his own bobber but said nothing.

"You got yourself a good one," I said.

"It's my lucky day," she replied. "I came down without aiming to fish. I cut a pole just to pass the time."

"You enjoy it?"

"It's just a pastime. My husband's the one who likes to fish. He's an expert."

My canoe was almost past when she smiled again and said:

"He got three so far, I got eight."

Fishermen seldom stopped in the marshy strip between this point and the bay. I was warm and thirsty and was glad to get out in the open where I could take advantage of the light but constantly strengthening breeze. Flatties and starboats had begun to appear; they were slowly making for the lake and the stronger winds which would come up a little later. A little puff of wind would send them along for a few yards and then the boats would drift until another puff came.

I thought that the day's fishing was over, but just before I reached the entrance to Canoehouse Bay I recognized two men who were casting plugs from a very short squarebuilt boat. They were young Japanese, from their clothing 
evidently ex-G.I.'s. I had seen them infrequently in the area. They nodded in friendly fashion when I came nearer and continued their casting, swinging their short rods with an easy motion which made the reel spin. evenly and sent the plug out the proper distance where it stopped and then dropped within a yard of the rushes or cattails.

I considered the fishing methods I had seen during the day: the huddled search for the legal limit near the canoehouse, the bullhead catch of the young mother and her children, the case of the irritated bullfrogs, the scientific analysis of the temperature and bass preferences, the relaxation, and the easy attitude of the little group near the Arboretum. How different they were from the systematic and chess-like approach I was now observing, a method which had almost been brought to a science on a formula like this: bass which are feeding near the rushes always attack a splashing and moving bait; to take bass it is only necessary to continually drop a properly handled plug in the right place; percentage will take care of the rest.

Whether they realized it or not, these men followed this formula. They worked with cool and tireless efficiency; they spoke infrequently. I am quite sure they were unconscious of the beauty of the day, the rising of the wind, the presence of any other fishermen, the sailboats which now heeled to the water as the wind carried them along. It was not that they were incapable of enjoying such things, but they could not work efficiently if they permitted such things to distract them. Fishing to them was a sport and one they thoroughly enjoyed, but they did it with seriousness. They certainly did it well. I did not see them stop to untangle a backlash or fail to place the plug exactly where they wanted it. Their precision recalled that of a friend of mine who used to put a pail of water on his lawn and then practice dropping a fly into it.

I felt free to ask them about their catch for they knew I 
did not fish. One of them held up a bass which would weigh at least two pounds and said:

"We have five as big or bigger than this."

He had picked up the fish as he made his cast. He laid it down before the plug was ready to be reeled in. There had been no waste movement, and there would be no break in their rhythm except when they caught and landed another fish or moved elsewhere.

I inquired about the fishing when I reached the canoehouse. The manager said:

"The old boy caught his limit and left. Somebody else moved right into the spot where he was anchored but I haven't seen the new man catch a fish. But the men seem to be having a good time."

When the canoe was put away and I was ready to go, the manager said:

"Here's some fish for you. They've been on ice since I got through cleaning them. They will be as fresh and sweet as when I caught them this morning."

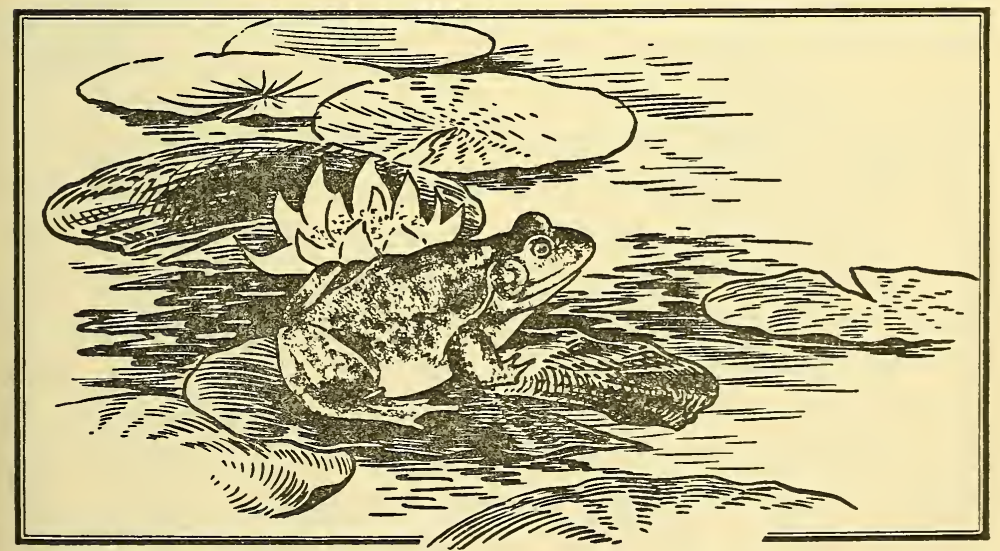




\section{The Bill of Fare}

\section{6.}

HOW IS THE FOOD PROBLEM MET IN the marsh? Is the question of supply one of chance or are there certain fundamentals governing it? I asked myself the question one morning in late May.

It was a week or two after I had made my grand tour of exploration and examination of sport fishing in the bay. The day was warm and decidedly not a time for action. The pencil and notebook lay in my lap but I made no entries, the binoculars hung from my neck and had been untouched since I entered the canoe. I paddled lazily with considerable intervals between strokes. I saw a redwing in the top of a nearby tree but none of those usually active birds flew past me. In the cattails one bird, a yellow-throat, the marsh warbler with yellow body and black mask, uttered a few notes, then was silent. There was no other singing. Half the usual number of swallows were in the sky. The urge to relax seemed almost unanimous all over the marsh. I think I could have dozed if something in the water had not attracted my notice. It was a peculiar dark spot, probably a little more than a yard in diameter, proceeding slowly, its margins changing shape slightly as it moved. Occasionally it came up 


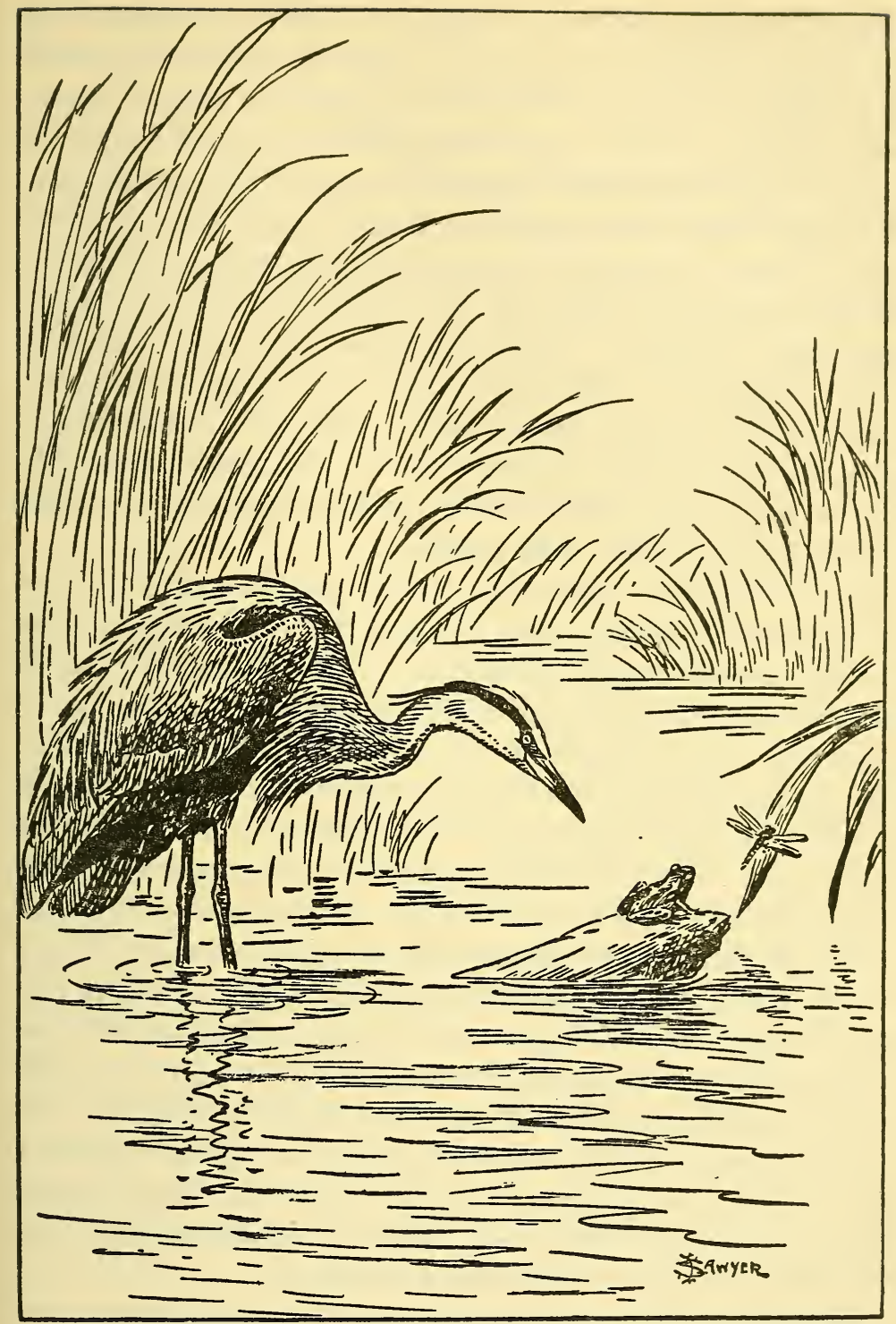


enough to ruffle the water surface and then it would drop down slightly and leave it smooth again. I soon found that it was composed of small fish held in a group by I do not know what. If there was a mature fish guarding them, I did not see it. They were closely packed in many layers so that the total must have been much in excess of a thousand. They moved slowly, fanning out at times, closing again, impressive in their numbers. Small fish of most species are not easily told apart except by experts but the identification of this school offered no difficulties. Each was a miniature of the mature fish: big head, smooth body, and dark in color. They lacked the transparency and pale color of many young fish and in the water showed as distinctly as India ink on white drawing paper. They were catfish.

They traveled close to the bank and through the submerged plant growth and beneath the overhanging and slowly swaying cattail leaves. In the open water they could have been instantly spotted by a kingfisher, merganser, or grebe, whereas in this shifting mixture of light and shadow they had a much better chance to pass unnoticed. When I got close to them they dived and scattered, but their dispersal was only momentary and they soon collected and swam quietly along again. This instantaneous dispersal served, I thought, to insure that no great paw of a bear would scoop them up by the hundreds, and to prevent any single blow from killing many of them. A fish would have much work in collecting any number of these frightened and scattered midgets. I let the canoe drift idly with them. Occasionally one would come to the surface as if for air, but I saw nothing to indicate that they were feeding. Indeed, many people who were not informed would wonder how these tiny things could find food at all.

I have learned that, although it does not require extensive knowledge to make superficial observations, there are certain elementary scientific facts which must be understood before 
the method of operation of such a natural unit can be understood. Most important is that each community like a marsh, prairie, woodland, and desert is a tight association of many related factors which tend to make the area a selfsupporting natural unit. The residents are interdependent and lead a life made possible only by the continued existence of other members of the community.

As applied to the marsh, this means that fish, fowl, plants, and other forms of life are associated because each of them makes some contribution and receives some benefit which enables them to survive as a group. Except for the radiant energy of the sun, which is the basis of existence for all living things, the group is almost self-sufficient.

I thought of this in terms of the catfish flotilla which navigated within a couple of yards of my canoe. It is a part of the marsh community and it is safe to assert that thousands of other such assemblages have traveled these same canals and that a certain proportion of the individuals have matured and then produced other schools. Such defenseless and tender forms of life certainly cannot forage here and there for food. There must be a regular and certain supply always ready for them. In fact, there must be some assurance that every form of life in this community can find food sufficient for its needs. All items in the complex bill of fare must be constantly forthcoming if the residents are to endure. Each has its own food requirements; each will die if deprived of these requirements; each must depend upon the continued and successful satisfaction of the group needs. Because there is scanty discussion of this phase of community life many people know surprisingly little about it.

Once I took a high school lad, a friend's son, through the marsh. The day was hot but he insisted on doing his share of the paddling on the rather long route which we took. In some places the bay was free, in others the aquatic plants were thick enough to make paddling extremely tiresome. He 
sat in the bow and like all beginners dipped his blade so deep that each stroke brought up a heavy and messy strand of weeds. Finally he said:

"I don't like this stuff. It's a nuisance, it wraps around my paddle and triples the work. It ruins a place for swimming. There ought to be a way of getting rid of it."

I made no comment, but he did not let the matter drop:

"What's the trouble?" he asked. "You don't say anything. Am I wrong?"

"You're partly right," I answered. "From a standpoint of swimming and paddling, it is a nuisance. But from there on, you're wrong. You might as well say that you like lawns better than vegetables and grainfields, and you think that lawns should be put in to replace them."

"I don't quite get the idea," he said.

I explained to him that streams, lakes, and other bodies of water are heavy producers of animal and vegetable life, and that much of this life is of considerable value to man. A sandy beach makes a splendid place for swimming and sunbathing but is almost a complete loss as a producer of the things that man and other animals need for sustenance and shelter. Its shifting often prevents growth; moreover, it frequently lacks the essentials that produce growth. Generally speaking, it is as useless as the rock exposures and alkaline strips found in certain western agricultural districts.

The opinion of this boy is that of many people. They desire a summer place on a lake where the beaches are clean and sandy. They also want good fishing. If every property owner had this first wish granted, it would mean a deep and clean basin with no vegetation to clog or discolor the water. Such a lake might be a great satisfaction to bathers and a delight to the eye but where would the fish come from? We could not raise cattle if hayfields and pastures were converted into lawns. Cattle and fish must eat: cattle must have hay and pasture and fish must get their living, directly or 
indirectly, from the underwater vegetation. Without aquatic pastures there can be few fish.

The young catfish which moved along with no apparent desire for food had a vital interest in the plants of the marsh. They could seek the shelter of their leaves and branches as a refuge from the enemies that sought them. The plants were the source of their food. These tiny fish would eat either the microscopical plants or equally small animals, such as tiny hard-shelled animals called crustaceans. They would find millions of diatoms, those minute plants which float free or attach themselves to various objects in every body of water. This feeding would be a part of that complex affair known as the marsh food web. Almost every living thing would be represented in food chains either as a feeder upon other members of the chain, or as food for those members, or in both capacities. There are many such food chains in the marsh. Except under extraordinary conditions, there would be no danger of these young catfish lacking food. It was available in suitable form, animal and vegetable, and in such quantities that the young fry would find it everywhere. Failure to survive probably would be chargeable to causes not connected with the bill of fare.

The vegetation which the canoe passed appeared adapted to do its part in the marsh food web. Mustards and grasses occupied many of the high spots, and trees and shrubs had moved in where the moisture was not more than they could stand. Emersed plants, those partly in and partly out of water, grew in the wetter places, and floating types, some small, some larger, drifted around in the water. There were the acres of pondweeds which rooted in the shallower portions of the bay and lived there, submerged except for the blooms or tips of the leaves.

I continually observed the contribution which these various plants made to the marsh bill of fare and to the other needs of the local living things. The loosestrife furnished 
honey to the bees and home sites for the tule wrens, which, together with the song sparrows, carried to their nests billfuls of insects which they had taken from the stems and leaves. The cattails and the loosestrife provided all the nestbuilding material for the wrens, strips of leaves being used for the exterior and framework, and the cattail down for lining. The blackbirds nested among the denser growths of the plant and fed on the many insects which clung to the stalks and others which tunneled into the leaves. In the fall the birds, released from their nesting duties, flocked together and hunted insects all over the district. The marsh appeared to me like a complex factory in which each creature did small specific tasks, apparently unrelated, but all a part of a great unified operation.

I could not fail to notice how considerable a part the submerged, or underwater plants, played in supplying the items on the food list. When I saw them in the water they appeared much like the land plants but, as might be expected, their structure is quite different. The land plants, except for their roots, exist in a medium much lighter. than water, and much less able to provide mechanical support. Consequently land plants must be strongly built in order to withstand the rains, the strains caused by winds, and the results of frost. On the contrary, 'water is a much heavier medium than air, its movement in shallow places is not violent, and the support it gives to the plant is important. The plant structure thus has fewer strains to endure and smaller loads to handle, so that the underwater parts can be weaker and less resistant than like parts of land vegetation. I have often watched a plant when the waves from a passing boat agitated it. As each part yielded to the swells the whole became a misty graceful shape which changed to precise erectness as the waves subsided. All of its delightful freedom and underwater softness is lost if such a plant is brought into the air. 
Because of its extent, the variety of small animals, and the many kinds of living places it provides for them, the area about the underwater plants probably harbors the greatest concentrations of animal life in the marsh. Different small species occupy the diverse water depths. I found some swimming on or near the surface, some attached to, or creeping on, the stems, and with a small net I could scoop up many which crawled in the sand or mud, or buried themselves in the ooze of the bottom. I occasionally spaded up and examined material from the shallows. When the surface was still, I could look down in the water on the shady side of the boat and watch the living things moving about-small fish, crustaceans, and the like. I often saw mussels on the bottom and shells which had been emptied by the muskrats, and now and then a turtle would scramble off a log. I knew that the water abounded with animals of miscroscopic size, such as protozoans and crustaceans, which ate the diatoms. Many other creatures helped to make up the invisible population always present in water. A friend, an expert on limnology, or fresh-water life, allowed me to look through his microscope at many of the diatoms. They were enclosed in silica cases of a design daintier and a beauty more exquisite than the vanity cases of wealthy women. Seeing them I could understand why men have spent entire lifetimes in the microscopical study of marsh and lake life, a study so complex and involved that its details are quite beyond the reach of anybody but the specialists.

My trips through the marsh taught me something about the regularity of its wildlife. I became acquainted with the various nesting spots of the bitterns and knew that these locations were occupied each year by the same or other bitterns. I knew that the Virginia rails preferred certain dense cattail localities. The cliff swallows returned each year to nest in the only local substitute for cliffs-the walls of some of the University buildings. The green heron worked up and down 
the channel which had the most trees along its margin. The dragonflies hunted for insects back and forth over similar territory. Each live thing followed a certain pattern, occupied a certain territory, and preferred a certain diet. I could assume, as many ecologists had pointed out in other localities, that this marsh was quite well stabilized in its plant and animal population, and that the life within its confines was little changed from year to year.

Of course there were some shifts. I thought the marsh especially susceptible to modification through the action of man. The delicate mechanism of such a community could be affected by apparently remote things. I recalled the statement of a game management expert who said that man's introduction of the European carp had seriously affected the supply of duck food. He said no arrowhead could be raised in an area if numbers of carp made a practice of rooting about in it. I noticed the gradual recession of the dense cattail stand in the place where the water from the boiler of the University power plant is discharged. Something proved injurious enough to make the plants retreat until now an area of perhaps two acres is bare. If man filled a place by dumping soil, water-loving plants immediately disappeared and soon willows and cottonwoods began to sprout. If his dredges made a new channel, then the change of plants was almost complete.

There were other changes not due to man. When the tiny duckweed found the season entirely to its liking, it floated about in sheets so dense that a wind would blow it up on a low spot in windrows. The shutting off of light by such floating blankets seriously retarded the bottom growth and thus indirectly affected the frogs, minnows, and other aquatic animals which depended on the plants for sustenance and shelter. I did not find it difficult to watch the struggle year after year as each plant maintained itself successfully in the areas for which it was best fitted, continually reached out to 
extend its boundaries, met the attack of invading and competing species, and frequently was forced to retire as conditions of soil, climate, and water depth changed. Loosestrife could not remain in deeper water where cattails flourished successfully, and when the depths increased still more the cattails had to give way to submerged plants.

I thought of these larger plants as I watched the shifting which took place. The same alterations occurred in the animal life as well but were much more difficult to see. The cattails and the loosestrife were constantly before my eyes and could be watched, but it was not possible to follow the fortunes of the young catfish and determine accurately their fate. Although I passed through the canal two or three times a week, I never saw them again. But I knew that all such creatures were being constantly harassed. On every trip to the area I saw small fish leave the water in a tiny arc as they endeavored to avoid a larger fish when it made a dash at them. The pied-billed grebes dived continually close to the margins where minnows might seek refuge. Some species of ducks took such food if they could capture it. The herons and the bittern were adept at fishing. I wondered what percentage of the young catfish became a part of the marsh bill of fare, how many succumbed to such factors as pollution and disease, and what percentage grew into mature fish? And I knew that in this community the problems of all living things, large and small, were similar to those of these catfish. Sudden alterations due to floods, low temperatures, or storms might be a serious threat to the whole marsh. Each radical shift caused destruction, sometimes unseen for a time, which could be withstood only because of the extreme fertility of the survivors. Each considerable change would bring about readjustments with perhaps the disappearance of some forms and an invasion by others. But in spite of these variations the integrity of the community would be maintained, and it 
would persist until alterations were drastic enough to affect completely the characteristics of the area.

I should like to have followed the fortunes of these catfish and to have observed their part in this remarkable food chain where tiny animals feed upon tiny plants, larger ones on smaller ones, thus building up creatures such as frogs and small fish each of which can take, as it pleases, its choice of food from a lengthy list of smaller and weaker members of the community. But they, in turn, become a part of the bill of fare. These frogs and our catfish, dominant over many forms, are dominated by others in the ascending scale. Bass raid the tangles where the smaller forms hide, but the bass are not safe from the fast-swimming otters and minks.

When I consider the apparent ruthlessness of this living bill of fare, the changing position of the participants in the program appears as a balancing factor. The tiny catfish from the very start were at once predators and prey. They were at the mercy of many living things, even of dragonflies and predacious insects of other species, but they, in turn, could prey upon microscopic animals. Without exception, and regardless of the final size of the creature, its young is subject to attack, often by animals which, when the young attain maturity, would be preyed upon by them. Predation is not necessarily by larger creatures: ants and lice are quite capable of killing a whole brood of nestlings, even of the fiercest of hawks. An injured bird, which would survive if left alone, loses its standing in the predator list, and usually becomes the prey of some enemy conscious of its weakness.

Although this is hardly a scientific observation, I cannot help thinking that, as a lunchroom, the marsh is operated on a unique but extraordinary plan. The living patrons exist indirectly and sometimes directly on vegetation, and on each other. The species seem to follow the principle, "It is all right for you to eat some of us if we can eat some of you." It is amazingly simple. If the population of any species gets too 
high, it is adjusted by feeding the surplus to the other marsh dwellers, or to visitors. This method effectively relieves the pressure by eliminating the extra population and at the same time furnishes additional provender for the individuals which remain. Think of the economy of a plan which, when the food supply gets short, solves the problem by cutting down the number of guests, and then serving those which have been eliminated as the main course. 


\section{Shells on Union Bay}

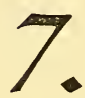

THROUGH WATCHING AREAS LIKE THE Union Bay marsh where wildlife is subject to constant contact with the city, I have learned that the direct action of man through such agencies as shotguns, traps, slingshots, and domestic cats and dogs is not the only disturbing factor. Other influences, indirect and often quite obscure, may have far-reaching consequences. The fills, the dredging, the erection of buildings may, or may not, be of importance, but I like to watch all changes, however slight, and weigh their effect. This is the story of a shift of apparently no moment but which has greatly altered certain conditions.

One morning in late spring I heard the crew turnout as it prepared to take to the water. The new and imposing shellhouse, only a few rods away from my canoe, was completely hidden from view by the six-foot cattails, but I knew what was going on as well as if I were sitting on a corner of the concrete ramp which lay between the shell storage room and the water of the inlet. The engine of the coach's launch snorted and popped and then subsided into smooth action when it warmed up. I could hear the voices of the crew men as they prepared to remove the shells from their racks and 


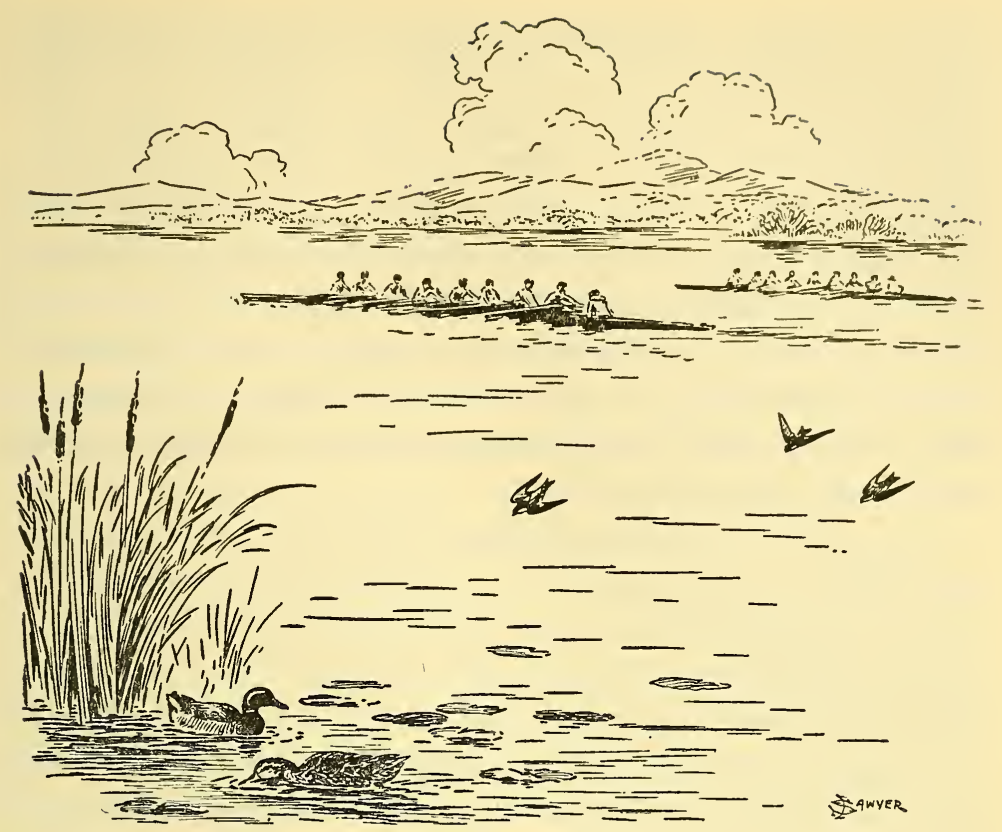

to carry them to one of the landing floats which lay at right angles to the ramp. Then, when the command was given, the men would lower the shells and place the delicate boats on the water as deftly as if they were handling a toy sailboat instead of a sixty-foot craft capable of seating eight oarsmen and a coxswain. There they would wait with the blades of their twelve-foot oars held vertically until, upon a command from the coxswain, they placed their sweeps in position and stepped carefully and smoothly into the fragile, narrow shell.

The day suited equally the oarsman, the vacationist, and the local wildlife. The thin haze made everybody want to push beyond it, the slight chill in the air invited rather than repelled action. The movement of the birds indicated contentment. The tule wrens carried food to their young, the song sparrows sang as they looked for insects that might be on the cattails, and the mallard hens up-ended along the 
marsh margins. I had been grounded on a small flat for fully ten minutes before I noticed a bittern standing a few yards to my right, with body stiff and head pointed upward. A Traill flycatcher, sitting almost erect in the manner of its kind, called from a low willow and from time to time flew out to snap up a passing insect. Odors filled the air. Predominant was the keen pungency of the marsh itself, but mixed with it was the unmistakable sweetness of the cottonwoods, the smell produced by the sun on the dew-covered vegetation, and the acrid but infrequent scent of rubber burning on the nearby sanitary fill.

The prow of the first shell appeared and almost immediately all three craft and the coaching launch passed me. The black outriggers for the oars projected like the legs of a huge insect. A little wave curled and bubbled at the bow of each boat. Eight stalwarts responded to the cadence set by one small coxswain. The passing of a shell at a distance is smooth, powerful, and graceful, but often the feeling of speed is lost in the vastness of the background. But here in the marsh and so close to me, all other impressions were subordinated to that of swiftness. What would aborigines, viewing these contraptions at some distance, have thought of them? Not as some kind of a bird-birds seldom confine themselves to one plane and almost never swim continuously at high speeds. Not as mammals, for mammals do not make an even display of the upper part of their bodies as they swim. They might have thought of them in terms of water striders, those longlegged insects which do not swim in the water but use their legs to propel their slender bodies swiftly, but more or less irregularly, over the surface film. That is somewhat the nature of the shells: they seem to move on, rather than in, the water as does an ordinary boat. Shells are designed for lightness, shallow draft, and streamlined curves so they can be operated with great speed. But, like the water striders, 
the power is not applied quite continuously so that there is always a small but noticeable unevenness in the movement. The birds at the mouth of the inlet appeared accustomed to the passage. The coots pattered a few feet and then settled down again with the clumsy lunge which always sent up a shower of drops. The mallards quacked and flew but without concern and soon dropped into the water and began to feed. The song sparrows did not cease singing. The bittern, perhaps startled by the sound of the engine, stopped posing and moved slowly into the cattails. Swallows attracted by the motion of the shells swooped close to them for a few rods. Nowhere was there any evidence of alarm.

The three shells and the launch came to rest about half a mile away. The voice of the coach could be heard but his words were not intelligible. The men had stripped off their shirts and through my binoculars I could see the rhythmical play of their muscles as they practiced starts. The gulls on the log rafts rose in a flock, then circled and returned to their resting places. The practice continued. Each trial start approached closer to the lake until the shells left the bay and disappeared to the north. For the moment I could see no other craft. If there were any fishermen they were in the channels. The area was as quiet as a mountain lake, and apparently free from all city pressure. The fact that the crew had merely made a passage through the marsh and would be away for most of their practice heightened my previous opinion that its impact upon the wildlife was very light. I was correct in assuming that the activity around the shellhouse would have little effect on any but the wariest of visiting species. But were there any other hidden factors that might be of enough importance in an inquiry which concerned the relations of man and wildlife? It would be well to look for them.

While I poked about the various quarters of the bay, I considered its early history and that of rowing at the Uni- 
versity. The building of the ship canal between Puget Sound and Lake Washington had lowered the lake seven and onehalf feet below its previous average elevation. Before the work Union Bay was a weed-free and rather deep sheet of water. When the heavy timber around the bay was being logged, a mill had been located on the north bank and steamers called at the dock. The first shellhouse was situated on what is now the west side of the marsh. The lowering of the lake left shallow water and mud flats which necessitated moving to Portage Bay, a part of lake Union just west of Union Bay. The next to last shellhouse was built on the northeast side of the ship canal where it entered Union Bay. It has only recently been replaced by the concrete building inside the marsh area. The type and cost of the structure indicates that the site is permanent.

I was convinced that the earlier days of the sport had little effect on the marsh wildlife, either when the shellhouse was kept in the present marsh area or when the crew operated from the canal. There could have been no direct evils caused by proximity: the practice routes did not cut across the marsh, and the birds did not frequent the deep water of the canal because food could not be obtained there. But had the construction of the new quarters altered the situation? I wondered why I had not given the matter any previous thought.

I paddled to the mouth of one of the channels leading into the inlet and looked about. The new shellhouse was on the margin of the marsh to the east of the baseball field. The wreck of the old canoehouse stood just to the south. The manager and his canoes had transferred residence to the former shellhouse on the canal. The move had probably made little difference in marsh relations. I supposed that as many people formerly came to the canoehouse as now came to the new rowing headquarters. And yet I knew that many changes had taken place. They must be attributed to causes other 
than the mere substitution of one collegiate activity for another.

As I entered the inlet I found myself listening for the typical song of the area, that of the Traill flycatcher. Formerly its soft lisping note could be heard all through the nesting season. I wondered why I did not hear it until I realized that it had come always from underbrush below the cottonwoods or from the willows, and that all of this growth had now been removed. Then the reasons for absence of song became clear; they were due not to the existence of the building, but to the changes in the landscape made necessary by the new activity.

The absence of wood ducks seemed to confirm this explanation. I had not seen them in the vicinity since the new structure had been started. Before that, they had become a little more numerous each year and had begun to nest in the area. The manager had cultivated the mature birds. He had attracted them by regular feeding and had so far won their confidence that, when the first brood ever recorded in the marsh had been hatched, the parent birds had brought them to the float to feed. I had often watched these tiny and timid bunches of gray and brownish-black down as they rushed for the bread which the manager tossed on the water. Because nesting sites largely control the population of these lovely green- and violet-crested birds, we constructed some wooden nesting boxes as a substitute for the holes in trees which they prefer, and had put them in the large poplars to the north of the canoehouse. Our prospects of establishing this most striking of all American ducks were abruptly ended when the preparation of the building site necessitated the cutting of the trees and the filling of the marshy shore. The wood ducks have permanently disappeared from that section of the marsh, and so far as I know there are no proper sites near, although there may be some just outside the marsh.

I studied the area further. The inlet had been a shallow 
place, much like the swampy spots where, as a boy, I followed the shores and caught frogs so small that it required all the persuasion of which I was capable to induce my mother to cook the legs. The area housed tadpoles, crayfish, minnows, and large quantities of underwater plants. Many birds, including practically every strange migrant, sooner or later found their way to this rich food. If it had been a motel a No VACANCY sign would have been constantly on display. Willows and cottonwoods brought in warblers and flycatchers. Small mud flats at the northern end offered inducements to shorebirds. The manager's habit of feeding the ducks and his protective attitude toward them held many birds in the area. Some mallard hens never failed to bring their young for a morning and evening. snack. The total area of the inlet was about equal to two or three city blocks, but it played an important part in the total marsh economy.

The changes which I saw were not extensive from the standpoint of acreage. The bottom had been dredged deeper, the trees removed. A small peninsula in front of the canoehouse had been eliminated, the two points of the inlet had been rounded. The channels had been widened to permit the passage of the shells. A small structure had been erected to house the coaching launch. The area had formerly seemed rather crowded and untidy; now it was quite open and many would have thought it more pleasing to the eye.

I heard the crews returning after the practice. There were the cries of the coxswains as they encouraged the oarsmen or counted the stroke, there was the regular movement of the sweeps as they plunged into the water, made their stroke, and then returned to start another cycle. I clearly caught the sound of the coach's launch, his megaphoned remarks as he criticized the form of the individuals or of the crew as a unit. The men lay back as they finished the stroke, then moved forward with feathered oars until ready for the catch. The eight blades swung into rowing position 
and dipped simultaneously in preparation for the mighty sweep which sent the boat hissing through the water. The birds moved out of their passage as before-warily enough but without alarm or extreme haste.

The shells entered the inlet, backed-water to a stop. The crews got out, parked their oars, and then carried the shells into the storage room, a place full of enough racks to accommodate three or four dozen craft. The bodies of the men were wet with perspiration, their breath just a trifle short, but there was little sign of fatigue as they headed for the showers. The coach launch pulled up to its landing and the field work was done for the day. In a few minutes the place was deserted.

As the building grew quiet and I resumed my paddling I thought how easy it was to see the effect of environment on wildlife and how much more difficult it was to see its influence on man. The crews of the Pacific slope were almost always near the very top of the rowing list. Often first place at Poughkeepsie or Marietta was a race between California and Washington. How great a part did environment play in this result? Was the mildness of the climate of considerable importance in the production of a superior crew? There were many advantages in the location of the University. Here the crews could always find a sheltered place to practice if desired, or a stormy stretch to condition the men to rowing in a choppy or wind-disturbed lake. Possibly it went further back; the Northwest mountains, wheat fields, and forests might provide the proper places to grow men capable of developing the necessary skill to handle the heavy sweeps and the enduring stamina required to withstand the sustained ordeal of the races. Environment greatly affected other animals; what did it do to oarsmen? Someday a genius with a passion for such research may tackle the problem, and, fortified with data on genealogies, avocations, vocations, nationalities, diet, and heredity, may succeed in drawing conclu-

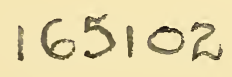


sions which will tell us much about the marsh and the crewmen who train so valiantly in its vicinity.

I moved along with the feeling that the crews were in no way responsible for the conditions which I was now convinced were greatly altered. But the change in location of the crewhouse, apparently. without significance either for good or bad, was proving to be the most disturbing factor in years. I passed the place where the canoehouse manager had first seen whistling swans in this city area. I had watched them pull food from a bottom just within reach of their long necks. I had seen them in the same place in several succeeding years but I knew that I would not see them there again. The water was now several feet deep and the vegetation had been removed by the dredge. I remembered the answer I had received from the greatest of wildlife management men, when I had written him as to the advisability and desirability of preserving areas like the marsh. He had replied that it was not easy to make an unbiased reply to my letter because the institution with which he was connected had just spent nearly a hundred thousand dollars to reproduce artificially the conditions which our district was so anxious to eliminate.

I did not think of this as a bit of propaganda nor did I think that the nesting site of a few wild fowl was of more importance than the erection of a third-of-a-million dollar building to house one of the finest of all collegiate sports. But since this story deals with the impact of man on wildlife it is essential to point out the unsuspected effects of man's handling of areas like the marsh.

I approached the point where a tule wren, the most industrious of all marsh architects, had built seven nests in the early stages of one nesting season. A tule wren had annually nested on this point. If it was ever used again for nesting purposes it would be by a pied-billed grebe or a coot, for the smooth water of the marsh now covered it. Two nesting sites 
of the bitterns had been removed. The yellow-throats and the flycatchers would have to move elsewhere. But it was not the removal of the nesting sites which was of the greatest importance.

Man's impact had been severe, if unpremeditated. The greatest harm was that primary requirements of food and shelter had been interfered with. Nobody had realized it; probably nobody would have acted differently if they had known it. The results would be far-reaching. There could be no interference with the principal elements of marsh economy without serious results. In many other parts of the area the result would have been negligible, but unfortunately this had been the key spot. Practically every rare bird that I had listed in the marsh had been observed in this bay. It was not unreasonable to think that from now on few new species of birds would be seen. They had been attracted by the food and the shelter. But the apparently insignificant changes had eliminated much of the cover. Dredging had destroyed the vegetation which sheltered the minnows, the crustaceans, and other animal life so much a part of birds' food and so much desired by them. At least temporarily, the value of the locality as the food center of the marsh was over. It had been an easily available wildlife restaurant but now the restaurant would be closed. It was as if a home garden had been torn up so that all of its fertility was removed. Were there not other spots in the marsh where the visitors would find suitable conditions? I could think of none which possessed so many advantages. But a philosophical attitude is much better than one of pessimism. If the area is destined to disappear as a marsh and become a brushed and combed addition to the district, the changes will have little effect on the general situation. If, on the other hand, enough of the public feels that there is a real need for, and value in, such self-supporting natural museums, no harm has been done which cannot 
be easily repaired. The dredging of a few small areas to the proper depth and a few years' time will produce crops of vegetation and animal life which will restore the conditions which have temporarily vanished. 


\section{The White Pigeon}

I FOUND THAT LIFE AROUND THIS marsh hotel certainly was not a continuous series of startling and exciting adventures. The days sometimes passed with a certain degree of smoothness, with no highlights and an almost monotonous regularity as far as conspicuous activity was concerned. But there were many smaller incidents and episodes which always go on where wild or human life congregates, and in which I found much to occupy my attention. I refer to the matters connected with the daily routine of the residents and visitors, to their family affairs, their squabbles, and experiences. Incidents of this sort form a remarkably revealing portrait of the marsh scene.

There was the episode of the white pigeon, which began to pay daily visits to the canoehouse. Where it came from is of no particular consequence, but I assume that it was one of a band of about two hundred which had become wild and nested on adjacent buildings and which kept fat from the pickings on the nearby sanitary fill. I watched it as it walked up and down the roof of a small shed.

"You're feeding it, aren't you?" I said to the manager. "How did you know?" 
"It's so tame and acts as if it had lived here all its life."

"Yes, and it certainly takes over the place," he said. "See how it acts when I put out a little feed."

He scattered a handful of cracked grain. The pigeon looked around to see that no other birds were present and then started to feed. But soon four blackbirds and a tame mallard hen joined the pigeon on the low roof.

"Now watch what comes next," the canoeman said.

The bird immediately stopped feeding, sidled over to the mallard, and without display of temper or nervousness, crowded her to the edge of, and off, the roof. It used the same tactics with the redwings until the roof was bare of birds and it was free to feed without competition.

"It will keep the roof clear until it has enough to eat and then it will let the others feed. I guess the redwings and the mallard realize that or they wouldn't get away so quickly. That fellow certainly knows how to get things done without stirring up trouble."

"Does it stay here most of the day?" I asked.

"It doesn't go far away. Sometimes it perches on the roof of the crewhouse, but it comes over here as soon as I get out feed or when a bird settles on the roof."

On my next trip I found two pigeons there-a brown female had joined the white male. The white bird paraded and cooed before her in a possessive sort of way.

"You started something," I observed.

"Don't you think it," he answered. "I'm not going to have a colony of pigeons messing around here. A public place is not for them. I told my wife we would have to get rid of them."

"How?"

"The next time we visit our daughter in Auburn I'll put the birds in a box and take them down there. They have plenty of room and the birds will like it."

When I saw him again, I asked: 


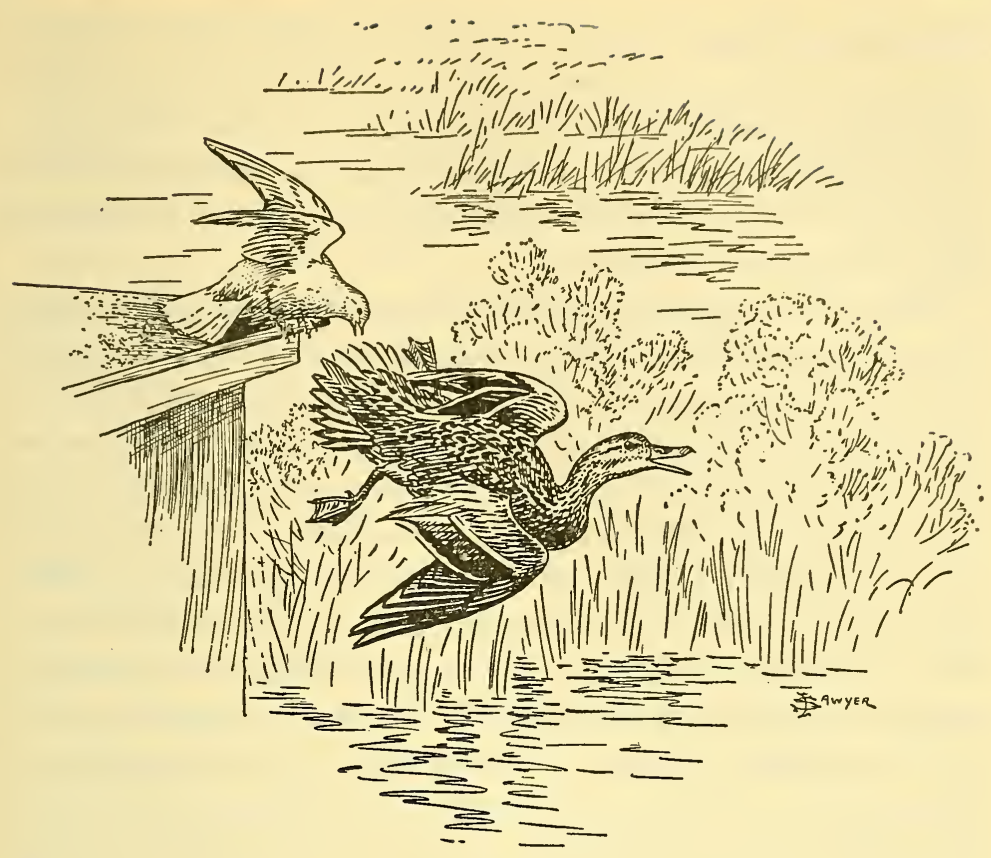

"How did the pigeon transfer work out?"

"Fine. I had no trouble in getting the birds into a box and they stood the trip O.K."

"It's all settled then?" I said.

"Not quite. The male stayed all right but the brown female was back again the day after I left them."

"What are you going to do now?"

He looked a bit sheepish and said:

"Nothing, I guess. My wife says that any bird smart and eager enough to fly thirty miles over unknown country to its old home thinks enough of that home to be entitled to stay there. And I guess she's right. You know it's hard to throw out an animal that adopts you."

That kind of tie-up can easily happen where civilization is close to birds and mammals. In the country it manifests 
itself when children nurse and raise a lamb which a herder disposes of because the ewe refuses to feed it, or when people mother a mallard hen and its young, or a boy brings up a colt or calf, or protects a wounded duck or goose which has wandered to the farm. It is so common that it is the rule rather than the exception.

Almost as common in such areas are accidents. They occur with regularity that might be compared with the automobile and street accidents of a city. In some of them I found the victims lifeless, crumpled, with no evidence to indicate the nature of their death. In others the cause was plain, as in the case of the robin which I found poised in an unnatural position on a hardhack bush. Its body was stiff, its wings partially open, and it did not move as the canoe approached. I wondered why until I pulled down the branch and found that a sharply broken twig had impaled the bird as neatly as if it had been spitted. Death had come suddenly for there was no derangement of wings or feathers to indicate that it had struggled. It almost floated there as a bird mounted on a hat might seem to float, graceful in outline and color, but ghastly in its omission of the one thing that originally made it so delightful-its pulsating. vigor and awareness of life.

Many are the traps for unwary things to step into. A black object swinging in the morning breeze attracted my attention. It moved slowly and without noise, in a long arc, and it twisted as it moved. It might have been a black yo-yo or a rubber ball attached to a string, except that it lacked the solidity of such objects, and swung as a last year's pine cone would have swayed in a light wind. It turned as I moved nearer so that I saw a red blotch on a black surface. Then I knew what it was: a redwing blackbird tangled in a thin piece of brown string. One end of the string had wound securely around the willow twig and the free end had in some way become wrapped about the legs of the bird so that its efforts to work free had more firmly netted it until at last 
it became a living pendulum. I hoped that the ordeal had not been long.

If there are many ways for the older birds to get into trouble, they are as nothing compared to the difficulties in which the young ones sometimes find themselves. Grim casualties come to mind but I prefer to relate an event which had a happier ending. One day I observed a dirty brown object the size of a golf ball which slowly moved on the marsh bank and wriggled and showed a convulsive kind of animation. I suppose that years of wildlife observance sharpens one's responsiveness to movement, for I saw it instantly even though it blended almost perfectly with its surroundings, and in spite of the fact that the canoe was moving quite rapidly. Completely nonplussed, I braked with the paddle and moved back to inspect it. I had to get within a yard before I realized that this animated ball of dirt was a young duckling. The thin layer of mud so covered it that I could not identify it until I took a small piece of branch and gently rubbed off patches. It lay in a hollow not much larger than my cupped hand. Almost exhausted, it struggled, stopped, resumed struggling, and squirmed like a turtle that had been turned on its back. What held it there? From the bow of the canoe I managed to reach and run my hands around it, which procedure showed that it was a young mallard firmly trapped beneath an imbedded stick of pencil size. The stick projected at an angle which, in combination with the curvature of the hollow, proved to be a trap which held the bird more firmly as it pressed forward to free itself. How long it had been struggling was doubtful, how much longer it would have continued as equally uncertain, but of this I am sure-it would have been doomed if I had not passed just as it was making another effort to release itself.

Such examples of marsh difficulty were quickly terminated; others dragged on for weeks. There was the case of the gull which temporarily became a shorebird. Six different kinds of 
gulls visit the marsh during the year. This one, the glaucouswinged, the largest, is distinguished from the others by the absence of black in its wing tips. I saw it first as a white patch moving in the tangle of cattails two or three feet back from the water, an unusual place for any kind of a white object and particularly for a gull. The day was cold, the wind pushed white clouds to the northeast, and two or three hundred gulls flew above the marsh. That was the kind of action they liked on cold and windy fall days. They cared nothing for moving about below as a chicken might move in a barnyard. I wondered why this bird had grounded and why it should behave in such an un-gull-like fashion. Gulls did not regularly practice methodical examination of the ground. They visited the sanitary fill and fought over scraps they found, or they pursued the other gulls when they had been fortunate enough to pick up a large or otherwise tempting morsel. The humdrum life was not for them. They ranged about constantly and, when tired, slept motionless on the athletic fields, the roof of the athletic pavilion, or on the exposed open flats which formed temporary islands when the water was low. Why was this bird behaving so unconventionally?

I determined to investigate and paddled my canoe close to where the gull stood inside the cattails. If, temporarily, it had become a shorebird in habits, it overlooked that fact when danger threatened, for it immediately. left the shelter of the cattails which many shorebirds would have sought, and entered the water, paddling just fast enough to maintain a position about a rod ahead of the canoe. As I increased my speed, the bird swam faster until it began to show signs of distress. I thought I knew its trouble and so I paddled until I was only a yard behind it. The single attempt it made to fly was a failure, for one wing refused to operate and the bird, realizing the fact, put no more strain on it. It neither made any further attempt to escape nor did it show any fear nor 
yield to any panic. And why should it? It had been raised on the islands of the Strait of Juan de Fuca or of Puget Sound where life had been a constant battle. It had been an adventurer from the time it could fly, had sought its food over a wide area, and had pursued it regardless of distances involved. It had no gentleness in its makeup. It recognized no right but force and, if gulls of this kind are known and esteemed as scavengers, it is probably because such food is easier to get and not because they will not take live food if the opportunity offers. It was a predator within the limits of its slow flight, physical strength, and build. It fought with its own kind, with other species of gulls, and with other kinds of birds. It squabbled and stole because that was the type of life which suited it.

As I approached, my dragging paddle came near the bird. It met it boldly with a forward motion of its head and a mighty attack which placed the full action of its bill on the thin cedar tip so that the marks on the paddle are still visible. Then, perhaps realizing that fast retreat was impossible, it remained by the side of the canoe as a cat might face a dog in a doorway. It opened its bill, looked at me, and showed no signs of yielding even though it was badly crippled. The water close to shore was so free from wind that I could see the reflections of the bird and the cattails. We watched each other for a moment. I wished the bird no harm; on the contrary, I wished it all the good luck it so badly needed, and so I left it. As I went around the little point where the canal opened into the bay I saw the bird still watching me, perhaps with some glimmer of an idea that the canoe and its occupant had been faced and vanquished.

For several trips after that I always saw the bird industriously covering the shore margins, working busily, picking up small pieces of this and that, determined to live, and putting out the effort to achieve that determination, afraid of nothing, yielding to nothing. I never saw another gull near it. 
I never heard any calls by it or by the gulls which passed. I have noticed that, although the glaucous-winged gulls do much flocking and nesting in colonies, they are not concerned with the welfare of their kind as the crows appear to be. In full possession of its strength, this bird would have been a member of the gull fraternity, but in its present condition it apparently had no standing and, if badly injured, it was barely possible that it might have been destroyed by fellow gulls as they have been known to destroy wounded birds of other kinds. But whatever the reason, it continued its lonesome course along the shore, and in only the small section which it considered sufficient to maintain it. I suspect there was little difficulty in finding food. There were seedsconcentrated pellets of nourishment-of the loosestrife and other plants, there were cattails whose stalks crawled with insects, and there was much succulent vegetation. The perpetual industry of the bird indicated that its food habits were flexible enough to accept the items which were plentiful.

One day, some weeks after, I saw the gull in the water but did not get near it. The following week end, I approached it slowly so as not to put it into unnecessary flight. It had progressed more rapidly than I thought-perhaps it had made trial flights on days when I had not been there, or possibly my presence gave it the incentive to rely again on the injured wing, for it rose easily and slowly. I last saw it on its way to join the gulls resting at the north end of the bay.

The dogs which visited the marsh might have made an interesting news story. They ran and romped and did not hesitate to barge through the muddy wet places so that their owners must have been quite unhappy when the dogs arrived home with their coats wet and matted. Their energy seemed like that of small boys, and, to many, their continual visits appeared pleasing and innocent. But the canoehouse manager had this idea about them: dogs, and particularly hunting dogs, should not be running through such places at any time, 
and especially in the nesting season. I agreed with him. I thought they added one more burden to the always harassed marsh life and did much damage. I am quite sure they did no killing but they covered all but the very wettest areas in the marsh, and, in addition to preventing many ground birds from nesting, probably broke up many nests that contained eggs. I suspected that their masters, many of whom prided themselves on their sportsmanship, had little idea of the extent of the damage done by their pets. These dogs may have been like those of the range areas which ran without the knowledge of their owners and attacked sheep. I wondered, too, how such freedom would react when they were taken into the field in open season. I fancied that the dogs which refused to stand properly, and which broke and ran down the field with birds scattering on every side, were such freerunning and poorly disciplined animals. One trio-two setters and an Airedale terrier-visited the marsh often, and when they began plunging through the cattails and bushes, their progress, aided by the keen noses of the setters and the industry of the Airedale, was effective enough to send a constant stream of ground birds into flight. The only places in which a duck could nest safely were those surrounded by water so deep that they must be approached by swimming.

An inspection of my notes constantly adds to the evidence that many of the small but interesting incidents which occurred in the marsh are directly due to the closeness of that important ecological factor, man. He built the ship canal and sent his vessels from over the world through it, he populated the adjacent shores with home owners and business people, college students and professors. This impact has made anything possible. It would not surprise me to see a Manx cat hunting in the grass, or to see a mute swan sail majestically along by the shore.

The other day a churning and splashing attracted my attention to the ship canal in time to see a miniature of a 
Mississippi River stern-wheeler chugging along as stolidly as if it were on its regular run. Where it came from or what it was used for, I have no idea. I have mentioned it only to illustrate my point that a man need be surprised at nothing. Parrots, once residents of the South Seas, and coypus, fur bearers from South America, are always a possibility-in fact both of them have been reported although I have not seen them personally. The live things which men keep in their homes, or on their farms, or in museums, for food, fur, or entertainment may escape. Where will they find a better refuge than in such a spot? The sight of a bird three feet high, with a blue bill, pink legs, and a white neck and black body, would not astonish me. I would realize that it was something that had escaped from the Woodland Park Zoo. An Indian canoe on the canoehouse float did not make me think that a native war was imminent. It had been shipped in for exhibition purposes and somebody had been curious enough to want to try it out. A feathered arrow half buried in the bank would not alarm me, for there was an archery butt a short distance away and I would know that somebody had overshot the mark in a trial flight.

It is not only the living things and mechanical devices propelled by man that have appeared, but inanimate contrivances as well. I never knew what might float into the area. A close inspection of some strange object bobbing among the rushes of the bay was always worth while. It might be a simple thing, but I found that I could always enjoy the simple if I took time to peer behind it and try to glimpse the complexity in the background. A crow flapped from a plank near a white object which floated on the water. At first I thought it a dead gull which the crow was checking as a food possibility, but I saw the crow's presence was purely accidental for the floating object was a doll, neatly constructed, with unbreakable head and eyes which closed. Its paint, still bright, indicated a short stay in the water. It had 
been windblown and had floated from a passing boat or from one of the houses on the lake. How did the child lose it? By its accidental dropping or by that inexplicable desire to throw something away which often comes to children? Perhaps it was only one of a dozen toys and would not be missed. Whatever the reason, here it was bobbing up and down on the rushes, its white dress greened by the contact, and looking very much out of place. I think that the little girl to whom I gave it still cherishes that water waif.

On another occasion, I discovered a model sailboat, fourteen inches in length, sloop-rigged, freshly painted, and in excellent condition. It had evidently come in on a good wind, for it was upright and might have continued indefinitely had it not run headlong into the shore where I found it moving up and down in the gentle wavelets. It bore no name or identification but the boy to whom I gave it now calls it the Dauntless.

Once I saw white objects on the water which I thought were terns, for no other white bird that visits the marsh rides so high. At a distance they floated as lightly as floating bubbles, which they proved to be. They were toy balloons which had been released at the football game the day before and had landed on the shore and water of the marsh. Where, but in this city marsh, would things which looked like white terns prove to be toy balloons?

The list of flotsam grew: rubber balls, large and small, several more dolls, two model airplanes in bad condition, canoe paddles, a life preserver jacket, a dinghy complete with oars, fishing plugs which I found firmly attached to willows, a lunch tightly and efficiently wrapped in oiled paper and in perfect shape, and inflated inner tubes. Also I found another class of articles, bottles, in numbers which several times exceeded the combined aggregate of all other objects.

Bottles came constantly under my observation, bottles of all types and for all purposes-beer, gin, Scotch, bourbon, 
and coke. Some still contained the corks and floated high. Others, uncorked, had shipped water so that often only the necks were above water. I saw them in almost every conceivable location: in small hidden inlets which could have been reached only by a series of varying winds, each of which pushed them to a turn where they remained until a wind from another quarter would carry them a little farther.

They rested on the flats where the shorebirds congregated, on logs where high water had left them stranded, and sometimes in the forked branches of some low hanging willow. I assumed they came from the boats which constantly moved through the canal, for there was almost no picnicking along the shores, and I had seen some bottles tossed from passing ships. Also I noticed that they were more plentiful after holidays when many boats had left their moorings, a time when the marsh shores were deserted because everybody was taking longer trips.

As I made my rounds and looked at the collection, I wondered if a report of their numbers and kinds would have any value for statistical purposes, and whether a weekly count would be any sort of index to total consumption in such fields. For so many boats, so many bottles of this, that, and the other. I marveled at the total absence of wine bottles. Were yachtsmen of so sturdy a breed that they scorned the less potent wine? Or was its absence explainable by some other factor? Would it pay the vintners to check closely this ominous situation? Perhaps this local sampling of taste might be accurate enough to use as a substitute for an expensive general survey.

It must be understood that my interest in bottles was not because I personally was concerned with such figures but because their presence in the marsh was often a source of great annoyance to me. I would find a subject which I particularly wanted to photograph in its natural surroundings. But how could the surroundings be considered natural when, 
within a foot of the bird, there stood one or more beer bottles with labels plainly showing? Had the publisher overlooked the presence of the containers and used my photographs, he would have unquestionably held me responsible for the complaints of the drys who might charge that the picture was published to show that even the birds enjoyed that particular brand. I would have been attacked by all the branches of the liquor interests: the hard liquor people because beer alone was advertised; the beer barons because a particular brew was mentioned to the exclusion of all other beers. That, I wanted to avoid. Consequently, though I made no attempt to police the marsh in general, I did make a practice when I found a bottle in certain spots favored by birds, of pressing the top of the bobbing container gently with my paddle tip, and holding the tip there until the cessation of gurgles and grunts indicated that the bottle was full of water and ready to join the others which must almost pave the bottom of the bay.

It may be that, some time in the remote future, workmen excavating in the filled land where the marsh once stood, will strike this stratum and make a collection that will be representative of the glass containers of this period. And if the savants enter into the discussion, as they undoubtedly will, there will be many a learned theory propounded to explain why and how these containers came to be distributed. with such regularity over so large a place. 


\section{The Track Near the Marsh}

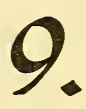

I SELDOM ALLOWED RAIN AND weather to hinder me if conditions in the marsh justified my canoe trips, but after I had paddled through two miles of canals without seeing anything of particular interest I decided to stop traveling and spend the rest of the afternoon watching the tule wrens. No wildlife in the cove greeted methe place was quiet and apparently deserted. I waited ten minutes for a bird to perch on a cattail and begin its song. The only sound came from the striking of the rain drops on the foliage; the only motion was made as the drops stirred the water into rings. Then I thought: if the tule wrens, with all their enthusiasm for the place and all their zealousness in its defense, have temporarily taken to cover there is no reason for my staying any longer.

I put up the canoe and started for my car, but when I passed the stadium the sight of a few people at the ticket windows reminded me that a track meet was scheduled. I like track meets. Inaction and not weather had made me leave the marsh. There would be plenty of action here. Why not stop for awhile at the meet? I did.

I found conditions on the field as I had expected: puddles 


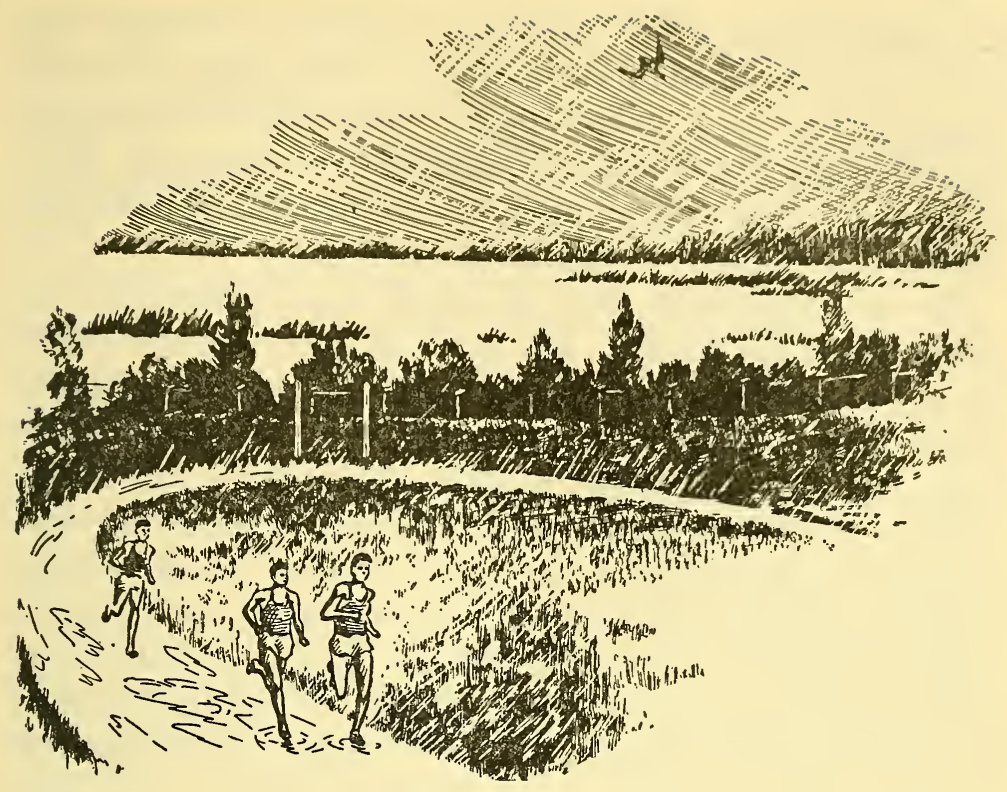

and strips of water covered the track, the runways for the jumps and pole vault were slick, and the weights and javelins required careful wiping each time they were used. The few spectators who had shown enough enthusiasm to come looked hopefully at the clouds, but the sight of gulls drifting in strong southwest air currents made me quite certain that the rain would continue and the wind strengthen.

I stood near the top of the stadium so that I could see in all directions. The open end faced Union Bay, the east end of the ship canal, and Lake Washington with which the canal connected. The foreground view was clear enough so that small things such as children's scooters on the lawns of the residences were plainly visible, but the distant view was shut off and a visitor would have no idea that beyond were the foothills and the Cascade Range. Small power boats constantly moved along in the canal, and just before the meet a hardy oarsman in a trim single scull rowed rapidly along in 
the squall of rain which struck him. It was becoming a day that waterfowl liked, and through my field glasses I could now and then see a mallard or the white and black color of a bufflehead, and once I distinguished the imposing flight of several Canada geese, probably the five which had been resting for the past ten days in Gadwall Cove.

The few spectators near me made uncomplimentary remarks about the weather, but rain and wind did not bother me as I was dressed for the colder work of paddling. Nobody would have chosen this sort of a day for a track meet. Maximum speed and strength in sport are possible only when weather conditions permit perfect control of body temperature, and when there is no undue chill to affect heavily strained muscles. Nevertheless, the practicing track squads made the best of it: they threw the javelin, put the shot, pole vaulted, and jumped to get the feel of the track and of the day. Runners in their heavy sweat outfits, necks protected by a towel, kept in motion. To chill was serious.

I looked around the stadium. I knew it well for I had lived in the city a long time and had gone to football games when I was a boy in grade school. And during the past year I had learned about the stadium's internal structure, too, for the man in charge of the various athletic fields had taken me through the tunnels and underparts of the construction to show me how many birds nested there-swallows which had daubed their clay brackets, rude but useful nests, in the niches and even on the light globes. There they raised their young and emerged to feed over the fields and water, a choice which ordinarily insured them an ample supply of food. The wild things had not been hesitant in using these athletic grounds for their own purposes: the baseball field as a parade ground for gulls in winter, the roof of the athletic pavilion for a place of assembly when snow covered the ground, the sides of the building as a nest site for cliff swallows, and the stadium recesses as a summer home for barn 
and violet-green swallows. The birds came without invitation, they adapted themselves to conditions and, if unmolested, remained.

The few spectators present when the meet began would not have filled one of the thirty sections. The first call was for the javelin, the shot put, and the mile run. I recognized the local University men who gathered at the stations for I had seen much of them that spring. Construction work in the stadium had required the removal of the fence on the bay side so that my walk to the canoehouse took me directly past the field where the track squad, all clad in garments much resembling the fleecelined underwear worn by their granddads (and grandmothers), practiced daily to perfect themselves in their various specialties. Once in the habit, I seldom failed to stop and watch proceedings. I liked the various field trials and the attitude of the contestants. Their patience astounded me: imagine the infinite perseverance required to spend hours in properly grasping the discus, in extending the arm and pivoting with just the proper speed and motion so that, when the turn was completed, the weight could be directed and propelled with that extreme. perfection of form which would add the few feet or inches necessary to eclipse competition. I used to watch the runners in their starting positions, feet against the blocks, body bent, fingers at the line, each muscle and nerve tensed for an instantaneous getaway at the report of the gun.

I liked particularly to visit the track after a few hours in the marsh. There I had seen creatures whose great concern was with the maintenance of life and whose satisfactions were part of that concern. Perhaps my day had been partly devoted to watching a mallard hen lead her $\mathrm{V}$-shaped convoy along the margins of the cattails, excitedly reminding a laggard duckling that the only safe place in the entire canal was directly behind her. She worked eighteen hours a day to bring up her brood properly and safely, but as I began to 
recognize each little family group and saw the shrinkage from an initial start of around a dozen down to ten, then to seven or eight, and finally to only five or six trailing behind her I realized that, while most people saw just the sentimental picture of a duck and her happy little family, its upbringing was grim business which bore heavily on the young.

On the track and at the field events I met entirely different conditions. There the competition did not concern itself directly with life but with the sports of life. There the contest was for the purpose of satisfying man's desire for physical supremacy-his wish to run faster, to hurl the javelin farther, or to jump higher or a greater distance, than his competitor.

I had only to look about the field that rainy day to justify this comparison between the track and the marsh. The cliff swallows fluttered about and dipped into the damp clay to obtain material for their nests in the window niches of the athletic pavilion. Directly in front of me runners practiced starts, so there was a continual bending and starting, bending and starting-a continuity of effort not connected with subsistence but with the hope that the resulting skill might enable them to beat their competitors, if only by a split second. Just outside the fence, a pair of newly arrived flycatchers sat on the tops of two willows and hurled themselves into space, not to break a record, but because they had a void in their tummies which they wished to fill.

A slightly freshening wind brought in an increasing amount of rain as the three milers-one local and two visitors-pulled off their sweat shirts and stood in their shorts and track shirts. I wondered how those cold rain drops and chill breezes affected them. The gun sent them down their lanes with a splashing that could have been mistaken for the beginning of a swimming event. The fit and condition of track shoes must have been an important factor on this day for the first few strides on sodden ground filled them with moisture and made traveling difficult. I noticed that one of the men, ap- 
parently to forestall any accident, had taped his shoes around the insteps.

The runners had ticked off one lap when I heard a voice at my side. I turned and saw a young engineer with whom I frequently played golf, the one friend I might have expected to run across on such a day, a fellow who considered it a crime to spend the week end anywhere but in the open. He was a man who concentrated on golf for his own exercise, and on the competitive games of his old college for the rest of his diversion. A waterproof hat and an army raincoat completely covered him.

"I thought your contract called for all Saturday afternoon in the marsh," he said jokingly. "What are you doing here?"

I watched the runners, still closely bunched, round the second lap. Then I replied:

"There's not enough activity to justify canoeing in such weather. I can use my glasses and see most of the marsh population from here."

The uniforms of the milers turned to dirty gray and then to black. Mud covered their legs and track pants. A visitor led, another followed, and then came the local man still in his stride but with an ever-widening gap showing that he was at the top of his capabilities. And that is the way the race ended.

My friend philosophically accepted the outcome and quoted records to show that it was to be expected. He knew the local, state, and northwestern records for the event. His memory was as sharp as a quiz-kid's. He knew the home towns of the runners and much about their high school history. He said:

"This is only one event. Wait till our boys get going." Then he added: "Why do you waste so much time in those bulrushes? You won't find anything like this in your messy marsh."

The javelin throw had begun at the east and open end of 
the stadium. The shafts sailed out in a long flight and quivered as they struck. The distances seemed great though I was too far away to judge adequately. One shaft pierced the sod in a location which I recognized, so that, without thinking, I said:

"That javelin landed just where we found the young killdeers last year."

"Where you found what?" asked my companion.

"Oh, some birds." I did not explain further.

In the quiet that followed I thought of the young killdeers. The old birds had built a nest the year before at the foot of one of the posts which stood close to the track used for the distance runs. A shallow depression held four spotted eggs, and for two weeks the birds had feigned distress or cried in anger so vociferously that almost all of the hundreds who passed knew of the existence of the eggs. Nobody molested them. I was asked to photograph the new arrivals in the nest but their stay, as is usual with killdeers, was so short that they had left before we reached the spot. Knowing that they would not be far away, we searched the field, a quest which would have been in vain had the old birds refrained from swooping down each time we got warm. Finally the boy with me found them, tiny bundles of brown and white down with stout legs and enormous dark-colored feet. We put them side by side and took pictures. From time to time they uttered their thin peeps so loudly that the old birds circled and berated us. Thinking that the young would show better on a lighter background than on sod, I placed them on my handkerchief, a practice which invariably gets me in trouble at home, for the resulting stains are not calculated to make a laundress happy. Before we had walked ten yards after finishing the pictures the old birds had rejoined the young and all was serene again. It was well that the killdeers were not there while the javelins were flying, for a score of them struck within a small spot close to the scene of our discovery. 
The progress of the meet made my friend very unhappy. He said:

"It's a shame that the rain slows things up so. Nothing goes right in this weather. You might as well have stayed in the marsh."

But I didn't agree. I liked watching the way the men handled themselves in the bad weather. I never thought that races could be run so smoothly under such handicaps.

A mallard hen flew directly over the stadium. The crowd lifted imaginary guns and popped at the bird as the grade school boys slay imaginary rustlers and bandits with their imitation six-shooters. The duck moved on steadily and disappeared in the cattails directly east of the stadium where beavers had built and occupied a lodge. Between showers I could hear the singing of spring birds now in the area-redwings giving their full song from the reeds, a towhee monotonously repeating its short warble, and a white-crowned sparrow whose oh-gee-kitty-did-scare-me song was especially conspicuous because I was hearing it for the first time in the season. The violet-green swallows had ceased their twittering and vanished, probably because there was little insect life out in such weather. The white bills of the coots on the water showed clearly through my glasses. Rains did not disturb coots for they fed on bottom growth which they obtained by diving.

The discus throwers and pole vaulters went about their business, apparently little affected by the downpour. The home squad lost but my friend was not downcast. The running events, he said, would put us in the lead.

Gulls soared high above us. Perhaps a hundred of them slowly breasted the wind which seemed much stronger at that height. After they had progressed a short distance, they ceased flying and let the gale hurl them back to where they had started. Then they would repeat the process or swing in great circles which took them higher and higher. They 
were strong flyers with an instinct for handling themselves in such situations. It was not food but just the desire for flight which kept them out in such weather.

The hurdlers warmed up in different ways, then ran smoothly, cleared the obstacles with only a few attendant clicks, and finished with two local runners leading.

Above, the gulls continued their movements in the storm and I could hear the minor shrill of their cries. Only one upland bird, a robin, sang in the increasing rainstorm. The skies grew darker, the waves on the bay higher, and the single sculler had sought the shelter of the crewhouse. The spectators no longer looked for a break in the-downpour but clustered in one section like stock bunched and waiting for the pasture gates to open. My partner liked the way the meet was now going. Well protected by his rain clothes and happy that the home team was ahead, he made this two-edged remark:

"Some doings. You can't see anything like this in the marsh."

I figured that I had made a pretty good trade for such a day. The canoe would have been wet, the rain hard to buck. Soon I would have been damp and cold. In the stands I was dry, and by moving about I could keep quite warm. And so I remained, through the jumps, the two mile, and the concluding relay which put the local team forty points ahead of their opponents.

The crowd broke up quickly. My friend's last remark was:

"Rain or no rain, it's been a great day. I'll call you up for the next one. As I've told you twice, there's nothing like this in the marsh. You'll have to agree to that."

I did agree, but not in the way he thought. I had thoroughly enjoyed the contests of the afternoon, and my friend had a right to be proud of the local team's performance but, after all, compared to what I saw on every trip to the marsh it was the work of nonprofessionals. And as one of the great 
golf amateurs had said a few days before: the good average professional is about five strokes better than the good average amateur. The principle is true everywhere and the difference varies only in percentage. The men had performed with the maximum grace and skill to be expected from those who were not constantly spurred on by the relentless necessity for food and the successful avoidance of one's enemies. The performances I saw in the marsh were not by amateurs but by creatures which had practiced professionalism from birth. These wild animals were not like the collegiate amateurs who could, if they felt their inability to perform properly, still continue as a substitute or a member of a secondary team, or even quit altogether. There was no substitute for efficiency in the marsh, no place where the inefficient could go, no hope that it could exist on a plane lower than that of the others of its kind. Inefficiency meant the quick extinction of the individual, the loss of its life through alert predators, or it meant starvation through inability to compete for food and territory.

I thought of the high hurdlers who had put on such a beautiful demonstration under the trying conditions of wet winds, water-covered lanes, and slippery footing-everything that could be expected under the standards of men, but not to be compared to the ordinary daily feeding evolutions of the black swifts whose food is taken entirely in flight. Their life away from the nest is given entirely to the executions of tremendous swings, abrupt turns, and all the other maneuvers necessary for the capture of fast-flying victims. These birds spend their active life in this pursuit, travel hundreds of miles each day with a skill that I have never seen excelled by any other thing, and stop only to feed their young or when night prevents further hunting. They are professionals whose life depends on their athletic ability.

The marsh can present nothing exactly like the powerful throw that had won the javelin event, but what would my 
friend have thought of that living javelin, the kingfisher, which regularly launches itself from considerable heights to pick up almost certainly the minnow beneath the surface of the water? And there is that self-guided bomb, the osprey, which can drop from heights of a quarter of a mile and strike the fish necessary for food to maintain itself and its family.

As I walked along to the gate I watched the contestants, the home squad happy, the visitors downcast, not so much by the defeat as by the fact that they had been badly outclassed. Fine looking fellows all, strong, intelligent, and in splendid condition. But it was their intelligence and not their physical ability that made them superior to the birds and the wild mammals. My friend had been right when he said that I would not see anything in the marsh like the contests I had seen in the stadium. Grace, as demonstrated by the animals, is unknown to man. Man is physically incapable of duplicating the speed and accuracy of such movements as the spring of the mink, the dive of the otter, the right-about turns of the weasel, the jumping ability of some of the mice. Perhaps in the ages when man had been forced to depend for food and survival on physical adroitness, he, too, had been an athletic professional adequately using his own physical equipment to compete with other animals. But he has depended more and more on mechanical contrivances designed by his own ingenuity until now his speed can be surpassed by almost every creature in the marsh and his strength and ability are inferior.

On every trip to the marsh I saw spectacular skill demonstrated, not by sport-loving amateurs, but by professionals who must win their events or perish, sometimes immediately, but always eventually. When a Cooper hawk dashed into a flock of chickadees there was no opportunity for them to warm up for the getaway, to place themselves in specially prepared positions and in convenient starting devices. An 
immediate start was essential, not to win cups or for the cheers of the spectators, but to save the life of the starter. The hawk, to live, must have a victim, and that victim would be the bird which in its training had failed to attain the wariness and speed necessary to avoid this constant menace by a predator which made its attack doubly efficient by surprise and high speed. It was penalties such as these that made professionals of these marsh contestants. 


\section{Introducing Something New.}

\section{0.}

ONE DAY WHILE IN THE MARSH I speculated on the many methods by which species of plant and animal life could be introduced into the area. There is no isolation but, on the contrary, entry is possible by a dozen methods: an extensive Arboretum containing plants from all over the world borders one side of the marsh, many fine private gardens touch the lake so that cast-off plants or seeds might easily be wind-blown or water-carried. Salt water is reached by the short ship canal, streams enter the lake, a railroad skirts the shore, foreign and domestic ships pass right through the marsh area. The ten dozen or more species of visiting birds might bring in seeds. The possibility of new introductions appears unlimited, but in reality there have been so few that it is possible to discuss them in one chapter.

Even if the song of tule wrens had been absent on the day I made these notes, the commotion I found in Gadwall Cove would have informed me that the season was spring. The condition that existed there was caused by one of the introduced species. Motionless trees and bushes and the quiet waters of the open bay indicated the total absence of breeze, but from the shallows came the sound of water. Not the drip- 


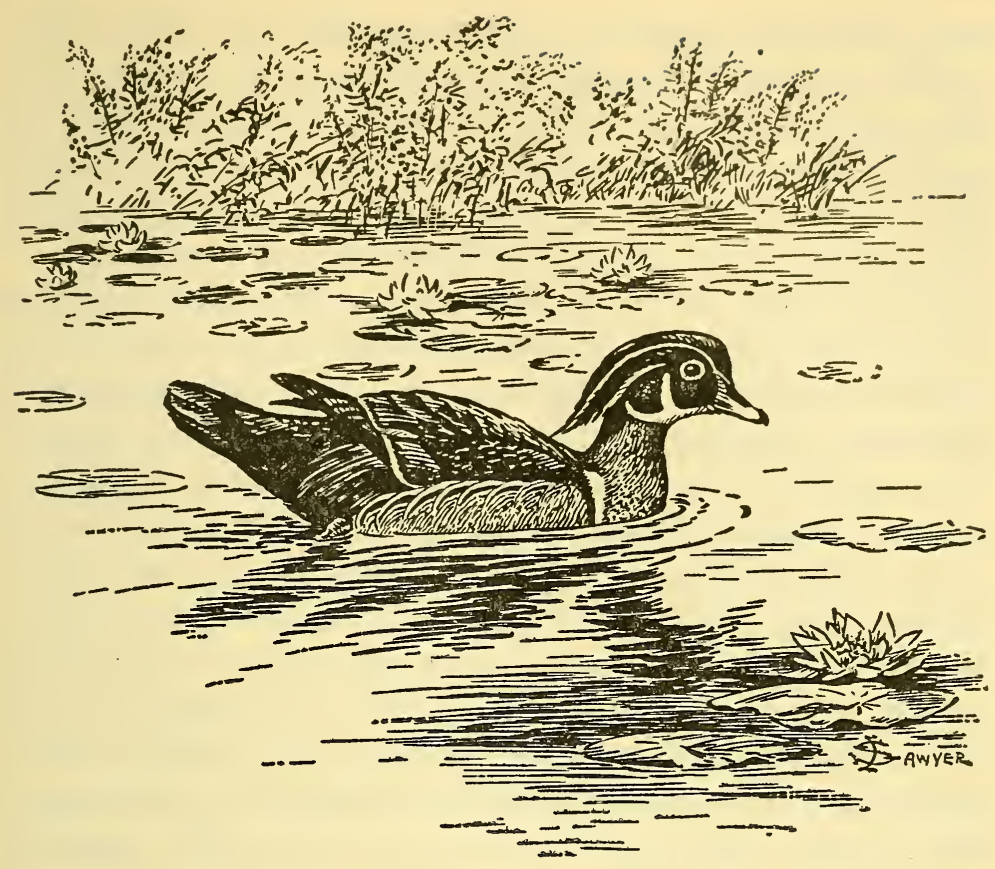

ping through the trees after a shower, or the gentle purring of water over stream riffles, or the sharp break of waves on a gravelly beach, or the light splashing of children as they built play houses, but a strange sort of intermittent action, now light and quiet, then heavier and accompanied by decisive sweeps which stirred the surface and put small areas into quick swirling passage similar to that caused by a strongly propelled paddle. The disturbances came not only from the center of the baylet but from the margins where the bulrushes pushed out into the water. If I looked in any direction and waited a moment I could see rushes put in motion by heavy objects which passed and stirred the soft ooze of the bottom into muddy whirls. Now and then a muffled blow struck the canoe and jolted it as if a small log had been hit. Wavelets, splashes, and water rings appeared 
and produced sounds of varying intensity and quality. The sounds vaguely resembled those which cattle made when they crossed shallow water, but there were no animals to be seen. Strangely enough, the splashes and movements had little effect on the ducks, coots, and grebes, and only when the activity came very near to them did they move away.

I knew that this commotion often went on in spring for hours at a time. I never observed that the time of day or weather conditions affected it in any way. The presence of the canoe was ignored if it moved slowly, but if I stopped the activity close to me also stopped. The cause of the disturbance would not puzzle a newcomer for long, because at irregular but frequent intervals I saw the exposed upper surfaces of heavily built fish whose clumsy structure, brownish-yellow backs, and coarse scales were those of the species known as carp. They threshed about, ran alongside each other, ploughed through the reeds of the shallow water, sometimes submerged, often partly exposed, but always stirring up the mud and throwing water with the powerful sweep of their tails. Frequently a third of their bodies showed as they moved along, and at other times only the movement of the water indicated that they were still in the vicinity.

By then their purpose was apparent to me, as it would have been to any other observer. They were there for their annual spring spawning; the females were depositing their eggs; the males were fertilizing them with their milt as they were laid. This was the annual gathering for the purpose of perpetuating the species. All energies were concentrated on this particular phase of their lives. Feed and rest would be forgotten, and until the egg depositing was completed the shallow spots of the marsh would be the scene of activity which would begin slowly, increase to a stirring maximum, and then abruptly die away. The older fish would leave, the young would be hatched in this shallow water where they would be comparatively safe from most of their enemies, and 
although there would be considerable mortality among the new arrivals, enough of them would survive to leave a comfortable margin. As they grew older, the young would seek deeper water and begin to compete with the varieties which the anglers consider more desirable.

I must here confess that the carp is one of the few fish against which I am prejudiced. This is not a scientific judgment but a personal one. They are not a native fish, nor are they native to Europe from where they came to us, but originated in Asia. There is usually some appealing attribute in almost every living creature: courage, beauty, gracefulness, gaminess, or the like. But I find all of these lacking in the carp. I think my early experience had something to do with it. I first saw carp in the East where newly arrived immigrants used to cut pieces of potato for bait and fish for, and catch, many carp where foul sewers entered into streams. The fishermen were glad to catch the fish and apparently esteemed them highly. And although the fish may have been excellent I have never seen even a picture of a carp without visualizing the sewer at the foot of State Street in the little town I used to visit and the sight of these fish as they were pulled from the filth below. Aside from my distaste for what was apparently one of their preferred habitats, I did not like their coarse dirty appearance or the fact that, as compared with the perch, bass, trout, pickerel, and other middle western fish we considered desirable, they were ugly and shapeless. The carp has always been considered a coarse but popular food and mention of the fare of the Romans and of the Middle Ages seldom excluded this fish. The lakes and the ponds of the noblemen and the monasteries were well stocked with it, and since it is sturdy, easily adaptable, and exceedingly tenacious of life, it has probably supplied much highly esteemed food to the people of the world. But in the United States it has been accepted by few as a good table fish. Its introduction therefore has proved to be a mistake because in 
many cases it has replaced the more popular native varieties. Indeed, the history of these fish in the United States has always appeared to me to be a potent argument against the bringing in of foreign species. Excepting for the importation of the European (Hungarian) and the chukar partridges and of the ring-necked (Chinese) pheasant, which three are generally conceded to have been unobjectionable, I can think of no other introductions that have not been fruitful of evil. Had the carp been confined to land-locked areas where it could have been absolutely controlled and where native fish did not do well, then it might have been a valuable contribution to low-cost food. But it possessed the vitality and stamina of many imported species and, once put into our waters, it has spread over a vast area where, as it is not well regarded as food and has no beauty or other value, it has become a real pest. Certainly it has no place in the streams of the Pacific Northwest which are capable of raising salmon and trout and bass. Nevertheless, it now infests many such streams. It has not only affected the supply of food for game fish but it has, particularly on the Columbia River, destroyed much bird food. It has the pig-like habit of rooting up the bulbs of certain of the water plants, and to such an extent that, in some localities, the wild fowl have curtailed or ceased their concentrations due to lack of suitable food, plentiful before the arrival of the carp.

This is but one illustration of the folly of unwise introductions, a practice which has been followed by national ill results. The shipping of the jack rabbit from the United States to Australia, the muskrat to Austria, and the English sparrow and the starling from England to the United States has had most unfortunate consequences. The gypsy moth, brought from the Old World to America in an unsuccessful attempt to produce silk, ended as a terrific tree pest. The bringing of the coypu from South to North America is a recent event which promises to be a mistake of great im- 
portance. All of these transplantings were done with high purpose, but all are living examples of the evil consequences of the importing of an animal without the long-established checks which keep it in its proper place in the country where it originated.

The small number of these new species perhaps justifies the conclusion that these introductions are not so simple as they might appear. The dropping of seeds by birds does not necessarily mean that the seeds will establish themselves. They must land in the proper places and in soil in which they are fitted to grow. Even in favorable spots they may be picked up by rodents or birds, or washed away by spring rains, or carried beyond the water depths they can tolerate. If they succeed in sprouting, the well-established vegetation about them may choke them promptly or the tender growth may be eaten by animals which overlooked the seed. Seeds which enter the area by floating may be obstructed by aquatic growth and never reach land. Success for one season does not mean that the plant will continue to grow. It may fail to set seed, the seed may be washed away by the fall rains or eaten by the busy nesting birds. and their young. The whole plant may become part of a muskrat's meal. It has been said that not one trial in a thousand or a million will prosper-the only answer is that there are enough thousands or millions of trials so that now and then one does succeed.

I do not refer to the dozens of plants which I have seen bloom for a year and then disappear, nor do I have in mind the weeds which are everywhere and which invade all new or burned-over ground. The system of seed dispersal of these invaders apparently is so effective and their tenacity so great that their appearance, growth, and survival can be regarded as almost a certainty. The marsh also displays each year new pinks and blues and whites, obviously garden escapes, which have enough pioneer spirit to make a brave start but lack the strength and adaptability to endure. 
I refer to established introductions only, those which apparently have become a permanent part of the marsh flora. In the period I have been a marsh observer I have watched the extension of only four such plants, the history of which may prove to be of interest.

One of these plants, bird's-foot trefoil, is a member of the pea family and originally came from Europe, first arriving in the eastern states and later here. Its pleasing yellow, or yellow and red, flowers grow on numerous stems which come from the same root. The leaves are divided into three leaflets. The plant is a perennial and, once started, is hard to stop. Whether it spread overland to the West from the East or whether that important method, ship's ballast, brought it directly to the West from Europe is not known. Neither have I been able to determine how early it appeared in other parts of the state. One spring I found a plant or two on the banks of the ship canal in the marsh. When I checked it and found that it was an extremely troublesome weed with the habit of dominating much of the territory it entered, I determined to uproot it and see if it were possible, by early action, to keep it out of the marsh. I pulled these first plants, but when, in the following spring, I found it in a dozen spots, and learned that it was established elsewhere in the state, I made no further attempt to control it. One botanist refers to its habitat as "Waste places, in a few instances invading fields." This would place it as a plant of wide tolerance because in the marsh it grows in places which are submerged for a few weeks or more in spring. I hear sometimes of its establishment in other districts, and doubtless we of the marsh are about to witness the invasion of a plant, which, although rather pretty and unobjectionable at present, may become extremely annoying in certain places.

Another plant whose entry I have observed with more complacency is the yellow or sword flag, an iris with leaves wider and of a lighter green than those of a cattail. The 
flower is bright yellow with a delicate texture. A native of Europe like the trefoil, it is of more aristocratic origin, for it did not arrive in steerage but is unquestionably an escape from the gardens of Seattle where it has been cultivated. My attention was first called to it by a botanist whom I was taking on a tour of inspection of the marsh. On this early spring day the cattails were still brown but the much broader leaves of this iris formed a clump which stood waist-high and green. It brought forth lovely flowers a few weeks later and my friend placed it as Iris pseudacorus, a native of the Old World. Its subsequent history shows clearly the hazards of such casual introductions and the narrow margins which lie between failure and success. A short time after it bloomed, the muskrats found its leaves to their liking. Before they had found other equally, or more, palatable food they had left so little vegetation that the plant seemed doomed. Yet it put out more leaves and began to grow and prosper until the heavy fall rains raised the lake level sufficiently to pull its roots nearly out of the bottom, with the result that when there was a breeze it would rise and fall with the waves as if it were floating free. In some way it again became anchored firmly, successfully survived the winter, withstood another attack of the muskrats, flowered plentifully, and since then it has increased in size until the plant or group of plants is now more than a yard in diameter. This year I have discovered, with much pleasure, that there are now three more stations so that the chance of its complete establishment is much more certain. Only one thing might prevent this handsome yellow iris from becoming a permanent decoration in the marsh-it is the first green to appear in the area and as such it may be attacked severely each spring by the muskrats.

Another type of introduction, though less interesting than the two preceding, was used in establishing the water lily in the marsh. The canoehouse manager informs me that these introduced lilies came from a small artificial basin of water 
on the campus, called "Frosh Pond" because it was frequently used for "dunking" freshmen. Lilies which had been put into this pond so clogged it that they were all cleaned out and dumped on the edge of the bay, from which many of them were rescued and planted by the manager. They started slowly, possibly because they were raided by the muskrats, but some of them held on, and now they fill the spots considered most suitable and many other areas as well.

We thus have three growing adventives in the district, each of which has arrived in a different way-the bird's-foot trefoil probably in ballast, the iris by escape from cultivation, and the water lily by direct introduction. Each promises to play an increasingly important part; each, though the process may not be apparent to the observer, is unquestionably competing with other marsh plants.

A fourth plant, the loveliest in the marsh, has a local beginning which is not altogether clear. In spite of its impressive beauty and extremely wide distribution, nobody appears to know how and just when it became established in the area. The plant is known as the purple, or spiked, loosestrife, and it now grows in swamps and wet places in many states of the northern half of the United States. It is not native to the United States but came from Europe where it is widely distributed and well known. It was established in the eastern states and Canada long before it was known here. It may have come to the West Coast from Europe or from the East. There were only small patches when I first began canoeing there, but now, next to the cattail, it dominates the area so that in the blooming season the purple of its foot-long spikes actually obscures, in many places, the foliage of the cattail. The stems of this plant are square, or almost so, the leaves opposite, or sometimes in whorls of three. The plants stand, sometimes on wet ground, often in water a foot deep, and massed so that their blooming frequently displays as much as an acre of dark brilliance, set among the green of the cat- 
tails. The drastic lowering and raising of the lake exceeds the tolerance of the plant so that the margins constantly recede when high water has been prolonged, and they return when a lower level is maintained.

These examples show that plant changes, though infrequent, do take place in the marsh. But what about the mammals? Are the changes of equal significance? I know of three. One had taken place before my arrival, another occurred in the past few years, while the third, if it has not taken place already, will soon come and will greatly affect the local mammal economy.

The first change, which affected the marsh and every other area where it took place, was the arrival of the Norway, or brown, rat. We do not know when this creature came to the Northwest but we know how it arrived, for it was a traveler and a constant, though unwelcome, guest on ships. It may have been unloaded in material shipped to this port or it may have walked ashore under its own power. Once here we may be sure that it increased rapidly in numbers and began its history of destruction. In considering this pest we have the satisfaction of knowing that it came of its own volition and was not introduced because somebody thought that it would become a good house pet or that it could be used as a check on some greater pest. There is little good about the brown rat, for when a creature is at once a carrier of serious diseases, a destroyer of tremendous quantities of raw and finished material, a predator on many useful wild and domestic birds and mammals, and withal a foul and unclean animal, there seems to be nothing left in its favor. Locally, it overruns the marsh and is probably its greatest predator, doing much damage to the eggs and young of the ground-nesting birds.

The second mammal is the beaver, once a resident of the entire Northwest, then almost eliminated by overtrapping, and now increasing in numbers. Its increase will pose many problems in its relations with man. Its establishment in the 
marsh may be only temporary, for as soon as the unprotected trees are consumed it must move to other localities, or so change its food habits that it will eat the smaller vegetation of the marsh. It will be interesting to watch developments.

The third mammal is the coypu, a rodent brought from South America with the intention of producing its fur, known as nutria, on fur farms. For some reason the quality of furs produced in this section has not compared favorably with that produced in its native country and the furs did not bring prices sufficient to justify the maintenance of the industry. Animals have been released or have escaped. Now they are beginning to appear in many places and the reports received indicate much trouble in the future. They are said to be raiders of domestic gardens and to be most destructive; they do harm with their bank tunneling; and they may displace the comparatively inoffensive muskrats which have long been residents. Reports about them come in from new sections, and it is feared that they will soon become a serious factor for evil since they have been seen and have become established but a few miles away.

As could naturally be expected, the greatest local changes are in the bird life. There has been a steady shifting in the register of marsh bird residents. Much of it has been due to the increase in population in the district and to the different conditions produced by that increase. The sooty and ruffed grouse, once common, left when the trees were cut. The bluebirds and the woodpeckers have thinned out for the same reason. The creepers and such visitors as the Townsend solitaire are practically never seen. The Canada jay, the camp robber of the lumbermen, has retired to the timbered hills.

But all is not on the debit side. The California quail and the ring-necked pheasant are heard in localities that used to echo the spring hooting of the sooty grouse and the drumming of the ruffed grouse. These birds find good shelter-the 
pheasants in the brush-covered portions of the marsh and the quail in the woods on the nearby hillside. The green heron may be considered the most significant of the new visiting species. The increase in the number and size of the cottonwoods and willows probably accounts for the many flycatchers whose spring singing may be heard over the marsh. The russet-backed thrush has also been attracted by the tree growth, but the meadowlarks which once sang at the north end of the bay ceased their visits when the meadows disappeared. Each decided modification in the character of the habitat produces some change in the birds which regularly use it.

The shifts in the duck populations cannot easily be explained by mere change in habitat and have greatly puzzled me. The increase in the number of baldpates has been so marked that they have been a source of mild annoyance to shore residents whose lawns they sometimes invade. The wood duck, unreported in the area for years, was seen again six or seven years ago and has been known to nest during at least two years. It is my hope that residents on the lake will build nesting boxes for them. The blue-winged teal, small and handsome, and a rare visitor from east of the Cascade Range, nests yearly. The shoveler, or spoonbill, the duck with the huge bill, rarely seen in summer in the marsh, gives some evidence of breeding here, for three pairs of birds were seen during the last summer, although no young were reported.

All of this has been taking place in spite of the fact that the area of the marsh is constantly diminishing through the dumping of dirt and other material. A decrease in nesting could be expected, but even the ever-present mallards have shown no tendency that way and I have seen more young broods than ever before. I am puzzled to know whether this is just a local matter or whether, in some degree, it represents general conditions. I would like to be able to give a positive answer to questions such as these: Is the pressure for wild- 
fowl nesting grounds getting a great deal more serious? Is the nesting experience on protected areas better than in the wilder but less protected areas? Will some other species tend to nest closer to civilization as do our mallard and the eider ducks in Scandinavian countries? Is it possible that there might be an increase in the number of nonmigrating waterfowl such as are now represented by the partly domesticated mallards and by the Canada geese of our local Woodland Park which stay year after year even though they have not been pinioned? Are geese and other waterfowl accumulating a memory, knowledge, or instinct which enables them to avoid the shooting areas and to stop at the protected spots? These are but a few questions which local conditions bring to my mind.

The changes continue as the years pass. Some might be foreseen if I were familiar with man's plans in the areaplans for the lowering or raising of the water depth and for the revisions of the marsh boundary. Some innovations will be insignificant, as the appearance of a new and tiny blue flower, or of an eastside turtle which could not be accounted for until it was learned that it had been brought over by students for laboratory examination and afterwards released.

Occasionally, quite accurate prophecies can be made. Right now, the arrival of a new and rather undesirable bird can be predicted. It is the starling. Various observers have marked its progress as it, like the pioneers of the early nineteenth century, steadily pushed out for the West. It was seen in eastern Washington and only recently one of the most reliable of our local field men has recorded it in the little town of Bellevue, less than ten miles distant. We will not welcome it any more than we welcomed the bird's-foot trefoil, but like the trefoil, it will be here to stay, and we must be witnesses to the effect, good or bad, that it will have on the local bird population. But mankind cannot complain for it was man, 
filled with the conceit of man, who brought it from Europe to this country. And, after all, the white man himself is as much an introduction to the bay as the coypu, the trefoil, and the rat. 


\section{Arrowhead, Squaw's Toes, and Other Things}

\section{DifFerent ASPECTS OF THE MARSH}

came to my mind from time to time. Some I had mulled over often but to others I had given little attention. One of the most insistent concerned the value of marsh products. How much were they used and for what purpose? It appeared an interesting nook to explore.

I was in the canoe and was just finishing a morning tour of inspection of the marsh, a two-hour progression which gave me a comfortable workout and took me to every nook I wished to look over. Quiet normalcy marked this late July day. I saw no newcomers, but when I heard the repeated kidick call of a Virginia rail I turned to my old standbys, the summer residents. This small bird, in spite of its qualifying name, is found over much of the marsh territory of the Pacific Northwest. The sound came from directly opposite the canoe and challenged me to play a game of which I never tired. Somewhere in the shelter of the cattail stalks stood a ten-inch reddish bird with a long and rather slender bill, a bird whose browns and grays blended well with the marsh vegetation, a bird which preferred to skulk and hide rather than fly, and which only occasionally came out into 


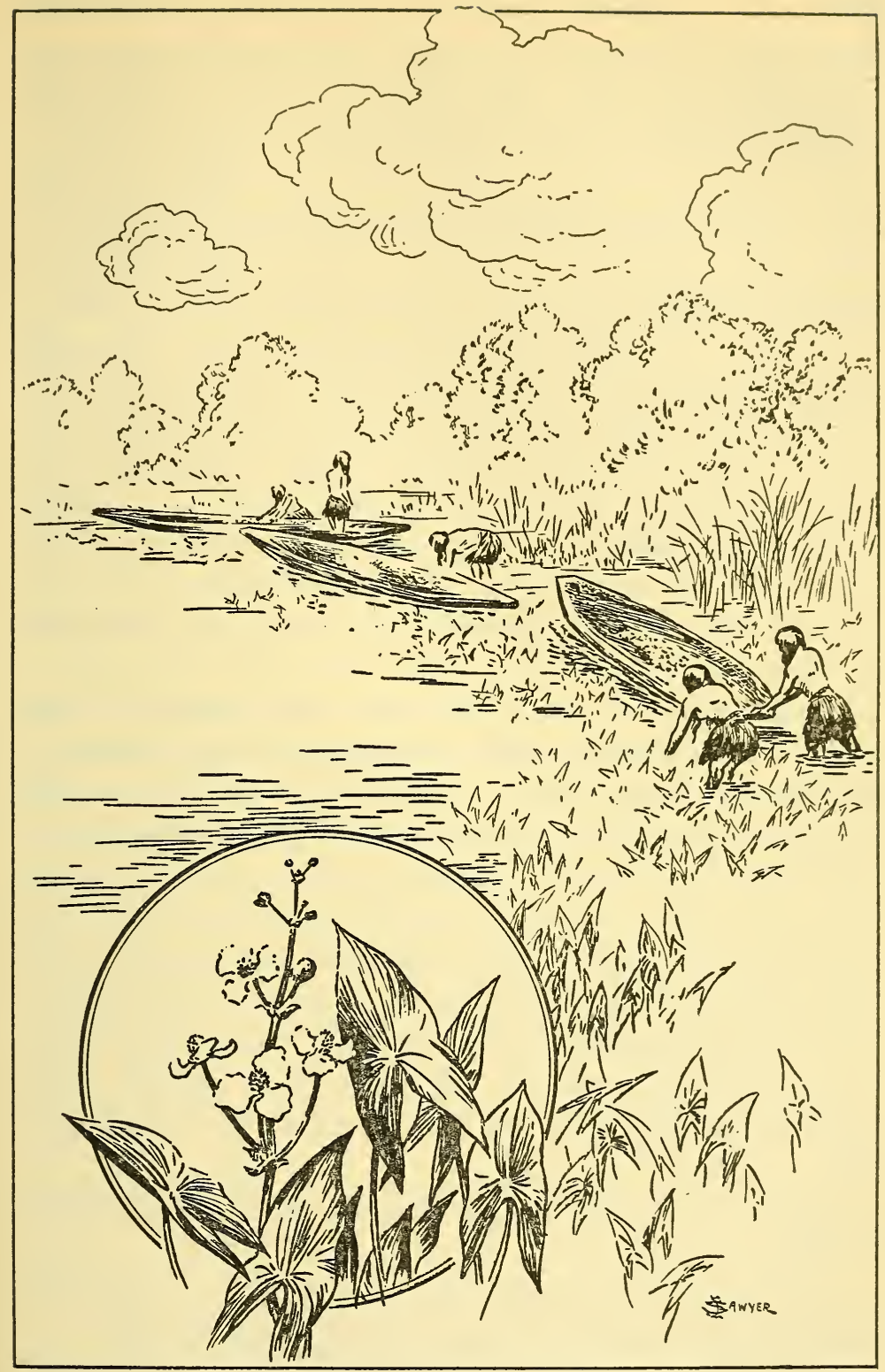


the sunlight of the marsh margins. My part in the game was to sit quietly and scan methodically the spaces between the cattails until often (though not always) I located the shoebutton eye of the rail and then traced the outline of all its parts which were not blocked out by the intervening growth. Often when I discovered the bird it was just inches inside the margin; sometimes it was in the very last visible depths of the tangle. Although I frequently gave up the search with the excuse that the bird was not visible, I always knew that a black and beady eye was in the clear and watching every move I made. This time, after I looked continuously for about ten minutes, I could not locate it at all; even though the bird twice uttered a distinct note as if to guide my search. I had only one consolation: the tangle was so unusually heavy that the chances against my winning were about ten to one.

The growth on the bank was dense and so tall that I held up my double-bladed paddle as a measure. Eight feet separated the blade tips but the tallest of the cattails extended three feet above them. The leaves moved slowly in the breeze and rubbed with a soft continuous whisper. The bulrushes across the narrow channel reached higher than any I had ever seen and stopped just a foot below the cattails. In no other place in the marsh did the growth reach such heights. Only the closeness of the plants provided the support necessary to keep them erect. As I looked about I thought of the enormous tonnage of vegetation the marsh produced each year.

I spoke to the canoehouse manager when I returned to the float:

"You've been near marshes a good part of your life. Do you know any uses for all the stuff that grows in one?"

"Sure. When we were kids in Minnesota, we dipped cattail heads in coal oil and used them for torches. They made a 
good light. In the early days, when there were lots of Republicans, they used to carry them in torchlight parades."

"That probably didn't exhaust the whole marsh capacity. Anything else?"

"We put up marsh hay. It was pretty good feed."

"Is that all?"

"We gathered wild rice. It was tops in duck and goose dressing. I can't think of any other uses."

It was a start, but only a start. Marshes had existed through the centuries. The ancient civilizations must have looked to them for many things. On the way home I remembered the biblical story of the daughter of Levi who, when she could no longer conceal the infant Moses from the Egyptians, put him in an ark of bulrushes which she laid by the riverside. Pharaoh's daughter rescued the weeping child and turned it over to a Hebrew nurse to raise. I wondered just how an ark could be made from our stiff and unworkable round bulrushes, but when I consulted a Bible concordance I learned that the plants referred to were of the papyrus species, with triangular stems. I found a translation of a work on plants by Theophrastus, a Greek philosopher who died about 287 B.C. There I read that the papyrus had many applications other than for a cradle to house an infant Moses. It was used for boats and their sails, for mats, covers, and clothing, for ropes, and for many other things of which paper probably was the most important. Theophrastus wrote of a lotus, the Nile water lily. When the sun set the lily closed, as does the water lily in our marsh, but our lily lacks the remarkable habits attributed by Theophrastus to the blossom of the Euphrates species which, when it shut up, would go under water till midnight, sinking to a considerable depth so that it was below reach of a man's arm. Then it rose with the dawn and opened as it appeared above the surface of the water. The people collected and pounded the seeds and made loaves of them for food. The lake of Orchomenos grows a kind of 
reed which was used for making pipes and the author described in detail the process of fashioning them.

I consulted a translation of the Natural History of Pliny the elder, a Roman who lived about the time of Christ. His information about the use of marsh plants was not extremely revealing but it required a whole week's reading to loosen my grip on the book. During that time I ran wild among such subjects as the evil habits of the goatsuckers, the trade in trained nightingales, the intelligence of dolphins, the ortalons, diving for pearls, and the locust. Some of the information was fairly accurate but much of it was as fantastic as the fairy stories I had read as a child. The locust, according to Pliny, could move sidewise because it had feet. The locust mothers die when they have given birth to a brood. A maggot, which immediately forms in the region of the throat, chokes them. The males die at the same time. Although the locust dies for such a trifling cause, it can, when it likes, kill a snake by gripping its throat with its teeth. He spoke of locusts in India which were three feet long with legs and thighs which, when dried, could be used as saws. Among the Parthians the locust was an acceptable article of diet.

I considered that this was a proper place to discontinue my reading of Pliny. Mankind appears to have the ability to exhaust the supply of any pleasing food offered it, and how could insect pests be disposed of more simply than by building up an appetite for them? The legs, of course, could be saved for saws.

In the meantime, a week had passed. That was the trouble with curiosity, I reflected: when I began an investigation of even a thing like an ark to hold a child, it often meant a search of hours. I did not withdraw but resolved to investigate the use of marsh products further. I recalled some discussion of marshes in a book on the thirteenth century. There was the use of water cress for the table, the construction of fire screens and of numerous containers, all of osier. In the 
halls of the nobles, the floors were often covered on feast days with rushes mixed with flowers and sweet-scented herbs, the delightfulness of which was sometimes marred by the failure to remove them until they were foul with the accumulated rubbish which had dropped from the tables.

Gilbert White, who wrote The Natural History of Selborne in the last quarter of the eighteenth century, reports the use by the residents of his district of rushes for candles. They strip the rushes of all but one or two ribs of surface material which gives strength and prevents too-rapid burning. They bleach them next, after which they are dropped into hot fat or grease. Rushes so prepared give a good clear light and a piece a little more than two feet long will burn an hour. He also mentions the use of a well-combed moss which he says "is very proper for the dusting of beds, curtains, carpets, hangings, etc."

As time passed I became acquainted with many interesting facts. The first specific mention of marshes in the Pacific Northwest was made in 1792 by Archibald Menzies in his journal. While he was on the north shore of one of the San Juan Islands, he met Indians who were gathering marsh materials for winter use. The passage reads as follows: “. . . we passed a low extensive Morass well cropd with Bullrushes of which large patches had been plucked by the Natives \& were now laid neatly out upon the Beach to season them for making their Mats. ..." These mats were woven during spare times in the winter and were made for a wide variety of uses.

I found that Fort Nisqually, one of the early Hudson's Bay Company trading posts, had been built close to low and marshy country at the mouth of the Nisqually River about fifty miles from Seattle. The company journal was detailed enough to specify any marsh products if they were being used, but all I could find mention of was the cutting of nearby trees for firewood, spars, and building material, the 
grazing of stock on the marsh hay, and the extensive picking of berries by the Indians. A journal entry mentions the employment of one man "to mow rushes to be used in thatching houses if no better covering arrives." The attitude toward rushes as a roof cover is evidenced by a later entry indicating that cedar bark had been adopted for that purpose. There was little evidence that the first white settlers had been able to derive much benefit from marsh products in spite of the fact that the natives made constant use of them.

My inquiries were neither intense nor according to a definite schedule. When a desire came to me to know about the cattail, the heaviest producer in the marsh, I read here and there among the ancients, the medieval herbalists, the journals of settlers and explorers, and the exploring botanists, until I learned something about it. John Gerard, who wrote the sixteen-hundred-page volume, The Herball, published in 1636, had this to say of "Cats-taile":

Cats-taile hath long and flaggy leaves full of a spongeous matter or pith, amongst which leaves groweth up a long smooth naked stalke without knot, fashioned like a speare, of a firm or sollid substance, having at the top a browne knop or eare, soft, thick, and smooth, seeming to be nothing else but a deale of flocks thicke set and thrust together, which being ripe turns into a downe and is carried away with the winde. The roots be hard, thicke, and white, full of strings, and good to burne, where there is plenty therof to be had. . . .

Of this Cats-taile Aristophanes makes mention in his Comedy of Frogs where he bringeth them forth one talking with another, being very glad that they had spent the whole day in skipping and leaping inter Cyperum of Phleum, among Galingale and Cats-taile. . . .

\section{The Vertues.}

The soft downe stamped with Swines grease wel washed, healeth burnes or scalds with fire or water.

Some Practitioners by their experience have found, that the downe of the Cats taile beaten with the leaves of Betony, the roots of Gladiole, and the leaves of Hyppoglosson into pouder, and mixed with the yelks of egges hard sodden, \& so eaten, is a most perfect remedy against the disease in children ... when the gut ... is fallen into the cods. . . . 
This downe in some places in the Isle of Ely and the Low-countries adjoyning thereto, is gathered and well sold to make mattresses therof for plow-men and poore people.

It hath been also often proved to heal kibed or humbled heeles, (as they are termed) being applied to them either before or after the skin is broken.

Dr. Erna Gunther, Director of the Washington State Museum, has furnished much information regarding the employment of cattails by the Indians of western Washington, and it is from her Ethnobotany of Western Washington that the following has been taken. Some of the Indians baked the roots and inner stalks for eating; the roots were eaten raw by others. But the cattail was much more widely used for matmaking than for food. Mats were made probably by most of the tribes in western Washington and served as hangings and screens inside the winter houses and as coverings for temporary houses and shelters in summer. They found additional use as mattresses, for kneeling pads in canoes, and for raincoats and capes. Some Indians made large wallet-like packsacks of cattails and lightweight baskets as well. Two-ply string, fashioned by rolling on the bare thigh, was made from carefully peeled cattail leaves.

From other sources I learned that some eastern Indians made a cake of the pollen, that cradles were lined with cattail down, and that the mature heads were used in the preparation of deerskins. Dozens of additional applications doubtless could have been found.

At first I did not check the value of the skunk cabbage, one of the earliest blooming plants in the marsh, because it seemed so worthless. Its leaves are large and coarse, its general appearance unattractive, and its odor decidedly unpleasant. Much to my surprise, I found myself quite in error. The Indians of the Pacific Northwest held it in rather high regard. As an emergency food the roots are said to have frequently saved Indian tribes from starving. The raw root 
is hot like pepper and was used for a "blood purifier" and for stomach and bladder trouble. The leaves made a healing poultice. The heated blossoms, when applied to a part affected by rheumatism, were said to bring relief. Some of the tribes rolled the leaves for berry containers or for drinking cups. Dr. Gunther reports:

A Quileute sealer puts some leaves under the bow piece of his canoe because the leaves are dead and flat and will lie still, therefore the seal will lie still too and be caught easily.

\section{She tells this about the plant:}

The Kathlamet Indians have an interesting myth concerning the skunk cabbage. In the ancient days, they say, there were no salmon. The Indians had nothing to eat save roots and leaves. Principal among these was the skunk cabbage. Finally the spring salmon came for the first time. As they passed up the river a person stood upon the shore and shouted: "Here come our relatives whose bodies are full of eggs. If it had not been for me all the people would have starved."

"Who speaks to us?" asked the salmon.

"Your uncle, skunk cabbage," was the reply.

Then the salmon went ashore to see him, and as a reward for having fed the people he was given an elk-skin blanket and a war club, and was set in the rich, soft soil near the river. There he stands to this day wrapped in his elk-skin blanket and holding aloft his war club.

I always think of this story as I pass skunk cabbage with its feet in the shallow water, its yellow spathe surrounded by rich dark leaves, and the whole reflected. in the shining darkness of the marsh water. Perhaps its unpleasant odor is a decided benefit because without it the skunk cabbages would make such fine house decorations that they might soon disappear.

There is one plant in the marsh which has personal significance for me, for the sight of its flowers reminds me of the few times in my life when my working minutes went like hours-the days when I hoed potatoes. The blossoms of this marsh plant resemble, except in color, those of the potatoes 
that my hoeing was supposed to stimulate into growth. It grows on the margins of the marsh and in many other places in the world. It was known to the early Romans and to the Greeks. Let me quote parts of Gerard's description in his seventeenth century Herball:

Of Bitter-sweet, or wooddy Nightshade.

Bitter-sweet bringeth forth wooddy stalks as doth the Vine, parted into many slender creeping branches, by which it climeth and taketh hold of hedges and shrubs next unto it. The barke of the oldest stalks are rough and whitish, of the colour of ashes, with the outward rind of a bright green colour, but the yonger branches are green as are the leaves: the wood brittle, having in it a spongie pith: it is clad with long leaves, smooth, sharp pointed, lesser than those of the Bindweed. At the lower part of the same leaves doth grow on either side one smal or lesser leafe like unto two eares. The floures be small, and somewhat clustered together, consisting of five little leaves apiece of a perfect blew colour, with a certain pricke or yellow pointal in the middle: which being past, there do come in place faire berries more long than round, at the first green, but very red when they be ripe; of a sweet taste at the first, but after very unpleasant, of a strong favor, growing together in clusters like burnished coral. The root is of a mean bignesse, and full of strings. ... .

The leaves come forth in the spring, the flours in July, the berries are ripe in August. ...

The decoction of the leaves is reported to remove the stoppings of the liver and gall, and to be drunke with good successe against the yellow jaundise.

The juice is good for those that have fallen from high places, and have been thereby bruised, or dry-beaten: for it is thought to dissolve the bloud congealed or cluttered any where in the intrals, and to heale the hurt places.

Tragus teacheth to make a decoction of wine, with the wood [of the plant] finely sliced and cut into smal pieces: which he reporteth to purge gently ... those that have the Dropsie or jaundice. ...

The plant is still used to some extent for rheumatism and skin diseases, and for poulticing abcesses or felons, which value is indicated by one of the early names for this plant, felonwort. No plant in our marsh is so persistent: I have recorded it as blooming in May and, soon after, I noticed 
blooms, young green berries, partly matured yellow ones, and the ripe coral-red berries all on the same plant, a condition which continues until at least the first of October.

Almost every journal of early explorers contains references to the gathering of vegetable. foods and speaks of seeing "a number of Indians" or of "meeting numerous natives," or of "men, women and children" all engaged in gathering, cutting, or digging some item of food. Ethnologists point out that the collection and preparation of food supplies usually was not a solitary affair but one in which large groups participated. Often it was an occasion for the summer meeting of friendly tribes, a meeting at which games, ceremonies, and gambling took place. Some of the more perishable fruits were eaten as they were collected, but it was the period of greatest food supply so that the collectors could eat their fill as well as set aside and prepare large surpluses for the winter shortage. The areas were gay with color, the natives happy and busy, and everybody, even the children, engaged in some sort of task.

The harvesting of the wapatoo was just such a communal occupation. Wapatoo is the edible root of a species of arrowhead, a perennial aquatic or marsh herb. The plant derives its name from the shape of its leaves, which resemble the head or point of an arrow. The leaves are coarse, heavily veined, of a handsome darkish-green, and of varying proportions, although all of them have the general arrowhead shape. They are found usually in shallow water. The underground stems are often several in number, each of which ends in an edible tuber. The flowers are white, showy, and are borne on long scapes or stalks, which makes them stand out distinctly. In the marsh they grow along the canal margins in fairly large numbers where the water is not too deep.

Gerard lists two species of this plant under the Latin designation of Sagittaria major and minor and under the English names of "water-Archer, or Great and Small Arrow- 
head." He refers these plants to Theophrastus and Pliny, but states that he finds nothing in writing concerning their virtues or temperament, a statement which appeared strange to' me, for the wapatoo, a relative, has been of the greatest importance in the economy of the Pacific Northwest Indians. They gathered it for their own needs, and used the surplus for trading purposes. Lewis and Clark, who described it in their journal, wrote that it was collected chiefly by the women who employed canoes from ten to fourteen feet long and light enough so that they could be carried easily. The women would take their canoes to a pond, where they would push them ahead and wade among the arrowhead plants. When they located the bulbous roots they would free them with their toes. When the roots floated to the surface they gathered and put them into their canoes. One can imagine the sight, the brown bodies of the harvesters outlined against the green of the swamp, the splashing, the comments, and growing heaps of the wapatoo in the cedar canoes.

On the shore near the marsh stood the small mat houses of the tribe, temporary shelters for use in such situations. Here the women, too old for work in the water, prepared the wapatoo for use. The little children played or, if too young, lay wide-eyed in their boards while the pits were dug and the bulbs roasted to make a product so highly esteemed that it was a regular article of commerce and trading. Surplus stocks of wapatoo brought many things to the tribes who prepared it. Buckskins and berries, horn and arrowheads, dried oysters and clams, and many other things which were plentiful in other sections were available to those who had wapatoo for trade. Lewis and Clark exchanged beads, small articles of copper and iron, and other trifles for it, and found the wapatoo superior to the camass which was so extensively dug by Indians in the less humid districts. Most of the early explorers mentioned the plant and its value to the natives. I could easily understand how the marshes in a country 
so heavily timbered as the Puget Sound region once was could have been looked to by the Indians for their food products. The forests stretched almost everywhere. Meadows, except in the higher reaches of the mountains, were not common. Little food of value grew in the dense timberland. It was the open park country, the few meadows, and the marshes which furnished the bulk of the native food requirements. When other food could not be secured the roots of the lady-fern and the bracken were cooked and served with salmon eggs and provided a palatable dish. Even the horsetail was eaten in emergencies. Some species of wild onion were esteemed and sought. The nettle, much used for food in Europe, does not appear to have been used as a food by our native tribes, although Dr. Gunther reports its uses as string for duck nets, as a rubbing material to keep seal hunters awake, and as a treatment for rheumatism.

Self-evident is the use of the berries of the marsh. The Indians ate them all: the cranberries from the bogs, the elderberries on the margins, the blackberries which hang over the banks in long hedges. I know how easily the blackberries are gathered, for many times in late August, with a leather glove on one hand to hold the canoe close to the prickly vines, I have picked quarts of plump and dust-free fruit-the most comfortable berry picking I have ever known.

There were few of the plants I investigated about the marsh which were not used by the Indians for some purpose: food, medicine, material, charms, or ceremony. A common shrub like spirea seems valueless but Dr. Gunther reports its use by the Quinault Indians who peel its smaller stems and make a string to hold clams for roasting. Perhaps that was the way the Indians had strung the dried clams which Captain Vancouver had noticed hanging on their persons like necklaces and from which, when hungry, they removed and ate as many as they desired. Edible necklaces, a device 
which, if adopted by modern jewelers, might help to carry their business over the dull periods of which they complain!

Here are uses for other plants obtainable in or near western Washington marshes: heated roots of yellow pond lilies applied to the seat of pain caused by rheumatism; Oregon grape for food, its root for a dye, its bark as an infusion to wash skin and mouth sores. The fruit of crab apples is well liked; its wood makes prongs for seal spears; the bark is boiled to make a brew to wash cuts and for internal use. Boiled dogwood bark cures sore eyes. Coltsfoot roots can be boiled to make a drink for tuberculosis patients or to use as an emetic. Yarrow was known to the Romans and Greeks as a curative herb and Dr. Gunther reports it of value to the natives of western Washington who sought it for a variety of uses: for a hair wash, for its aromatic qualities, for colds, stomach trouble, and as a general tonic.

Dr. Gunther believes that no portion of the United States furnished its native residents with a more varied, abundant, and well-balanced supply of food, without cultivation, than western Washington. The fact that most of the vegetable products were gathered by women gave them a better economic standing than that enjoyed by women in an economy where hunting was dominant.

Such uses of marsh products have almost disappeared. Modern society, accustomed to processing most of the primary products, appears to have discovered few outlets for all this growth. Marsh hay, packing material of reeds, cattails, and bracken, and a limited amount of dried material for life preservers constitute the bulk of modern requirements. It has become evident to me that if the marsh were to be appraised only in terms of removable crops it would have to be placed far down in the economic scale.

I could not quite understand this apparent waste. I could not reconcile it with the close utilization of resources which seems so usual in other communities. Ordinarily, production 
and consumption strike a balance so that there is little material left after the consumers of that material have finished with it. But, here, much was left apparently unused. I passed over the submerged plants of the bay. I could see minnows and now and then larger fish as they slowly swam through the lacery of the vegetation. The mallards and the coots fed in such areas but there was little evidence of disturbance or of any considerable use of the plants. I moved through the canals and inside channels: the knotweed in the coves stood knee-high and untouched by feeding animals. The muskrats had done so little damage to the cattails and bulrushes that it was not easy to see where they had been working.. Evidence of overfeeding was totally lacking. The whole marsh appeared lush and fresh. When the fall migrants arrived the $\mathrm{V}$ would find it as inviting as an irrigated meadow which had been saved for winter pasture.

It occurred to me that perhaps this need for winter food was partly the answer to the reason for this oversupply. When the hunting pressure in the marsh was so light that wild fowl lived and nested in numbers, there had been more use of these marsh facilities by the residents, and the proportion of consumption to production probably had been greater. But the marsh is now better equipped to carry out its role of wildlife hotel. Here the hard-pressed migrants will find food ready for them, as the food of a city hotel might be stored and ready for the rush of guests soon to begin.

I suspect that the indirect use of the marsh vegetation may be of more value than would be its direct use by man. The wildlife of the area receives its primary requirements of food and shelter from this vegetation. It enables the food chains to operate so that the life of the marsh may continue. The surplus is available to those visitors which so regularly take advantage of it. And perhaps it is not too much to say that the beauty of such untouched areas has a value which, though intangible, is considerable. 


\section{The Henpecked Shorebird That Goes to Sea}

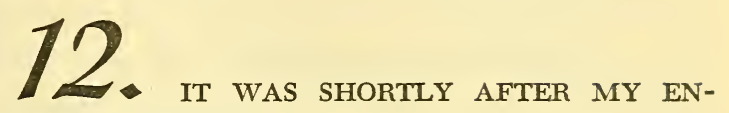

counter with the small catfish that I ran across an old bird friend in the marsh-the northern phalarope. The area was full of the hum of bees which busily occupied themselves in harvesting the climax honey crop of loosestrife. Since then I have always seen these birds under the same conditions in the area so that they, the bees, and the rich fields of purple bloom have been closely connected in my memory.

The sight of the phalarope recalled the first time I had seen it in the marsh. The canoehouse manager had hailed me as soon as I arrived at the float. He said:

"There's a queer bird swimming out there. It's lightcolored and floats high like a gull but it's too small for one. And it keeps whirling and pecking at the water while it moves. Looks like a shorebird, but if it is it's doing tricks that I never saw a shorebird do before."

"It's a phalarope," I said. "I often see them spinning like that at this time of year on salt water. I never saw one in the marsh before. We can add it to our records."

"You can label it 'new and goofy." It acts like a toy swung on a string." 
He had described the bird well. When I approached, it was whirling vigorously in a circle less than a yard in diameter and pecking at the rate of two or three times per revolution at bits of food that the disturbed water had brought to the surface. I remember my first impression: I thought this spinning creature had a trim fineness combined with sturdiness of the kind one sees in a distance runner. It had the general appearance of a tern but it was a small bird, smaller than a killdeer. Its bill was needle-sharp and about as long as its head, which moved back and forth, sometimes very rapidly, as the bird swam. Its general color was whitish but a grayish-dusky bar showed distinctly behind the eye. It did not call constantly in the manner of some of the shorebirds, but appeared much less boisterous and noisy. I placed it as a bird of quiet habits and one that would not venture over long distances, a surmise that subsequent information proved entirely wrong.

I stopped when a few yards away and watched the bird as it continued feeding. The long-billed dowitchers had allowed me to approach closely just as this bird did but their attitude was entirely different-a mixture of friendliness combined with wariness. They reminded me of robins as they reached for worms when I spaded in the garden. They did not object to my nearness, but merely kept a wary eye upon me to be sure that I was up to no tricks. But this bird simply ignored me. It did not look my way or change its course, and when it headed directly toward the canoe it made no effort to veer right or left but uttered an irritated protest at the obstruction. Even then it did not fly but continued pecking at food so close to the gunwale that I could have touched it without changing my position. Occasionally it flew a few feet, and, after stirring up the water with a couple of swings, fed again. Why it circled I did not know, for the surface was covered with small insects which seemed to make the disturbance of the water unnecessary. Back and forth it went. 


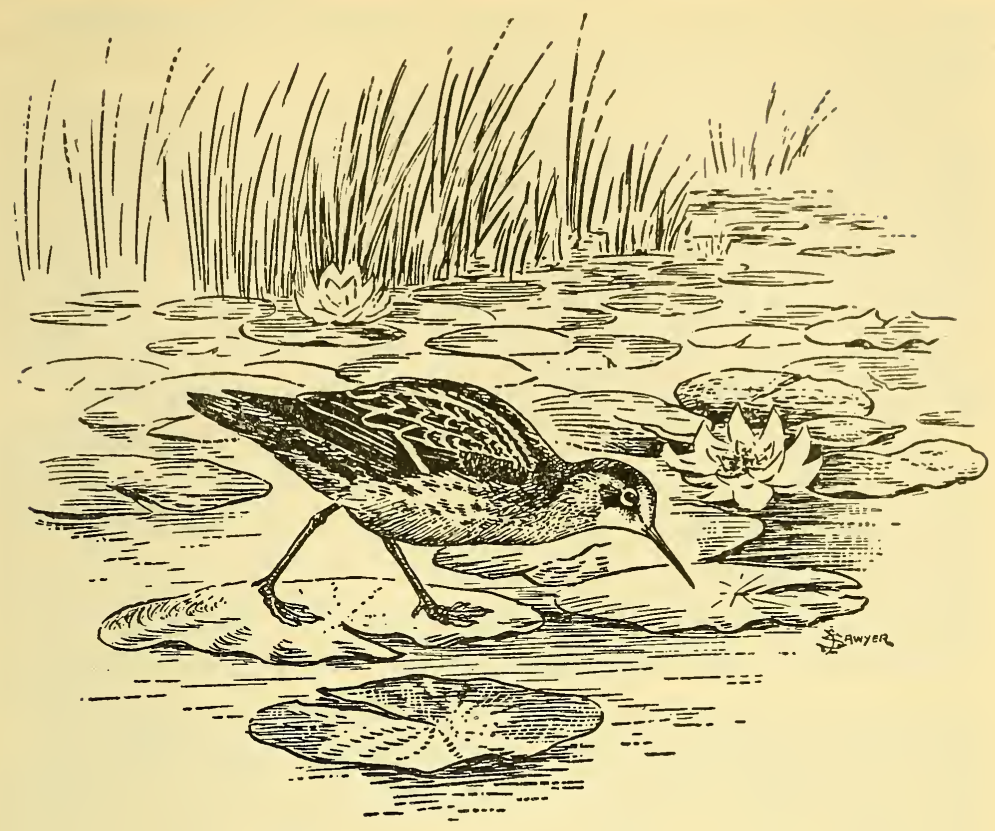

I followed slowly and carefully with the canoe. The unconcern that the bird showed for all traffic rules astonished me: its determination to follow any route it had selected seemed to indicate that it had met few obstructions in its early life.

The wind had dropped, the sun was about as hot as I had ever felt it in the marsh, and I had stripped down to shorts and a track shirt. Ordinarily the brightness of such days appeared to make the birds quite wary so that many of them, which never objected to my coming close on windy days, would fly when I was three or four canoe lengths away. But this shorebird which spent most of its time swimming, and which moved nervously, evidently had no fear of me or my moving boat. It continued its quick jabbing pecks, which at first had seemed rather aimless, but which I could now see were delivered with force and precison. Its prey must have been small on that day or surely it would have been forced 
to stop from lack of capacity, for it fed steadily while I ate my lunch and followed it about.

I wondered why it did not rest and bathe as was the custom with nearly all of the shorebirds which visited the marsh. I could think of no other shorebird which would allow so close approach and particularly on such a day; I had never before seen a bird with such peculiar mannerisms. I did not know until later that it possessed other habits which made the actions I had already observed seem commonplace.

This bird, the northern phalarope, is the commonest of three species of phalaropes which are found in the Pacific Northwest. The name phalarope comes from the Greek and means coot-footed, as their toes are lobed, like those of the mud hens or coots. They are shorebirds but they spend most of their time at sea. One of the others, the Wilson phalarope, is found in summer in the valleys east of the Cascade Range, while the red phalarope is an offshore bird and rarely comes to land except to breed or when storm driven. One great appearance of red phalaropes occurred some years ago and is still talked about, for these birds, never before noticed by the natives, were found in great numbers as far inland as Puget Sound. Scarcely a year passed after my first experience with a northern phalarope that I did not see one or more in the marsh. And often when I crossed Puget Sound on the ferry, dozens of them, plainly visible from the boat, would be indulging in their peculiar spinning system. A troop of Boy Scouts, in discussing the hunting methods of birds they had seen, placed the robins at the top because nearly everything they ate was easily obtained, but they put the phalaropes and the swallows in the lowest bracket, and after some deliberation they gave the booby prize to the phalaropes because they thought it took more effort for them to get their food by stirring up their "bathwater" than it did for the swallows to fly "about with their mouths open and scooping their food from the air." 
Nothing could have been better for my bird-watching purpose than this hot and quiet day, which made a vast mirror of the water and softened the views of the marsh with its haze so that it looked like a photograph which had been made with a diffusion lens. The bird showed no desire to leave and proceeded slowly through the open spaces which had not yet been clogged by the encroaching marsh plants. I could see no boats on the bay. Ordinarily half a dozen or more canoeists, noticing my binoculars and camera, would have paused to investigate and in all probability would have flushed my bird. I wondered where people were until I remembered that the paper of the night before had predicted a "perfect picnic day," which meant that they had taken longer trips and were at the beaches or the mountains-perhaps at Rainier which was plainly visible from base to summit.

I continued to watch the bird while it whirled occasionally, pecked, abruptly changed direction, and frequently went back over the same spot it had just left. It was a jittery appearing creature, although without the nervous habits of the killdeer which involved much running up and down, continual calling, and sudden flights. The phalarope lacked the teetering uneasiness of the spotted sandpiper which would not feed more than a minute in the same place, but it did have the aimless progress and apparent lack of direction of that bird. Judged by human standards it did not rate high, but as I learned more about the bird I found that it admirably performed the exceptional duties which made up an existence quite different from that of any bird I had met.

I did not know then just how different it was. I was beginning to realize that an observer of wildlife must assemble his information differently than a newspaper man. Had I been a city reporter interviewing a new arrival, I could have supplemented my observations by questions to bring out facts which would have told me the salient points of the man's 
career. But I could use no such methods with my northern phalarope. I could only make careful notes of the bird's actions and appearance when I saw it in the marsh, on the salt waters of Puget Sound, or in other places which it locally visited. If I wanted to learn more about it I had to talk to others or check the writings of those who had observed the bird at different times of the year and in various places and under diverse conditions. Its range was so great that it was not likely that I would see it on its breeding grounds or in its wintering areas. Probably few men who had watched it in its winter quarters would also have the opportunity to observe it nesting. It was quite certain that those who had studied the phalarope in the north or in the south would not see it in the marsh where I was sitting. In only one way could an approximately correct life history of such a bird be secured-by combining the observations of the observers in the north with those in the south, by adding all the notes describing the bird in migration, and by supplementing these records with the little particulars obtained by those who had the opportunity to observe the birds more or less intimately in their own local and restricted districts. Every detail had to be considered of importance in throwing further light on the bird's behavior. As an example, I offer this one.

Once I saw a northern phalarope on Lake Crescent, one of the most beautiful of our western mountain resort areas. It is not a likely feeding place, for the water abruptly deepens and there are not two acres of marsh on its entire margins. Timbered hills border its west side to a height of four thousand feet while to the east the imposing peak of Storm King thrusts brown rocky buttresses down into the green of the forest. The lake, long, curved, and narrow, is so blue that many a curious tourist has dipped a pail of water to see if it is really colored, only to find out that it is the blended reflection of rock, timber, and sky that has given the water its 
color. At the time of my visit the firs were shedding pollen which was drifting close to shore in a floating windrow of yellow. From my faltboat I spied a northern phalarope busily pecking among the bright grains. I watched closely and was quite certain that the bird was eating the yellow dust, and the more I looked the more certain I became until at last I began to examine the shining band with my binoculars. Then I found there were small brown insects on the water and that they, and not the grains, were being eaten. Had not the surface been absolutely smooth and my time unlimited I would have left with the thought that I had seen a phalarope eating pollen of the fir. Never have I read of another phalarope swimming on a mountain lake in such a sheet of golden yellow.

Because I had never seen a phalarope except when it was swimming, I was astonished to find some days later that a small bird which I saw running about the lily pads in the marsh was a northern phalarope. It paraded among the water lilies as if it were an avian mannequin. The faint blush of its light breast, the tawny stripes which broke up the darkness of its back, the small and typical phalarope stripe behind the eye, the sharp bill-all could be seen perfectly. Field glasses were only an annoyance because the bird often came within four feet as it fed over the pads in much the same way as the spotted sandpiper, which always sought the rich insect life present in August. Unlike the sandpiper it was careless or awkward so that it continually walked off the edge of the pad and into the water, from which it emerged with a flutter of wings and a sprinkling of drops, and then began feeding again. Because the pads were black with insects of several sizes, its intake was only limited by the speed of its attack. It went round and round on the fifteen-foot circle of pads, always oblivious of my presence, never still, intent on the satisfaction of an appetite which might have been due to the fact that it had just arrived at the marsh after a long flight. 
Once it started to fly away but some young barn swallows, which had been engaged in flight practice, dipped close enough to annoy or frighten it, so that it gave its protesting note and returned and started feeding again. I divided my time for the next half hour in watching another practice flight which was going on just to the south of the lily pads. A helicopter was making landings-it would descend noisily to within forty feet of the surface and there it would poise like a huge osprey and then drop lightly down to the water. Time after time I watched the maneuver and as I observed the precision control I thought that such flying was within the range of any person. But I did not then realize the skill required. Only a few days later the same training plane met with a failure of engine or pilot, and the occupant was killed at the very spot I had been watching.

At home in the ensuing weeks I began to read more about the northern phalaropes with the result that my attitude toward them changed considerably. I felt like a city reporter who had casually talked to unassuming and pleasant strangers at a reception only to find later that he had met an. Amelia Earhart, or a V. Stefansson. From then on the bird could never be just another visitor to be judged by the impression of the moment. It had now a fascinating and varied background which would repay constant and close inquiry. My small-town visitor had become a cosmopolite. The bird I saw in its plain grays and whites was not like the one which had doffed its traveling dress and attired itself for the breeding season. Then the female had worn gray-black plumage on the head, white side patches on the neck, and a nape of red, with its dark back streaked with brown, and with dark gray daubs running down from the upper sides into the light underparts. The male bird, contrary to the usual relationships of bird sexes, had been much more plainly adorned, but its spring plumage was brighter and neater and more attractive than in fall and winter. 
My reading and consultation with my Alaska friends told me why the male northern phalarope had been called "the henpecked shorebird which goes to sea." It does go to sea and probably for the greater part of its life. And the male is a henpecked bird with a role on the breeding ground which is somewhat depressing. He does not strut and pose as the leader of phalaropes nor does he have the delusions of grandeur carried by the cock in Rostand's play Chanticleer. It is the female that gets the top billing. She is larger, more dominating, much more elaborately attired, and does not hesitate to run the whole show. She gets into character from the time she puts feet on the ground which is to be her summer home. She does not wait for a suitor but, seemingly adopting the theory that what is worth having is worth going after, she starts out, makes overtures to the male of her choice, fights over him with her female rivals, chases him, browbeats him, makes seductively beautiful flights as he floats on the water beneath, and herds him constantly until she has won him and they are finally mated.

Is it any wonder that these visiting phalaropes had a different appeal to me after I had checked their records? My marsh observations would never have taught me the facts about them. I would have placed them under the head of queer or eccentric birds and would have let it go at that. The field of my marsh observations was narrowly limited. It had required the combined observations of many men over a period of many years to piece together the numerous records I had consulted. But with the information I acquired I could visualize the birds' departure from their offshore wintering areas, their speedy overwater flight to their far north breeding grounds, and their arrival on those foggy, bleak, and windswept beaches where snow patches still remained and ice formed every night on the ponds. The birds would gather, the courtship proceedings would begin, and the fighting females would quarrel with each other over the possession 
of the peaceful and somewhat indifferent males. Noise and activity would continue day after day, and into the night as well, until the courtship flights and the mating of the birds had taken place, and the bewildered males had found themselves under the sole domination of a larger and more determined bird.

It is certainly true that the harassed males do not realize the ignominy of this relationship; at least that is what the scientists would say. I am equally certain that most human males hope to the contrary. It may be that the male bird's intelligence considers that one act of appeasement will be sufficient. But it is not. As in all appeasement, the preliminary yielding is not accepted gracefully, but merely sets the pattern for further demands. The female may select the nesting site and lay the cornerstone, so to speak, but the male soon finds himself collecting the grasses and other material for the scanty nest which will be no credit to the sex of the builder. The laying of the eggs may give the male false hopes, but they are soon dispelled when he finds himself charged with the duty of brooding the eggs, while the female makes a great show of vigilant patroling of the area and between times foregathers with others of her sex.

I would like to report that brooding ends the duties of these unfortunate males, but after the eggs are pipped and the young are off the nest one of the pair takes on the greater part of their care. It is not the female. Management is her forte and management is practically all she contributes. The poor sire, the beauty of his plumage marred by the tell-tale brooding patches, probably looks out each morning at the sun, which rises very early on these northern breeding grounds, heaves the equivalent of an avian sigh, and starts to herd the three or four young which are already peeping loudly for food. What a spectacle for the males of other species to watch! What a sermon against the overindulgence 
of mates! What disgust must be aroused by a review of the summer schedule of these males!

It cannot be an easy task to raise these active precocial mites, which can swim on the first day of their life and can run nimbly about clad in their rich buff upper down and silver gray underparts. The males act, I suppose, much like the females of other species, and call, scratch, probe, and peck, and indicate by example just how a mature and capable phalarope proceeds in the business of getting a living. The three or four chicks may all live, they may be all wiped out, or perhaps one or two may be secured by a persistent skua or jaeger, or by some wily mammal.

If I have treated the family activities of the phalaropes in a rather unscientific vein, it is not because I fail to realize the mental limitations of birds and their inability to reason and think. I have taken this course because the situation is so unusual and amusing as to be worth presenting in that way. Perhaps it is well to remark that many questions concerning this apparent reversal of family duties remain unanswered. How common is the practice among other species? What suggestions have been made to explain its origin? Mating ardor of male birds is usually regarded as exceeding that of the females, which normally perform the greater part of the duties of nest building and the brooding and care of the young. Can it be that the assuming of this work by the male leads to the mating aggressiveness of the female?

The early arrival of phalaropes has greatly puzzled me. Two of them were obviously young birds. The nesting records in the Yukon region appear to indicate that no young appear before the third week in June. Could one of these birds acquire its flying plumage, make the long trip south, and appear in early August? Or is it possible that the breeding range extends farther south than is usually thought? It has been stated that the Indians of the Pacific Coast claimed that the bird nested along the coast of British Columbia but 
I have found no confirmation. The early record of a young bird in our marsh might possibly indicate the existence of a nearer and earlier breeding ground. At any rate it demonstrates the vexing exceptions that disturb what are thought to be well-established patterns.

The phalaropes justify their name of sea snipe or swimming plovers, for when they are not on the breeding grounds they live largely at sea. They have been seen on the coast of Africa, offshore along Peru and Chile, near Borneo and New Guinea, as far south as Patagonia, and are reported to winter as far north as southern California. Which of these places would the bird on the lily pads visit after it left the marsh? If it flew the offshore route along the coast it may have stopped south of Los Angeles or along South America where Robert C. Murphy, in his book Oceanic Birds of South America, reported northern phalaropes

... in vast numbers along the whole length of Peru ... large flocks in Pisco Bay ... thousands in oily looking patches on the water along the coast to southward of San Lorenzo Island . . . thousands upon thousands flushed by the southbound steamer near Mazorca Island. . . .

Regardless of where the bird wintered it is quite probable that its flight would be one of several thousand miles.

The phalaropes which left the marsh would not be free from the danger which has always attended migration. Such passages over land have produced countless tragedies with losses running into hundreds of thousands of birdś. Migration over water is more hazardous, for there are few or no landing places, no protection from sleet or snow which often accompany gales. The birds must fly on and if exhausted can only drop helplessly into a caldron in which even strong-swimming species cannot live. Other hazards await these travelers. William Brewster, the ornithologist, found in one place that:

Most of the birds [phalaropes] examined had lost one or more toes, and two or three an entire foot and part of the tarsus also, while others 
showed gaping wounds on the breast. These mutilations were probably caused by the bites of fishes.

I have often recalled the visit of the phalarope and of the manner in which it abruptly ceased its feeding and disappeared over the south rim of the marsh. Was its passage a safe one? What area did it ultimately reach? The words "not a sparrow falls" seem particularly applicable, for if any creature appeared in need of protection it was this small bird as it headed for hundreds of miles of open ocean.

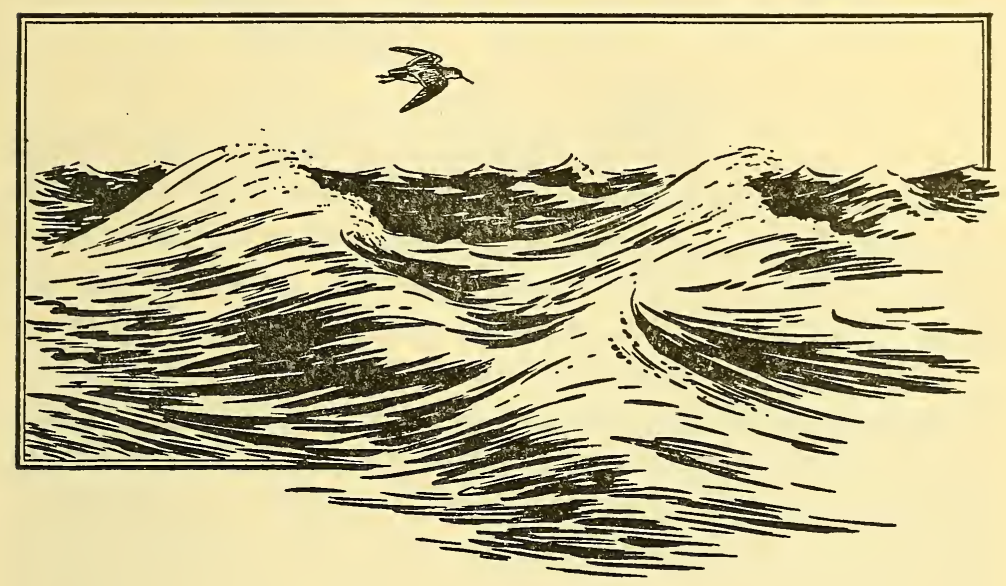




\section{Among the Guests Registered}

\section{3.}

I SUSPECT THAT THERE IS A TRACE of the collector in most of us so that we like to gather things or materials or sensations. Even those who are content to go along in their ordinary routine gleefully welcome the unusual, whether it be in pottery, golf scores, boat races, or anything else in which they have an interest.

I have always assumed such an attitude toward my experiences in the marsh-a more or less philosophical and placid acceptance of the ordinary and a keen delight in every deviation from it. On many occasions I have seen nothing of consequence during the whole day, the sum total being only a few additions to the little I had accumulated about this or that bird or mammal, a few more notes on the vegetation, the effects of the changing water depth, the unusual variation in the shape of the arrowhead leaves, or any of a hundred other trifles. On one occasion I watched a fight between two coots, an affair which came close to being a burlesque duel, a contest in which two clumsy birds raised themselves into an upright position, which they maintained with their wings while they sparred mightily but without causing any visible damage. One of them, either from loss of energy or 


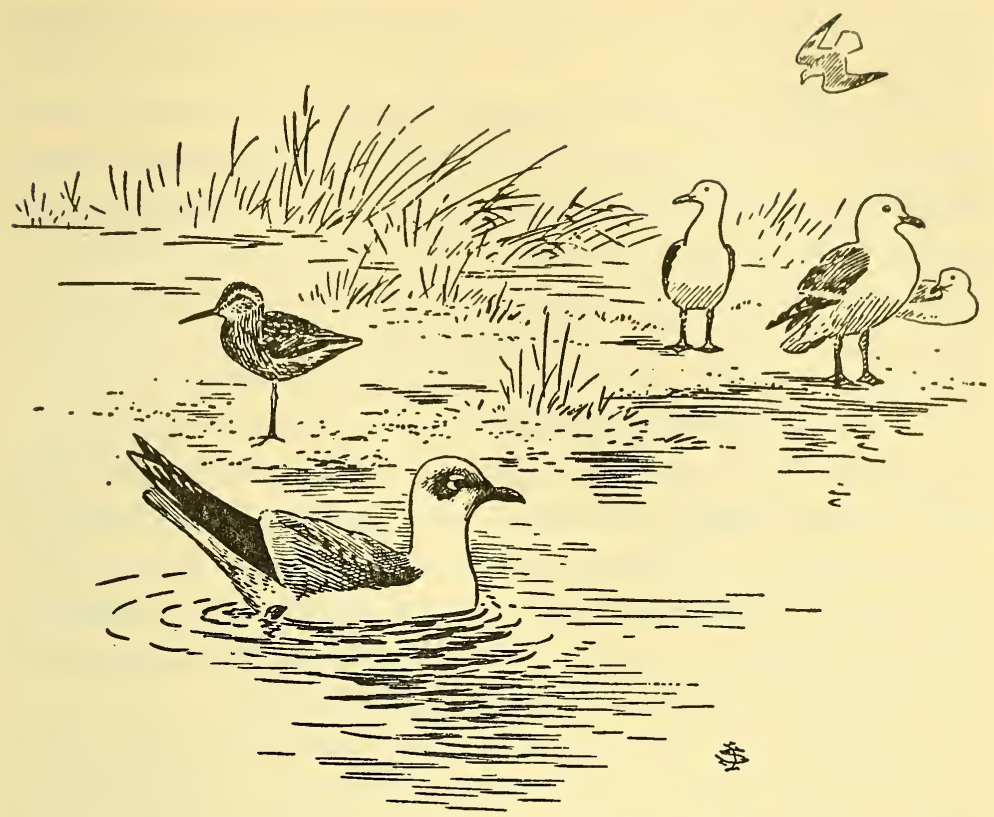

without enough confidence in its cause, eventually found the going too tough and dived to end the battle. The victor uttered what was apparently meant to be a song of triumph and poised to slam the diver when it reappeared. Its emergence was only momentary for the blow it received was sharp enough to send it below again, bereft of valor and convinced that other spots in the marsh were more healthy. When it reappeared it was several yards from the winner. Another example of the comparatively trivial was the posing of the white-crested cormorants, black-colored snaky-necked birds, which used to perch on a pile and then stand there for an hour or more with wings outstretched. At first I thought it might be part of a courtship performance, but it is not confined to the breeding season. Nor can it be done only to aid wing drying, for I have seen them with wings widespread in the rain. They looked silly, whatever their purpose, and any 
stranger who observes the performance invariably comments on it.

This is the type of routine that goes on in the marsh, the kind of news which, if it concerns people instead of swamp birds, finds a place in the local column of the neighborhood paper. Such news gathering in the city requires much leg work and at times becomes most boring. It is a large part of a reporter's job, but each of them knows, as my marsh experience had taught me, that behind all of this routine lies another field full of glamour and excitement. It is the prospect of getting into that field that keeps a reporter on the job, and it often brings him back after he thinks he has quit permanently. Constantly, like the prospector following his burro over the hills, he can keep up his interest by thinking that this might be the day-the time when the unexpected could happen and furnish him a famous story.

The marsh can be compared with the city, my visits with a reporter's. There are the usual incidents involving the regular residents and frequent visitors, the common events such as the two examples. And then in the background is the other field of the more infrequent but infinitely more dramatic and impressive. This principally concerns the arrival, the stay, and the departure of the important and irregular visitors, those guests with reputations as international travelers. Then, too, we occasionally see creatures with curious habits, striking characteristics, and birds which are common on the seacoast or beyond the mountains but almost unknown in our area. The sight of these strangers stimulates the marsh observer just as the sight of some rare book excites a collector, and the opportunity to see them is always a great privilege. These are the types of incidents that I have in mind:

East of the Cascade Range and not much more than a hundred miles away lives the loveliest of all North American blackbirds, the yellow-headed. To look at one is to see gold 
and ebony made more contrasting by white on the wingsflashing brilliance in a sunlit valley, legs clinging to rushes, head erect while the bird sings, a perfect subject for an artist. It occupies the reedy areas of ponds caused by irrigation overflow, or the shallow margins of potholes-any place where enough water stands to create a rush and cattail situation. Little can be said of its song for, although it has plenty of volume, it is coarse, harsh, and unmusical. If one is to hold the mood evoked by the bird's beauty, the song must be ignored and attention concentrated on its plumage and surroundings. When I drive through marshy areas in eastern Washington I often see yellow-headed blackbirds, hear their chatter, and watch their incessant activity.

I had never seen the bird west of the Cascade Range until a friend and I flushed it in the soggy brownness of a showery day in the marsh-a bit of beauty minus the setting of the valleys and plains in which it was usually found. Redwings were all about, song sparrows and tule wrens sang, for it was the breeding season and life was pleasant. Even the gloomy bittern betrayed by its call that it had taken, or awaited, a mate. It was just after six but many automobiles hurried on their way to work.

The bird stood on a log that had stranded a few yards out in the bay. It was silent and motionless as if aware of the strangeness of its surroundings. It remained only a few minutes but that was all we needed to identify it, for no other bird in the Pacific Northwest wore that combination of black and yellow. When it rose it gave a slight call and, splendid in the morning sun, started toward the north. With its departure came a slight irritation due to the questions that the presence of a strange bird always caused. What brought it out of its usual territory? It could not be ascribed to any habits of fall roving, for the bird obviously was on its way to the nesting grounds. Was it merely wandering from regular routes as people do? If so, why didn't more birds like it come 
into our area? Was its roaming in any way connected with storms, or with some failure in the bird's directional mechanism? Would a bird which started to wander continue the next year and during the remainder of its life? Someday I hope to meet a person who can give me the answers.

Other birds from the east side of the Cascades eventually added their name to our register. The black-crowned night heron, a sturdy edition of the herons, is chicken-size, rather long legged, and mostly gray in color. It is fairly common around eastern Washington marshes, but is so rare on Puget Sound that its name has only recently appeared on the local check lists, and I have seen it but twice in our area. The day of the first visit was not particularly appropriate, for sunshine and a football game had brought a capacity crowd to the stadium and their cars were parked right to the banks of Canoehouse Bay. I saw the heron on an old float less than half a block away from all the din and confusion of the parking. It stood motionless, apparently tired from a long flight, and regarded my close approach with indifference. A green heron, equally apathetic, stood close by it. The black-crowned was not a new bird to me. I had seen its yellow legs, white forehead, black crown and bill, and dumpy body many times before. I had observed it in eastern Washington, in the Middle West, and in the East had watched its after-sunset flights from the nesting grounds to its feeding areas along the low banks of a stream or in marshy ponds. But I had never before come within two canoe lengths of one. It did not move a foot from the place where it first stood. I have seen other newcomers almost as quiet, and I have often wondered if the complete inaction and lack of fear is due to fatigue or whether there is a more likely explanation. I left and made a trip around the marsh only to find it in the same place when I returned. I could not find it two days later.

Another type of visitor which has been on our marsh register only one time is the buff-breasted sandpiper, a rare 
bird which once was present in large numbers in the central part of the United States. It has two habits which practically insure the destruction of any shorebird-the first is its lack of fear of the hunter, and the second, its habit of flying in compact groups. This eight-inch shorebird has never been plentiful in the Pacific Northwest, but now it is so rare that I had never before seen a live one and knew it only through specimens I had studied in the museums. Few birds are as easy to identify. The way in which it stretched its neck reminded me of a pectoral sandpiper, although it was entirely different in other respects. I made the usual notes for use in checking and recorded the short bill, yellowish legs, feathers of back with blackish centers, but the recording was only to follow the established routine for I knew the creature the minute I saw it. No other shorebird visiting our region had the uniformly tan underparts displayed by this species. This tan almost matched the sand upon which the sandpiper walked so that I faced the task of photographing a bird against a background of almost the same color, an extremely difficult job. The result proved valuable for identification but almost worthless as a photograph.

I learned many things by observation during the time it remained in the marsh. I tried to follow it with the canoe as it fed on the small island, but it always kept far enough ahead of me to make that effort useless. Then I found that the bird followed a route regular enough eventually to bring it to me if I stayed quietly in the grounded canoe. It fed quickly and intensively in one spot before flying a few yards to repeat the process. It was constantly among the gulls on the flat, and when one of them would make a move to peck it the shorebird would jump a foot or two without apparent alarm and resume feeding. It stayed aloof from the killdeers that moved about.

In the evenings I read many interesting things about the buff-breasted sandpiper. Although I had long since ceased to 
be astonished at the distances traveled by some small birds, I was a bit overwhelmed to know that W. H. Hudson, the English naturalist who had written of the La Plata River region in the Argentine, had noted the annual southward passage of the bird to Patagonia in October. He maintained that many thousands of the birds wintered there. He had observed them flying north in April and May. So far as I could ascertain, the only breeding site is on the northwest coast of Alaska. Even if many of the birds do not winter as far south as Patagonia, the distances traveled by all of them are tremendous and their schedule exceedingly close. There have been many explanations of the causes which impel a bird to winter nearly two continents away from its nesting area but none that logically accounts for this trip.

I continued to watch the bird until the eighth day when I found it had disappeared. It had been a brief stop, but when I calculated the distance it must travel before reaching its winter grounds, I concluded that its stay was long enough to be a real tribute to the marsh and its hospitality. As the thrillers would say: "Here is a bird that ventures everything for love. It annually makes a trip of from twelve to sixteen thousand miles in return for three months of family life."

While I had been busy watching this tan bird move about on a similarly colored background, I nearly allowed another important record to pass unnoticed. Such activity in this small marsh hotel was without precedent. One real interview at a time, with a considerable time between interviews, was all that I had been trained to expect, but now I was in the exciting position of a small town reporter who, while calling on a general on a visit to friends in the locality, had received a telegram announcing the arrival of the governor on the afternoon train. Luckily I did not have to divide my time between two sections of the marsh, for this new notable had been an occupant of the same flat where I was watching the buff-breasted sandpiper. I had casually noted this gull for 
two reasons: one was that the other gulls, which it passed by, or which approached it, resented its presence and invariably made one or more vicious jabs at it, as barnyard chickens might peck at a strange hen. The other reason was that, when it faced me, it showed a black area on either side of the head which vaguely resembled the sideburns of a duck hawk -markings which I had never seen before and which I first concluded must be a transition stage in the plumage of a local gull. But on the second day, when the noise of a speedboat sent every bird on the island into noisy flight, the dark wing tips and white along the wings satisfied me that I was looking at a bird which to me was entirely new.

I did not rush my search. I did not find it easy to observe the bird even though I had plenty of time. The small triangular-shaped island had a tiny low spot in its center which the stranger insisted on occupying and which it left only when other gulls crowded it out. I was on vacation. The marsh lay under a warm September sun; the air was comfortable so that a shirt was unnecessary except as a protection against sunburn. I could hear yellow-legs and Wilson snipes calling, and frequently they passed so close that I caught the sound of the wind in their wings. Often the least sandpipers and other small peeps landed near and fed in rather close formation. There was much to see and little reason to leave. My notes on the bird were fragmentary and read something like this: "acts like a large tern, floats high with tail held more erect than other gulls present, pearl-gray mantle, white marking around all but front of eye, white edging on rear of wing, legs dark. ..." With the aid of these and many other notes I learned that the bird was a Franklin gull, once called Franklin's Rosy Gull, and popularly known as the prairie pigeon or prairie dove, a bird which had been recorded as a Pacific Northwest visitor not more than two or three times, and had never been reported in King County or in our city marsh. The colored movies proved sufficiently detailed to 
substantiate the sight record, and the taking, a few miles south, of two specimens by a collector was additional confirmation.

I was greatly interested, while checking the records, in noting the attitude which many of the conservative ornithologists took toward the matter of range. It has always seemed to me, and I think my view is substantiated by my observations, that range is often too flexible a thing to be outlined by sections, counties, townships, or even states, and that no man is in possession of enough facts to make the statement that "the range of this bird is as follows," and then proceed to outline it exactly. I submit that every statement of territory needs qualifying by some such phrase as "present information and records indicate a range as follows." In the case of the Franklin gull, nearly every authority from the time of the great Elliott Coues outlined a range which has been progressively enlarged by succeeding writers who, in turn, have had their arbitrary limits set aside by additional information, so that when we come to the South American marine bird authority, Robert C. Murphy, we find that he has seen countless numbers of Franklin gulls off the shore of the desert portions of Pacific South America-a prairie plough-follower wintering in southern oceanic waters.

I felt well repaid for my examination of the information regarding the Franklin gull. I found that it is a highly respected and welcome bird in the great wheat districts where it follows the plough in huge flocks and sweeps down upon the wealth of insect life upturned by the ploughing. It builds colonies of nests in the marshes and at the edges of the prairie lakes, using the reeds for a foundation and strengthening them against the normal winds and waves. It flies about the plains and takes many grasshoppers on the winga habit which is largely responsible for the esteem in which the bird is held. Its home is normally on the prairies east of the Rocky Mountains and reaches north into the wheat- 
raising area of Canada. Few birds are seen on the eastern seashore. Just what brought this gentle stranger to our marsh is, of course, something I cannot answer. I would like to know where it went from here and if ultimately it joined its kind on the desert coast of South America.

Another bird which visits the marsh infrequently brings a feeling of regret along with the interest it arouses. I refer to the large bird with whitish head and white underparts, the osprey or fish hawk, once a regular resident, then a frequent visitor, and later driven from the scene by advancing civilization and the direct action of man. One of our early ornithologists told me the story of a pair of ospreys which formerly nested on an island in Union Bay for at least twelve years. There they raised their young and took the fish necessary for their existence. The number of fishermen increased with the rapid growth of the city and, as is always true in such situations, the waters no longer yielded in their former abundance. My friend said that the failure of the trout supply was ascribed to every cause except the logical ones-the great increase in the number of fishermen and the practical lack of control of the size of their take. Among the agents blamed for the lack of supply were the ospreys, and this in spite of the fact that there was only one pair in the vicinity. But an osprey lives on fish and though trout, being a hard fish to take, probably were only a small part of their diet, it was decided that the birds should be eliminated. One day, some public-minded citizen, probably quite sincere in his belief that he was doing a service to humanity by denying this one pair of birds their right to existence, "shot up the nest," and destroyed the two birds. My old friend, the ornithologist, who was also an expert fisherman, remarked that there was no noticeable increase in the supply of fish: the only effect of the shooting was that this splendid white-headed air master, with its flashing light underparts, was never again seen swooping down into its home on the island. 
There are still some ospreys left in the state, and when I have flatboated on the Snoqualmie, the Stillaguamish, or the Yakima rivers, I have often heard a cry overhead and have looked up to see one or two of these birds as they followed the bends of the river in search of sustenance. Only once have I seen an osprey feeding in the marsh; at that time it took a fair-sized catfish from shallow water and ate it while I approached with my camera and managed to photograph it. The reappearance of the bird has become an event of greater significance as time passes, for since this incident five years ago I have not observed the bird over the marsh.

I have the records of other famous casual and irregular visitors: the bald eagles which have never nested in the area but which pass infrequently while on migration; the blackbellied plover, the small shorebird for which I have always had a tender regard. It has only to raise its wings and it shows a black patch which instantly identifies it. There was the red-throated loon, a handsome migrant which died almost in front of the canoehouse after a thoughtless lad had shot it with a .22 rifle. The only consolation is that its skin is now in the museum on the campus. The whistling swans which have appeared about every other year have given local observers a fine chance to see them for they have allowed remarkably close approach.

The birds mentioned in this chapter are neither regular nor frequent in their visits. I have seen but one or two from this class in an entire year, but I have been content to watch the normal How of life in this marsh, to witness what would be called ordinary routine in city life, and to know that, sooner or later, the canoe would flush a strange bird and send me to the records in an effort to learn its name, its history, its habits, and the places from which it had come and to which it was going. 


\section{A Firm Seat}

\section{4.}

A FRIEND OF MINE WHO LEANS much more to under- than to over-exercise, and who impresses me as being rather proud of his inactivity, once said that there were two places where a man needed a firm seat. One was in riding a horse and the other was when taking a restful vacation. Evidently he had been investigating hobbies for he said to me:

"What about these marsh trips of yours?"

"What do you mean?"

"You talk a lot of paddling here and there. You sound as if you are always on the move. Don't you ever stop and rest?" he asked.

"Certainly I do, and often."

"What happens then?" he inquired. "You see nothing until you start moving again?"

"You see plenty if you keep your eyes open."

"And if you don't keep them open?"

"You get a better nap than you do at home, and with plenty of cushions and nothing to disturb you. But your nap will be short," I said.

"Why?"

"There's too much to look at." 


\section{"Honestly?"}

"Sure enough," I said. "I'll tell you what I'll do. I go over there once, or more, each week. The next time I'll stay in one place and make a record of what goes on and what I think of it. Then you can look over the notes."

"Good," he said. "That option of a nap with every canoe trip sort of appeals to me."

It was just twelve when I arrived in Gadwall Cove. The University chimes struck with a clearness which indicated a fresh northwest wind. The inlet, equal in area to about two city blocks, could be reached by narrow entries both. of which permitted a limited view of Union Bay. I beached the canoe at the edge of the bulrushes so that I could look all about the cove, into the bay and ship canal. Cattails surrounded the area and in a few places made little clumps of vegetation in the center. It had been cloudy in the morning and the patches of water lilies had no open blossoms, but within half an hour after my arrival the sun had changed their tight greenness into a mass of white and yellow.

I adjusted the pillows about me, got out my notebook and leisurely ate the cheese. sandwiches, milk, chocolate, and cookies which I had brought. I had begun work at six so that I could get away early. To loaf now was pleasant. My dark glasses brought the sky into more brilliant contrast and made the clouds brighter and the sky a darker blue. Bird songs were missing, nesting season was over, the rissetbacked thrush had stopped uttering its sharp whirt from the bushes. But I heard many other sounds. The bees hummed as they moved about in the blooms. Some goldfinches called as they passed. It was time to begin my notes.

Tuesday, August 4, Union Bay marsh.

Weather, sunny-cloudy; wind, northwest, warm. Time, one P.M. 


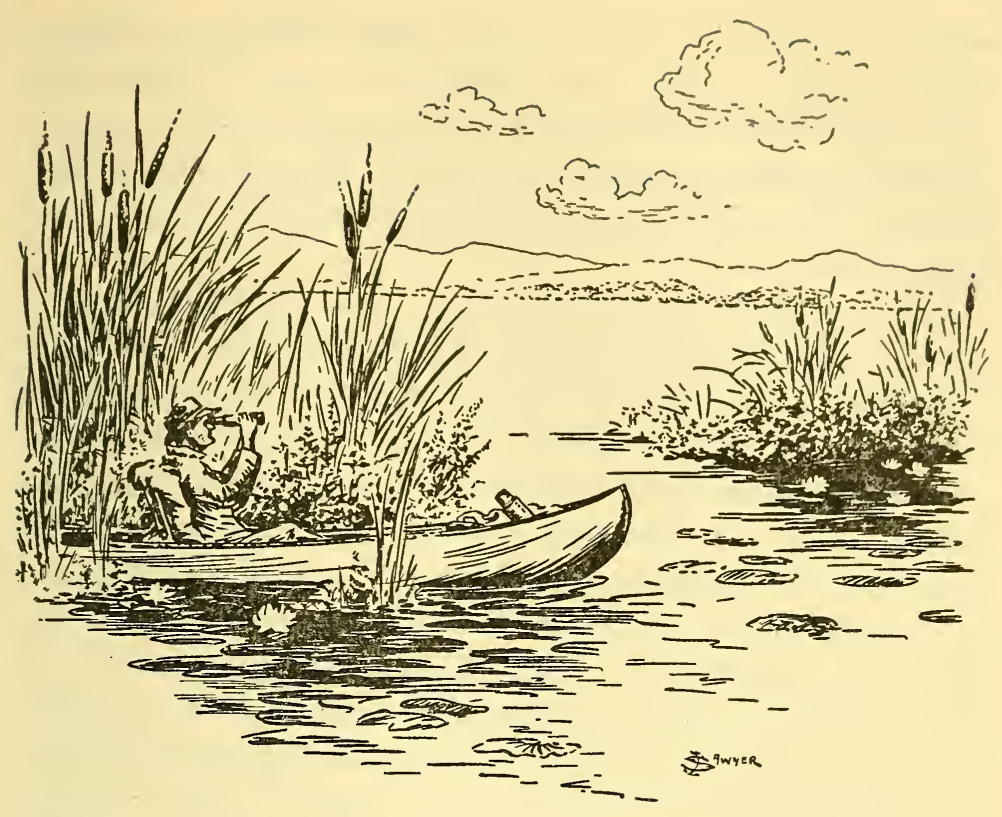

My canoe is now in Gadwall Cove, grounded so that the view on three sides is nearly unobstructed. I have just finished my lunch. Loosestrife blooms hang almost directly over me and their long purple heads are constantly visited by bees. Big blue flies occasionally approach the canoe and add their buzzing to that of the honey hunters. The wind sweeps the cattails back and forth so that they make a light and pleasing sound as they touch. Now and then I hear a noise which makes me think somebody is near, and I look about to see if the voices come from a boat. I understand why people lost in the woods become confused and think they hear voices because I often note such resemblances when I am out. The streams in the mountains, the whistles or calls of some of the birds, the calling of frogs, and even such small things as the noise of insects frequently resemble the talking or walking of a man. I hear now a sound just behind me that 
simulates the even step of a light foot walking on autumn leaves. There is no person behind me, and I do not know what the cause can be until I turn around and find that the projecting canoe paddle is being struck by the regular swaying of a wind-blown cattail leaf which is just dry enough to make the sound.

The cove is a comfortable place. The mixture of various sounds becomes quite soothing. I pull my old tan hat closely down and fail to regard the scene with the attention required for first-class observation. My thoughts turn to Billy, the older of the two dogs belonging to the canoehouse manager. When I took out the canoe the dog had just-been brought back from a veterinary who had removed a head of foxtail grass which had worked into the animal's ear. The dog had been given gas and he looked thoroughly done in. I had always considered the relationship between this man and his two dogs an ideal one. There was never any monkey business or domination or sentimentality. It was an actual working partnership with mutual obligation and respect. Today they had sat on the bench together. The man said nothing but petted the dog occasionally as it nuzzled close to him. I thought it was a most agreeable sight.

A boat whistling for the bridge awakes me, or possibly it is the noise of the bees which pass within a foot of my head. I watch them take nectar. My drowsiness vanishes. Each bee goes methodically up or down the long spike, working on all sides of it, and then, as if satisfied that its possibilities are exhausted, moves on to another head. I consider this apparent draining of the flowers on each head quite efficient, until I notice that when one bee leaves another soon takes its place. Whether the first one fails to extract all the nectar from the flower or whether the new bee visits only the flowers overlooked by the first is more than I am prepared to say, but I observe that the procedure is followed time after time. 
Two damsel flies land on the masses of tiny duckweed plants floating near the boat. At first I do not know whether they are feeding or resting. The fact that they make short moves from one part of the mat to another seems to indicate the former. The male is quite gay with blue marks on the head and at the end of the abdomen. The female can easily be distinguished by its plain straw color. Then they fly to a lily pad and I watch the female reach under the edge of the leaf with its abdomen curved, evidently for the purpose of depositing eggs. A bursting bubble of marsh gas agitates the water and sends them into quick flight, but they do not fly far and I watch them repeat the process.

The marsh is no exception to the rule that most communities have their distinctive sounds, so that by listening to the combination it is possible to place not only the area but the season as well. This marsh, with its mixture of natural and man-made sounds, is especially distinctive. Such things as the roar of planes warming up at the Sand Point Naval Air Station, the call of the coxswain as he raps with his blocks to set the pace for a University shell, the hourly blast of the ferry whistle-all help to identify the location. When manmade sounds are combined with bird songs and cries and the splashes of the mammals, any sound detective (if there is such a specialist in the sleuthing profession) could easily make a positive identification. Today there is no activity in the stadium, on the practice field, or in the shells, but loud sounds of bridge siren and bells, the horn of the ferryboat, the planes at Sand Point, and the campus chimes contribute all necessary information for placement. The total absence of general bird song, together with the cry of a yellow-legs which never appears until early in August, and the loudspeaker of the summer excursion boat which operates between Lake Washington and Puget Sound, places the season of the year as summer and the month as August.

I pull out a strand of water smartweed which projects 
from the surface of the water at the rear of the canoe. It is a valuable plant because the waterfowl esteem it highly both for food and for cover. It is a near relative of the plant called lady's-thumb, a troublesome and widely. distributed weed which derives its name from the fact that the leaves are generally marked with a dark blotch as if they had been bruised by pressure. Several legends are connected with this plant. One concerns its attempted use. as a poultice by Mary, who pinched the leaves when she found them useless as a cure for the injured hand of Joseph. I have always thought that only lady's-thumb, one variety of the smartweeds, carried these blotches, but many of the leaves of the plant in my hands bear the same mark as its land relative. This water plant will soon be covered with a small and inconspicuous bloom of a pinkish cast and borne scantily on a raceme, quite different from the rather solid heads of the shore variety.

I look about the cove, formerly a purple circle of loosestrife and so shallow that I could not force the canoe through it. Now that the water depth has increased, the loosestrife remains only in the shallower portions, and the center has been abandoned to the carp which come annually in numbers to spawn. The cove is muddy then, but now it is quiet and the water clear.

The wind increases in strength and the overmature petals of the loosestrife are blown into the water in quantities great enough to make floating patches of color. The University chimes ring. As if waiting for the sound, several mallards start bathing and a pied-billed grebe gives its barking call. I wonder if the call is an indication of a second brood or whether it is just a leftover from the first. The mallards bathe noisily like a group of boys; they force the water through their plumage and then begin to shake themselves vigorously. This should make a good slogan for children: "If the water birds bathe regularly, why can't you?" The clouds over the Cascade Range have formed a wall which shuts off the view. 
The wind keeps the cottonwoods on the nearby island moving briskly enough so that their rustling can be heard plainly.

Two paddlers go by in a white canoe bearing the name Cupid. They are husky lads, stripped to the waist, with a good stroke, and lots of power in their well-developed shoulders. As they say about promising young politicians, they will go far. They are headed for the lake and it may be that the gunwales conceal a camping outfit. Flatties begin to come: some trying to get out under their own sails, others towed in a string by a powerboat, all in a hurry to join the many others which seem to put out from nowhere the very instant that a good breeze comes up.

The discordant clatter of a kingfisher attracts my attention as it hovers over one of the entrances to the cove. I count to twenty-one at second intervals before it ceases hovering and dives into the water below. A clump of cattails obscures the splash so that I do not see the attack, but as the bird flies away it carries nothing. A second bird joins it and they dash at each other in mock combat, rising higher and higher, and making harsh noises. Finally they level off and fly away.

Bees. Do they live in the marsh? If not, where do they come from? I see few except when the big honey crop is being harvested. How does this enormous aggregation keep busy at other times during the season? How far do bees ordinarily forage? I must try to find out. Are these all wild bees or are there a few hives left of the many that used to be seen around the north end of the district? I see one bee struggling in the water. It is near a plant stalk but seems unable to gain a foothold. I pull it out and place it on a blanket in the canoe where it dries in the wind and sun and then flies away. I suppose that the flycatchers and the swallows take many of them, and those which fall are soon picked up by fish.

The damsel flies come around again because they like the warm and comparatively windless corner where the canoe is 
beached. Then a dragonfly rests on a projecting branch. The insects are both of the same general color pattern, a pleasing light and vivid blue, similar to that so often used on the shutters of modern cottages. Both are banded with black but are not close enough so that I can compare color pattern. The difference between these two insects superficially reminds me of the difference between the swifts and the swallows. In each case there is the same general method of gaining a living, but there is also a great difference in their range and speed. The swift is among the fastest of the birds and has a feeding range probably much in excess of one hundred miles a day. The swallows are less active and operate in a much smaller territory. It is so with the damsel flies and the dragonflies. Both are predatory in their habits, in their nymph, or premature, stages when they live under water, and when, in maturity, they fly about the marsh. The dragonfly has a speed and darting habit which reminds one of a hummingbird. The damsel fly is slower, more indecisive in its manner of flight. The insects which have been perching near me leave almost at the same time, the damsel flies to alight a short distance away, and the dragonfly to disappear over the tops of the cattails. The nymphs of both varieties are probably in the tangle underneath the canoe, lurking in places where they can seize unlucky victims which may come within range.

The additional warmth of the afternoon, or the fresh breeze, seems to stimulate activity among the birds. Cliff swallows make their squeaking flight sounds as they constantly fly overhead and hawk for insects. I can remember when there were few of them around the marsh but now they are plentiful in season. This demonstrates the fact that man's influence is not always for the bad. The use of nesting places provided by the University buildings has increased their numbers so that they are now the commonest swallow about the marsh. 
The surface of the water around the canoe is covered with debris, mostly small material. Cattail leaves, pieces of submerged plants that have been broken off by storms, floating duckweed, fragments of shore plants, odd things such as a moth's wing, moulted feathers, and floating pollen are part of the mixture, most of which eventually sinks, for there is no current to carry it away and little wind to transport it. I would like to know the depth of material that is annually added to the marsh floor, how much of a deposit it would make after it had settled and become thoroughly consolidated. How long does it normally require to raise the bottom an inch? I have seen many so-called drowned lakes in the mountains, but their disappearance was almost entirely due to the material carried in by flood and avalanche. Except where man dumps material, the marsh is an example of an area being filled by its own debris, almost uninfluenced by outside contributions.

I hear the loud and, to me, joyous call of martins overhead. I have not visited Green Lake this year to see if they have begun their annual gathering in the willows at the south end. As many as eight thousand birds have been estimated to sweep into the low trees at dusk. They may be seen coming, high in the sky, from all directions, and bound for this one meeting place on the shore of the small lake inside the city limits. There they fly and mill about until just before dark, when they drop into the trees with a noise that resembles that of a breaking wave. Early in the morning they leave and return, probably to the places where they have nested. Will they continue to come to the Green Lake willows? The city has recently erected a concrete structure for viewing water sports at the edge of the lake less than a city block from the trees where the concentrations took place. Perhaps this spectacular roosting, the only one ever reported in the Pacific Northwest, will come to an abrupt ending.

A bullfrog calls from inside the marsh. I wish that the call 
could be heard more often. It is a common sound in many parts of the East, but its hoarse deepness astonishes and startles every visitor to the marsh who has never heard it before. I used to see hundreds of their tadpoles, but I have not seen one for two years.

Bubbles come up from all over the cove. Sometimes they are so regular, small, and evenly spaced that they look like rain drops. Today they vary in size. Some are as big as a teacup and reach the surface with a faint gulping sound; others rise in a little cluster that agitates the water and makes it appear as if a group of small fish were playing at the surface. There must be a tremendous amount of decay taking place on the marsh bottom during warm weather. I am informed that one product of this disintegration is marsh gas, scientifically known as methane, and that it is inflammable.

The hours pass as I watch and take my ease. I hear the high call of a hairy woodpecker, a rolling repetition that somewhat resembles that of a kingfisher but lacks its harshness. The campus bird list, written some years ago, calls them scarce. But since the pamphlet was issued the trees in parts of the area have made considerable growth, and now these white and black woodpeckers are frequently seen.

My eye catches movement on some debris floating near the canoe. I lift the small bit of vegetation and discover a tiny brown grub, plump in the center and tapered almost to a point at both ends. I put it on the gunwale. When it starts moving I find-much to my surprise, for it appears too fat for such bending exercises-that it is a "looper." It projects its anterior end forward in the air, then lowers it, and draws its rear end up and repeats the operation. I stir up the vegetation with a twig and find a dozen others feeding on this small bit of floating waste.

I keep watching for young carp but see none. In fact, I have never seen any in the marsh in spite of the great amount 
of spawning that goes on there. What is the period of incubation of the eggs? How old are the young fish before they leave for more open water? A friend of mine in the fisheries department has told me that a year-old carp will weigh a pound. He also said that the carp eats certain parasitic worms and helps to control the disease in fish called distomiasis which is due to that worm. And to think that I have spoken badly of the carp!

A coot, completely black, except for its white bill, leads its one chick along the edge of the cattails. The young bird is reddish in color and looks nothing like the parent. I rarely see them when so young, for the old birds are wary and do not allow the chicks to stray far from cover. The birds may have discovered the fat grubs. They pick rapidly at the floating vegetation and pay no attention to me and the canoe. A mallard hen makes a great noise as it lands nearby and sends them into the cattails.

I hear the call of birds above me and look up to see nighthawks flying. Their high lisping note sounds continually, and the white patches of the underside of their long wings can be seen plainly as their bodies, blackish-gray and brown, swing back and forth in their search for food. Apparently some marsh insect has hatched in quantities large enough to attract these adept hunters. They are members of the goatsucker family, and are like the nightjars so much referred to in English literature. They come close, wheeling and twisting in their flight.

I look at my watch. It is nearly five, and although I hear the call of the pied-billed grebe again and see a bittern flying low, it is time for me to go. In half an hour I am at the canoehouse float.

I typed my notes in much more detail than usual and mailed a copy to my friend. He met me about a week later. "Those canoe pillows," he said. "Are they soft?" 
"Like the mattresses the motels advertise. And the manager even puts in a blanket to pull over you if you want it."

"I'll try it sometime," he said. "That prospect of a marine nap rings the bell. And that report you sent: it's as long as a chapter in a book. You went to a lot of trouble for me."

"Don't flatter yourself," I said. "It wasn't for you. I always make notes and these were longer than usual because I stayed in one place."

"What do you make notes for?"

"For a permanent record, I guess. I'm always trying to compare what I see today with what I saw some time ago. The simplest way it to put facts in writing where I can always refer to them."

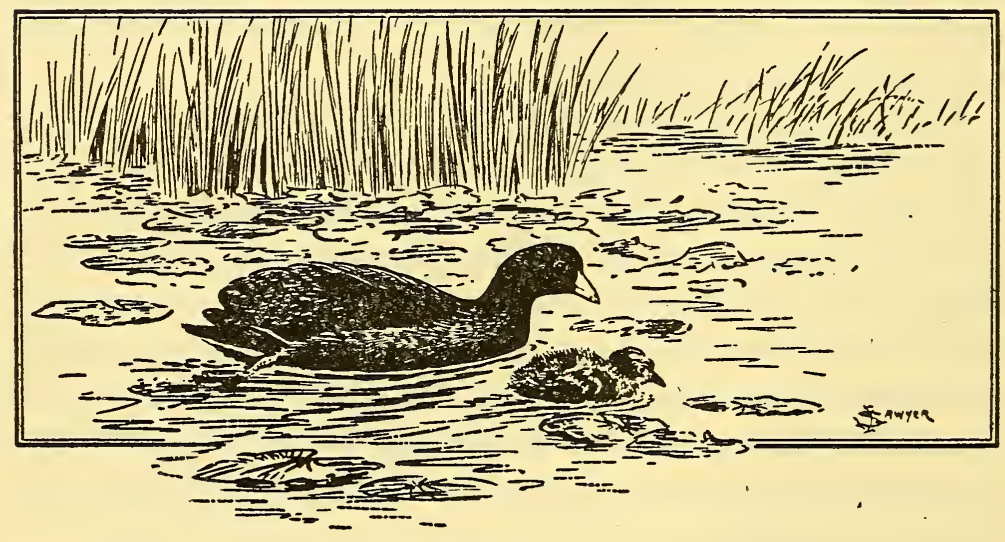




\section{How a New Water Witch Came to the Marsh}

\section{5.}

AUGUST HAD COME, THE MONTH OF activity which caused me to spend more time in the canoe than I really had to spare. I paddled through the canal for the tenth time in as many days. Then I poled quietly through the lily pads and toward the floating nest which I had been keeping under observation. My canoe almost touched it before a dark bird slipped off the pile and dișappeared instantly and noiselessly under the water among the lilies. I looked at the nest. Yesterday it had contained six eggs. Now there were only five. Was this to be the day? Was I to witness the hatching that I had taken so much pains to prepare for?

For ten days I had inspected the nest of this small diving bird called the pied-billed grebe, a resident which could easily be identified by its dumpy brown body, almost total lack of tail, and its snake-like head. I wanted to watch the emergence and behavior of the young chicks. I knew there was little possibility of being present when the great event began, but I thought that if I made repeated visits until the first egg had hatched I could then remain at the nest until at least one of the other eggs opened. Nothing had happened until this Sunday morning. But now the slimy floating 
nest lacked one soiled brown egg, and it was quite evident that this was the time for me to stay on the job. I could have picked no better day: the sun shone, the light breeze was comfortably cool, and the water still.

I returned to the canoehouse, made the short drive to my home, packed a lunch, my equipment, and a book, and returned to the nest. I found everything as I had left it.

I made my preparations unhurriedly for I anticipated a long and perhaps tedious wait. I placed the canoe in the lily pads in the proper position, then put out an anchor at both ends and further steadied it by forcing the paddles into the mud close to the boat. I decided where I wanted to use my movie camera, measured the distance from the spot to the nest, and calculated the proper exposure with my light meter. I knew that it would be difficult to get a good picture, for the nest was a dull greenish-brown, the eggs were a soiled tan, and the newcomer would be inconspicuous against the background. There would be no decided contrasts to bring out the detail. Since I was not in a movie studio, there could be no chance of manipulating lights and reflectors. I would have to photograph under natural conditions and hope that the result would be reasonably good. These preparations completed, I looked around me.

I was at the side of a platter-sized floating nest in the middle of a fifty-foot circle of blooming water lilies. To the north lay the residential section, to the south the marsh, to the west the University grounds, and to the east the bay and its opening into Lake Washington. Running through the bay in an east and west direction and only a few rods from the canoe stretched the Lake Washington canal.

A strange place, I thought, to be photographing wildlife! Much better, it would seem, as an area to get material for an article on sports possibilities in the Pacific Northwest! As if to confirm that thought, a cabin cruiser came through the 


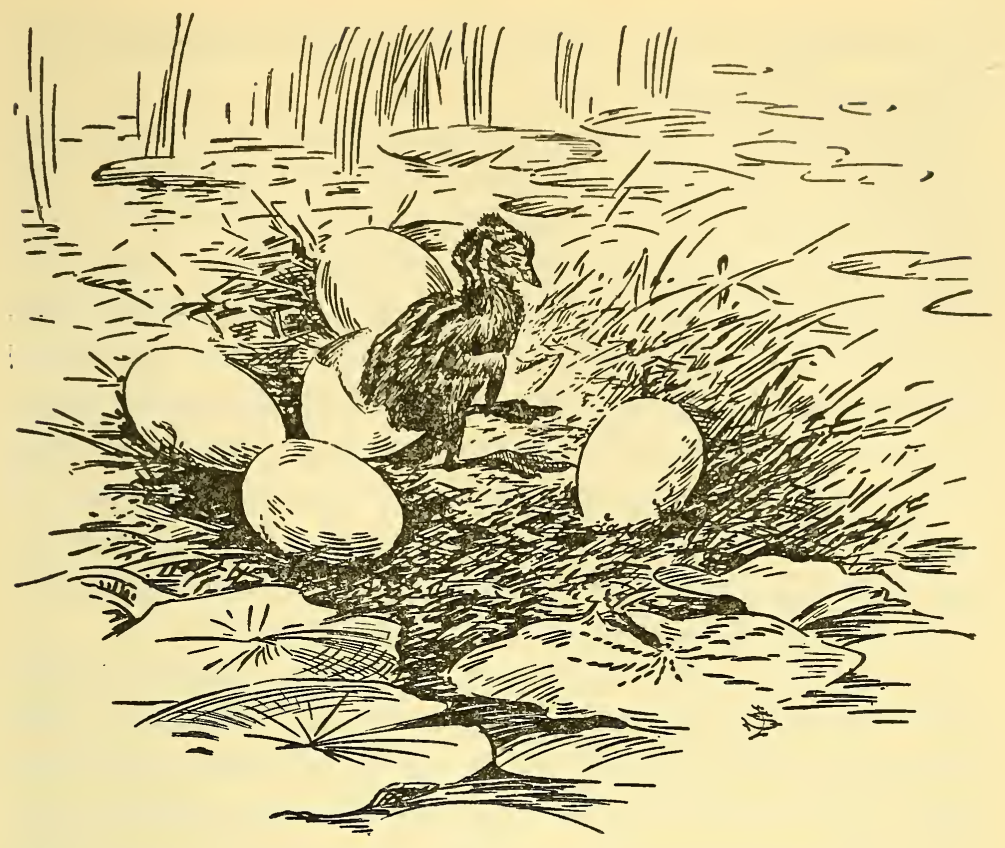

canal with its crew gaily singing. At the conclusion of the song there was a splash and five empty.beer bottles struck the water. Three sank but the gentle breeze began to move the remaining two in my direction while the boat moved on. I could hear the songs until the boat passed under the bridge. Canoes and skiffs carried picnickers through the canal, power and sailboats were filled to the limit, and an excursion steamer passed, its decks crowded with interested tourists. A dog chased a ball thrown by its master on a lawn across the bay. Automobile horns sounded from streets on three sides of the water.

Little speedboats stirred up surprisingly large waves, which would have wrecked the nest if the intervening lily pads had not absorbed their force and converted them into gentle swells on which the loosely tied and floating structure easily rode. Students from the nearby training field made 
practice flights. Sounds, odors, and activities emphasized the presence of human life.

There I was, on that August day, alone in my canoe, just outside all this clatter of planes, boats, automobiles, and songsters, waiting for a new pied-billed grebe to emerge from a small egg in a soiled and disheveled nest composed of soaked and partly decayed vegetation. Nothing disturbed me where I sat. The activity was at my back. I faced the quiet nest and its five eggs, and behind that the smooth water of the marsh inlets, the lazy movement of the cattails, and the yellow of blooming beggar's ticks. The human life passed me closely, but when I turned I watched it in the same way that I would have peered in at the action from outside the glass walls of the sound room in a movie studio.

I began to read an old copy of George Borrow's Wild Wales which I had brought along with me. I was soon with him on his walking tour through the high country of Wales, a trip which was somewhat interrupted by the constant passing of the anxious parents which continually uttered their plaintive keck. Sometimes they came so close that sudden fear conquered their anxiety; then they would stop and, with no agitation of the water, sink out of sight. Sometimes, and equally quietly, they would look over the situation by just projecting their heads as a submarine might project its periscope. Their vertical control was remarkable: specific gravity apparently was changed by a slight compression of the body so that, at will, they could sink just as a water-logged piece of wood might sink, without external effort or movement. Then they would go silently into the rushes and remain out of sight for half an hour or more. I am no disturber of nests and would have left this one had I thought my presence might have caused them to desert it, but I knew that the brooding was so far along that nothing would induce the grebes to quit. I was also sure that there was no danger of the eggs chilling in the warm sun. 
I read for perhaps three-quarters of an hour and then put the book away. It was too much like taking a radio to a ball game so that I could listen to the report of another game. The highlands of Wales, whose beauty had always absorbed my attention, could not compete with the clear notes of the robins, the sight of a busy spotted sandpiper teetering along the pads, the passing of the gulls, the delicate foliage in the water below, the freedom of the open air, and the cushioned canoe. Together, they provided relaxation that called for something other than books. It was enough just to sit and wait.

I did not turn when I first heard the noise of an oarsman behind me. Small boats explored the marsh nearly every day. They splashed along steadily and seldom stopped. This one was an exception, for I heard it push into the bank of the little bay, and then the sound of oars being pulled into the boat. Quiet followed. When I looked up a few minutes later, I saw a small boat and a college-age girl. Her hair was light, her blue costume comfortably scanty, and her tan indicated many hours in the sun. She was busily sketching the scene before her. She did not turn my way and I did not speak.

I looked at the nest and saw one egg move perceptiblyundoubtedly something would happen soon. I checked my camera and the canoe position again to see if conditions had been altered by the movement of the sun. The girl's concentration on sketching had not been quite so intense as I had thought, for a clear voice said:

"If curiosity kills people like it kills cats, I'm afraid it's going to be all up with me. I've tried to guess and can't decide what you are doing. Would it break any rules to tell me?"

"I'm hoping to photograph a young bird as it comes out of the egg."

"My word," she said. "It's no wonder you are busy. Do you mind if I come a little closer?" 
"Not a bit. Bring your boat just inside the pads. I'll hand you my binoculars on a paddle and you can see the show just as well as if you had a ringside seat."

The girl talked little, but I did learn that she worked in a downtown office and came often to the marsh to sketch. I answered her questions: the bird was a pied-billed grebe and was widely distributed over the American continent. I had seen it in the East, in Texas, and on Lake Pátzcuaro in Mexico, had wondered if it nested there and, if it did, how the eggs and young could escape the many water snakes which swam about in the shallows. The word pied-billed referred to the black band on the bill, and the word grebe was said to pertain to the crest which decorated some of the other species of grebes. This bird had no crest. Its common name was hell-diver, or dabchick, or water witch. It looked like-I pointed to one of the old birds near the bulrushes. It nested regularly in the marsh but probably did not spend more than a third of its time in the open. It was late for a grebe to nest, so late that this was almost a record for the state. People did not eat grebes. They had no particularly harmful habits. If they had any use, aside from their beauty and interest, it was as a target for hunters who could not resist shooting at any moving object regardless of its inoffensiveness. There were probably a dozen pairs nesting in the marsh. I knew because I had heard them calling during the mating season. It wasn't a duck, though it superficially resembled one. A duck has fully webbed feet, while those of a grebe are only partially webbed or lobed. They didn't sing - even their best friend would admit that. They had a call which sounded something like the barking of a small dog.

A teen-age operator swung his speedboat into a turn which drove a breaking series of waves toward us but, as before, the lily pads reduced them to quietness. I ignored him and he did not repeat the swing. Had I raised a fuss he 
was of the age that would have made him repeat the process to show how little he cared for my objections.

The egg moved considerably. I pointed to it. The girl looked and nodded.

"It's a regular drama," she said.

It was a regular drama. New wild things were about to come into the world in the midst of disturbing speedboats, curious humans, and all the hazards of weather. There were many predators which would like to find them-fish, birds, and mammals. Hungry creatures would daily scan all likely places where such events might occur, and if they found the eggs or young quick destruction followed. Many times I have found an empty and sometimes torn nest. It amazed me that these locations ever escaped the predators, even though the sitting bird blended well with the surroundings and pulled vegetation over the eggs when it left. I was sure that tragedy must have already struck at this spot, for I heard no sounds from, and caught no sight of, the bird out of the first egg. It should have been close to the place where it was hatched, peeping its high note and watching for its parents and food. Something must have removed it on the first day of its existence. Something almost always happened to part of the nestlings. The individual bird's fate had no place in the consideration of the perpetuation of its kind. There must be enough eggs laid and enough young birds survive to insure the continuance of the species, and if this survival was sufficient, the fate of the nonsurvivors seemed of little importance.

There were still five eggs in the nest. Another bird was soon to appear to increase the hatching percentage. A hole opened and a sharp-tipped bill projected. I heard the thin peeping of the inmate. The girl had the glasses to her eyes and I turned the cracked side of the egg toward her so that she might watch it better. She nodded her thanks. The one 
egg tipped and swayed, but the others remained as motionless and inanimate as if they had been made of china.

I photographed the action. In the hatching I had witnessed a couple of years before, the egg had been ringchecked and the process of emergence required more than ten minutes because the young bird had difficulty in freeing itself from its cell. This hatching was a thing of speed and precision, for in less than five minutes after the first projection of the bill the last convulsive struggle ended and the throbbing bird lay beside the two halves of the container. It had come from a shell about an inch and three-quarters long. It would have taken an engineer to figure how it could have been stored in so small a space.

This bird was not helpless and naked like the young tree swallows I had discovered the week before in an old piling. This infant was precocial, that is to say, it was born fully clothed in down and capable of leaving the nest. Its feet were huge for so small a creature and must have taken up a considerable part of the egg space. Its body was completely covered with black and white down, and its large bill was tipped with an egg tooth, a shell-breaking tool discarded soon after birth.

The newcomer lay motionless for a few minutes, paying no attention to the camera when it was near, or to me when I lifted it carefully and changed its position a trifle. The sun shone upon wet and badly disarranged down. The infant was not dainty in appearance like a young chicken. The strange quarter-inch stripes, the tousled appearance of the head, and its huge feet and bill gave it a tough appearance not usually associated with an infant of any kind. As young as it was, it displayed strength and energy, and proved it by struggling over the rounded top of the nest and down its sloping sides to the water.

"Don't tell me," said the girl, "that it's bath time already." It wasn't bath time. The bird paused at the water's edge 
and remained motionless for a time. Then began a series of struggles in which the greater part of the nest was covered. Projecting vegetation blocked the way, feet became entangled in little loops of nest material, miniature hills proved too steep to surmount and had to be detoured, rests were necessary. All difficulties were successfully negotiated and in a way which spoke well for the endurance and strength of the young explorer. The bird heaved and struggled and looked about with its large baleful-appearing eyes. Although the sun shone brightly, the plumage did not dry rapidly and still retained its disheveled aspect.

At first the grebe showed no consciousness of my presence, but when I passed a stick in front of it about an hour and a half after its emergence the bird would shrink from it. At the end of another hour some reflex would cause it to strike at the stick with its bill. I hoped to see it enter the water, but in spite of many approaches it stopped at the brink.

"No bath today, I guess," said the girl. "And I am afraid that I will have to be going. Thanks for this inside show of wildlife. I'll never forget it."

I waited for another hour, but by then the light was no longer suitable for color photography and I pulled up my anchors and left.

I returned to the nest the next morning. Only two of the muddy brown eggs remained. The shrill peepings of young birds from the lily pads explained why. I had trouble finding the newcomers. I searched for probably ten minutes before I located all three of them, the two younger ones almost covered by the rolled edges of lily pads and the bird of yesterday floating on the shining water and sprawled out like a frog.

The old birds did not show the timidity of the previous day. They came close enough so that the black band on their 
bills showed plainly. I could see the brown of their eyes in their snaky-looking heads. They uttered their anxious alarm notes, then would submerge and come up near the canoe to watch me again. They are normally very wary and timid, and I suspect that it is only in the first days after the hatching that the old display this boldness. When the young are a few days older they respond to calls and, after they have climbed on the old birds' backs, the whole party heads for the shelter of the rushes.

The parent birds did not settle down. From time to time they would approach and beat the surface with their wings to produce splashes which sounded like plankš being thrown into the water. The noise produced startled me. Air, imprisoned by the wings, must have been released as they struck the water. The resulting sound was as loud as the explosion of a paper bag.

Once I had located the young I had no trouble in watching them, for their incessant peeping indicated their exact position. They did not conceal their presence. In such circumstances many birds would flatten out and lie still, but these young grebes did neither. They crawled clumsily about on the pads. The bird of the day before could be easily recognized. Its appearance was much different from that of the late arrivals: its down was smoother and its whole appearance smarter. Perhaps this was natural, for it had lived several times as long as the others. It was twenty-four.hours old while the other two may have been out of the egg for only three or four.

It displayed more wariness than the younger birds. When I moved my camera forward it dived and disappeared under the pads, and then I saw it come into the open for a yard or so before the pads concealed it again. I could not relocate it until I heard its peeping. It was close to the canoe. I pushed it out a little way in order to take a picture. It dived again, not a bad performance when I considered that it was not 
much bigger than a wrist watch and that these dives were probably its first.

I found it again alongside the canoe. I tried a new plan by scooping it up with my hand and placing it on my windbreaker inside the bow of the canoe. And there it sat. Just a baby bird, but what a baby: uglier than the ugly duckling of the fairy tale, clothed in down, striped like a convict's costume. Few would think it related to the sleek but drabcolored parents which hovered about in the cattails. The bird kept its eye on me and did not move.

To pose quietly while I took a few pictures seemed all the concession it was willing to make, for suddenly it climbed over the margin of my coat, leaving behind an oily spot which the cleaner never succeeded in removing. I put the bird back on the garment but it would not remain. It was through with art. I, too, thought that it had done its share and so I dropped it into the water. My work was about finished and I put the canoe in motion.

I turned when I had gone about a canoe length. The game was not over for my young friend. There it was, its small body shaking with the effort of following the canoe. I stopped for a moment, then paddled again. The bird resumed its pursuit.

I picked it up and took it back to the lily pads. It followed again as I left.

I could only speculate over the reason for its actions. Perhaps it was that the world seemed too wide and sunny, too unprotected and public. The overhanging side of the canoe offered comparative darkness, quietness, a feeling of protection, and solitude. It may be that instinct warned it that open spaces meant hawks and other predators.

I couldn't let the little fellow venture beyond the reach of its parents. It might have stopped within a few feet, but I picked it up and pushed the bow of the canoe into the lily pads. This time I dropped the bird into the nest. 
It must have felt a sense of security there, for it made no attempt to follow. It peeped vigorously and appeared contented. As I paddled across the still waters of the bay I marveled at this small creature which, though less than twenty-four hours old, had already been through adventures never before experienced by any of its kind in the marsh.

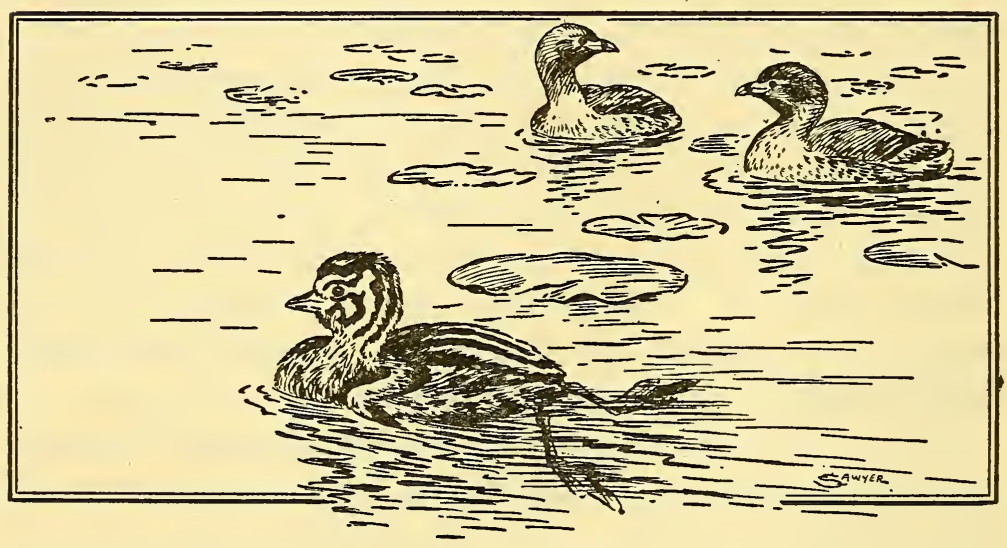




\section{Teeters, Nods, and Bobs}

\section{INTEREST In the ACTIONS OF BIRDS}

and mammals is not always proportional to the importance of those actions. Frequently it is based on simple curiosity because the purposes are not easily explained. I suppose that it is really not imperative to know why birds engage in those regular spasmodic or jerky movements known as teetering, nodding, bobbing, or dipping. I suspect that if the movements were explainable the solution would be of no direct benefit to mankind, and that if I would mention it to our somewhat blasé youths they would merely answer with two pungent words, "So what?" But personally I never see an otherwise normal-appearing bird begin to teeter, bob, dip, or jerk, without wondering why such mechanism should be built into an animal. I have always wanted to know why these apparently useless and nerve-exhausting habits belong to many species of birds and are as much a characteristic of that species as their color, the length of their bills, or their internal structure.

I have heard many people speculate on the cause of these movements. I suspect that much of the interest is due to the theory that among people such twitches, involuntary move- 
ments, and jerks are usually a sign of weakness or illness and sometimes very serious illness. Some who casually watch a bird perform think it is an action peculiar to that individual. As a matter of fact many kinds of birds make like movements in a greater or less degree, and anong the shorebirds there are some whose life is a continual "dipping."

Four birds with such habits regularly visit the marsh. One is there nearly all the year, the others may be seen usually in spring, but are almost certain visitors in August. Chief among them is the spotted sandpiper, said to be the most common sandpiper in the United States and certainly the most common one in the state of Washington, where it can be seen in season on almost every pond, stream, and lake. When I faltboat on a western Washington river I flush them from almost every sand and gravel bar I pass. I watch their twinkling curved flight as they lead me for a few rods before they return to the upper end of the bar. Sometimes I have watched them feed along the stream margin, always active, almost always moving along as they feed, their small asholive bodies held low, and the large brown spots on their whitish underparts identifying them instantly. These birds utter a series of mellow notes as they fly, notes so distinctive that they are frequently called peet-weets. But most distinctive about them is the almost continual raising and lowering of the rear end of the bird, a process so noticeable that it has been given descriptive names such as tip-up, teeter-tail, teeter-peep, tilt-up. Elliott Coues, in his Key to North American Birds, has described this action more clearly than any other ornithologist I have read.

As often as the Teeter-tail stops running, the foreparts are lowered a little, the head is drawn in, the legs are slightly bent, while the tail bobs up with a jerk, and is drawn down again with the regularity of clock work-as if the tail were spring-hinged, always liable to fly up, and requiring constant presence of mind to keep it down decently. It is amusing to see the male perform during the mating season, swelling with amourousness and self-sufficiency till it looks twice as big as 


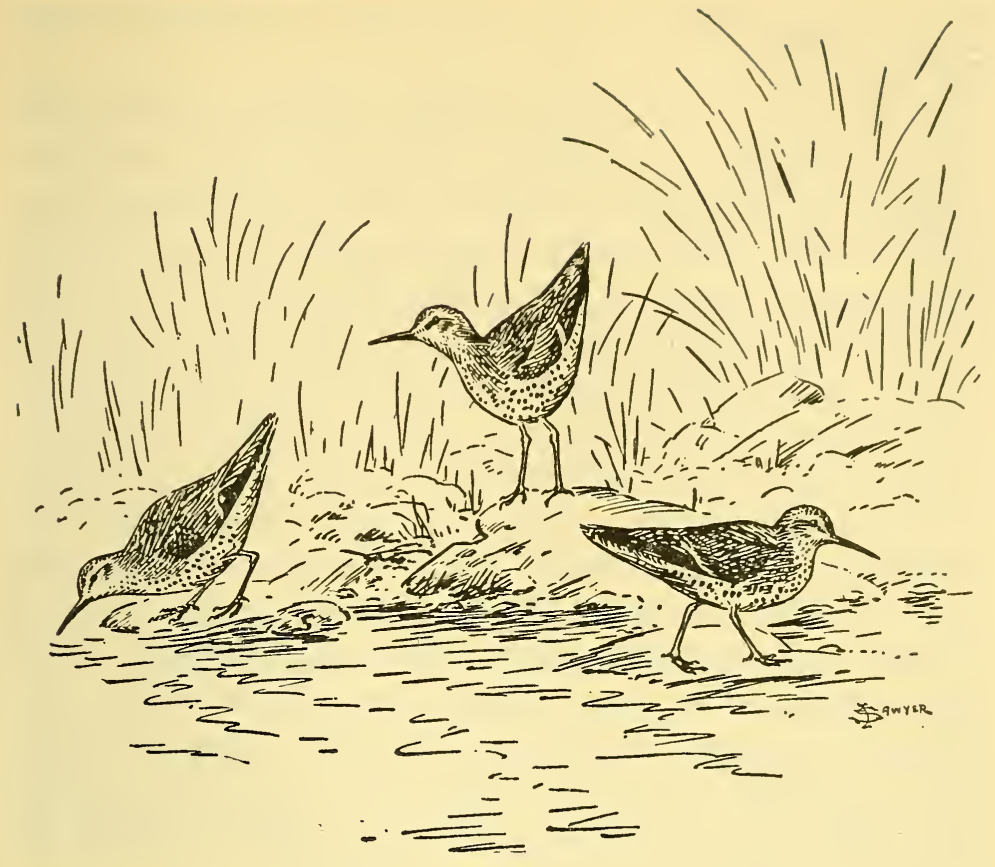

usual, facing about this way and that, saluting. all points of the compass with its hinder parts-for such is the original way the tip-up has of conducting his courtship.

I have been told, though I have never seen it, that hardly are the young born before they assume the habit of teetering, and when they are merely balls of down they can be seen running about wagging their tails. I have also been told that they cease teetering when they hunt and are ready to take an insect, but I have never noticed it. For me, the spotted sandpiper will always be the bird with the unstoppable tail. When they come to the marsh-and I have seen them every spring and fall for years-I have watched them move from stranded log to log, to lily pads, never far from shore, always giving their pleasant peet-weet and always teetering. When I first saw them I wondered why they were never still. None 
of the reasons I have since heard have completely satisfied me.

Of the other marsh guests which engage in such movements, the killdeer has always seemed the next most conspicuous. If the habit is due to nervousness I have never known a bird which might more properly bob and dip. Its species name, vociferus, is properly descriptive of its habits. Its local names are noisy plover, chattering plover, and one writer has described it briefly as "a very noisy bird." If it was in the marsh I did not have to see it to know it was there. Sooner or later I have always heard a kill-dee or a kill-deer uttered and reuttered in a high pitched tome, usually. followed by a trilling deer-deer-deer-deer, repeated time after time and at an increasing tempo. If a bird can be described as nervous, it is this talkative, fluttering show-off, which goes into a tantrum every time its nest is threatened, next wallows on the ground when the invader is close, and then flutters, struggles, and cries madly if the aproaching person gets within two or three yards of the sand or gravel depression in which the four eggs are placed.

I have seen the killdeer many times in August, and as I watched, it would raise and lower its head while the rear dropped correspondingly, an abrupt and rough movement with no apparent useful purpose. It frequently repeated the act, oftentimes while it was walking up and down a flat and protesting the approach of the canoe or when standing on a bit of driftwood. I have always considered the bird a handsome creature, and especially when the sun shines on its conspicuous markings-a general brownish color with two black bands on the breast, much reddish color on the tail, a white stripe on the forehead, and a white ring around the neck. The underparts are white, the bill black, and the legs grayish-brown. The dignity of its appearance, in the rare moments when it stands still, vanishes with the resumption of the convulsive jerk and bob. When the killdeer becomes 
really demonstrative, it can prove quite annoying, for it usually sends the nearby birds into the air with a rush of wings which takes them far from the place where the canoe lies.

Two shorebirds, the greater and the lesser yellow-legs, are the other bobbing or teetering birds among the marsh visitors. I never fail to see them in August. The two birds differ little and in the field can be told apart only by size and by their calls. The lesser yellow-legs approximates the size of the killdeer while the greater is somewhat smaller than a curlew. The smaller bird gives a call of two notes, but that of the other always consists of at least three and occasionally four. The quality is surprisingly mellow and pleasant and most distinctive. Both the smaller and larger birds which I saw this year landed on the same flat but on different days. They lacked the activity of the killdeer and they showed none of that bird's nervous traits unless the bobbing action can be so classed. They bobbed, less frequently than the killdeer, but fairly actively and regularly. I found them wary and did not try to bring my canoe too close, as I knew that they would burst into the air and leave. A more distant station and the use of the binoculars was always more satisfactory. Once, when I had beached my canoe and was watching some long-billed dowitchers, a lesser yellow-legs dropped down on the little bar and joined them. Evidently it had been the movement of the approaching canoe and not the sight of me that had alarmed other yellow-legs, for this bird ignored me and my motionless craft and fed, sometimes within a yard or two, for at least half an hour. Then it took a short tub and settled down to a sleep which did not break when I pushed out my grounded canoe and left the spot. It stood there, with half of one orange-yellow leg under water, the other pulled up into its body feathers, the white of its tail base showing plainly. It was a handsome and sturdy bird, which gave no impression of any nervousness that might provoke its seemingly spasmodic actions. 
The four shorebirds just described do not include all species in the state that indulge in such practices. I have seen hundreds of pipits, sparrow-sized land birds, raise and lower their tails as they sat on projecting rocks among the withering alpine plants of Welcome Pass. The birds had assembled there in late summer to feed on the thousands of grasshoppers which had so far escaped freezing weather. In other parts of the United States certain flycatchers and the ovenbird, a warbler, display like movements. The willet, a shorebird never seen in the marsh but an infrequent visitor along the ocean beaches of this state, and recently seen near the Government Locks, exhibits this same habit. Also, in this state, the water ouzel, or dipper, bobs and dips along all the mountain streams. It has not been seen in the marsh, but unquestionably will be, sooner or later, because it has wintered at the mouth of the locks less than five miles away. Since it is the most characteristic and possibly the best known of the dipping birds it is worth a description.

It is a chunky bird, a trifle smaller than a robin, and of a family closely allied to that of the robins. It lacks the webbed, or partially webbed, feet of typical swimmers, but it is a master of turbulent water. The dipper dives into the swiftest and roughest parts of mountain streams, crossing from rock to rock by swimming above or under water, disappearing in eddies, and staying there for an unbelievably long time. When it is pleased with the food, one dive is followed by another. It sings often. Few songs are sweeter. They are even delivered when the banks are snow covered and the slower portions of the stream frozen. The white outer membrane which can be pulled over the eye makes the face look like a Negro minstrel's. To my mind, the bird is an exceptionally accomplished stream resident and one which I never cease to admire. It appears to have the strength and steadiness of nerve required to take a living from such unusual and difficult surroundings in every sort of weather. 
I have seen it busily examining the small expanse of open water in a mountain lake after the cold November nights had frozen all but that one small area. The bird dived and reappeared as if it were bathing in the summer warmth along the creeks in the valley below.

These birds are tough little fellows, and I could never understand why, when one was standing on a rock, its legs would suddenly drop as if somebody had crept up behind and hit the joints so that the body sank an inch or so. Then the legs would straighten and bring the bird back to its normal position. This action was repeated several times a minute. The only time I have seen the bird when it was not bobbing was when it slept on a rock in the stream. It is no seasonable performance connected with display and courtship. Males and females, spring and fall, follow this practice. Among all the teetering and bobbing birds the style of the dippers seems the most unique, perhaps because it is usually done in the open against a contrasting background, or because the dark chunkiness of the bird seems ill-suited to such contortions.

Why do these birds of various types teeter and bob? I suspect, at this moment, many people might suggest that, although it is interesting to hear of the strange movements of these birds, there isn't much point in trying to determine why they make them.

It is a comfortable and relaxing suggestion but one with which the scientist just can't agree. Science does not progress by overlooking the things that might be called small and unimportant. Problems which are ignored because of their apparent insignificance may prove to be of great moment once they are explored. A small beginning like the examination of a sterile area in a culture medium led to the discovery of penicillin. Only continued inquiry into seemingly unrelated details developed the commercial use of rubber. And 
so scientists persist in evolving theories and in testing their validity.

Joseph Grinnell, in his Philosophy of Nature, makes these statements:

The more I reflect upon the observed actions of birds, and of animals generally, the more I am convinced that there is no such thing as wasted effort. . . Really, every movement, every phase of activity, has its explicit meaning in the bird's program of maintaining existence.

That means that such habits are not accidental or useless but serve some purpose that may or may not be concealed.

If I accepted this premise I thought that it should not be too difficult to discover why our spotted sandpiper went through its sinuous bobbing motions. The bird's problem is to maintain existence. Food, shelter, survival, and reproduction are concerned with this problem. There should be some simple connection between these motions and the bird's needs.

I recalled the people I have talked with and the books and articles I have read. I was quite impressed by the arguments of a physician, a serious bird student with a great interest in optics. He said that when a person tries to look beneath the surface of water he invariably raises and lowers his head until it reaches an angle which gives him the best view. He thought it quite likely that shorebirds bobbed and teetered to obtain the same results. It appeared to be the móst reasonable explanation I had heard, but it hardly explained why the pipits wagged their tails while hunting grasshoppers on the heights of Welcome Pass.

I found a statement by Bradford Torrey:

Can it be that such frequenters of shallow water are rendered less conspicuous by this wave-like up-and-down motion, and have actually adopted it as a means of defense, just as they and many more have taken on a color harmonizing with that of their ordinary surroundings? 
Here were two men and two theories: one that the motions improved vision, another that it provided protection.

I consulted Grinnell's chapter on "The Principle of Rapid Peering of Birds." He held that the birds which hunted stationary food continually shifted their position so that the angle would permit easier location of the prey, just as a man hunting a golf ball walks back and forth in an effort to find a spot from which the missing object can be seen. This was a new theory and one which did not require a water background.

I remembered an article by Edmund J. Sawyer, an artist, a close observer of nature, and a man of tremendous field experience. He dismisses the idea that this constant habit may be an alarm signal to its kind, or a recognition mark, or a source of information. He is certain that it is not used to intimidate an enemy. The habit, he thinks, is an all-season one and a constant one, and this removes the possibility of its use for such purposes.

So far his approach is negative but he does not continue in that vein. He advances the theory that bobbing and tipping are done to increase the possibility of survival. He points out that it is confined to the smaller birds which need the advantage of a split second's start over a natural enemy. He thinks that this continued movement may suggest incipient flight and cause a premature and blundering attack by predators. He considers that this theory may account for the existence of the habit in birds which are distantly related. $\mathrm{He}$ is certain that any reasonable explanation of the various styles of bobbing and tipping must be consistent with the fact that the birds often have little or nothing else in common. And he closes with the thought that, to the best of his knowledge, the birds with this habit are all of the ground type and especially subject to attack, which would seem to call for some extra measure of self-protection-such as a moment's warning would give. 
That was all the information I could get, although I consulted every index to which I had access. Simple as it may appear, the subject is not disposed of so easily. Each of the four men has expressed himself with one of the reservations "can it be," "I offer a theory," "It seems to me," "I think"the language used by the scientist who feels that he is or may be on the right track but who wishes it distinctly understood that the theory cannot yet be considered proved.

The foregoing is a rough summary of what I have learned about teeters, nods, and bobs. I know that it will not satisfy you for it has not satisfied me. Nothing that I have observed furnishes an adequate answer. What I have read has come close to, but is not completely, an explanation. Every time I see a spotted sandpiper throwing its weight about I think, "There are a lot of people who would like to know just why you do that." The last time I fished on Hyas Lake, a dipper entered the boat, walked between me and my companion, and calmly ate salmon eggs which had spilled on the bottom. There was no excitement, no water to peer into, no alarm over safety, but, nevertheless, the bobbing went on as decisively as if the bird were nervous, the need for acute vision imperative, and the area filled with hungry predators.

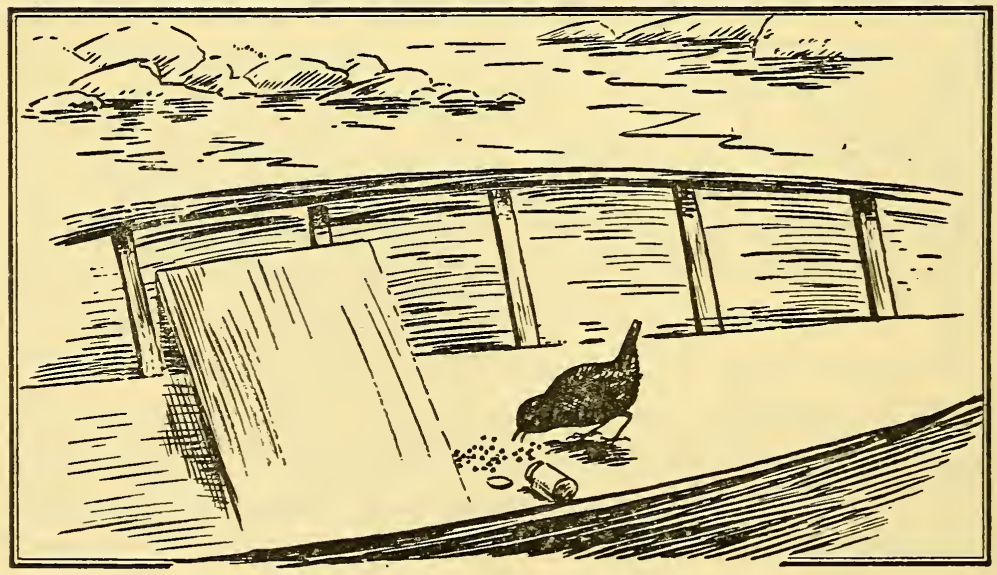




\section{How the Green Heron Wandered}

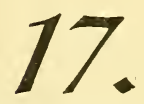

THE CANOEHOUSE MANAGER PUSHED the canoe into the water. I stepped into it, adjusted the pillows and made myself comfortable.

"Do you think you'll have an interesting trip?" he asked.

"You can never tell. Anything may turn up in August," I replied. "It may be just a humdrum day or it could be like the time when I first saw one of those fellows." I pointed to a brown-colored bird which had just dropped into a willow on the point.

I paddled across the little bay, not cutting in toward the willow but close enough to look over this hunched-up, longbilled, and dark-colored creature as it stood on a branch halfway up the tree and watched me pass.

It is rather a common bird now in the marsh, but I remembered the first time that it came and the sensation that it caused. It was one of those unexpected adventures which caused me to continue my visits. When I reached the canoehouse that morning some years ago, I had no idea that I was to meet a problem which was to prove the most interesting that marsh wildlife had yet presented. This is what happened. 
It began with the manager's statement that he had seen a curious bird, a remark that he frequently made at that time of year. It was always followed by a discussion of color, size, and general description, suggestions of possible identity, and finally reference to the two bird guides which I usually carried in the car. We were unable to settle the matter that morning for I had left the guides at home. He said:

"It's smaller than a bittern, but looks a little like one. It raised a darkish crest when it flew away, and it scolded like all get out."

If I had been in a marsh in southern California I might have thought it a least bittern or a green heron, but the possibility of those birds being in our city marsh seemed quite remote. Nobody had heard of a least bittern being resident in the state of Washington. There was one subspecies of the green heron on the Pacific Coast which might have been considered as a possibility. It had been discovered in southern California, was regarded as a desert form, and although it had been reported in our state in the past, the reports were not considered entirely reliable, and only one sight record of the bird north of the Columbia River had been accepted. This location was over a hundred miles south of Seattle.

The unknown visitor promised to be of great interest. The manager and I discussed it in every detail. For three mornings it had appeared on the float and had expertly breakfasted on tadpoles. It was the size of a small chicken but slimmer in build and its yellow-green legs made it look taller. Its bill was sharp and strongly built and was estimated by the manager to be three inches long. The bird's pose was something like that of a great blue heron, with its neck outstretched when hunting, but with body compressed and neck drawn in when at ease, in which position it appeared little more than half its height when the neck was extended. Its flight was weak and dangling. 


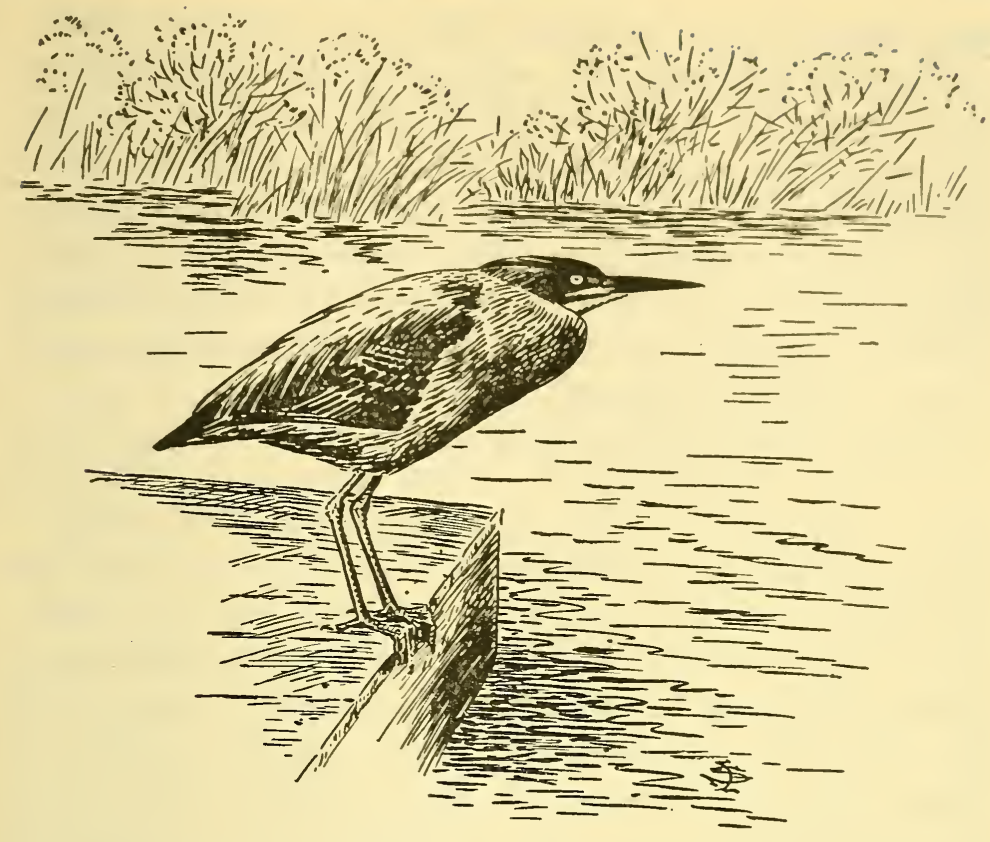

I had listened carefully to these descriptions. I was convinced that he had made a great find. I knew that there was no mistake for his statements were carefully made. I wondered if I would have a chance to observe the bird. At home that night I put three well-illustrated bird books into the car.

The manager was on hand when I arrived the next morning. We walked to the float. I could see how the heron would be attracted, for hundreds of fat bullfrog tadpoles swam to the surface and pushed their bodies partly out of water so that the surface looked as if the rounded ends of innumerable broomsticks were being projected into the air. There could be no finer hunting. But the bird was not there. We waited on a bench in the background for more than an hour but it did not come.

I decided that there was one thing that we could do while we were waiting-that was to check the bird guides. I made 
notes from the float while he looked over the three books. I did not want to make any suggestions that might influence his findings. He possessed the carefulness of an observer trained on the farm and by years of hunting. He went through the illustrations in each book with the same care with which he would have made observations in the field. When he finished he opened each book at the page he had marked. The bird he pointed to was the Anthony green heron, a western subspecies of the green heron.

I must confess that my failure to have seen the bird was a tremendous disappointment. There could have been no greater addition to my list of marsh visitors. The manager, whose apartment overlooked the float, had never seen the bird before. It might be that he would never see it again. And I had missed it completely. I had not caught even a distant glimpse of this stranger. I launched the canoe with the feeling that luck was a bit against me, but I could not remain depressed for long in such weather. One of my friends would have called it a Holland day, for the sun and the distant view were softened by the slightest suggestion of mist, the roughened surface of the water flashed its movements, and great cumulus clouds hung in the east. The breeze was fresh enough to make paddling comfortable. I cruised about the handsome blooms of the water lilies, entered some inlets to hunt for green-winged teal, and moved casually and comfortably wherever my fancy took me. But I had not forgotten the visitor; every rising bird attracted my attention. I turned quickly to get a view of it, and if at first I could not see it, I followed the sound of its wings until identification was possible. But no green heron rose and pursued its loose flight. Every cove I entered confirmed my belief that it had gone. I knew that rare visitors were usually storm-driven and that their stop was often for a day or only part of a day. This one had been here for three days -what reason for it to remain any longer? 
Some newly arrived red-backed sandpipers flushed and burst through a flock of young swallows which flew clumsily about. The swallows were driven to the canal bank and I watched them trying to balance themselves on swaying bulrushes. I had begun to feel quite proud of my ability to forget my disappointment of the morning. I had been slow in realizing that happiness in the field could only be learned by emphasizing the importance of littie things, and by believing, like the tailor in Sartor Resartus, that those who do not expect too much will be made happy by the small things that come their way.

Perhaps my philosophic acceptance had its own reward, for later in the morning and after I had completely dismissed the thought of the visitor a brown, medium-sized bird raised its blackish crest as it flew out of a willow on the edge of the cattails. It uttered a frequently repeated skee-ow, and flew slowly along the bank with its yellowish-green legs dangling. I fairly caught my breath. I think I gazed at it as a prairie boy might watch his first steamship. For there was my bird, the green heron. As usual, the manager had been correct: he had realized immediately that the bird was a stranger, and had noted every peculiarity so that he could describe it carefully.

A green heron is not a bird which would excite an Easterner, who lives where it is plentiful. It would be as unremarkable as a magpie in an eastern Washington coulee, but in our area it has the rarity that a magpie would have in New England. I had looked about with an added sense of the importance of the marsh-to think that so small an area in so crowded a location could harbor such a rare and interesting bird.

As the canoe advanced, the bird had watched from a low willow, each foot gripping a branch, neck outstretched, and eyes apparently glaring at me. I reached for my camera but before I could adjust it, the bird made a movement which I 
later found was quite characteristic. It dropped a couple of feet lower so that its position against the sky was lost and its body made only a rough outline among the branches. I waited for it to climb again but without success. I soon learned that these downward retreats were never reversed by a short climb, but were usually terminated by flight.

I recalled some of the names by which the eastern relative was known: shitepoke, little quak, and fly-up-the-creek, the last of which I thought particularly applicable to this western relative, for I followed it as it flew from willow to willow, from top branches to lower ones, and then to other trees where the bird repeated its performance. I succeeded in getting a couple of short movie shots which I hoped might establish its identity, but I knew the distances were too great to be satisfactory. Then the bird flew across the marsh and disappeared for the rest of the day.

That had been my first encounter with the green heron in the Pacific Northwest. I hoped that it would not be my last. On my way home I thought much about the bird and of the probable reasons that had brought it here. I knew that the public in general regards all birds as free to wander wherever wind and food and fancy take them. But the contrary is true: birds live within definite boundaries, more extensive for some than for others, but all subject to decided limitations. They do not often make a practice of getting out of their range, although annually there are exceptions to the rule. Herons of various kinds occasionally indulge in pseudomigrations, which are not migrations involving regular journeys between their winter and breeding territories, but are simply postbreeding wanderings which follow no definite course. Had such a pseudomigration led this bird to the marsh? If so, where had the summer nesting taken place, and how far had this stranger come in its wandering? I spent the evening in an examination of the available records.

I learned that there were two races of the green heron on 
the Pacific Coast. One of them, the Frazar green heron, was restricted to the peninsula of Lower California and could be eliminated. The other, the Anthony green heron, had been found in 1895 by an ornithologist named Mearns and described by him from specimens taken in the Colorado Valley near the Mexican boundary. It was a lighter-colored bird than its eastern relative, and at first was supposed to occur only in the arid regions of California and the Southwest. There it breeds in trees along the irrigation ditches and streams. I found that, by 1926, the range of this supposed specialist in arid localities had been extended as far north as Fort Klamath in the southern part of Oregon, and that one person had reported the bird to be a "not common resident" in Washington. The fact that the best of the northwestern ornithologists-and there were many at that timemade no report of the occurrence of this bird in Washington until many years after makes this record doubtful.

Although no green heron had been reported as far north as Seattle, I made no attempt to publicize this extension of range. It would not have been accepted as a scientific record, for there is an unwritten rule that such records should be substantiated by the actual skin of the bird. This is probably sound from the viewpoint of science. It aids greatly in keeping the records free from errors and frauds due to ignorance or evil intention, although it would not prevent an unscrupulous person from collecting skins in one district and then representing them as taken in another. I quite agreed with those who held that the indiscriminate acceptance of sight records could be responsible for many errors. Had I wished to claim a record I could easily have shot the visitor, but I did not think that the matter of proving range extension was of enough importance to justify killing the bird that had set up the record. Then I thought of testing the value of color photographs in the identification of species. Would it be satisfactory? I decided to find out. 
When the manager reported that the bird came around almost every morning, I made a series of early visits. After the third trip I learned that it spent the night in a little marginal pond south of the canoehouse. Then I had only to flush it, to watch where it landed, and to try to photograph it in the tree. If disturbed again, it would fly to another pond just north of the canoehouse, and if left alone would spend most of the day there. A small blind at this spot enabled me to take some pictures, and just after that, in the first week of September, the bird disappeared.

The statement that the green heron had been a fortnight guest of the local marsh was not received with much enthusiasm by scientific friends who had heard of it. I was not surprised. The customary introduction to such a statement is something like this:

"Here's a skin I thought you might like to see. It may be something new in the territory."

Then in due course the skin would be examined, compared, and carefully measured, and the verdict would be given.

In this particular case, after mentioning a possible new record, I was told each time that it would be interesting to see the skin. Imagine the shocked attitude of the listener when I replied that the bird had not been collected. I was reminded immediately that of course the skin was required for proof. It was not said with temper or malice, but politely, and only as a reminder that there were rules which must be observed. The fact that twenty persons had now' seen the bird was not sufficient evidence: who could be certain that the twenty had not been mistaken? The skin of the bird must be available for examination by any who wished to satisfy themselves.

It is the privilege of all to think that even a good rule may be carried too far. A green heron within ten or fifteen yards could be mistaken for nothing else by any observer of birds. I asked myself if it were necessary to collect the skin of a 
zebra in order to be sure that it was a zebra, or the hide of an elephant to prove that it was an elephant. When the processed pictures were returned I mounted the best and forwarded them to the American Museum of Natural History in New York, with the request that they identify the bird. The short note mentioned only the place where the pictures were taken. The reply stated that the bird was a green heron. The answer went as far as I had hoped and expected. I knew that the matter of subspecies could be determined only in the laboratory.

The letter satisfied me that proper photographs in color were of considerable value in identification. The report of the presence of the green heron was accepted unquestionably, especially when two records, made earlier, were published. Stanley G. Jewett, a nationally known expert, had seen a green heron in the southwestern portion of the state, and Hubert C. Hall had taken an Anthony green heron in Pacific County, Washington, on the day before the manager had told me of the arrival of the bird in our marsh. So everybody was satisfied: the precisionists had a skin to prove that its former occupant had really flown into the state, the report of the museum established the fact that our bird was a green heron, and more than that the record of the almost simultaneous appearance of these three birds suggested that significant changes might be taking place.

From a news standpoint, had the matter ended there it would have furnished only an item which might compare in importance to city news, such as the visit of the crown prince of Norway, an Australian tennis champion, or some famous explorer or statesman. But my friends and I were in an excellent position to watch the arrival and departure of marsh guests and to witness the remarkable change in the status of the green heron in our territory.

We did not, as the thorough Germans might have done, form a society for the observance of green herons, but we 
did ask all local bird observers to keep an eye out for the strangers. The manager, always cooperative, mentioned the matter to many canoeists who he thought were good observers: some were familiar with the eastern bird. But the fall of the year and the next spring passed without any further sight of our avian problem. It was not until April of the next year that the manager called to tell me that a green heron was again fishing from the float. We saw this solitary bird in various locations close to the canoehouse, always silent, morose appearing, and sluggish except when it drove its bill at great speed to capture a passing tadpole. It left during the first week in September.

It has been my custom to take notes regularly in the marsh. If I now refer in some detail to the dates of the coming and going of the green heron, it is because I soon learned that these visits represented much more than the casual roving of one individual. When the green heron appeared for the third succeeding year and remained from the middle of July until the first of November, it looked as if some sort of rough pattern was emerging and that its visits were not accidental. Perhaps it had wandered from south of the Columbia River where herons were known to nest. Possibly the bird was stopping on its return migration from farther north nesting places. Close observation might give some more information which would help to determine whether the green heron, because of population pressure, drainage of former breeding grounds, or for some other reason, was reaching out into territory far removed from its original habitat.

I was convinced that the marsh was an ideal place for such observation. The manager lived in the canoehouse and left the area only for short periods. He saw the marsh early in the day and late in the evening. He was equipped with powerful binoculars. Canoehouse Bay, with its abundance of tadpoles, small frogs, and other food, was the best feeding place in the marsh. I patrolled the area one or more times 
a week. I think it safe to say that no green heron entered the bay without being observed by the manager or myself.

The scanty information so far collected by us had upset the previously recorded time schedules of the bird. It had been thought that the green heron's fall migration from Oregon, the northern limit of its range, began early, the latest date being September 10. But this bird had been seen as late as November 4, two hundred miles north of Oregon and far beyond its "normal" range. It meant a decided revision in the status of the green heron in the Pacific Northwest.

Any thought of a regular pattern in the marsh visits was dispelled by the deviation in the next year. A bird arrived quite in accordance with the previous schedules, but its departure was decidedly out of line. I saw it through September, in October, and during the Thanksgiving and Christmas holidays. What kind of a creature was this? Why should a bird which had specialized on living in the blistering heat of southwestern river swamp bottoms remain in the north to endure the drip of fall and early winter? On each of my trips I expected to find that it had gone, but it was there in January when I went to check it after a severe snowstorm. It stood under the shelter of an arch made by lodged cattails and looked as if it had never lived anywhere else. My last sight of it was on February 11. To those who might think that this bird may have been the eastern heron which is known to winter occasionally in the northeast, I will say that no eastern green herons have ever been taken in this state; on the contrary, every green heron which has been examined has proved to be the Anthony. The American Ornithologists' Union check list says of this bird: "Breeds or summers from Portland, Oregon, to Lower California, Southern Arizona, and Northern Sonora, Mexico. Winters from Southern California, to Southern Mexico and Central Costa Rica."

I found these conditions difficult to explain. I knew that many kinds of birds did wander but more of them did not. 
It was their habit to return to the same territory, to the same field or woodlot, and often to the same part of a field or the identical tree which they had previously occupied. The departure and arrival of such birds ordinarily were quite regular. This decided upset puzzled me.

In late August another green heron arrived. I speculated as to whether it would leave on schedule. I missed it on two visits and noted its departure in my records. But I was forced to withdraw the entry. This bird was either the pioneer of the year before or another equally hardy bird, for it remained through a moderately hard winter and left in February just before the arrival of the tree swallows. I would have given much to learn its destination, its direction, and its distance.

I knew no rules which would enable me to forecast the schedule of this species. For three years it had left moderately early in the fall; for two years it had remained in the marsh all winter. I had never seen such variation and wondered whether its marsh stays would always be so uncertain. But it never wintered again. For the next four years the green heron appeared in April or May and then disappeared after a short visit. It reappeared in the period between middle July and September, and left before November 1 . This schedule may prove to be its natural one.

By this time the long legs and dangling flight, ahead of the canoe, together with its harsh skee-ow, had been noticed by canoeists and in season they began to report the presence of two or three birds in the marsh. One man stated that he had seen five, but I thought that birds might have recrossed his path and been counted twice. Several other enthusiasts cooperated with inspections and reports. One of them, a student, reported that she had seen a young heron in the neighborhood. We decided to watch carefully for nesting birds the next season.

The combined observations gave us a fairly good idea of 
the situation in the Puget Sound area. I had now seen green herons while faltboating on both the Snoqualmie and Sammamish rivers. A friend of mine had collected a specimen fifty miles north of Seattle. These, together with those taken near Tacoma, and the additional ones seen in the marsh indicated that there were now many more birds in the state than had been realized. One of the birds taken near Tacoma proved to be in breeding condition when dissected. This justified the opinion that the birds were nesting somewhere nearby. We could now believe that the appearance of these birds was not due to pseudomigration, but was a part of a definite movement into Washington. This belief was strengthened by the presence in the swamp of twelve birds in one day.

The next spring four green herons appeared early in the marsh. We saw them through May and June but could not locate a nest. Then on June 18 , while paddling through a canal, I saw two strange birds sitting side by side on a willow branch, their bodies silhouetted against the sky, and the light shining through their crowns like a halo. I had not found the nest, but here were two green herons, so young that it was certain that they had been born in the marsh. Their tails were stubby, their wing feathers short, their bills light-colored, their breasts striped with tan on either side. The identification was easy because my six-power glasses brought out every detail. They half fell, half climbed, down from the branches and disappeared. I returned now and then for two hours, each time seeing them back on a branch and each time watching them slip down again. And throughout the week I saw them in almost the same place.

It had been just a few days less than ten years since the canoehouse manager had directed my attention to the first green heron in the marsh. My friends and I had watched its invasion of the territory, had heard of its increase in other locations in the state, and had welcomed its visits to our 
local marsh at strangely different times and under greatly varying conditions. We had watched continually from the vantage point of a small city area, and had been rewarded by witnessing an unusual and continuous demonstration of the outward thrust of a species which now promises to be a regular resident of the state.

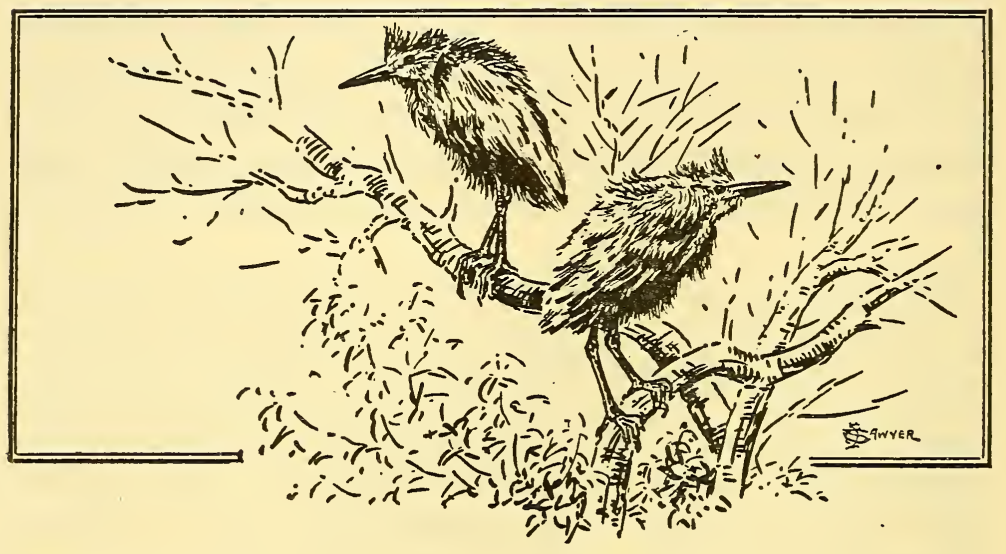




\section{Marsh Symphony}

\section{8.}

THERE ARE, OF COURSE, GREAT physical differences between a marsh and other natural features such as seashores and mountains. There is also a decided contrast in what might be called the tempo and the appeal of the areas. I had often thought of it, but, strangely enough, it was not until a morning in August, when I witnessed the episode of the venturesome house dog, that I concerned myself seriously with the matter.

The dog was a Boston bull, a member of the family of one of the professors, with all the pamperings and privileges connected therewith. It possessed the rather irritable combination of cocksureness, faith in the goodness of human nature, and the faculty of taking everything for granted, that invariably marks the well-treated and young city dog. It came to the marsh with its master and looked over the place while the professor talked with the manager. It sniffed and approved the various posts, walked around the canoes, ignored the two country-wise spaniels of the manager, and then turned its attention to the float.

Apparently the dog had been accustomed only to clear and weedless conditions, and its experience had not included 
water so thickly covered with floating growth that it looked as solid as the path over which it had just daintily romped. Accordingly, when a cottonwood leaf danced lightly upon this most deceptive surface, the dog moved quickly to inspect the moving object. The leap was just the proper distance. Had the surface been firm the animal would have grasped the leaf as it landed. I had never seen a dog before that I could swear was surprised, but when its head appeared above the surface with green strands decorating its forehead and with its ears and nostrils full of duckweed, it wore an expression which any movie director would have accepted as a perfect interpretation of astonishment. Many square feet of this tiny plant growth had to be pushed aside by the dog as it swam to the landing. There it retired to a corner of the float and scratched and shook and licked itself into some sort of order while the country dogs regarded the performance of their high-toned city visitor with so much indifference that they did not move a foot or utter a bark.

The impression made by this incident was partly due to the fact that it showed me how much more a country dog knew than a city-bred animal. Mike and Bill had their daily chores to do and they did them well. They hated rats and kept them away by regular patrols of the area. They accepted strange human visitors only if they obeyed the rules of the place. They did not allow prowlers near the canoehouse and its lockers. They saw that no strange dogs molested any water birds which were obviously a part of the canoehouse surroundings. All of these things were done surely, conscientiously, and without fuss. Between times they looked and learned until they could differentiate between the regular visitors and casuals as certainly as if they had worn a distinctive costume. When I approached, they uttered a couple of short barks, a signal which the manager said indicated always the coming of a friend. When I got nearer they advanced for a friendly pat and welcome and then returned 


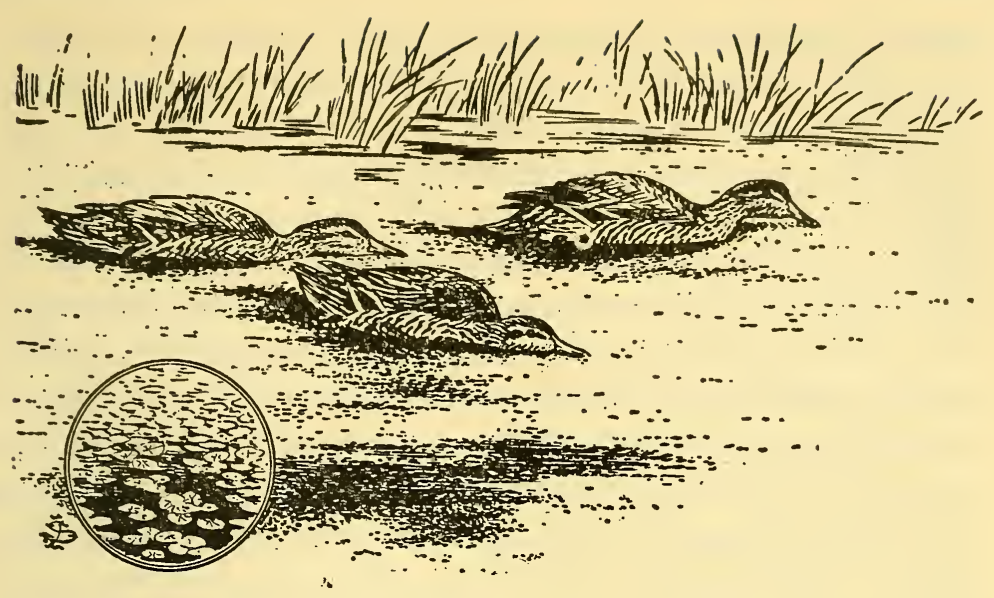

to their other duties. As for the town dog, its home life had been such that it had no difficulties to meet, no schedule to follow, no contact with roughness or unkindness, and consequently no ability to face properly anything outside the petty routine of its life.

The other impression concerned the duckweed which had so upset the dignity of the professorial pooch. A single duckweed plant is small enough to float comfortably in a thimbleful of water. And yet the sheet into which the dog had gleefully jumped was as large as a city block. So closely were the plants spaced that it was the habit of the ducks, which esteem them highly, to oscillate their partly opened bills and proceed through the spread at half speed, all the time "inhaling" the stuff, with a noise loud enough to remind me of Boy Scouts absorbing soup after a hard day in the field. There must have been many hundreds of thousands of those tiny bits of vegetation in each small patch. There were comparatively few species of plants in the marsh, but the concentration of duckweed and of several other species was great enough to be one of the characteristics of the area.

This impression caused me to consider the distinguishing 
traits of seashore and mountain, other localities of which I am especially fond. The sea provides unlimited vision. The mountain views, though massive, may be considered more restrictive, but the third dimension of depth more than compensates. Both constantly emphasize the forces of nature: the sea by the strength of the gales and the power of the pounding waves, the mountains by the violent thunderstorms, the rush of the streams, the onslaught of avalanches, and the constant working of erosive action. Noise is always present in both situations. Even in calm weather the sea never fails to break with heavy impact on the scree of the beach, and when fully aroused its sounds dominate miles of shore. The rush of the cataracts, the wind in the trees, the movement of the glaciers all vary the noises of the mountain, but the result is not more insistent than that of the sea. Each has its dramatic connotation: the sea with fleets, wrecks, explorations, piracy, history, and adventure; the mountains with grandeur, tragedy, daring, heroism, skill.

The marsh did not fare well in comparison with these heroic aspects. There was nothing three-dimensional about it. If I looked in any direction my vision was soon out of the cattails and into the surrounding business or residence districts. There were lovely views from some points, but they were not a part of the marsh itself. There were no great storms or natural manifestations. The canoehouse manager sometimes refused canoes to novices on blustery, days, but I went out regardless of wind or rain and was troubled neither by storm nor by the swells of canal traffic. There were no ominous warnings of great forces to be released, no preliminary slipping of snow on steep slopes, no sighing of wind which warned the climber to make for shelter. Practically all the marsh noises came from the rustle of trees and smaller growth, or from the birds and mammals which moved about in the locality. There were, to be sure, the sounds of practicing crews and passing boats in the ship canal, and 
many toots and rattles which came from the neighboring activities of man and his machines, but these were incidental to, and not actually a part of, the area. The marsh lacked the majesty of view, the presence of rampant elements, and the roar of their conflict. But its allure was not less than that of the seashore and the mountains. What was there about the marsh to call me back week after week and year after year? I tried to sum it up.

There was the coming and going of the wildlife and its contact with the neighboring human community, which essentially is the theme of this book. There was the opportunity to visit the place frequently, to watch its residents continually, and to get a connected picture of its life and conduct. This, I thought, was not so easy for the man who wished to study the high mountains or seashore. Such locations were many hours away from the city, while the marsh could be reached from my home in four or five minutes. The size and dignity of the larger areas were not to be underestimated, but the lack of space by no means detracted from my interest in the marsh. If I missed the unlimited view, I came closer in contact with the marsh community. In the mountains I knew canyons, lakes, and glaciers, all magnificently impersonal; in the marsh I knew nests and mallard broods and the various preferences of the marsh guests. At the place where I visited the seashore, I watched the surf pile into the creek entrance and batter it with the mass of logs which accompanied the onrush; in the marsh I stopped at the log boom and watched the crows harry a Peale falcon which soon abandoned its original intention to perch on one of the big logs and rest peaceably.

If one place was greater in scope, the other was more vital in its nearness and appeal to the understanding. The noises of the mountain and sea were caused usually by inanimate things; the marsh noises were nearly always those of living creatures, occasionally broken by wind in the undergrowth 
or by small waves. In the proper season I could stop paddling almost any time and locate half a dozen birds by their sounds-some from the air, others in the low growth or in the water. The marsh residents scarcely ever left it except to migrate. If I startled them into flight they went only a short distance and settled down. I seldom failed to spot where they landed and to find them again if I were really interested.

The marsh, then, is an intimate place. There would be little appeal for those who admire the big scene, great movements, and constant excitement. But it is the absence of these things that provides much of the marsh charm. Of what value are two or three hours to the city dweller whose only interest is the mountain or the seashore? Even week ends are too short for trips to such places. But this marsh, so close to my home, fills my two- or three-hour spare periods with relaxation and enjoyment. Indeed, the two-hour rental is the standard time at the canoehouse. Few of the paddlers stay out much longer, partly because of the expense, and partly because they have covered much of the area, and the urge to exercise has been largely satisfied. In two hours I can usually check the birds and the places which I wish to examine. Or I can drift and sunbathe and devote the time entirely to rest. I never have to lean into the wind and wonder whether I have enough time to beat the tide around the points. I am not forced to put all my effort and determination into the ascending of the steep rock gully that leads to the summit of the mountain. I never have to make the descent and return to the valley below, full of enthusiasm for the perfect view and the wonderful trip but equally full of foreboding for the condition of my muscles on the following day.

Fortunate is the man who does not have to choose between the seashore, the mountains, and the marsh. There is no reason why he should not visit them all as his mood directs. But for the man who has little time and perhaps less 
money there is much that the marsh can do. It can say: here are my wild people and the home in which I have put them. Study them, or casually watch them; pry into their habits, their coming and going, their birth and their dying. Visit them regularly, if only for short times. See how their methods and program conform to the nooks and corners in which they live and hunt their food. They nest as soon as, but not before, the proper protective growth conceals the nesting area. The young appear when the food supply suitable for them is most easily obtained. The industry, the loyalty to family, the dexterity of the nest building which, in many cases, is being done for the first time, will surprise you. You will be perplexed by the apparent lack of intelligence which leads them into trouble and the inability with which they meet the situation. You will soon know that, though you are the equivalent of a small-town reporter, a sympathetic and discerning examination of the things you see will be a constant source of knowledge and pleasure.

To those who think that the marsh is flat and formless and without beauty I say that such a thought can be held only by a person not acquainted with it. The marsh is without the vastness and variety of design which marks the mountain and seashore, but beauty cannot be measured in acreage or by complexity. The simple vase and the single rose may attract more admiration and attention than the large and imposing canvas.

It is true that there are not a great many varieties of vegetation to work with in the marsh. In my trips I see few kinds of trees-willows, alders, and cottonwoods. Many small herbaceous plants find a footing. Some of them, such as the mimulus with its yellow monkey-face, the small blue forgetme-nots, yellow mustards, and water celery, are so scattered as to be but tiny decorations on the general design. It is the cattail, the giant bulrush, and the loosestrife which make up 
probably more than ninety per cent of the marsh production. The beauty of the area is due largely to these three plants.

One of the local professors told me of talking with two of his colleagues while they were gazing at the marsh from one of the campus windows. During their conversation he remarked that he had not realized the beauty of that flat and drab-appearing area until he had seen some color movies which had been taken there. Then he was amazed at the loveliness of line, of color, and arrangement.

I think he well described the type of beauty of the marsh. As in other marsh characieristics, understanding comes only with an intimate knowledge of the place. On this day in early August when I paddled slowly along, I looked at a soft, gently waving expanse of green, broken only here and there by the varying greens of cottonwoods, willows, and alders, by still other shades of green of the cattails, and by the large and irregular purple patches of the loosestrife flowers. This is the typical pattern of this time in summer, but it is not as it was six weeks ago and it is different from what it will be at the end of another six weeks.

The general pattern will be little changed but the detail of design will be constantly shifting. The pattern will continue to be one of uniform colors and blocks. There is power in the simplicity of solid color massing which has been widely exploited in the past half century. I observe the result in the planting in the public parks, in homes where gardens have been laid out by modern landscape specialists, in the costuming of the theater and the planning of its scenery. The marsh exemplifies this tendency. In only one other place have I seen much massing of color-in the mountain hemlock forests. But there I notice little contrast through the year, while in the marsh the vegetation changes with such regularity that the advance of the year can be judged by the progression of color.

Three plants-the cattail, loosestrife, and bulrush-produce 
the constant shifts in the marsh color design. The method is really simple: each plant has its distinctive annual cycle, its own structural form, and its own response to the effects of maturity. Each occupies certain definite spots in the area. When the effects produced by each of these three massed plants are combined, they establish the general design of the marsh and are responsible for its pleasing colors and textures.

It is in effect a battle of living colors and textures. The progress is the same each year and can be illustrated by considering one of the three plants. Each spring I see the chocolate-brown framework of last year's loosestrife standing erect and staunch enough so that it becomes the principal framework of the tule wren's nest. The whole marsh pattern then is one of various shades of dull browns. As the new growth begins, it is supported by the stems of the old plants through which it pushes. I watch the plants grow rapidly, their stems branching and growing rapidly each day, the whole plant becoming yellow-green as the leaves open, and its living color gradually submerging the dead tones of the previous season. Eventually the plants attain their full size and crowd the surrounding vegetation. I await the budding in late June, and in early July the whole marsh commences to fill with great blotches of color. Each foot-long spike is crowded with delicate flowers more often of a red or deep rose rather than a purple. In its fullest period the bloom often overshadows the greens. Wherever I paddle I see color-at the other end of the marsh, in the middle distance, and on the bank by my side. The heads, particularly in exposed places, freely show variation in shape and for some reason are often irregular so that they hang stiffly or follow a curving line as if some person had bent them deliberately. In places where the tops of the plants have sagged toward the water, the blooms make a waist-high band of solid color. The show remains at its best for perhaps three weeks. This is the time when I see the few marsh turtles enjoying the hot sun, and when the birds 
have almost ceased singing. The blackberry bushes promise a big crop, for they are full of small green fruit and also carry many blooms. The underwater growth thickens daily. Canoeists grumble over the difficulty of pushing their way through the vegetation which clogs the quieter stretches. The blooming is nearly over by the middle of August. Soon after, the windblown petals cease to purple the channels. The seeds of the loosestrife set, gradually the spikes become stiff and nubby, and the leaves begin to acquire the reddishbrown of early fall. From then on each plant loses its graceful pliancy and assumes a stiffness which it carries through winter.

The progress of the cattails and the bulrushes is similar to that of the loosestrife. They emerge at slightly different periods, each fighting its own battle between the greens and browns, with approximately the same result.

The water-lilies, the yellow pond lilies, the beggar's-ticks, the duckweed, and many other small plants add much to the detail of decoration but little to the general effect. The cattails, the loosestrife, and the bulrushes arrange the pattern.

On this August day I know that the bloom will soon go; the now-green area will be replaced by the changing colors of the maturing plants. The texture will change too as the

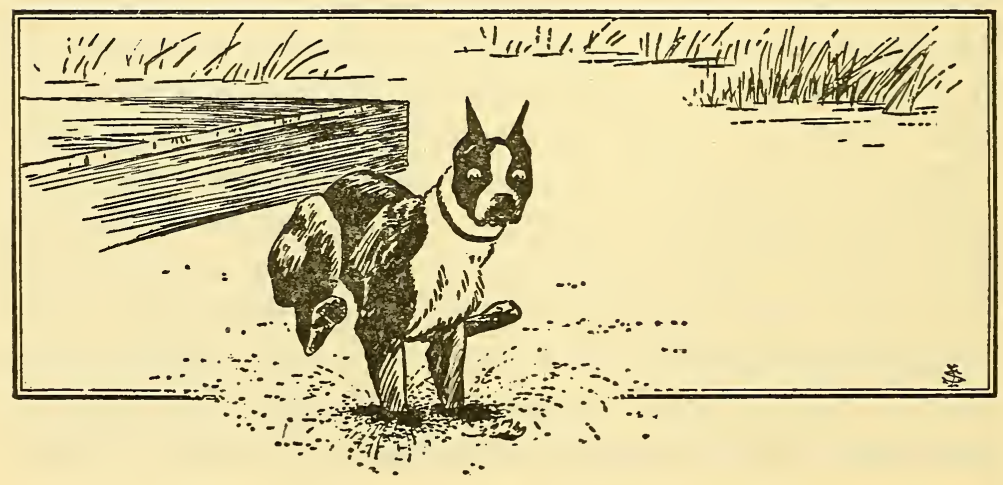


plants slump and their leaves wither. The constant softswaying movement so typical of cattail areas in the summer breeze will cease and only the stiffness of maturity will remain.

The effect of all this convinces me that the program of marsh decoration may be compared to that type of music which emphasizes one specific strain which it plays and replays with endless variations. The theme of the marsh is the gradual change from the browns of winter to the greens of summer and again to the brown of winter. The transitions are simple but they are enriched from end to end: in color by the combination of the countless shades which the plants assume in their annual cycle; and in texture by the alterations in their physical structure as they thrust their new growth through the ground, rise to maturity, and then slip into the decay of late fall. 


\section{Quintet}

\section{9.}

I TURNED MY CANOE TOWARD THE float just as the colored lights on the district advertising signs began to flash. I was tired but well pleased with a trip that had been full of fruitful experience, and delightfully comfortable as well. I had left home after breakfast and had found the marsh free of the early morning fog that frequently invaded it in late September. The air had been clear all day. In the morning the Cascades were flat and dark but the climbing sun illuminated the few valleys and ridges which I could see in the Olympics; in the afternoon conditions reversed so that it was the Cascades that stood bright and warm in the sunshine while the shadows darkened the flanks of the Olympics. Coolness marked the early morning, a light breeze followed until the sun passed the zenith and brought an afternoon full of warmth and ease.

I had planned to search, not for mammals, but for those slow and elusive marsh birds known as rails. They seemed to lose some of their characteristic shyness in fall, and I wanted to check them over and confirm my belief that a bird that I had seen the year before, and which I thought was too big to be either a sora or Virginia rail, might prove to be a clap- 


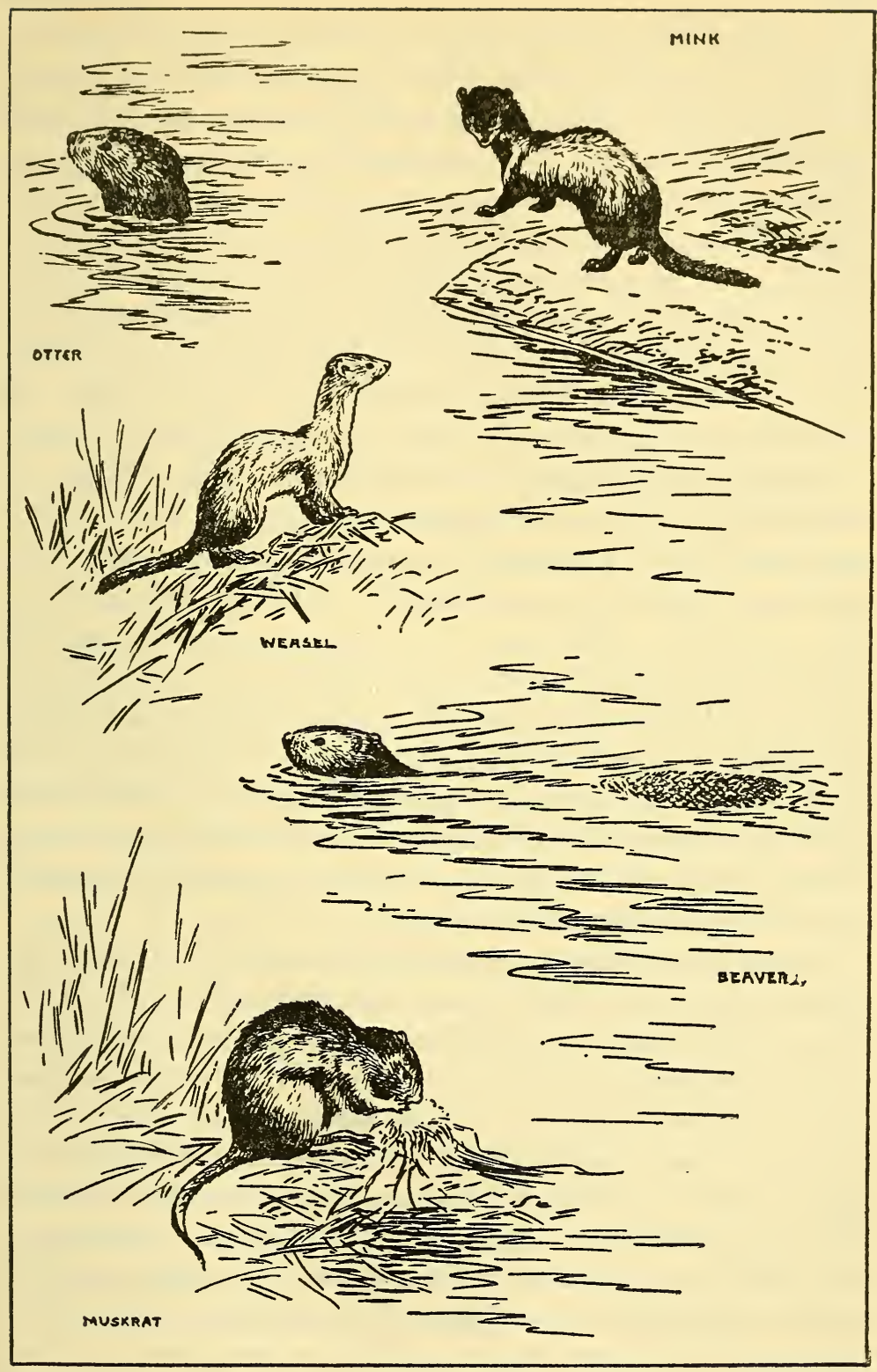


per rail, a bird which had never been recorded from the marsh. I carefully followed the margins where I had previously seen rails-tangles of cattails and rushes with thin open spaces between them, and wet muddy ground on which the birds could walk. The sora-brown, compact, and with a short bill which gave it the popular name of chicken railstood on a $\log$ and kindly allowed me the opportunity to watch it preen, a rather elaborate proceeding which required at least twenty minutes. The Virginia rail clattered loudly from the rushes and two or three times slipped back and forth from one point to the other in the foreground. It was a surprisingly good day for rails, but although I carefully watched every movement in the vegetation no out-size bird appeared. Twice I covered the marsh without success. I ate my lunch at the very spot where the bird had flashed by me the year before. All I saw was a song sparrow as it slipped among the cattails. Even though I failed to find a clapper rail I was more than compensated in other respects. Something about the day, perhaps its early crispness, or the odor of the dew-covered vegetation as the sun struck it, or the harsh freshness of the still and black water, or possibly just a strong craving for food, seemed to stimulate the marsh mammals and to bring them into the open.

It was a good day for mammals. Not that I was ever surprised when I saw them. I had seen them often before: the beaver a few times a month, the muskrat perhaps every other trip, the weasel at rare intervals, the otter a few times a year, and the mink irregularly and in no particular season. But they were not common and the odds were tremendously against meeting many of them in a twenty-four-hour stretch. This day proved most rewarding so that when I went home I felt like a man who had held four aces at an opportune time in draw poker or like the golfer who had at last made a holein-one.

During the day I thought much about these mammals 
which were common to the marsh. This quintet-otter, mink, muskrat, weasel, and beaver-are all competitors to a degree. They have fields of activities, each of which might be represented by segments of the area of a circle. If these circles were laid down so that spaces representing similar activities would intersect, it would be found that each animal would have areas in common with those of others. It would also have space which did not conflict with the other four. For example, I am sure that the members of the quintet, except for the beaver, would and did include frogs in their diet. Perhaps all ate some vegetation, although there would be a vast difference in the proportion consumed by muskrat and weasel. Fish were of prime importance only for the otter and mink, cattails and rushes interested the muskrat and beaver, while the only considerable user of tree products was the beaver.

As I made my rounds I was particularly struck by these differences. My slow and quiet paddling brought me almost up to a muskrat, known by almost everybody as a semiaquatic mammal, three or four times as large as a rat, but thickset, and with a tail laterally compressed to facilitate swimming. It was busy in a way common to no others of the quintet. It stood, surrounded by water, on a little platform of cattails. Much feeding had been done in the vicinity, for the cattails had been cut close to their bases. From its raised dais the muskrat could watch and move quickly into the water where its speed and skill could be used to the greatest advantage. It needs its skill for it has many enemies and, without question, only the number and size of its litters have enabled it to withstand the heavy pressure of predation. The area is trapped every year, and filling constantly decreases its size. Hawks, owls, and mink regard muskrats highly.

Muskrats are especially vulnerable when the water is low for they have neither speed for flight nor ability in combat. Inasmuch as they are often a nuisance to cultivated places 
they face the additional danger of trapping by owners who wish to protect their property.

I found the muskrats well scattered over the marsh. They live in two ways: in bank burrows reached by underwater passages, and in above-ground houses somewhat similar in appearance to beaver lodges but much smaller and built of lighter material. Formerly I saw a dozen of these houses around the marsh, but for some reason few are now built. I do not think that it indicates a decided drop in population, but probably is due to some cause such as a change in the water level or the greater protection offered by a bank burrow. These burrows cannot be reached from above and therefore must provide better protection from dogs or other mammals. The muskrat has never appeared to me as fast a swimmer as a mink. This may be due to the fact that, as a predator, the mink has need of greater speed and strength and has therefore developed in that direction.

I passed three muskrats at different times of the day. They swam quietly and easily, their passage marked by a small $\mathrm{V}$ at the rear of the partially exposed head. When I made no change in my tempo and refrained from noise, one of them kept on its course and passed close to me, but when I tapped the canoe lightly it immediately dived and I saw it no more. The other two swam to the bank and then went underwater, evidently into their burrow entrance.

They are considered to be almost nocturnal in their habits, but $I$ have seen them now and then in the middle of the day and very frequently before the sun has risen high in the morning. On this trip I saw their droppings on little points of projecting earth where they seem to make a practice of leaving them. I saw empty shells on similar exposed bumps and I assumed that they brought them there for food. I have been told that they leave fresh mussels in the sun until they open, but this is only hearsay. I have never seen any evidence of food storage and wondered why until I was in- 
formed that they do not collect supplies for winter use. Winter life must be comparatively easy in the marsh, for the ice seldom gets more than two or three inches thick and then only for a short time. It is therefore easy for the local mammals to get about and feed on the crustaceans, the freshwater mussels, and other bottom dwellers. But where shallow ponds freeze to their bottoms the hazards must be greatly increased and the mortality heavy. I have always thought it strange that "marsh rabbit," which is sold freely in some sections of the East, has never been popular as a food in the West. The muskrat's habits are clean, its food better than that eaten by the average chicken, and I cannot see why it should not be as good or better than rabbit-but I have not yet tried it.

The fur of this animal is soft, light, and strong, and is sold under a number of trade names given it by the furriers. The yield of marshes is so imposing and the number of skins taken so great that the muskrat is the most important of the North American fur mammals. Everywhere in the United States and in many other countries the muskrat is exploited by professional trappers, by farm boys in their spare hours, and by part-time amateurs who find it an easy way of earning a little extra money. Commercial exploitation goes on in the marsh each year. When trapped too closely a location is abandoned because it is no longer profitable. When this happens rehabilitation usually begins at once, and a few years of rest will find the area fairly well populated again.

I consider the muskrat, the first of this quintet, a creature of peaceful disposition, doing practically no mammal predation, living largely upon aquatic vegetation of little economic value and, except for its occasional piercing of earth dams and irrigating banks, doing very little damage to its neighbors. It lives within the marsh boundaries, takes its living from the marsh community, and seldom leaves the area except to go to one of like characteristics. I suspect that most 
muskrats in the marsh die a violent death, some at the hands of trappers, others from the attacks of owls, dogs, hawks, and minks. It is almost a law of such communities that the animal which takes its living there shall, at some early or late time, furnish its own carcass as food to the inhabitants of the same area.

The mink which I saw that morning stood on a log raft and looked at me, if a mink can so look, with a mixture of curiosity and insolence. It loped to the back of the raft, then ran along parallel to the progress of the canoe, stopping only when it reached the last boom stick. Its wariness either is sometimes suspended or is overcome by its inquisitiveness, for often I have let my canoe drift toward it until I could have touched it with my paddle. It did not move until I had to back-water to prevent hitting the shore or a log. Only then would it turn and walk away. It is a member of the weasel family and has many of the weasel habits and much of its structure. It is long, slim, and short-legged. Its habits overlap with those of the muskrat in that both of them eat frogs, clams, shellfish, and some vegetation as well. But from there on the habits of the two mammals are quite different. I think that it lacks the top swimming ability of the otter, although I have always regarded the mink as a master of its craft. It probably spends more time on the shores and margins of the streams than in the stream itself. That does not mean that it is not at home there, for it is an excellent fisherman, a hunter of aquatic birds and mammals, and an especial enemy of muskrats which it is able to follow into the depths of their burrows. I have always wondered to what extent the brown rats in the nearby sanitary fill are used for food by the mink, and whether the presence of rats reduces the pressure on the muskrat. Mink are known everywhere as excellent ratters, and many descriptions have been written of the daring and skill of the attack. The battle, which is said to be very 
short, ends with a grip on the head or neck of the victim and results in immediate death.

Mink, like the rest of the weasel family, have strong scent glands which they use freely when angry or frightened. That the odor is unmistakable and unpleasant is indicated by frequent reference to that of the skunk. Some have called it the worst of the two, a comparison which requires proof.

The habits of mink are not all bad. They eat live and dead birds, wounded waterfowl, fish, rats, mice, and other small mammals. There is some disagreement regarding the economic status of this mammal, but some authorities hold that its destruction of farm pests and smaller predators accomplishes good far in excess of harm. I am afraid that most farmers would contest this statement as few agriculturists have any use for any members of the weasel family. Its life in the marsh probably does not often end as a feast for other predators because in the city there are few that might be a match for it. It is quite possible that, in the wild, the wolf, coyote, and other large carnivores are able to catch it unawares and finish it without even offering it a chance of battle.

One mammal in the marsh does interfere with the normal interrelationship. Man, the predator, hunts yearly for the mink. Its fur is fine, soft, durable, rich, and much coveted by women of means. One mink usually surpasses several muskrats in value, and so, during the trapping season, the marsh harbors traps which take a few of the animals.

The mink is historically noted as the first mammal to be raised in captivity for its fur, a business which I thought was probably thirty years old but which, I found to my astonishment, was tried over one hundred years ago. The venture has been a success, the proportion of pelts sold from animals in captivity continually increases, and many furriers claim that eventually fur farms will be the principal source of mink fur. The number of mink is determined by economic rather 
than natural controls. As the price of the fur goes up, trapping increases and the supply diminishes. When prices go down, trapping is less extensively followed and the number increases.

The mink, second of the quintet, then, is not a vegetarian like the muskrat but obtains the greater part of its living as a predator-as a hunter of birds, fish, and small mammals, and as a consumer of dead fish which happen to come its way. The marsh economic status of the mink is largely based upon its choice of food: the proportion of the beneficial to the injurious creatures which it consumes. A diet of waterfowl would be regarded as harmful, but if the brown rat, is its principal food, the mink might be considered a beneficial factor in the marsh.

When I left the area where I had seen the mink I was in somewhat of a quandary. I had passed the best time of the day looking for rails. If they came out of the marsh at all, it was when the shadows were heavy enough to limit visibility, and there was plenty of protective darkness in the nearby tangle of cattails. I thought it useless to look for more mammals. I scarcely ever saw more than one a day, and this morning I had already seen two. It was too much to expect to do better.

I started toward the canoehouse but did not get far. I stopped because I could think of no better place to spend the rest of the day. It was the time of year when the gulls had begun to gather on the log boom, when fat mallard hens drowsed in the sun, and the tule wrens recalled bits of their spring songs. The temperature exactly suited me. The water of the bay had lost its summer murkiness. The cottonwoods were feeling the approach of fall so that now and then a leaf dropped into the water.

I let the canoe drift across the bay and paddled into the cove. There I decided that this was my lucky day. A noise 
on the west side of the canoe attracted my attention and I turned as two brown shapes appeared at the surface. They looked about, showing no alarm at the nearness of the canoe, then dived again. In previous visits I had seen them come up with frogs, but this pair might have been playing for they dived repeatedly and emerged with empty mouths. They moved about in their typical otter manner, diving, sometimes appearing close together, and then widely separated. After a short time they headed toward the open bay and I lost sight of them.

I considered the position in the marsh of this third member of the quintet-the otter. It was friendly to such locations and a regular but temporary visitor. When the timber remained around the lake and men were not plentiful, these mammals had probably lived and raised their young in the area. They were never numerous like the muskrats. They are great wanderers and often make regular tours after the breeding season. Their food includes such items as shellfish, crustaceans, some vegetation, and frogs, but their principal diet is fish, and in that field they are competitive only with the mink. Their long, contoured bodies are well suited to animals whose land habits are only incidental to their water existence. They are the most efficient of our marsh swimming mammals, well equipped to make their way upstream through the fastest of white water. They lack the ferocity of the weasel and mink and make intelligent and interesting pets. Although I have seen many of their slides, I have never seen the animals play on them. For many years no other creature attracted me like the otter. This was because I had read a book, Tarka, the Otter, written by an Englishman named Williamson, a writer who has most effectively portrayed the life of a wild animal. It made me realize that fair play is one of the great necessities of a conservation program.

At present the otter makes such short stays that it has little effect on the marsh situation. It has had a small part in 
the disappearance of the bullfrog. At one time the bullfrog's voice was heard as regularly as the automobile horns at some village intersection, but now it is almost silent. Certainly the otters like them, for nearly every time I have seen them they were fishing for and catching bullfrogs in the shallow, rushfilled water of the west margin.

Naturally solitary and never present in great numbers, the otters are not plentiful in the state of Washington. Trapping disposes of many of them during the season, and as the fur, though heavy, is rich and durable, the pressure will unquestionably increase rather than diminish. In the marsh there is no probability that they will again be permanent. Their competition with other marsh animals can be regarded as negligible.

In terms of baseball my batting average remained high. My next hit came unexpectedly: after passing a short stretch and rounding a small bend, I caught sight of a weasel standing on a bank. Movement frightens some animals and they immediately dart away. But I think that it was the movement of the canoe that attracted and held the weasel. It must have stopped short while it was crossing a low branch, for its head was erect, its small forefeet were on the wood, and its rear feet were still on the ground. The creature was handsome, graceful, sinuous, with tannish-brown back and yellow underparts. Small head, white throat, and bright beạdy eyes gave it a somewhat sinister appearance.

Except that it is not a regular eater of fish, the weasel might be described as a smaller edition of a mink, equally efficient, active, and bold. I am quite sure that it does not enter the water regularly, although in the marsh $I$ have seen it most often close to the water in the growth along the banks and on sticks and logs. I have met it less than the other members of the quintet, but the canoehouse manager sees it much oftener than he does the mink. When a weasel hunts around 
the canoehouse for mice and rats, the two dogs bark and attract the owner's attention.

Accounted the most bloodthirsty of the local mammals, it has few traits which appeal to people. It is a killer of mice and birds, with the former probably furnishing the greatest number of victims. Powerful neck and shoulders, long sharp teeth, quickness, and courage make the weasel able and willing to tackle and vanquish any prey which it meets. I have not seen it kill in the marsh, but the cries of terrified creatures in the mountain rock slides, and the appearance of a weasel soon afterward, have taught me much of its power and domination over animals, which sometimes exceed it in size. Authorities have estimated that the weasel eats over twice its weight a week. If a man consumed a comparable poundage in lamb chops, he would have to be as busy as this slim, tireless, and fearless creature because, at present prices, it would require between two and three hundred dollars a week to pay the butcher, a formidable job even at overtime rates. There seems to be some evidence that the weasel stores some food for future requirements. A few burrows, when opened for examination, have been found to contain unconsumed small rodents.

I have always suspected that the weasel has more enemies than the mink. Its smaller size brings it within the predatory capabilities of many more birds and mammals. It is probably a regular part of the food of the mink. Its position in the food chain is intermediate.

Here in the marsh the habits of this creature cannot be said to be especially harmful. Although it lives by predation there are no poultry yards to be raided, and the greater part of its activities are probably directed toward the smaller rodents which far outnumber its other possible prey. Its competition with the rest of the quintet may be assumed to be small, for it does not take the larger birds attacked by the mink and seldom enters the water for prey. Locally, it there- 
fore fills a unique and perhaps beneficial place. The hate heaped upon the weasel is not always justified, and I have thought it largely due to the charge-which is sometimes true-that it kills far more than it can use.

The manager, raised on a farm where he had witnessed the ferocity of the weasel when the animal was loose in a henhouse, has a quite definite opinion of it. When we saw one standing on the bank, he said:

"That fellow's going to have a short life if it keeps fooling around here."

"You haven't much love for weasels," I said.

Unsmiling, he replied:

"I don't concern myself with them when they are just traveling. But when they begin using the birds around here for their meal ticket, then it's different."

"Do you keep them cleaned up?"

"The dogs do a pretty good job, but once in awhile an animal starts hanging around," he said. "Then I make it my business. I'm not going to have a weasel staying and bothering the young birds that feed at the float and live around here."

"Do you think there are many?" I asked.

"If there was only one, it would be too many as far as I'm concerned. All farmers feel the same way. They look after and feed the birds and they don't like to have the young disappearing one by one until they are all gone. Theý size up the weasel as a plain murderer and they take steps to stop it. A man's got a perfect right to protect himself against such vermin."

Incidentally, the manager thinks that weasels are easily eliminated. The cat is not the only animal that becomes the victim of curiosity. A weasel may make a terrific dash for shelter, but before retiring permanently it frequently steps out for a look-see. This habit is often its undoing. 
The rest of the afternoon passed uneventfully. A banana and a sandwich remaining from noon made a scanty supper. I drifted, slept a little, and moved from place to place as the impulse came to me. Exploring was over for the day. I left the east end of the bay where the wind had blown me and paddled toward the canoehouse. Boats which had been out on Pudget Sound passed through the canal on their way back to their moorings. The gulls had left the log boom and were slowly flying to their roosting grounds. I heard the sound of a distant fog horn; mist or smoke had begun to settle in some pockets on salt water. The marsh smell had replaced the sweetness of the summer odors. I passed the outer islands and into the channel which led to the canoehouse. I had enjoyed the long day but was beginning to be glad that it was over. I removed my field glasses and put them in their case just as I saw movement in the water. The slap of my paddle was a bit loud and was followed by the slap of the animal's tail as it went under water. I could scarcely believe my good fortune at first. It was a beaver. I had batted one thousand. My score had been perfect. For the first, and probably for the last time, I had broken all the laws of probability and had seen in one day every member of the marsh quintet. 


\section{Pigskins and Dowitchers}

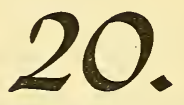

I THINK THAT NOBODY CAN GAINsay this: the life of a city is certainly different from that of a marsh, so much different that the existence of one is not compatible with the existence of the other. But sometimes the two are found continuing, temporarily at least, in a sort of balance which grows progressively less in favor of the marsh and progressively more in favor of the city. Often there is a remarkable amount of adaptability on the part of the marsh dwellers so that with half a chance they manage to exist and even to prosper. This is the story of one of the days in the area when the impact of the human crowd seemed almost overwhelming. It began this way. I walked down to the canoehouse one September morning with the feeling that fall was very near. The wall of the big athletic pavilion was free of the many cliff swallows which yearly daubed their clay nests in the high window recesses. They had flown late in August. The barn swallows which nested freely in small buildings and tunnels around the stadium had either left or were with the birds which had congregated in the marsh preparatory to migrating. All the haziness caused by summer forest fires had disappeared, and the Cascades, tipped by 


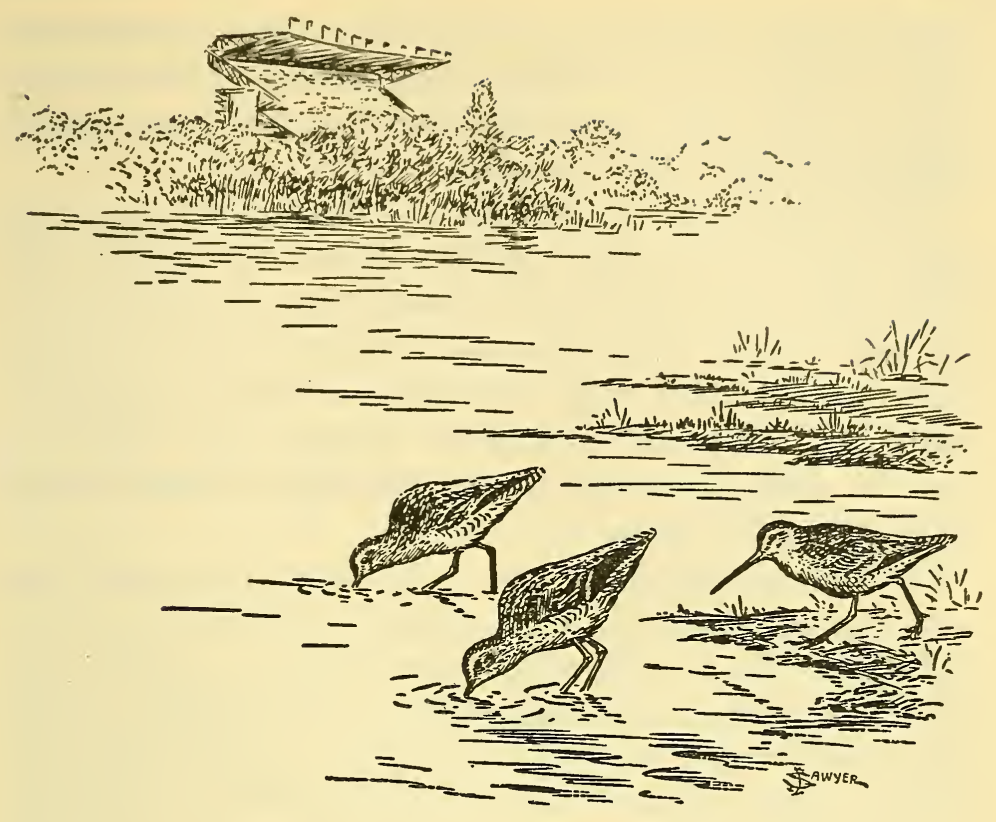

early snow, revealed an undefiled beauty which only such storms can bring.

If the departure of some birds indicated the passing of summer, the arrival of others announced the beginning of fall. Hundreds of gulls crowded the baseball field on the north side of the road. They had been away for several months to their breeding grounds but now they were back, some only temporarily before they went farther south and others for the entire season. A dozen killdeers ran up and down the outfield and uttered their silly cries in what was apparently an attempt to excite the other birds. The gulls simply remained in one spot and followed my progress by turning their heads, and in the meantime gaped with wideopen bills or stretched their wings as a newly awakened man might stretch his arms. The colors of their bills varied from flesh to yellowish-green, their mantles were of different 
shades of gray, and their legs of pinkish, yellow, or yellowishgreen, which told me that all of our common gulls-the herring, the short-billed, the ring-billed, the California, and the glaucous-winged-were present.

If this had been a practice day for the football squad, the space back of the athletic pavilion and to the south of the road would have offered more proof that fall had come, for this was the spot where the team prepared for the season, where two hundred of the University's brawniest gathered and submitted to the formidable training that would put them in condition to qualify as defenders of the football honor of the University.

I had often stopped to watch while they practiced. They went through bending exercises, they lay flat on their backs and did the bicycle, they sprinted madly up and down the field, they passed and kicked the ball. They shifted and signaled and plunged from formations. The coach, megaphone in hand, observed everything from a small tower, and whenever necessary gave instructions which were put into effect by the assistant coaches on the field. Although the men were soft and out of condition at the beginning, the practice proceeded rapidly. No time of year was tougher for a football squad, but for the gulls in the field no time was easier. Their young had long been able to shift for themselves. The mature birds could sleep the day out, if they chose, in the mild sun. The complete immobility of the whole flock showed its total relaxation.

I had seen no such relaxation among the coaches and players. Football was a sport for the multitude, but for the participants it was grim business where wisecracks and friendly smiles seemed to have no place. From among the candidates would be selected the fourscore men who would make up the regular squad to represent the University during the football season. From thirty to sixty thousand people would see each of the games. A million more would hear the 
radio accounts and would rejoice at the team's success and feel free to criticize it and the coaches for the losses. Fame would come to the regulars; obscurity and drudgery would be the lot of the reserves. There may have been light-heartedness and humor in the showers, but I saw none on the field. The man who fumbled the ball or failed to follow instructions showed by his actions in the next trial that he realized the enormity of his crime and was determined not to repeat it. There was no letdown. Men who apparently had been overlooked by the coaches gathered in little groups and busied themselves at practicing starts or passing the ball. When I left I had never failed to contrast the two sides of the road, the gulls so indifferent to the problems of living, and the men so intensely absorbed with the intricacies of sport.

On this day the practice field was deserted. It was easy to tell why. The popcorn and candy trucks parked in advantageous situations, the student guards placed at intervals to prevent cars from blocking vital lanes, the sight of boys wandering about the stadium fence, and of men going in and out of the gates clearly indicated that a game would be played in the afternoon.

At the canoehouse a sturdy black-headed lad of about twelve watched me as I worked.

"What you doing, mister?" he asked.

"I'm getting ready to go out in a canoe."

"You going to be out long?"

"Four or five hours, I expect."

"How much do they charge?"

I told him the hourly rate. He looked at me incredulously. "Gosh, mister. You could see the game for that. You could get a good seat, too."

As I pushed off I knew just how a boy of that age felt. Why did a man who could go to a football game want to do anything else? Nothing should keep him away. Nothing could keep him away from so desirable an event. He reminded me 
of the boy William in the play, The Return of Peter Grimm. The boy rushed into the room carrying the two circus tickets which Peter had asked him to get. He refused to believe the doctor's statement that Peter was dead, and he cried out: "He can't be dead, I've got his ticket to the circus."

Out in the canoe I found that it was a dancing day. Multitudes of small insects dipped almost to the water surface and then rose a foot or so to repeat the movement. The rhythmic flight entirely surrounded me and may have covered the entire marsh. Then came dime-sized moths which flew, not with the graceful rise and fall of the first performers, but clumsily and abruptly. I could hear the faint buzz of their wings if they were near the canoe. This abundance of food was not long overlooked: a pair of sparrows hopped along a floating log and skillfully picked off the insects that came within range. The barn swallows which had been assembling in the marsh appeared in great numbers, the birds of the year distinguishing themselves by the awkwardness of their flight and the clumsiness of their hunting. Many thousands of insects must have been taken but thousands more still danced in abundance.

I found that it was to be a day of activity everywhere. Practice planes from some aviation school droned back and forth at uncomfortably low levels. The noise of a loud speaker came from the stadium-the half-completed sentences indicated that they were testing the system. Somewhere on the campus the assembled band practiced the promising strains of "Roll Out the Barrel." Workmen walked about the stadium and gave the preparations a final look. The great structure stood cold and lonesome, but I knew that shortly it would be vitalized by the bright colors of the crowd.

The fact that the stadium would soon be full of moving, cheering people did not affect the activity in the marsh. The blackbirds, which always used the big cottonwood trees at the north end for their fall gathering, chattered and flew 
about in mass movements, then returned to the tree with chattering undiminished. Two bitterns left the ground to which they ordinarily confined themselves and made a couple of slow flights over the cattails. The chickadees and song sparrows sang disjointed portions of their spring songs. Something about the day stirred the marsh life into pleasant movement. Only the mallard with her convoy of young that I had seen the week before was absent. I looked for her constantly as I paddled along. If cups and trophies had been presented in the marsh, she would have been entitled to the grand prize, for she had brought out the latest brood of young mallards that I had ever seen or could check in the local records. I was anxious to find out how such a late hatching would progress.

I heard the clear and thin keek of one of our regular fall visitors and soon found the bird on a mud flat. It was a longbilled dowitcher, a brownish-colored shorebird, a little larger than a robin, plump bodied, moderately long-legged, with a habit of feeding in soft ground. There it probes with a bill which has the advantage not only of length but of a set of sensitive nerve centers which instantly determine the character of things it touches. As I moved closer it uttered a little gurgling cry which I had long since learned was a note of alarm or uneasiness. Most birds would have flown, but not this one. Webster's dictionary has described the dowitcher as the tamest and most easily killed of the larger snipe. It significantly adds: "They are fast being exterminated." The name dowitcher is supposed to have been derived from the Indian $t a$-wish or $t a$-wis. If this is true the present word may have evolved from the adding of an er and a change in spelling. But like many other names the origin is obscure and another ornithologist has suggested that the name resembles the bird's call. Elliott Coues associated the word with "Dutch" or "German" snipe. I had never seen just one dowitcher before. They usually appeared in the marsh in groups 
of from three to six. I thought that its being alone might account for its restlessness, for it did not feed and it finally crossed to an exposed piece of land. It would not go far and I could look it up later.

I paddled into the bay to search for the mallard hen and her ducklings while I watched the incoming people. The floor of the field was not visible, but I was at the open end where I could see all the upper seats and the gay flags of the colleges. The gates were still closed and only a few men, evidently in charge of ushers, moved back and forth. Cars were beginning to park, with considerable noise of engines and of brakes which, strangely enough, reminded me of the spring chorus of frogs-their shrill tones softened and blended by the distance. Motorcycle police patrolled the highway and directed traffic. Thirty thousand people must be taken care of before two in the afternoon, so it was necessary to put the first arrivals in places that would set a pattern for, and facilitate, parking during the rush.

My canoe had drifted against a log which seemed a good place to tie to. The situation afforded a fine view of the stadium, the slope leading up to the campus, and the University buildings. Between the stadium and the campus stretched the road which brought the fans to the game. A thin string of people trickled along the path which crossed over a viaduct to the field. Through my binoculars I noticed that many of the women wore yellow chrysanthemums and that some of the men carried robes, pennants, and pillows. Along the highway the cars turned in, backed and parked under the eyes of attendants, then unloaded their passengers for the walk to the gates. Football is a grand game, but what a complex affair it has become: million-dollar stadiums, annual gate receipts that run into big fractions of a million, strings of coaches, assistant coaches, trainers and rubbers, and scores of players-all are an accepted part of the game. A long road had been traveled since the time when two sides 
chose up and kicked a ball about the commons. The trend is more toward making it a great city spectacle rather than a friendly competitive sport.

But I had only to focus my eyes on the immediate foreground to forget the confusion and excitement and imagine myself in some country marsh. The black water and the cattails which lined the shore were exactly as I would have seen them far from town, and the smell was like that of the country, varying with the rising or dropping of the breeze and as distinctive as the smell of sagebrush after a shower. The little waves that struck the boat seemed to push back the feeling that I was in the city, and the many minnows which moved through the floating pondweed recalled quiet reaches in some isolated lake. A dragonfly hovered about, then dropped down and landed on my knee where it rested motionless until, with a swift maneuver, it shot up a distance of two feet, captured a flying mosquito, and as rapidly returned to my knee. This happened twice and each time I thought that I heard a click as it attacked, but I may have been mistaken. I observed the insect closely while it remained motionless, blue-green and with black bands on back and with dark knobby head. Then it flew away.

For the rest of the day I divided my attention between wildlife and sports. The stadium gates opened and the tunnel entrances spewed their contents so that, in almost no time, the nonreserved seats were filled. Then the tunnels of the reserved sections began to discharge a slow stream of spectators who had no need to hurry but came early to see the preliminaries. I heard the shrill cry of a crow just as a Cooper hawk dropped into a cottonwood where the bird was sitting, almost at the edge of the stadium field. The crow showed its anger by calling and by hopping from branch to branch above and to the side of the intruder. The hawk sat motionless as if too proud to pay attention to the indignant protests. When the crow finally left, it first hopped to the top 
of the tree, and I wondered if it was because it was afraid to give the hawk an opportunity to attack from above. The hawk remained indifferent. I had seen it in the marsh before, and I think it fed on the chickadees and smaller birds. It played its own game, one more deadly than the one which soon began.

It was nearly one-thirty. A gaily colored moving strip of people had replaced the thin line crossing the viaduct, and a wide band crowded along the highway from the unloading cars. Horn blowing never ceased. Paper and program boys shouted. A continuous procession of buses discharged their loads at the rear of the stadium. The tunnel entrances poured out crowds faster than the ushers could seat them. The roofs of the small buildings became covered with students who sprawled and smoked while they waited. The public address system announced the scores of eastern games and the spectators cheered the victories of their favorites. Now the band began. It was a skillfully executed build-up, with the tempo gradually increasing and the crowd becoming more tense and expectant. The announcement of the teams and their starting line-ups came to me clearly. At last, the hush for the national anthem, a great roar as the ball was kicked, and the game was on.

I had seen three fair-sized shorebirds with white on their backs fly and land on a small flat between me and the stadium. What could be nicer than to anchor there and do a little photographing while I listened to the game? I was glad to find that the birds were dowitchers. They stood in water three inches deep and busily probed as if they found the results satisfactory. My approach brought out a series of alarm notes, but I moved slowly and carefully and succeeded in grounding the canoe without flushing them. Cheers from the field indicated that some spectacular play had been made by the home team, but the noise of the low-flying planes prevented me from hearing what had occurred. 
The game went on, the cheering continued, the bands played, the planes circled continually, the sun appeared and reappeared from under thin clouds while three birds from northern Alaska fed within two blocks of the stadium. Now that the canoe was still and they were accustomed to my presence, they showed no concern at the click of the camera, the winding of the spring, or my movements. I was curious to know whether they had been near to man or other predators. Such unconcern appeared unnatural even in these, the friendliest of shorebirds. Food was not much of a problem for them. The depth at which they fed removed all competition: most of the shorebirds which visited the marsh lacked length of bill, and only the Wilson snipe could reach the layers where the dowitchers probed. In how many marshes had they fed between here and the Alaska area where their kind courted, mated, and nested? In how many marshes would they feed between here and their winter range which reached from our southern states into Central America and as far south as Ecuador?

I learned from the public address system and the cheering that our team was not doing well. The rooters frantically implored the players to "hold that line," a request which was ignored, for just before the end of the first half the visitors scored. This was a decided upset, as the odds were much against them, and the sports writers had predicted a victory for the home team. The half ended with the score, 7-0. I could not see the field but I knew the routine that followed at half time: the striking card displays, the drill of the college band, and a few comic stunts. The crowd roared its approval and the period passed quickly.

My guests evinced no interest and fed steadily, stopping only once when some low-flying gulls passed. They might have thought them hawks, for they cried excitedly before resuming their probing. After awhile they seemed less hungry, their industry dwindled, and then they abruptly prepared to 
sleep. They stood close to shore, the water just touching their feet; they placed their long bills under their wings, raised one leg, and stood with eyes nearly closed. The terrific roar which accompanied the second-half kickoff did not open a single eye.

Two of the planes had left the area so that I could now hear the announcer almost continually. The home team began to do better: the chant of the rooters changed from "hold 'em" to "touchdown" and before much time had elapsed a touchdown had been made and the extra point kicked with a resultant 7-7 score.

There was no sportsmanship in the dowitchers. They ignored the game and continued their nap, the light wind stirring their feathers, and their bodies swaying easily on one leg. Had they been standing on both they would have been subjected to constant strain. Now and then their nearly closed eyes opened wide, then were almost immediately shut again. I struck the canoe sides with my open hands to note their reactions-they awoke with a little jump that moved them a few inches, glanced about, closed their eyes, and resumed their sleeping. I next struck the side sharply with the end of the paddle-they shivered violently but did not move. Quite evidently they had no fear of me. Such trustfulness would make them easy prey for a mink or fox. Possibly they had come a long distance and needed sleep badly.

I must confess that a nap seemed like a good idea. I closed my eyes and stretched out on the pillows. But I could not let myself go. I wanted to watch the guests and hear the progress of the game. I sat up and went back to my business. The birds still slept, the game dragged, the desire for a nap returned, but only for a moment. Then I glanced to the south and saw a number of tiny white triangles floating on the water and bearing down on me. I wished that some of the fairy-loving children of my friends might have been here, for it was a fleet of feather galleons from the moult of some 
marsh mallard. Each was composed of a single feather whose lower third rested on the water and whose upper part curled upward to make as proud a sail as might have been seen on a Spanish caravel. A hundred, possibly more, with wind in their sails, bobbed and progressed in compact formation until they passed the canoe and disappeared far down the bay. The little people themselves could not have fashioned a more lovely and impressive flotilla.

The fortunes of the game moved back and forth with the home team showing a slight superiority, but facing the necessity of again scoring if they were to avoid a tie. The position was desperate-were they to start the season with a virtual defeat by the smallest college in the conference? The answer came in the last two minutes of play. A touchdown and a successful try-for-point put the visitors at the short end of a 14-7 score and the half was soon over. From the standpoint of the spectators it had all the elements of a perfect contest. No novel of action could have been better constructed: great promise at the beginning, conflict, temporary defeat, misfortune almost assured, then the sudden reversal, and the happy ending. The crowd listened to the playing of the alma mater and went out contented.

The afternoon was over for them but not for me. I was looking into the private chambers of my bird guests. I had watched them feed and slumber. Now I saw them in all the intimacy of their toilet preparation. Two of them had finished their bath, and while the third still slept they began the exacting task of caring for their plumage. The process spoke much for the advantages and economy of simplicity. First came a series of shakings of the entire body until every surplus drop of water was thrown off-an excellent substitute for a large Turkish towel. A preliminary adjustment of the feathers followed. Most important of all was the application of a special kind of toilet and waterproofing oil long known as a reliable preparation for imparting that sleek and 
shiny look to the appearance. This oil did not come from an overpriced and elaborately shaped container but from the bird's own traveling kit-oil sacs located in its back and just in front of the base of the tail. The long bill dipped into this container and then applied the substance bit by bit until every feather in the plumage had been properly treated. Many careful rubbings and feather adjustments accompanied the applications so that, before the task was completed, the inevitable confusion that accompanies the break-up of a football game was over and the traffic was almost normal.

But I was in no hurry. I wanted to see the finish of this careful routine which required as much attention as the headdress of an actress but which served so different a purpose. The toilet of the human female is primarily for beauty while that of the dowitchers is essentially for utility and is as important for the male as for the female. The necessity for proper care of the bird's plumage cannot be overlooked. Anything that interferes with its functioning may have serious results. Flight depends upon the condition of the feathers and warmth is maintained by the insulating effect of the plumage and of the air cells which are created. The many fuel-oil-soaked birds that I have seen dying upon the beaches have taught me that the bunching of sticky feathers absolutely removes this insulation. Without this protection the birds are exposed to the weather with the same consequences that are suffered by a man who has been robbed of his clothes and left to wander in a winter storm. The birds in some manner must have known how necessary this treatment is to survival, for the whole ceremony was performed with the utmost deliberation and care. Every small area was reached by the oil-applying bill and every part was smoothed carefully. Then followed the final polish when the head moved about rapidly and the long bill flew here and there like a fencer's sword with such seeming recklessness that it seemed certain that damage would be done. Gradually the 
speed diminished and the birds gave the last smoothing with the soft side of the head. This done, they started feeding. Their movements awoke their companion. Was the bath preliminary to the resumption of feeding after the nap? If bathing was the rule, the third bird did not observe it.

Before leaving I again tried to discover if any particular kind of noises disturbed them. Increasingly noisy raps (made within reason) had no effect. They looked up quickly but did not appear alarmed when I whistled; they disregarded hissing sounds and notes which I fondly thought might resemble the cry of an owl. I could have stood up in the canoe and waved my arms, but I felt that I had been treated as an old friend who had been tried and found without evil intentions toward them. Touched by this display of confidence, I prepared to leave. The stadium was now as empty as it had been when I arrived in the morning. I looked once more for the mallard hen and chicks but they were nowhere to be seen.

My departure caused no excitement. The birds were evidently still hungry, for as the canoe slipped off the bar and I dipped my paddle, I saw them again pushing their long bills into the soft ooze of the bottom.

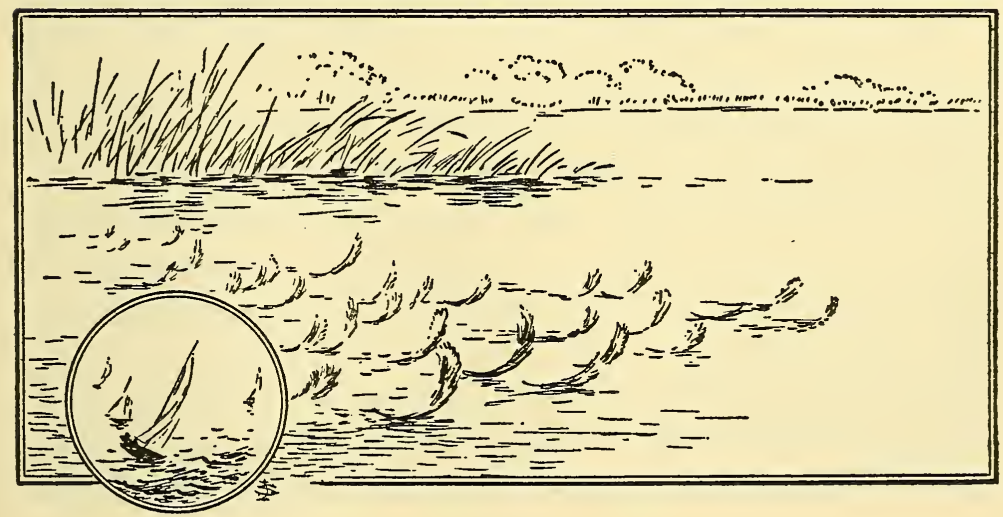




\section{Sky Sweepers}

\section{1.}

I SUSPECT THAT NO OTHER BIRDS have the world-wide standing of the swallows. Waterfowl are widely distributed, but their usual habits do not bring them close to man; shorebirds are hard to distinguish; gulls have so many plumage changes that identification of species is not easy; many small birds keep pretty well out of sight. But swallows are known almost everywhere.

I thought of them one day in the football season shortly after I had simultaneously watched the dowitchers and listened to the football game. The fall birds had begun to arrive in the bay. Diving birds fed in various spots: the eared grebes in the areas close to shore and one common loon in the open water near the entrance to the lake. For the hundredth time I tried to stalk a loon and get really close to it, but, as usual, its body, slaty gray in fall plumage, disappeared in a smooth dive and reappeared in unpredictable places, sometimes in front, sometimes to the side, of the canoe, but never close. The western grebes, almost as large and equally proficient as divers, were less wary. Though their underwater directions were never certain, they sometimes came up within a few yards of me. They were graceful birds 


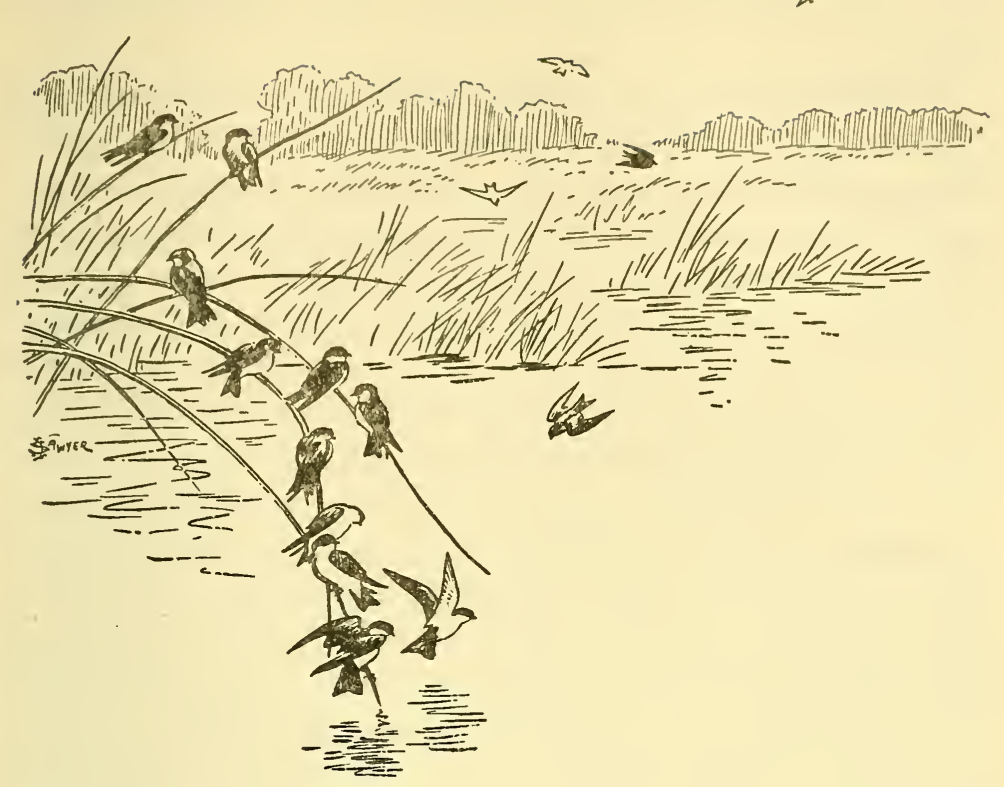

with gray back, black top of head and back of neck, and white underparts. In some places their graceful necks, much slimmer than those of the loon, have given them the name of swan grebe. One of them paddled along with what I thought was a broken and projecting wing feather, but it proved to be a leg held over the side of the body in a strange and puzzling manner. I thought its position was probably due to injury, an idea which was soon dispelled when I saw others of the five birds in the group, floating along with leg held in the same grotesque fashion.

Something seemed to be lacking in the marsh that day. I did not know at first just what. Then I realized that the swallows had left. Thousands had congregated in late August. Most of them disappeared a week or so later but small flocks had still flown about. On my previous visit three of them had 
searched busily for insects over the water. Where had they gone?

I could have answered the question without difficulty had I been a Greek follower of Aristotle. Observers in the Middle Ages would have had a ready explanation. I could have gotten the same ready answer from the country folk and even from the scientists of a couple of hundred years ago. All would have said that, summer being over, the birds had hidden themselves in dark caves or crevices where they would remain until spring, or they had buried themselves in the soft mud of the marsh where anybody who knew how to find them could dig them out. If I had been incredulous, many reputable witnesses could have been produced who had seen them in the very act of submerging: they had crowded a bulrush to such an extent that the stalk yielded slowly and gracefully to the strain and the whole mass approached the water steadily. I had seen this performance many times in the fall; how could I doubt the veracity of the witnesses? Of course I had never seen the birds actually submerge. In fact, I thought them young birds which wanted to flock together and which had shown bad judgment in overloading their perches. They had always flown away just at the moment of immersion. Perhaps it was only my misfortune or lack of persistence which had prevented me from seeing the actual entry into the water on their way to the soft security of the marsh bottom. The arguments against me would have been heavy if I had tried to deny the hibernation. Did not the birds congregate in large numbers and then disappear practically over night? Had anybody seen them afterward? They could not get insect food in cold weather and they must seek a winter hiding place. Did not mammals and fish hibernate? Why should not birds? I could see little chance of winning such an argument.

I thought it strange that the belief in the hibernation of swallows had persisted for so many centuries. For swallows 
must always have been known to people. In many cases, the disappearance of their original type of nesting sites has caused them to live in structures erected by man. Usually the birds feed at a level low enough to be seen easily. They take insects stirred up by the feeding chickens and the moving livestock. They are friendly, gregarious in their habits, and numerous. They are so well known that they are mentioned in history, fable, folklore, and legend. They were referred to in early literature. I wondered what these early writers knew and thought about them. Perhaps a sketchy sampling of early writing might give information concerning these birds and the general status of bird knowledge, as well.

Aristotle, the Greek philosopher who lived in the fourth century B.C., had discussed them. He wrote that some birds had feet of little power so they were called apodes. Such birds were powerful on the wing and, as a rule, birds which resembled them were weak-footed and strong-winged like the swallows. Their nest building denoted great intelligence: the swallows mixed mud and chaff together and, if mud were not obtainable, they made their own by sousing their bodies in water and rolling about in the dry dust. Parents cooperated in the training of their young, feeding the nestlings each in turn, removing droppings from the nest at first until the young themselves learned cleanliness. He said that the swallows bred twice a year instead of once as did most other birds. Swallows are among the worst enemies of bees. He described the position of the bird's gall bladder and the shape of its stomach. He thought that some birds practiced hibernation and swallows were among them. They had often been found hidden in holes, quite denuded of feathers.

He might have gotten away with such a talk today if he had delivered it to people who had paid little attention to nature. It indicated field observation, examination by dissection, and an attempt to draw conclusions from the evidence. There were some obvious errors but there was enough truth 
so that for centuries Aristotle was the great authority on the subjects about which he wrote. And this in spite of statements such as these: injured wild boars hunt a plant called dittany to eject arrows from the body, the weasel eats wild rice before fighting the snake, a stag wounded by a venomous snake gathers crabs and eats them.

Four hundred years later, Pliny the Elder, a Roman, referred to swallows in the chapters on birds in his Natural History. Much seemed to be a rehash of Aristotle with the addition of some of the popular beliefs of the period. The swallow, he wrote, would not enter a house in Thebes, because the city had been so often captured, nor would it approach the country of the Bizyae because of the crimes that had been committed there. Certain of the Romans used the swallows as messengers of victory or for carrying other news. In Egypt, the swallows yearly strengthened with chaff and straw the shore of an island sacred to Isis and thus prevented the annual floods from destroying it. This task was of such magnitude that it required three days labor and so difficult that it resulted in the death of many of the birds. These stories are of the "It is said" variety so that it is difficult to know whether the writer actually believed them or whether they were thrown in as a stimulant to the reader.

The swallows must have been known to all. The Bible speaks of them. The Psalms say "Yea, the sparrow hath found an house, and the swallow a nest for herself... .." Hezekiah, King of Judah, recovered of his illness, wrote, "Like a crane or a swallow, so did I chatter." The poets did not neglect them: Chaucer confirmed the bird's chattering mentioned in the Bible with the following: "As any swalwe chitteryng on a berne." Elsewhere he refers to "The swalow, mortrer [murderer] of the flyes smale," and "The swalwe Proigné, with a sorwful lay." Shakespeare asks the following question: "Do you think me a swallow, an arrow or a bullet?" and elsewhere remarks: "True hope is swift, and flies with swallow's 
wings." Tennyson beautifully states: "For knowledge is the swallow on the lake." Elizabeth Barrett Browning writes an "Ode to the Swallow." Few poets have omitted some reference to these birds.

The swallow is found among the fables. There was the bird who had built her nest under the eaves of the court of justice and whose young had been devoured by a serpent. When reminded that others had met with similar misfortunes, she replied that she mourned not the young ones but that she should have been wronged in the very place where the injured fly for justice. And there was the discussion of plumage between the raven and the swallow. It ended by the raven saying that the swallow's beauty was but for summer while his would stand for many winters. The folly of overestimating one's capabilities is shown by the spider which, hating the swallow because of its competition, decides to snare it. The extra heavy net does entangle the swallow, but it soon flies off uninjured and carrying the entire net, thus convincing the spider that it had better stick to the catching of flies.

Here is an old recipe which indicates the swallow's connection with superstition and love potions:

If anyone takes its [a swallow's] young ones, and puts them in a pot, and when it is luted up, bakes them, then opening the pot, if he considers, he will find two young ones kissing one another. If, therefore, you take those that kiss one another, and dissolve them in oil of roses, or give the ashes to drink, it is a love potion.

Some of the American Indians, ordinarily indifferent about small birds, were fond of the martin. They erected nests by putting gourds on crossbars at the top of long poles and thus protected the birds. It is said that they and southern Negroes who still follow this practice believe that martins keep away the hawks.

All of this tells us much of the position which the swallows 
occupied in the communities, but it gives little indication of the progress of knowledge about them. The advance must have been slow. There could have been little accumulation in those dull and unreceptive centuries which followed the period of Rome's greatness and accompanied its decline. Religious thought not only dominated but almost displaced scientific thought. Study became mere routine and was constantly interfered with by the religious authorities. The Greek manuscripts lost their standing and were seldom read. The Physiologus and the bestiary, first intended to describe natural subjects, became merely moral comments on real or mythological animals and without scientific value.

This is no place for a lengthy report on the progress of the next centuries. Here and there great figures appeared, some like Neckam and Albertus Magnus to revive interest again in the early philosophers; and others, from early in the sixteenth century, to begin work in various fields and to set the stage for modern science. Several books on birds were brought out, promising in that they contained some material based on personal observation, but still including many statements from the old traditions. The time came when the astronomy of Ptolemy was replaced by the researches of Copernicus. In the first half of the eighteenth century, Linnaeus produced the Systema Naturae which catalogued and methodically outlined the arrangements of plants, animals, and minerals. Its later revision, by Cuvier and other men who followed, resulted in a system which, except in certain details, is still in use. The extension of the use of the microscope, the emphasis on anatomy, histology, physiology, and other branches promoted the rapid advancement of biological science and helped to bring it to its present state.

Knowledge about swallows must have followed the progress of ornitholngy and accumulated slowly. It is said that nearly two hundred papers and articles were written on the subject of the hibernation of the birds before the theory was 
generally discarded. It is certain that here and there people will be found who still believe that it is a regular and, common practice. As late as the middle of the eighteenth century men had made affidavits that they had seen swallows revived after winter burial in the mud. Some of the attestants were well known and of good standing. Many of the scientists continued to point out that if fish and mammals hibernated there was no reason to believe that birds did not or could not.

Most superstitions have vanished, if slowly. We no longer accept the idea that swallows avoid certain places cursed by the gods. Nobody believes that the bodies of swallows are of value for making love potions or for use in auguries. Few could be persuaded that the birds ever went yearly to a sacred island and worked for three days to save it from the floods. Nor do we accept, offhand, Pliny's statement that swallows are never preyed upon by the hawks, for we know that at least two English birds, the hobby and the merlin, do take them.

As men went into the field, much of the information collected was local which could be compared to that which I might gather if this district had been continually isolated from others. If I were fortunate enough to watch the arrival and departure of the seven species of swallows which visited this area, I would not know where they came from or where they were going. I could learn much about the four species which remained to nest: the sites they chose, the date when nesting began, the number of broods raised, the number of young in each brood, the time they left the nest, and their early behavior. I would find that if I blew small feathers from my hand during the nesting season, the barn and tree swallows would swoop down and pick them up before they struck the ground. I would be able to recognize the young birds by their unsteady flight and would often see the old birds feed them on the wing. I might make thousands of such limited observations, but I would have little opportunity to 
study altitudes in which migration was conducted, whether it was by day or night, whether the birds fed as they flew, whether their flight was hurried and conducted on the energy of the fat which they had stored previous to the start of the trip.

The progress of science has altered these conditions. Much research has been done in the field and the laboratory. The data thus obtained have been checked and rechecked. The results of widely scattered workers are continually being consolidated. Information formerly known only to the man who had gathered it is now available in manuscript or printed form or in lectures and is constantly put to use. Special monographs on the physiology, anatomy, and histology of one bird are often available. Lengthy life histories of species have been prepared. Arthur C. Bent's Life Histories of North American Birds already includes eighteen volumes and several more will be required to complete the series. The literature of ecology and of all kindred subjects has increased rapidly.

In terms of the four swallows which nested in the marsh, this means that it is no longer necessary, as in the early days of field watching, to rely solely on one's own experience and to suffer from the lack of it. Comparatively speaking, the life histories of the swallows are fairly complete so that, for example, I can obtain from the available literature such details as range, winter residence, migration and arrival dates, plumages at different ages and seasons. I was astonished to learn that the cliff swallow, which I had known only in a more or less local manner, actually ranges over much of North and South America, going as far north as Alaska and as far south as Argentina. I can compare my own nest observations with those of others living in widely separated places who have also investigated location, speed of building, material used, number of eggs in the nest, and variation in marking. I pick up information on the time when the eyes 
open, the beginning of preening, probable flight distance per day, and feeding habits. There are many actual experiences of field observers to verify or contradict my own field findings. And if I wish to go further, I can always consult the writings of men who have specialized in fields in which I am personally interested.

My research need not be limited to the swallows of the marsh. The literature discusses the members of the swallow family all over the world. I can find how widely the birds are distributed and much about their habits, size, and speed. There will be big birds and very little ones, and highly colored species which add so much interest from a popular standpoint. If I want foreign information on technical problems, it will be available, often in greater detail than in the writings of Americans in the same fields.

We have made considerable progress since Aristotle wrote about swallows. Man, not content with blindly following the lore of the ancients, and freed from the shackles of dogmatic religion, has struck directly at the core of truth. By intelligent observation and use of the scientific method, facts are discovered and their significance recognized. Careful field studies, detailed analyses of the natural environment, expeditions of trained personnel, publication of findings, bird banding, and the building up of specimens collected for laboratory study-all have played their part in our advance of knowledge so that a few tattered legends have been replaced by a mass of concrete facts.

It all sounds delightfully final until I raise questions like this: We know many things about migration, but exactly what causes it? Much is known about the return of swallows to the identical spots which they occupied the year before, but precisely how do they do it? And when no eager hands are raised to answer and explain, I feel that, perhaps after all, we are still a long way from the solution of the real problems. 


\section{Wild Fowl and Men}

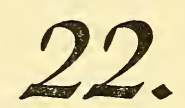

I VISITED GADWALL COVE THREE weeks after my pigskin-dowitcher experience. The little bay had lost its tidiness, for the cattails and rushes had yielded to the fall winds and rains and had begun to slip into irregular clumps. But if the primness was gone, the pleasing color change compensated for it. Many of the loosestrife leaves had assumed shades of brown and red which suggested the huckleberry foliage of the high country. Perhaps half the cattails were a dark tan. The massed vegetation had become a heather mixture-pleasing browns, reds, and greens, softly blended.

The gadwalls were visiting the marsh on their fall migration. Five of them watched my approach, all riding high: the males, slim-gray and black-rumped; the females, brown and inconspicuous. Almost before I raised my binoculars the birds left the water, forcing their whole strength into the action of lifting. They quartered as they rose and then, with full speed acquired, they straightened out and moved downwind toward the south end of the marsh. There was no hesitation, none of the uncertain flight of the grebes, the bitterns, and the coots; instead, they displayed immediate reaction and made a speedy and decisive exit. 


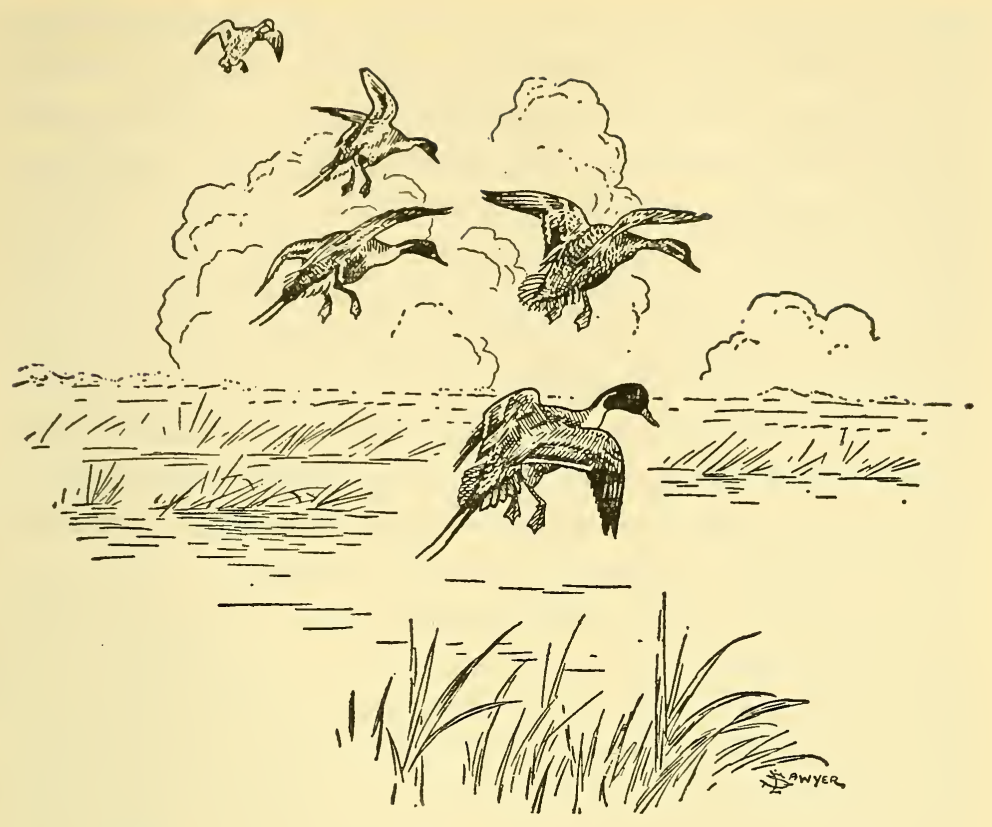

I suspect that it is well that wild fowl have developed this alertness and speed, for they have never been free of severe hunting pressure. Wherever there are coast lines, lakes, and sedgy rivers, the birds have congregated, and wherever they have collected they have been preyed upon by hawks, owls, and other birds, by foxes, minks, by men, and other mammal predators. The tremendous extent of the predation indicates how highly their fat and tasty bodies are esteemed. Even the pike, pickerel, bass, and turtles are said to take the young whenever possible.

In the marsh shooting is prohibited, but ducks are not entirely free from molestation. Boys with airguns or small caliber rifles occasionally run wild and shoot at everything they see. Rarely the birds are poached by men in boats. They take one or two shots into a flock, pick up the victims, and leave immediately. Traps set for muskrats and baited with 
apple are deadly when ducks are hungry. Slingshots destroy a few of the tamer mallards. In addition to these routine types, other methods occasionally turn up. Such was the device I discovered one day when I followed a new route into the cattails and toward the willows. At first I did not know whether it had been made by boat, beaver, or muskrat, but when I forced my canoe over the wet path, I found a V-shaped fence of low poultry netting covered at intervals with vegetation to camouflage it. The netting on either side terminated so as to leave a ten-inch opening at the point of the $V$. Above this opening I could see a cord hanging from the bent branch of a willow and terminating in a noose which hung in front of the passage.

It was a snare-the first which I had discovered in the marsh. Somebody had considered it a quiet and efficient way of getting ducks, and as there is nothing exciting about snaring birds, it was quite evident that the trapper was primarily after food. Perhaps the builder was a foreigner who had trapped birds before leaving a country where snaring and liming and netting were considered not only legitimate but thrifty and respentable. Perhaps a boy who had read accounts of such devices used by the early pioneers had fashioned the device. It might have been made by a sailor or miner who had lived near the Alaska Indians and had watched them snare birds, a practice in which even the youngest boys excelled.

A song sparrow flitted among the lower parts of the cattails and watched me as I looked at the snare. My movements were slow, I made little disturbance, and if the bird had any fear it was more than overbalanced by its curiosity. I found this species everywhere in the marsh, and usually displaying a considerable amount of interest when I stopped.

I was interested, too. Except for the substitution of wire netting for a fence of woven twigs or brush and a machinemade cord for a strip of hide or twisted fiber, it might have 
been made many thousands of years ago, for I suppose the snare is probably one of the oldest methods of taking game. What could have been simpler for primitive man than to twist fibers or grasses into a line, to fashion a running loop, and then to sit and tighten the noose about creatures which would not allow a close enough approach so that he could seize them with his hands or strike them with his club. Fish, birds, or mammals could be taken that way by a patient watcher. Then, someday, an impatient hunter must have realized the possibility of fastening the line in such a way that the animal would spring a device which would tighten the loop and make constant attendance unnecessary. And surely even a Neanderthal or Piltdown man might comprehend that a fence of brush would lead the creature to the noose. Nothing more could be done to improve the snare; the results would be bettered only by skill in placing the contrivance. I could look back and think of myself as an awkward, stooping, long-haired, and dirty man, clothed in an animal skin and parting the cattails with my club, as I looked through the growth to see if any fowl or muskrat had wandered into my trap. I suspect that the picture would have been much the same whether in the fens of Great Britain, the tundra of Alaska, or the marshy lakes of Africa, for all hunting tribes must have taken to snares as naturally as to clubs and spears. The special hunting devices originated by tribes and nations all over the world probably came later than the simple snare. I watched the one in the marsh, but it was never sprung and the vegetation covered it at last.

What a documentary film could have been made of the methods of taking waterfowl that I had seen or read about! Scenes might be reconstructed to show the Egyptians hunting with their spears, using their cats, one of their sacred animals, as retrievers. The film could portray the falconry of the Middle Ages with all the pomp and brilliance of that ceremony, the horsemen of the South American pampas 
throwing their whirling bolos, the boating drives which ended in the slaughter of thousands of birds on the lakes of Mexico, Eskimos standing in the fog on high points along the spring flights of the birds, using large handnets to transform magnificent flight into crumpled inertness. Grim but revealing would have been the summer drives when the wild fowl could not fly, the young because they were too young, the mature because they were moulting. Mighty was the slaughter and more terrific the waste because only the most desirable birds were saved. More easily recorded from a photographic standpoint would have been the skills of the individual: the snaring, the shooting with bow and arrow, or the killing with the spear, or ancient sling. Then there was the netting and the basket traps. Most picturesque of all was the approach on the surface of the water of the moving basket which covered the head of the hunter. When he got within reach, the hidden man would seize the unsuspecting birds, pull them beneath the surface, and wring their necks.

- These were but a few of the methods, some long abandoned, some still in use, that might be photographed. I. grew quite enthusiastic until I thought of the difficulties in the way-of the distances to be covered, the necessity of being on hand at exactly the proper time to view the methods of the present, and of the complications of reproducing those of the past. Most of the ancient scenes would conflict with the game laws. For example, the taking of ducks with falcons could be done only by special permission, if at all, and the conservationist would probably regard it as an unjustifiable sacrifice to history. And as for the wild fowl themselves: they doubtless would be unable to derive much satisfaction from the thought that having their legs snapped by flying bolos or their necks twisted by a man wading with his head under a basket would be a considerable contribution to the pictorial representation of hunting methods of the past. I decided without further reflection that no individual 
could properly attempt such a task and I must stick to the written word.

But the great number of methods of taking wild fowl did indicate their importance in the economy of all nations. Wild fowl must have been a considerable part of every larder when weapons were poor and large animals difficult to obtain. I imagined ancient man, after a vain attempt to kill a wild ox, slipping down to the marsh in order to get ducks or geese for his meal. Hunting was a means of filling one's belly and not a sport, and wild fowl were numerous and unafraid. In many places they remained the year around. Eggs could be hunted by women and children. The plumage furnished material for ceremonial purposes, for decorations, and for warmth. There were many reasons why the hunting of wild fowl through the centuries had been continuous and heavy. Were the birds successfully meeting the pressure?

Survival to the middle of the nineteenth century was not difficult and could be easily understood. The great nesting places of the ducks were undisturbed, the migration routes full of undrained marshes and good feeding grounds. Hunting pressure was that of a comparatively small population, weapons lacked modern killing power, and transportation was limited and difficult. Many ducks were killed yearly, but it is quite certain that the annual crop of birds successfully offset the loss.

The view of the marsh in front of me did not indicate that there was any great present shortage of wild fowl. I saw a flock of several hundred baldpates in the center of the bay. They had come in during the past ten days and would remain in about the same numbers (although individuals would come and go) until the last of November. Scattered over the bay were other common duck visitors.

The birds about me fed contentedly. Superficially, there were no signs that the hunting season had begun and that in other marshes death had come to many waterfowl. I was 
reminded of it when I flushed some green-winged teal and all but one of them flew away with the incredibly high speed of this smallest and fastest of the ducks. The one bird tried but could not rise. It had been the victim of a shot and had made its way to this little refuge. Its efforts to dive failed, but as the canoe approached the bird managed to splash its way to the cattail cover.

I had watched this scene yearly. No need for me to look at the hunting schedule: the state of the marsh told me when the season had opened. Already there were four other cripples: two pintails and two mallards. I saw them, as I had seen wounded birds in other years, alone, moving slowly along the edge of the cattails or resting in the weeds or on a projecting log. They seldom strayed far from the place where I first saw them. A few yards or a few rods, the distance being determined by their physical condition, was the limit of their boundaries. I came to know them by their location, and each week I watched for the mallard near the willows or the pintail close to the tule wren's nest. When I observed that the patient was improving, the knowledge added much to my day's pleasure. Twice when I missed a bird I searched and found its body in the reeds.

Most impressive of all the marsh patients was a snow goose which arrived one October afternoon when the Cascade Range had just begun to appear through the dissolving mists and when the morsh lay sodden after a three days' rain. The bird flew from behind a little point of cattails from which the canoe had startled it. As it flew I could see that the flight was labored and that there was something wrong with the beat of its powerful wings. A break in the wing action, the failure of a gallant attempt to maintain elevation, and the bird struck the water like a weight instead of a living creature, and then struggled away into the twilight. Wounded, it had sought sanctuary in the marsh.

I purposely tried to keep away from it on my next trip, 
but a week later I flushed it accidentally from some mare'stail which lay thick in a little cove. It got up but only with difficulty. This time it did not fly alone; a smaller bird, a cackling goose, rose with it, and the two strangely contrasting geese, one white-bodied except for black wing tips, and the other brownish and black with white patches, flew off together and landed in the open water of the bay.

An unusual association began. These birds kept so close together that, whether they were feeding, flying, landing, or swimming, I never saw one without the other. Each week I expected to find that they had left, for in this small area geese had never remained for more than a week at a time. Invariably I added them to my list of guests present. Winter moved in but the birds did not move out. They faced the cold weather of December when thin ice formed on all of the channels. I found them side by side after our only severe January snow. By this time I could approach more closely than earlier in the season. They seldom flushed but simply paddled off as fast as the situation demanded. Why did they remain? The snow goose now flew straight, but perhaps it lacked the strength for a long flight. But what held the cackling goose? Why this curious attachment? Sympathy? Loyalty? Are the members of this group naturally associative? I wonder. February came and the nearby hillsides began to turn green. Then the mare's-tail popped out in places where the water was shallow. Spring had come to this marsh hotel and with its coming the geese had flown.

It was not only the wounded birds that sought the protection of the marsh. Canadian and white-fronted geese, whistling swans and other strangers, which apparently had been hunted and were unable to find resting grounds free of shotguns, came and fed greedily. They either ignored me or they would paddle ahead of the canoe and snatch a leaf in the same way that a cayuse snatches a bite here and there as it follows the trail. One little flock of ruddy ducks landed so 
close that their spray sprinkled the canoe, and they immediately began to eat the floating duckweed in great and noisy gulps. When I observed their hunger I began to realize the value of these small protected spots. My early conservation ideas included refuges of thousands of acres. I have since learned that any place, regardless of size, will be used by ducks if they can feed unmolested. The action of these birds and of many others demonstrates that at times these little sanctuaries are desperately needed.

I continued my trip and approached a flock of pintails. They paid little attention to my slow progress. They had not been in the marsh long and would go soon, for they were among the birds that used the place only temporarily. I did not know exactly where they had been raised, for the pintail breeds along the long coastal strip north of us to upper Alaska. I did know that, like all ducks, they had been subject to predation from the day the first egg had been laid. If the nests happened to be near the villages or camps of the natives, the children had raided them constantly and had continued to harry the young until they left. And there were the coyotes, the foxes, and other mammals which kept fat by locating the eggs or young. The predatory birds would share in the feast, and patrolling gulls, skuas, jaegers, and ravens would dash down upon any unprotected nest. And there was the hazard of storm and drought so that the mortality during the nesting has been estimated as more than fifty per cent-few observers have thought it less.

I would have liked to know the history of the flight that brought these pintails from their nesting grounds. Had they been raised near the Yukon River or farther south? Was it a leisurely or fast journey? Had the birds been raided by the bold duck hawks which stationed themselves on rocky headlands and sallied forth like the pirates of old to take toll from those which passed? Had they found plenty to eat or had 
the attempts to drop into good feeding areas been repelled by hidden gunners?

The birds swam gracefully about, now and then up-ending for food and occasionally uttering their soft calls. Not more than a city block away a tug passed through the canal on the way to the airfield. In the opposite direction I could hear the football coach as he megaphoned his commands to the squad on the practice field. From the tone of his voice I judged that he thought some improvement could be reasonably demanded. The sun grew warm enough so that I could take off my coat as I watched the birds. No need to confuse them with any other ducks: their long and graceful necks striped with white on the sides, their sharp pointed tails, and their trim appearance instantly separated them from any other wild fowl which visited the marsh. When they reached under water for food, their tails projected like a cardboard triangle. Nearby were coots and a pair of pied-billed grebes and close to the cattails stood a great blue heron-unafraid wildlife in the midst of a city.

As I watched the pintails I thought: they had better take a good rest for they will need it after they leave here. They will find very few places like this. A small powerboat cut closer than the pintails liked. They rose in a little flock and moved to shallower water where they resumed feeding. Would this temporary freedom from interference make them less likely to inspect the safety of their next resting place? I feared that it might. Yet they had much need for wariness, for they would face the peak of the hunting season. What were the problems of waterfowl which were heavily hunted? I remembered a remark I had once heard: if you want to understand the working of the whole, it is sometimes better to consider the working of its parts. I changed my question: what is the typical history of a little group like the nine pintails feeding before me?

I could easily visualize what might happen at the next 
stop, or the next, or the one after that. They would follow the historic route of their ancestors and at the end of a long fight would sight a lush spot. They would turn toward it and, with food and shelter just ahead, would set their wings in that magnificent approach so typical of the pintail-wind whistling through the motionless feathers. The water would be a few feet below them, the flight almost ended. Movement would begin in the tules, gun barrels would lift and blast. The bewildered flock would change direction and veer away. Two or three of the nine birds would be left behind, and while a dog leaped overboard to retrieve them, the men would congratulate each other on the excellence of their shooting. And it was splendid shooting, good retrieving, and fine sport for all the participants except the ducks. Where can they go next?

As the pintails move along they may find small havens where they can stop, but the best marshes-the ones which, in the undisturbed periods of the flyways, welcomed and cared for tremendous concentrations of wild fowl-are now lined with shooting clubs. The less productive spots are occupied by private shacks, and all the other areas which promise even fair sport will be filled with guns and hunters tucked away in blinds. How will our ducks react to such conditions? Will they have learned anything of wariness, or will they simply be dazed by the bombardment? When I think that I am overemphasizing the situation I recall the many millions of ducks which are taken during the hunting season.

There was no sentimentality in my speculation over the possible fate of the pintails. I have no objection to hunting if it is properly limited. Practicality has forced me, as it has forced most others, to accept in a more or less modified form the theory that man, self-assumed dictator, is entitled to dispose of all the lower forms of life as he pleases. I have heard all the arguments about harvesting the wild fowl crop and of the inalienable right of the sportsman to hunt and to make 
his own rules governing the shooting. So long as the principle of harvesting only the surplus is followed I do not complain, but, in view of our rapidly decreasing wildlife, I consider it the right of all to speculate whether present shooting regulations will insure a continuance of the wildlife supply from which the annual crop comes.

Some of my hunting friends would have me believe that the hunting season is merely a friendly arrangement between them and the ducks. I really think they believe it, but I am quite sure that the ducks do not. I tell the men that while it may be considered justifiable, it is nothing but the predation of the human mammal upon wild fowl and that all the seeming care lavished upon the birds is simply to increase the possibilities of future predation. The contrasts in our hunting code are curious-our wild fowl receive loving attention in three periods of their existence, but in the fourth and last are subjected to the bloodiest gantlet ever run by living animals. They get a continually increasing amount of care in their winter quarters, they are watched and assisted in all practical ways on the breeding grounds, they are guarded by game wardens on their northward flight, but when nesting is over and they start south, it is a different story.

Then they receive the same treatment the Romans gave their gladiators. Rome furnished its stadium performers with kindness and luxury during the preliminary training period. The men lived well, they were visited by lords and ladies who admired their skill and strength and acclaimed them heroes. But all of this was forgotten when the gladiators strode into the arena: this was the time for which the spectators had waited, when the payment for the tenderness of preparation would be demanded, when the final settlements would be made.

Duck hunters recognize the needs of the ducks. They are all agreed that southward-bound birds must have food, rest, 
and shelter if sufficient breeding stock is to be available in the spring. On the other hand, the hunting season is the period of harvest, the pay-off. Consequently the hunters of each district favor refuges if they are not in their vicinity, but north or south of them. They want no local protection for ducks passing in the hunting season. What have wild fowl been raised for, if not to shoot?

I did not have to be an expert on botulism, migration, or the diseases of concentration to understand the main trends affecting the pintails before me. All of the four phases of their life had to prosper in order for them to perpetuate their kind. They must have proper wintering grounds, successful spring migrations, adequate nesting areas, and a return migration route which would insure the passage of enough birds to provide sufficient breeding stock. Failure in any of these factors imperiled future supplies. What was the effect of modern civilization on these factors?

I could see improvement in only one aspect. The prohibition of spring shooting had made certain the passage of a greater percentage of birds on the way to their breeding grounds, although, of course, the number of birds is only a fraction of the four hundred million which was the estimated population in 1850 .

In all other phases I could see only deterioration. The winter grounds continue to shrink because of the drainage and improving of farms, the advance of towns, the improvement of resort sections, and the determined préssure of ranchers who resent the damage done by the huge concentrations of wintering birds. The northern breeding grounds have been attacked by droughts, which rendered whole districts useless for years. The number of wild fowl which normally nest in the vicinity of farms has been steadily cut down. In my own case I could think of a dozen fair-sized marshes in the area where I was raised. All of them have been drained. Almost everybody I talk to has made similar 
statements. The restoration of some northern nesting areas has been well done, but the area reclaimed is so small a proportion of the total that the effect is almost negligible. Drainage, ditching, pollution, and dams make great changes. It is certain that land devoted more and more to the use of man cannot be expected to raise waterfowl crops as it did when it was in its natural state.

In the meantime, what about the pintails? I can merely speculate on their progress. And yet it is of the greatest importance that enough of them and those in other flocks get through. In their successful passage lies the future of the species. Without them there will be no activity in the nesting grounds. The winter will still be ahead of them and it too will take its toll. Only a small fraction of the millions of birds which winged south in fall will be left to begin the migration in spring.

Even without hunting the trend of wild fowl is downward. Steady decrease must be expected. Everybody who has studied the disappearance of once-plentiful forms of wildlife recognizes this. The predation of man increases this certainty, for it is different from the predation of other mammals. It is well recognized that the relation between wildlife predators and the preyed-upon tends to become stabilized so that the latter continues to exist. When the preyed-upon are greatly reduced in numbers, the predators lack sufficient food and must leave or die. Either result reduces the pressure on the prey and enables them to increase in numbers again. But there is no such relief from the pressure of the predator, man. The condition continues, unless man has the foresight to realize the position in which the victim is placed.

Man seldom has displayed this foresight. Natural causes finished the heath hen, the great auk, the passenger pigeon, the Eskimo curlew, but it was man who so reduced them in numbers that the species fell easy prey to catastrophes which it might otherwise have met without difficulty. 
What is man doing to the waterfowl population? Ducks, geese, and swans have withstood the attacks of man since history began-what changes have occurred that might make me think that the birds could not successfully withstand man's attacks in the future? Ducks are decreasing in number, man's predation increasing. Has man, in the face of curtailed breeding grounds, smaller winter areas, and limited migration facilities, accepted the situation by reducing the pressure on the wild fowl?

I thought that an examination of the duck stamp figures might answer that question. In 1935, when duck stamps were first issued, approximately 600,000 were sold, all to hunters, with the exception of a few purchased by stamp collectors and nonhunters who wished to indicate their approval of the movement. By 1940 the number had risen to 1,100,000. Although complete figures have not been received, present indications are that the sales for the season of 1950 will reach or probably exceed $2,000,000$. The national kill for 1947 was estimated at 12,000,000 birds, for 1948 it was $17,000,000$, and for 1949 the estimate was 18,500,000. Can any logical thinking justify a conclusion that our rapidly shrinking wild fowl winter, migration, and breeding districts can stand the increasing intensity of such pressure? I find no grounds for such optimism. I remember that in 1937 the waterfowl population dropped below $40,000,000$. I have noted the practical exhaustion of the ring-necked pheasant supply in the Dakotas-a supply which friends who annually hunted there had assured me was inexhaustible. I know that modern man can build rapidly but there has never been a time when efficient production could keep up with mass destruction. I realized that factors other than man's hunting affected the wild fowl supply. These factors constantly closed in and grew in importance just as the pressure of the city constantly closed in on the marsh. How, then, could man erect an almost continuous wall of shotguns between the breeding and 
wintering grounds and expect to maintain a continuous supply of ducks sufficient to meet the demand?

The pintails continued their feeding as I turned the canoe toward the float. They will have flown before my next marsh inspection. If things go well, next year some of them may call again at about the same time of year and in the same location. I wondered if I would ever fail to see these fine birds among the marsh rushes.

One of the factors needed to insure a continuous supply, I thought, was to recognize the imperative need for a series of "stepping stones," or as the air pilots would say, "refueling and regrouping bases," between the breeding and wintering grounds. Regardless of their size, a combination of such places would be of great value.

Waterfowl can be perpetuated only if hunting controls squarely meet the facts. This survival of the breeding stock is of the first importance. I hope that the hunters and conservationists, whose ways are so different, but who are equally interested in the long-range preservation of our wild fowl, will take effective steps toward that end. Otherwise, a series of those great natural catastrophes which sometimes appear may attack the shrinking breeding stock and reduce our wild fowl below the possibility of replacement.

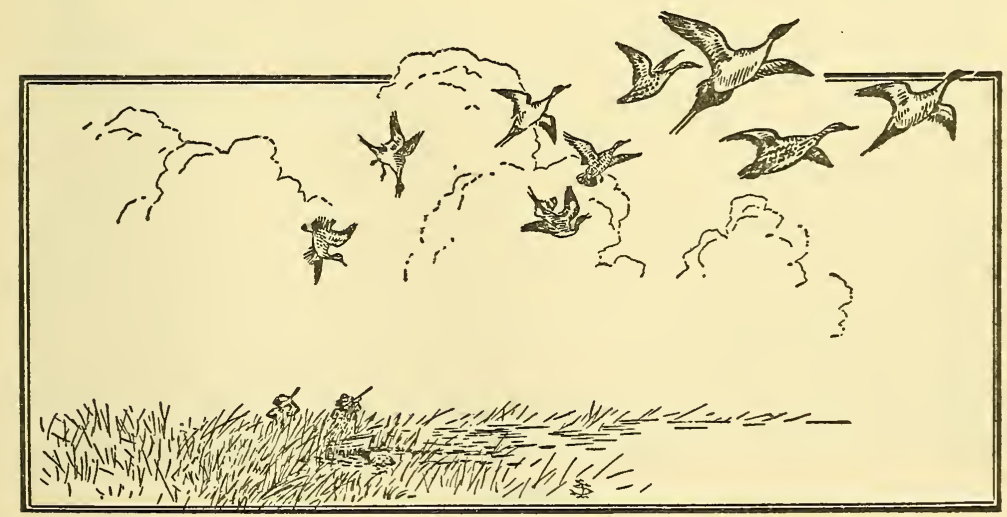




\section{Who Killed Cock Robin?}

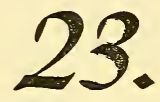

ONE FALL MORNING WHEN I PADdled along the marsh edge, I noticed a moving object on a log inside a little bay made by the recession of the vegetation. When I quietly forced my canoe into the open water surrounded by a brown ring of old and drooping cattails, I saw, much to my astonishment, a marsh hawk feeding on a bird which proved to be a green-winged teal. Once before I had encountered one as it started to tear open a coot. I had dismissed that incident without much thought. It was the first time I had ever seen the marsh hawk with a bird victim, although I had seen them beat the wet meadows day after day where the plentiful supply of ducks below them paid no attention to their passing. But this was the second case in the marsh, and I asked myself if in this area the marsh hawk is to be considered a regular predator on birds. Many people would have thought this second killing was all the evidence needed, but I had watched the bird too many times to be sure. For example, I saw the Cooper hawk much more infrequently, but I had watched it dash into flocks of small birds. Though the marsh was always full of larger birds in fall, I had never seen a marsh hawk attack one. Another thing 


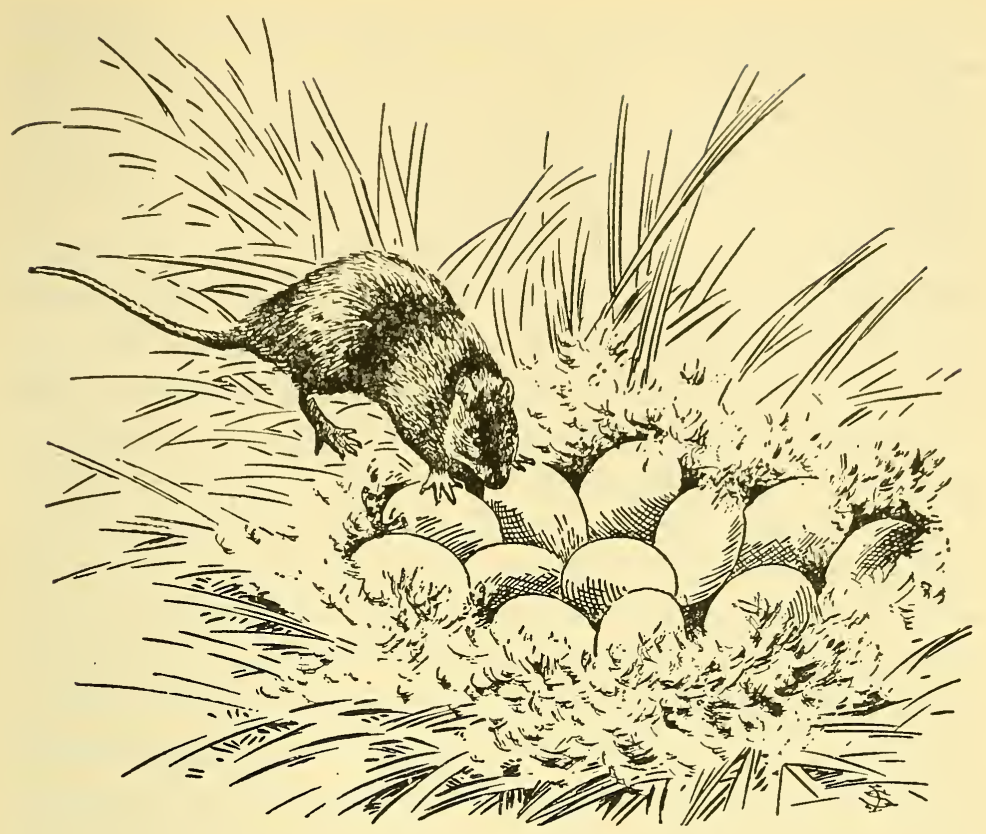

puzzled me: a coot could easily have been taken, but how could this slow-moving harrier have struck down the greenwinged teal, the fastest-flying of all our ducks? Perhaps the teal had been wounded and had sought a resting place in the area where, unable to move rapidly and perhaps nearly dead, it had fallen easy prey to a bird which, in a country where rodents were protected by plenty of cover, had found a meal in this stricken and easily captured victim. Possibly the duck had a broken wing inflicted by rock-throwing enthusiasts who frequently stood on the bank and used the marsh birds as targets. At any rate, and regardless of the manner in which it was taken, the marsh hawk was ripping it to pieces with its powerful bill. The responsibility for its death, in the absence of proof to the contrary, was chargeable to this brown-bodied and white-rumped creature which reared itself so fiercely above its victim. 
I checked the economic status of the bird that night. Authorities practically agreed in considering this hawk of much value as a destroyer of small rodents and mammals, its principal fare. But all of them reported that, while feeding its nestlings, it is a frequent or regular predator on birds. The artist and ornithologist, Allan Brooks, reported it as "the most destructive bird in America to our marsh nesting water fowl for at least three months of the year." The general opinion appeared to be that its value as a predator on mammals outweighs its damage as a temporary predator on wild fowl and other game. This type of summary is accepted by few laymen for the reason that the bird often performs its beneficial acts in one territory and its harmful ones in another, and for that reason is known to local residents as being entirely good or entirely bad. Indeed, I am sure that the custom among the general public always is to regard a bird or mammal in this manner, the judgment being almost always based on its conduct in the one district in which the observer lives. Many hunters, on the other hand, consider all hawks and owls harmful and seldom admit that any are beneficial.

I think this attitude goes far back. When I was a very small boy I read much about birds and beasts in fairy stories and fables. I found that the animals were rated good or bad, the bad ones being especially bad, and the good ones unbelievably good. The bad ones played despicable tricks upon the good wild creatures. In these stories the fox was always cunning and unscrupulous, the wolf hungry and mean, the jackal low and treacherous. As for that archer, the sparrow who confessed to killing Cock Robin, he was so entirely set apart from the realm of good citizens in my juvenile mind that I never passed a sparrow in a vacant lot without recalling the miserable crime of its ancestor.

Many of us change such opinions as we grow older, but I am amazed at the extent that these prejudices still hold good. Most wildlife still wears a tag which expresses the popular 
opinion: the eagle is regarded as a child stealer in spite of the fact that a friend of mine, who has for fifteen years investigated such charges, has never been able to substantiate a claim of child injury. The wren is considered a confiding and altogether sweet bird, although it is often extremely quarrelsome and domineering and has been known to pierce the eggs of its neighbors with its bill when nesting competition is too severe. The hawks, even those which are of much value in the elimination of rodents, are "vermin," the name given to mammals difficult to control, and deserving of extermination. The owl is a murderer while the squirrels, frequent nest robbers, are highly regarded. The coyote, an inveterate mouser, receives no credit. In the marsh the single pair of kingfishers which sometimes appears is hated by sportsmen, who would welcome their elimination. Wildlife is classed everywhere in an entirely arbitrary and often unfair manner.

It is not a new thing, this attitude toward wildlife. A friend, a collector of old books, recently loaned me an English publication of 1841 written by a man named Hone and called The Year Book. Among its many miscellaneous items is one which says:

Bullfinches return to our gardens in February. The mischief effected by them is trifling. It was supposed that they deprived us of a larger portion of the buds of our fruit trees. It is now an ascertained fact. that they only select such buds as contain the larva of an insect: thus rendering us a kindness by destroying an embryo, or colony of injurious creatures.

We can imagine the history of this bird: first maligned and persistently persecuted because it ate the buds which, if unmolested, would have produced fine fruit; afterward praised and protected because the buds it ate were worminfected and would have been of great harm to the tree. Formerly maligned, it then became the pampered dweller in the English hedgerows. 
This seemed to settle definitely the status of the bird, but out of curiosity I consulted one of the best English works on ornithology (written a century later). The writers make no mention of the diseased fruit buds and give a distressing account of the bird's food habits: chiefly buds of fruit trees in spring (pear, apple, plum, gooseberry, currant, etc.), far more being destroyed than eaten. What are we to think now? Could it be that the report of the bird's eating only infested buds was a mistaken one, or has spraying become so efficient that the birds have been forced to abandon selectivity and must eat the good buds minus the animal flavor? I regret that the book made no other comment on the bird's economic status.

I have placed the local predation of the marsh hawk in the same category. I have watched it beat back and forth, flying low, with strong steady wing beats, its long body and white rump patch instantly identifying it. I have not watched it feed again nor have I seen it stoop at a victim. I have not passed any dead bird which showed evidence of having been attacked by hawks, nor have I seen any of the scattered feathers and other tell-tale signs of a hawk's feeding. Although I have no certain proof, I feel that the marsh hawk is not a bird predator in our area and that the coot and teal must have been crippled when taken.

Predation in the marsh and elsewhere will never cease. The manner in which it is practiced does much to bring about the prevalent opinion that an animal is all good or all bad. Much predation goes on quietly in the dark or far from human habitations or under conditions which people seldom see. Sometimes nests are raided and the young killed, without the knowledge of nearby residents. Eggs are taken from the henhouse by animals so clever that only the diminishing number indicates that theft is going on. Young chickens and even suckling pigs can be removed without disturbance, and often the owner has no idea of exactly when or how the 
theft occurred. When finally discovered, there can be no definite placing of blame but only a vague idea that a coyote, fox, hawk, or dog is responsible for the destruction. For example, at one time a mallard nested within a few yards of the canoehouse. I saw the fourteen eggs which the nest contained on a Friday evening. The next morning when I passed, the hen was gone and the eggs had disappeared. There were no signs of tracks about the nest, no shells, no evidence. If the young had come off, they would have been close to the nest or in it. They were nowhere to be seen. I never found out what had taken them, although the canoehouse manager was sure that the rats were responsible. Such cases often happen.

There is another type of predation which immediately makes itself known, and as quickly brings about the demand for the elimination of the offender. I refer to the appearance of the raiding "hen-hawk" which boldly enters the hen yard and then flies away with its victim while the rest of the flock sets up a squawking, which brings the poultry owner out to watch the tragedy. There is the wandering otter which stops at the farm pond and scoops up a fish while the women of the house wish that John were there with his gun. Then there are visits of raccoons which show little fear and impudently take their prey when it pleases them. The animal may never again appear on the scene, the total loss from this "showy" predation may be inconsiderable, but from then on the offending creatures and their distant relatives are marked, and unseen losses invariably charged to them. The destruction may be the result of the predation of other animals, hidden and unsuspected but constantly present in the area in large numbers. Predation is one field in which it certainly does not pay to advertise.

In our marsh hotel the mallards bring off broods of young varying in numbers from three to fourteen. People who regularly canoe learn to recognize some of the broods by their 
location, size, and the actions of the hens. The canoeists watch with concern the shrinkage in the numbers of the ducklings. Day by day the losses continue until the broods of twelve are reduced to perhaps five or six, and the hen which began with three will be swimming with one lone baby trailing her. At long intervals a mink will be seen taking a bird or feeding on one in late evening. The result is that the mink is held responsible for all the duck losses. When it is mentioned it is usually referred to as that killer.

Now the mink, which is a member of the weasel family, is a killer, which under certain conditions may be chiefly responsible for the mortality among young waterfowl. But in our marsh I am quite sure that this showy predator is far outclassed in destruction by another mammal which does no advertising but which is present in large numbers and, as baseball slang has it, is always pitching. I refer to the brown or Norway rat. The presence of sanitary fills in the district has attracted hordes of them, and although they are trapped and poisoned continually they have a cunning and adaptability which enables them to exist in unbelievably large numbers. I have seen them just before dark as they ran about the marsh margins, on the prowl for nests, young, food dropped by visitors, sickly or dead fish, or anything of food value. I have watched them swim short distances as they cut across an inlet. I have heard that in many places they climb about in trees. They have been responsible for the destruction and total elimination of many ground-nesting birds. They have spread to every country on the globe. They are the archpredators, not because they are always more ferocious or active than the local predators which they sometimes replace, but because their fertility and adaptability enable them to meet all conditions. In the marsh their work is furtive. Now and then I hear that a rat has been seen feeding on a dead bird, the implication being that some 
other creature, probably a mink, had killed it and the rat was performing a useful duty as a scavenger.

And thus it is that the mink which I have watched for many years, and which I am quite sure is locally limited to perhaps a dozen pairs, is charged with the destruction of the young ducks, while hundreds of brown rats, persistent destroyers and hunters of eggs and young birds, are entirely overlooked as predators, though they are feared and hunted as possible carriers of disease. This attitude toward the mink is held in spite of the fact that it is a hunter of rodents as well as of birds. It probably devotes much of its time locally to the destruction of rats, which are easily taken when young and which can always be found in the area. The mink is not a gregarious creature like the rat. Annual trapping for its fur keeps its numbers small, so that there is little possibility of an increase in population. There is even reason to believe that the destruction of rats by mink in the area might possibly assist in the protection of mallards, even though the mink is known to take them.

This then is an example of the complexities of conservation. The position of the predator is seldom clear, but varies with location and conditions. The question of who killed Cock Robin is not easily solved, and the remedy for such situations must be applied with care. There are always problems in the background which can be resolved, if at all, only by long and careful study. Snap judgments arrived at by the superficial are often more damaging than leaving the problem in its status quo. Samuel F. Rathbun, one-time director of the Washington State Game Department, told me of a situation, similar to that in our marsh, which occurred in the eastern part of the state. A good breeding place for ducks was being constantly raided by what were thought to be mink, weasels, or other native predators, and a request was made for a trapper to eliminate the culprits. When the situation was examined it was found that the losses were 
due to brown rats which had come from a very small dump situated at some distance. When the condition was corrected at its origin, the difficulty stopped, but had remedies been applied without an investigation. much useless expense would have occurred.

In my years of marsh observation I have seen few cases of predation or apparent predation which were clear and definite enough to justify immediate action. For example, the crows come to the marsh each spring, and knowing their sharpness and ability to take advantage of all food opportunities, I thought for some time that the birds annually made a practice of raiding the nests of the tule wrens, the redwings, and the flycatchers. One day I saw a crow carrying a young tule wren. This isolated case was my only evidence, but I could see no other reason for their activity at that time of year. Then I noticed that there was a small but constant mortality among the spawning carp. I saw some crows feeding on one of the carcasses. Never again did I witness further predation on the young marsh birds and so, in spite of many regular visits, I am now uncertain whether there is regular predation on the young of the small birds, whether the crows are attracted by the dead carp, or whether some other kind of food brings them.

Such experience has taught me, as I think it has taught all unprejudiced observers, that too-hasty action has no place in wildlife management, and that all possible information about any creature's habits must be collected and weighed before any control is considered necessary and decided upon. A classic story on this matter was told me by one of the leading authorities in the field. It concerned a bass lake in the northeastern part of the United States. One of its owners advanced the seemingly logical theory that, since the lake contained a limited amount of food available for fish and since the owners were interested only in bass, the obvious way to increase their number and size was to elimi- 
nate all other kinds and reserve the resources of the lake for bass only. They proceeded to drain the lake and to remove all other fish. Two or three years passed and my informant received a request to visit the lake and to determine, as a parasitologist, why the bass had become wormy and unfit for consumption. His first task was to identify the parasite; his next was to determine which of the fish that had been removed had controlled the pest. After a series of trials he discovered which species had been responsible. Convinced that he had found the source of the trouble he told the lake owners to put these fish back and their troubles would probably be over. This proved to be the case. To him, it was one of many proofs, he said, that the disturbance of natural balance was often a dangerous and delicate business.

Another case along similar lines involved the harbor seal on the Pacific Coast, an animal which both the commercial and sports fishermen consider a great destroyer of salmon. A few men who had spent their lives studying such situations were not so sure that the seals were as guilty as charged. One of them deplored the fact when the state finally put a considerable bounty on harbor seals. When I remarked that there seemed to be plenty of evidence that the seals took salmon, he agreed, adding that the salmon had many other enemies, notably dogfish. What he would like to know, he declared, was what the harbor seals fed on during the months when salmon were not numerous on the coast. When I asked the reason for his curiosity he said that if, during that period, the seals fed on dogfish and on other predators of the salmon, it might be that the good they did by reducing these other predators was far greater than the damage caused by direct attacks on the salmon. At any rate, he considered this factor the crux of the whole problem and said that it was possible that the action taken was not only a financial waste but also, by relieving the pressure on the other important salmon predators, was causing a net loss in the salmon crop. He 
thought that further investigation was necessary to justify the continuance of the bounty on the harbor seal. Thus what looks like a problem of simple predation becomes a complicated and doubtful affair.

There is a great advantage in confining much attention to one small marsh. It lies close to my home. I can see the workings of the whole, which is an advantage not found in a large area. If desirable, I can visit and revisit it two or three times in one day. I think of what Browning said in "Pisgah Sights":

\section{Peering and prying \\ How I see all of it \\ Life there, outlying.}

If, in my visits, I think much of predation, it is because I cannot escape it. It is always about me. I paddle my canoe through a community where predation is the rule and where all living things are affected by it. The balance of nature of which we hear so much means, crudely defined, that all forms of community life have a tendency to adjust themselves in an interlocking and smooth-running organization. In this community, as in most others, many members eat, or are eaten by other members, or both. The individuals perish but the species and community move on. The process is constant: a fly, of a sort which resembles a bee, moves over the surface of a lily pad and lunches on small insects which dot the leaf. Sated, it departs. There is the soft movement of wings, the flash of a small bird, and a barn swallow neatly annexes the fly. Tomorrow some hawk may take the swallow. Such is the present pattern of marsh life. Almost certainly it has been the pattern for centuries. Interference with it may have strange consequences. Spread the new insect killers in the marsh and all may be well if it is done carefully, but improper methods may involve the elimination of the useful as well as the injurious, the removal of the insect food of the 
birds and their consequent death or departure, the elimination of insects necessary to effect pollination, and a consequent shrinkage in the productiveness of the area, and in the number of birds and mammals which are able to maintain themselves.

Natural communities appear to have a quite efficient way of operating. The relationships are those of the ages. It would seem that they should be interfered with as little as possible and that any attempts to control future killers of Cock Robin should be made only after changes are proved to be absolutely necessary and there is certainty that changes proposed will not be accompanied by undesirable repercussions.

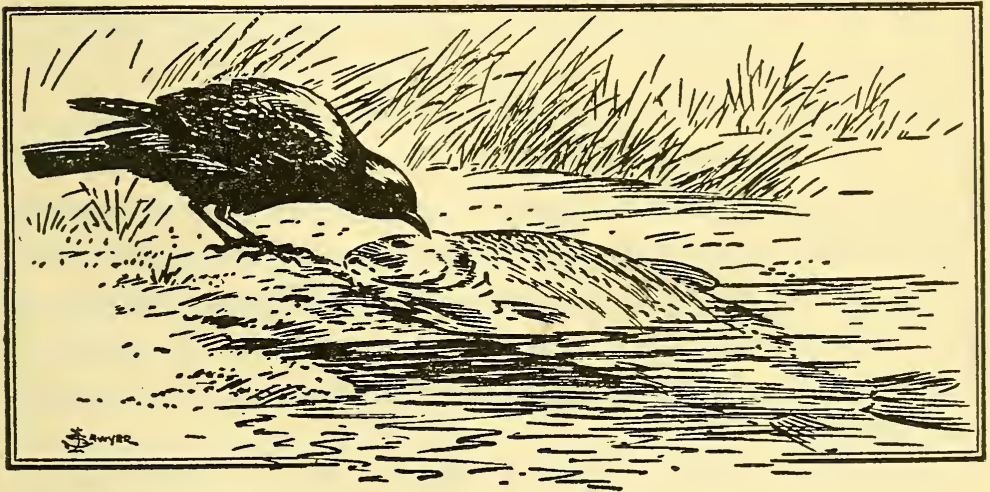




\section{Fog Is a Puzzlement}

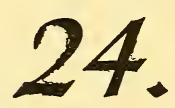

TO THOSE WHO WONDER HOW I could visit a small city marsh so often without exhausting its freshness and novelty, I will answer that I tried to adopt the photographic device of looking at the subject from new angles. The modern photographer, faced with the problem of injecting new life into routine assignments comprising the day's work, found that the presentation of his subject from above or below, from the side, or with lighting which rearranged the shadows and accentuated basic structure, or with various other techniques, produced spirited and satisfying results.

I applied similar methods to the marsh by varying my approach in every possible way. Early and late trips, varying phases of plant growth, water levels, nesting progress, migration activity-all affected the surroundings and produced changes in conditions. One week the area would swarm with certain insects, although I had noted none the week before. They had been attracted by the blooming of the marsh flowers. Or the lowering of the water level would bring in small flocks of shorebirds. Possibly the cattail heads would be torn by the strong winds of early winter and white fluff 


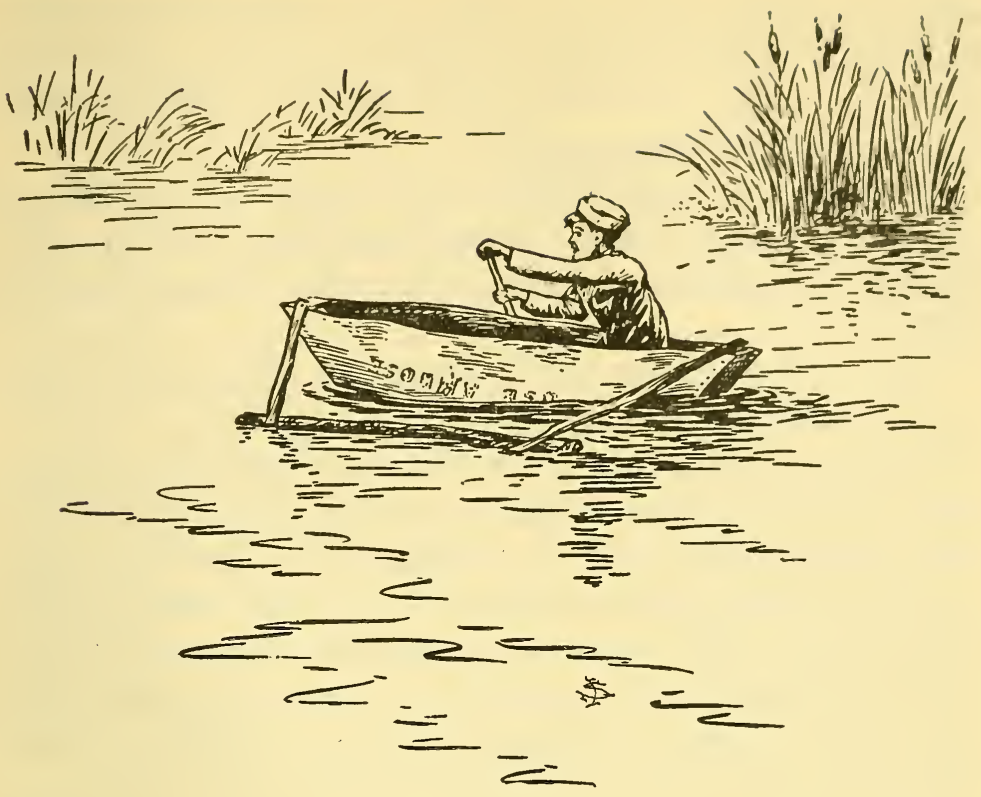

would float like soapsuds on the bay. Decided alterations in weather would shift the transient population or affect the behavior of the residents so that the wary birds of one week could be approached closely the next, or those which had been friendly would become shy and zoom away at the first advance of the canoe. These weather changes were of such importance that I tried to investigate them until eventually I felt reasonably well acquainted with all but fog.

I had been out in many light and a few rather dense fogs but had never visited the area in the totality of a regular Pacific special. This dense mass of condensed water vapor had formed off the ocean coast. It had been carried by onshore winds through the Strait of Juan de Fuca and into the Puget Sound basin. Now it lay heavily over the whole area. And so, that morning, I went to the canoehouse in fog so thick that I had considerable difficulty in parking my car 
where it would not be hit by others. I stumbled about among the canoes and succeeded in rapping my fingers against the side of the rack. I was nursing them when the manager came down from his living quarters.

"It's you," he said. "You're the last 'man I'd expect. I thought it might be some drunk floundering around and I wanted to herd him away from the water. You aren't going out."

"Why not? I've been waiting two weeks for just such a day. I want to find out what goes on in a soupy fog."

"I think you'll find it quiet, though I guess the animals have to rustle for grub in bad as well as good weather. Anyway, you certainly picked the right day. The fog's heavy enough to hold up a canoe. Be sure you don't leave the lake and wind up with your outfit on some dry street on the hill."

He launched the canoe and held it close to the float until I was seated. Then he dropped a couple of pillows on each side of me and threw over a light blanket and canvas.

"It will keep you dry and warm in this drip," he said. "Stay out of the main channel or a powerboat might cut you down."

It required only five paddle strokes to carry me from all sight of shore. The canoe was surrounded with a circle of water, black and oily close to me, grayer each foot away, until it grew more and more unlike water and more like the enveloping background. The canoe moved in an inverted bowl, the surface of which was formed by the denseness of the fog.

What could I do in this fog? One thing was certain: I could not rely on sight. The other senses must be my main source of new impressions. I had not pictured anything quite so dense. It made me think of a friend of mine. I apologized for my slow driving one thick morning, and he drawled in his southern manner:

"Sure is tough. You can't see much and what you do see 
don't look natural. I saw a sheep in a Georgia fog once. It looked so big I thought it was a cow 'til I got real close. Fog is a puzzlement."

I paddled slowly. The open space which surrounded me moved with my canoe. My hands became damp, my face cold, and tiny drops covered the canoe rails. I could distinguish clearly only the nearest objects. From a standpoint of visibility I might as well have been on some tramp windjammer out on the high seas.

High seas instantly recalled a boy who had haunted the swamp one summer. Herbie-twelve, quiet, sturdy, and khakiclad-concentrated on ships and the seven seas instead of the horses and cowboys so popular with his pals. He approached me frequently in a boat of his own making: an extraordinary affair fashioned from one piece of a sheet iron sign (painted advertising still visible), resembling a bathtub in the center and with the bow and stern shaped by nailing the sheet ends to strips of wood. An outrigger, held about three feet from the hull by sticks projecting from the ends, made it fairly seaworthy in the sheltered waters of the bay.

To me it was on the level of the hide boats of the ancients, but Herbie regarded it differently. He saw no defects, never apologized for its turtle-like slowness or its unpleasant habit of shipping water when the swells of boats struck it. His frequent references to distant seas indicated that he had read stories of marine adventure. I am quite sure that he seldom thought of himself as paddling about the marsh. He fancied that he was sailing in waters which man had seldom navigated.

That is why the thought of high seas recalled Herbie. A foggy day would have awakened his imagination and he would have become a Norseman directing his craft in stormy waters. His single three-foot paddle would have been the great steering sweep which he handled at the stern while he gave orders to the crew as they toiled at the bank of oars. 
Herbie would have had some such thoughts about the fog, notwithstanding the shore sounds which would have instantly destroyed any illusions which an older person might have tried to build up. If the sounds broke into Herbie's consciousness at all, he would have interpreted the shouts of playing boys as the cries of children begging for rescue, muffled traffic sounds would have been the roar of the seas, and auto horns the signals sounded to keep the ships together in the fog.

But there were no such connotations in the sounds I heard: they were the rattles of loads sliding over the endgates of the city garbage trucks, the noise of heavy traffic across the bridge, the bells of the ferry landing on Lake Washington, the chimes of the University carillon. I envied Herbie his imagination but, whether for good or bad, I must take my pleasure from the interpretation of tangible things.

I temporarily dismissed Herbie and continued my slow progress. I realized, as I had foreseen, that I was testing my reactions almost entirely without the greatest of the sensessight. I had never been so conscious of the pungency of odors, nor so aware of the little noises of the marsh-the creaks, the snappings, and the small and indistinct clicks which came from everywhere. The drops falling from the paddles, and even the little wavelets at the canoe bow, came to me as sharp, separate, and distinct sounds. I noted the smell of smoke from the University stack, the marsh gas which bubbled to the surface, and the mud displaced in the shallows by the canoe paddle. And then I heard a definitely close sound on my left-the noise of spattering water.

One glance in clear weather would have revealed the cause. Had it been early summer I might have thought that some nesting bird was making a display to divert my attention from its nest or young, but this was not possible in November. Equally unlikely was the pleasant thought that children might be playing on the beach. 
The idea was much more pleasing than the reality which my approach revealed. A splatter of water, a small head outstretched in the midst of the cascade, and a plump dark body which flapped its wings desperately and with the terror that only an entangled bird can display.

The trapped creature, a small green-winged teal, tried to move back but was blocked by the vegetation behind it. It plunged forward and when it disappeared from sight I knew why. Attracted by apple bait, it had been caught by the jaws of a muskrat trap. As the bird moved forward into deeper water the weight of the metal had submerged it.

I moved the canoe close and without waiting to pull up my sleeve I reached to my elbow in the icy water, secured the trap wire, and brought the bird to the surface. Its mad flapping wet me as thoroughly as if I were in a hard shower. Then the bird hung limp and exhausted. The frenzy was over.

I suspect that I should have wrung its neck then and there, for I knew the history of trapped ducks. This bird was only one of about forty that I had taken from muskrat traps, birds with bill crushed, wing broken, one or more legs smashed, or dead. I knew that few had lived, for. I recognized later their maimed bodies as they floated in the rushes. Few had any chance to recover. The life of a healthy bird is a constant struggle, and for the partially handicapped there is usually slow starvation or quick end by rat, mink, or other predator. I thought that I would examine this bird and free it only if it was in good condition. When I loosened the trap jaws a little the bird dropped into the water and instantly dived. I waited for a short time, then resumed my paddling with sleeve dripping and stag shirt profusely sprinkled. I heard the wailing siren of an ambulance; the marsh was not the only place where tragedy had struck.

The visibility diminished as I groped along in the midst of the fog which surrounded the canoe. I thought that I knew my exact location but I grounded within five minutes. I tried 
to push my way through and soon found myself situated so that I could neither go forward nor backward. I considered the matter. I was in the midst of the many exposed little flats on the west side of the bay. Deep water was near but which way? Traffic sounds indicated general directions but could not help me determine the windings of an irregular shore. Must I wait on this two or three acres of flat until the fog cleared? This was farcical adventure: to be stuck on a bar not ten minutes from the canoehouse. I was almost disgusted until I thought of Herbie. He would have considered it a time for realistic endeavor. He would have been a Tasman ashore on the barrier reef of Australia, or a pirate faced with the problem of getting his ship in shape to meet the tidal bore as it approached the South American beach where he was stranded. If Herbie could welcome such an apparent impasse, I ought to take my difficulty calmly. I started straight ahead and aided my progress by throwing my weight forward as I paddled. I gained a few yards and stopped almost breathless beside a small projecting branch. I suppose there are a thousand such sticks in the marsh, but rare luck had put me alongside one of the few branches that I would have recognized. I knew this one because there was a curious knot at the top which so resembled the snake-like head of the pied-billed grebe that I never passed the stick without noting it. I realized then almost to the foot where I was-only a fishrod's distance between me and a small channel which followed the shore line. I lunged and poled my way into it with no feeling that skill had been responsible for my release.

So many flats were exposed in this area that I determined to go along the shore where I could recognize my position. I knew of no other way to get through this baffling invisibility. In addition, more wildlife would be near shore than on the open water. The fog still enveloped everything. I wondered what the Indians thought of these dense visitations. Did they fear them as they did night? Did they hold some particular 
tamanous, or spirit, accountable for them? Did they think that evil deeds occurred while these ground clouds choked the land? Did they stay close to their camps as they did at night? Here were many things to ask students of anthropology.

That early morning I encountered many things which would have puzzled Herbie. When I headed the canoe toward the east I heard thousands of quick splashes merged into a continuous pattern, followed by a light roar for a few seconds and then by the sounds of many more splashes. As the canoe continued to the east this succession occurred several times. I think Herbie probably would not have bothered to give it a local explanation. To him they would have been porpoises off the port bow, or flying fishes leaving the water to escape their pursuers, or some other exotic creatures. I am sure that he would not have interpreted this activity as the rolling of a flock of baldpates, these handsome little ducks which spend much of the late fall and early winter in the open water of the bay. I could hear their calls, wheezy and musical, like the cries of the first dolls which talked when a bellows-like contrivance located amidship was squeezed. I could visualize the action of the birds as the nearest strip would noisily rise and fly over the birds farther away and then land in the first unoccupied water. This maneuver would be repeated by the next nearest strip, until some part of the flock was nearly always in motion, and the whole effect was that of a cylinder rolling and advancing.

By the time the baldpates had left the area I heard the crows calling as they moved away from one of the little islands which appeared in the center of the bay when the water was low. The place must have furnished good feeding, for these black opportunists who never overlooked good food could always be seen hopping over it.

To mention difficulty in getting over a four hundred acre bay seems absurd until one thinks of it in terms of almost 
complete lack of visibility. I was in much the same position as I have been when I awoke at night in a strange room and tried to find my way to a door or a closet. There were no landmarks, shadows, or aids to direction.

I listened for the sound of birds but they had moved to a quieter part of the bay, and I heard only the distant murmur of the calling baldpates. The center of the bay offered no more events of interest. I turned to the traffic sounds in the west and soon approached a shore which, when I was three or four yards away, loomed up as a few perpendicular narrow stripes, then assumed more shape and detail until, a paddle length away, I could distinguish cattails and other marsh plants. This approach showed the typical pattern of the marsh fog; it began with formlessness, merged into blurriness, and changed, at close quarters, into detail.

Movement among the birds increased in the channel I followed. They flew noisily before I could see them. Herbie, with no inhibitions of imagination, could have labeled them eagles, albatrosses, swans, penguins, or any other birds of adventure, but I was forced to place them by their cries, as bitterns, green-winged teal, coots, blue herons, and mallards. They flew noisily and grumpily as if irritated by the intrusion. I heard the cry of gulls far above and envied them their extradimensional ability which took them out of the ground obscurity. Undoubtedly the fog layer was not deep and they were flying in clear air above it. Thus they easily avoided the problems of the marsh residents in the murk below.

I speculated about these problems. A dense fog must alter the relations between the predators and the preyed-upon. It might give the hunted a respite or it could increase their danger by allowing the predator to approach closer before making the final spring. Or did the murkiness bring about a temporary truce? My experience was not sufficient to justify an opinion. I only knew that when I approached birds in a light fog, they seemed much more alert, and the ducks, bit- 
terns, and herons took flight more quickly than on clear days. Whether there was any regular pattern of foggy weather behavior could be determined only by extensive investigation.

Many sounds came to me as I followed the channel. They appeared somewhat different from those I heard on clear days. They were not muffled, neither were they clear. The bark of a dog in the student housing district, the brakes of an automobile, and the explosions of a back-firing truck had a quality that I could not understand until I realized they had a slightly muted effect, which seemed to alter their quality without reducing their strength. I moved the canoe slowly, stopping near some song sparrows and thinking that only they and the chickadees remained so sprightly and cheerful and showed such unconcern when storms visited the marsh. I tried to establish my exact location by moving close and glancing at two or three feet of shore. I found that many trips had made this quite easy. Occasionally I recognized bits of mudflats where I had stopped to photograph. My mind returned to Herbie, for here was the little spot where he had first approached me in his tiny catamaran as I was watching the activities of some pectoral sandpipers. There were the roots around which they had clustered and slept after they had bathed and preened. Herbie's first attitude had been one of indifference, but he regarded them with much respect when I told him of their long travels between Alaska, their nesting ground, and Patagonia where some of them wintered.

The swamp odors varied, sometimes acrid, often unpleasant, now and then strong with a suggestion of iodine or carbolic acid. The odors, the neighboring sounds, and the quick views of close shore patches summed up the possibilities of the day. The result was one of restfulness. I had no need to reach constantly for my binoculars or to twist my neck for the sight of a bird that had flushed after the canoe had passed. I could not watch for fish in the shallows below or 
for frogs or snakes sunning themselves on the banks. Fog blurred action, limited the workable area, and consequently made less demand on one's attention. Fog reduced necessity for action because it prevented any anticipation of action. There was an impulse just to drift.

But I did not forget that there was real danger from fog; a real reason why one must always mistrust it. Even in the bay there was the possibility of a careless capsize which would send the boat adrift in the haze and leave me floundering in a sea of muck. I thought of how helplessly I could grope about if there were no sounds to guide me. It made me understand how people who had lost their vision could never have any real feeling of certainty. No good for them to light the single match or to turn on a flash for the one look which would instantly give a bearing. Their darkness never could be resolved-it was a constantly enveloping medium. There must always be a feeling that, regardless of all safeguards, times would come when they would find themselves in a terrifying nothingness in which they must helplessly stumble. Whether the space was great or small they would have no way of measuring it, nor of taking action if they measured it. Flat space or edge of chasm, how difficult to know the difference.

I ate some sandwiches and found that I felt much more comfortable. I decided that fogs were irritating and certainly slowed things up, but they could be managed as long as conditions were under control. That appeared to be the important point in contact with this condition, for its obscurity could be a cruel and relentless factor if circumstances were unfavorable. If, instead of being in the compactness and the security of the marsh, I was far from land on a great lake, or on tidal water where currents ran swiftly and rocks reared their sharp tops, then any lack of visibility might put me in great peril. The difficulties of flying would be more grave than of boating. I thought of the man who flew about in the 
fog near an airport in New England. His plane was of the type that Herbie would have liked, a single-seater, fast, small, and dashing. But he was without instruments, and when the vapor constantly thickened he could not land. People below heard him as he circled and vainly waited for a hole that would let him down. What must have been his feelings as the gauge marked a steadily decreasing supply of gas until finally he must have realized that the fog was not going to thin and he had no chance? How much anguish can a man experience in two hours? Three times in my own life I have faced sudden death and I can say there was no regret or fear at the time because the crisis came so swiftly. But when the end is delayed and yet certain, much horror can be packed into that short period.

Even for birds the air is a bad place in a fog. The records bulge with stories of the terrific casualties suffered by winged migrants. Lights attract and hold them so they circle constantly until, like the airman, they crash. Bushels of small birds have been found dead at the base of certain lighthouses. So heavy has been the destruction that the government has put landing racks on many lights to enable the birds to perch and rest.

I moved along as slowly as possible and with only light and widely spaced paddle strokes. I followed the bank and continued to watch the small visible area. It was like looking through glasses which concentrated on one spot to the exclusion of all others. To see one tiny section of the marsh was quite different from viewing the whole as I usually did. And I suspect that the freedom from any possibility of danger due to the invisibility increased my pleasure.

I have a friend who has met fog under entirely different circumstances. He was a quartermaster on a vessel operating between Seattle, Alaska, and the Aleutian Islands. His stories manifested no liking for fog. He told of narrow waters, tremendous tides, and twisting channels. He described the diff- 
culties of determining the ship's position, the complex reckoning which involved speed, tide, wind, and drift.

The reality of this marsh fog brought his stories into strong relief. I could close my ears to traffic, peer into the fog and see my friend's ship plunging into subarctic conditions with a lookout aloft who could glimpse little more than high sheets of spray, with men in the navigating room plotting the course, and with the ship's whistle eternally blowing as a warning to other craft and as a method of detecting and measuring the distance from land.

It was not the modern method of navigation, my friend said, but it was one which had been followed for centuries. He described the swift currents and narrowness of the fogfilled passages and the tragedy of captains who had grounded their ships after a lifetime of successful navigation. Fog was hated and feared by the men, the owners, and the underwriters.

Now, he explained, the systems of aerial and sea navigation had been completely changed. By the use of radar and kindred equipment the navigator could pierce the fog and view all the mist-enveloped objects before the ship. Shores, cliffs, ships, icebergs, and islands appeared on the receiving screen and made navigation possible with security.

That, I thought as I paddled along, completely changed the character of fog. Night could be illuminated by powerful apparatus so that it approached day in visibility, but fog had been a cloud impenetrable to vision. Ordinary sight would still find it impenetrable, but the proper equipment was now available to reveal the presence and position of fog-surrounded objects almost as well as in daylight.

As I looked about the vision-blocked marsh I thought that some day portable sets might be available so that an individual who was interested in studying wildlife could peer into the fog and determine how the fog-bound dwellers of the marsh behaved. 
But I decided one thing as I paddled leisurely toward the canoehouse in the slowly thinning mist. If Herbie joined the many lads who were following the sea, I was glad that he would not have to navigate as men had formerly done, and that he could stand at the wheel in the denseness of a Pacific fog and know with some certainty what was ahead. 


\section{The Specialist Loses Control}

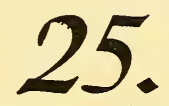

I STOPPED TO TALK TO THE CAnoehouse manager on my first trip to the marsh during the January storms. I found him shoveling snow which filled the surrounding hollows and drifted back and forth with the varying winds. His two dogs romped about, playing together, and tossing the snow which so seldom visited the marsh.

"I see you have built a new feeding place," I said. "I thought you had stopped for good."

"So I did. The birds seemed to get along as well without it. But they were never in worse shape than now. The storms are just too much for them. My wife and I don't enjoy watching things starve."

I knew how he felt. Many others felt the same way. All over the city people were putting out suet, grain, and dried fruit.

"Are you getting much patronage?" I asked.

"Plenty. Every marsh bird but the bittern. It acts as if it enjoys starving. Small birds like juncos, song sparrows, towhees, and chickadees came first, then bigger birds showed up. Hunger certainly took the fear out of them. They are beginning to act like barnyard hens." 


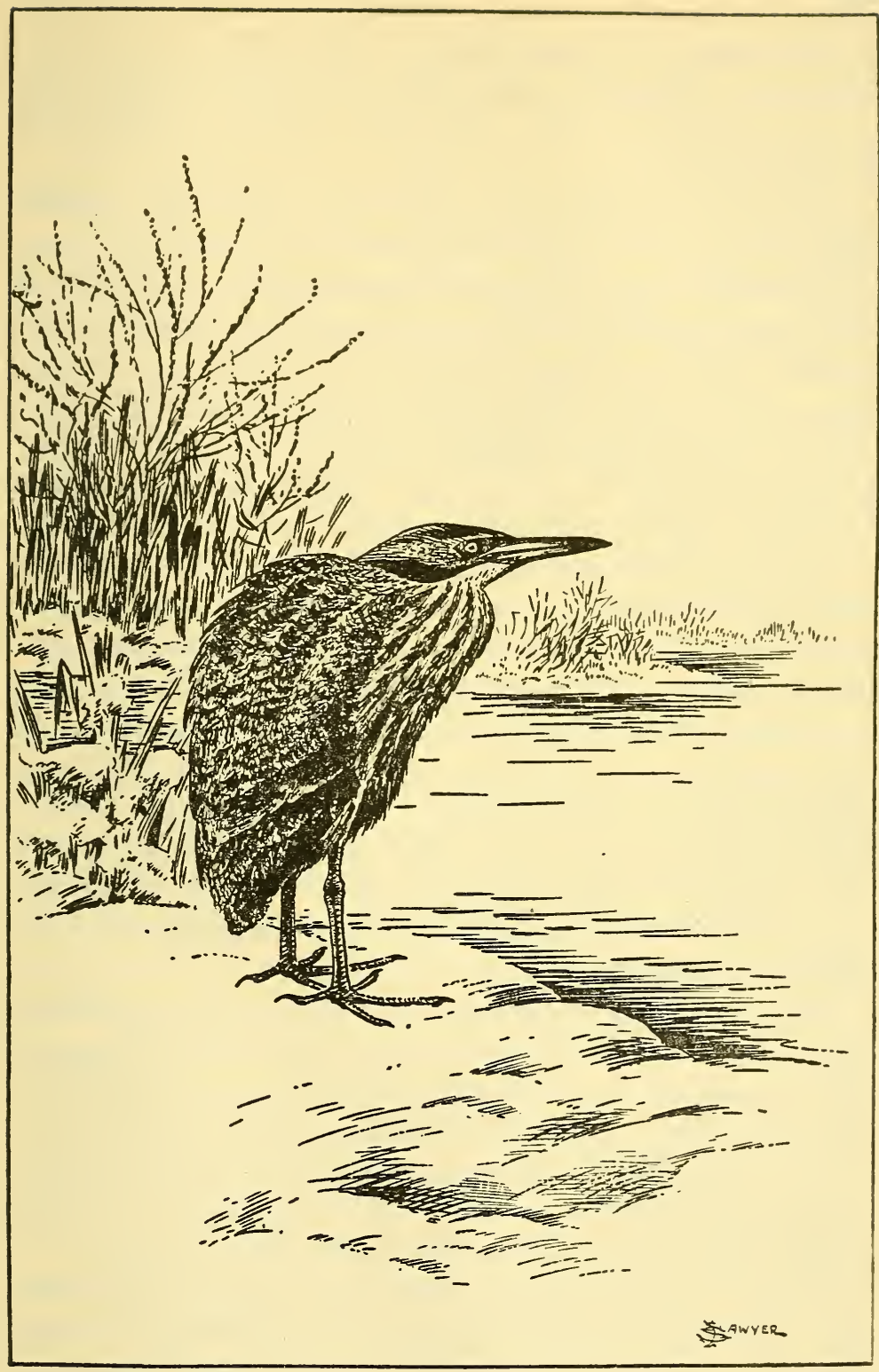


"That shows they need help," I said. "Snow that creaks when you walk on it and that drifts waist high is nice to look at, but it belongs to New England, and these birds aren't used to it."

People did not like such weather any better than did the birds. It had been the worst January in years. The newspapers told of many broken weather records, such as longest cold spell, greatest snowfall, and lowest temperature. Storms blocked traffic and closed schools and factories. Farmers were unable to get feed to their livestock. The dispatches called attention to the desperate condition of families which had been cut off without fuel and supplies. Relief authorities had to use tractors and planes to reach outlying districts.

I read much about the effectiveness of the aid to man and his stock but little about aid to wildlife. I thought about it every time a storm howled about my home. How was wildlife faring? The wild creatures of the Puget Sound area were accustomed to mild days and open water, with only a few short periods of snow flurries and frosty weather. What was happening to our birds? What had become of the bitterns which remained when their fellows migrated? They were now trapped in this most severe of all winters. Were they and the other marsh residents getting enough food? I decided to investigate.

The manager and I moved in front of the canoehouse where we would be out of the wind. The new feeding tray was on a post a few feet away. Bread and grain half filled it and some of the scattered contents had dropped on the snow. Two hen pheasants fed on the ground while small birds chattered as they flew back and forth from the low willows nearby. Then I saw birds in the shelter of the shrubs.

"Why, those are Virginia rails," I said. "Nobody could mistake their slender bills and ruddy color. It's the first time I ever saw them come to a feeding tray. I thought they would only eat snails and other small marsh life." 
"Maybe so," he replied. "But that kind of food is either a foot under snow or four inches under ice. They have to eat something." feed?"

"So does the bittern," I said. "But you say that it refuses to

"Seems that way," he replied. "It just stalks around without paying any attention to the tray or the other birds. I think it's the bittern that was around the float all summerthe one that kept fat on tadpoles. I guess it's still thinking about tadpoles and wants nothing else. I never saw a skinnier bird. It's a goner if the weather stays this way."

I went out on the float to look for the bittern. I found it on shore near the projecting top of a clump of weeds. It glared at me as if denying my right to intrude, stood a few feet away, and then moved away with shoulder feathers slightly raised and big feet making conspicuous tracks where the snow was soft. If the bird was hungry its steady gait did not indicate any weakness or inability to withstand such conditions.

I remembered the first bittern I had seen. While paddling one day my attention had been attracted to the cattails along the bank of the marsh. Some break in the continuity of line, a slight irregularity in the pattern, told me that a foreign object was there. What happened when I stopped the canoe could be compared to the dissolve in a change of movie scene. As I looked at the spot, the cattails lost form and were replaced by lines and patterns which were not those of the marsh but of a bird-a chicken-size stocky brown bird, the breast of which was striped or streaked vertically in a way which reminded me of the shirt of an English soccer player. For the moment the long and sharp bill pointed directly upward. The legs were strong and yellowish-green and the eyes yellow. The neck was outstretched.

I have learned much about the bittern since that first meeting. I found that it was a resident of many of the marshy 
areas of the United States, raising its young in nests usually situated in or at the edge of the marsh, sticking to the ground and seldom flying except in migration or during the mating season. I observed that it often drew its neck close to the body and so altered its silhouette that it looked like a different bird. Its call, oong-ka-choonk, sounded to me exactly like the grunting of a pitcher pump which brought the rain water from my aunt's cistern to her kitchen. I had watched the spring flights of the bitterns over the marsh. They were made, I was certain, to impress their prospective mates. I occasionally saw one of the young-perverse infants which, when faced, often refused to rush into the cattails, but merely ruffled their feathers and resentfully defied me before moving away.

The question of how these big and slow birds could exist successfully in an area of low growth and limited size puzzled me for a long time. Obviously, flight was not the answer. Ground speed was not enough. What other method was available?

Observation taught me that this bird relied principally on concealment. Even if time were plentiful, it refused to fly or to rush into the shelter of the marsh growth. Instead, after settling into a steady position, it stiffened its body, erected its neck, pointed its long bill vertically, and faced me so that the light and dark browns, and the white streaks of the breast, paralleled those of the cattail and reed background. And there it would stand. Trucks could rattle by on the highway, powerboats could swish within a few yards, planes dip, canoes splash by, or bombs explode at the beginning of the football game, but the bird would remain motionless. "Easy does it" seemed to be its motto. It seldom made a move unless the too-close approach of an intruder indicated that its attempt at concealment had failed and only flight remained. I could find no fault with its system, for the bird was a master of camoutlage. 
But I had never before seen it under the conditions that existed during those January days. Ice topped the water of the lagoons and white fingers had solidified in every shore indentation. Out in the bay the vapor rose as if from Paul Bunyan's soup kettle. The roofs of the houses carried a heavy load of snow. The willows and cottonwoods were cased in the sleet of night storms and the heavy hanging branches were white like the snow cover beneath them. I kicked the crusted snow with my ski boots and wondered what a bittern could get to eat in such an area and where it could find suitable cover.

For a bittern is a specialist not only in the art of camouflage but in its diet as well. It is no vegetarian, but concentrates on animal diet including snails, shellfish, crayfish, tadpoles, frogs, small bullheads, dragonflies, and other such residents of the area. It is a complete marsh specialist, adapted through the ages and expert in such surroundings. At first sight this manner of living appears to be without flaw or objection-a recognition of the modern idea of narrowing one's life to one phase of one field. In the main I suppose this is satisfactory. I watched the successful operation of the bittern for a dozen years and not until this January did I discover that specialization could be subject to severe penalties.

The penalties were not imposed on the summer residents, the bitterns which practiced their specialty when conditions were favorable: when the marsh growth was full of dark pockets, easy retreats, and with lines and shadows which followed the bittern pattern and allowed them to pose quietly while other wildlife and man came close to them. At that season a supply of desirable food was available and comparatively easy to obtain. The problems then were merely those of a bird living in an area for which it was conditioned. But most of those summer residents had left when the marsh began to slump and change color and when the small annuals dried in the fall wind. Perhaps only two or three birds 
remained after the general exodus: they were the ones which were to teach me that a specialist under adverse conditions is in a sorry plight.

For what could a specialist, whose safety depended upon waving cattails and heavy growth and dark shadows, do when most of the vegetation lay in heaps on the ground and under many inches of snow? Brown and white stripes offered no protection. The snow-covered ground reflected light into every cranny and removed the protective shadows. And how could a creature which depended on animal food gain a living when the sources of such food were sealed.with snow crust and ice?

In the summer I had often seen the bittern on a small point just opposite the bank which I passed. It had fished there regularly, feet in soft squishy mud, sun on its back, lethargic, comfortable, and confident, I assume, that almost any time it could pull a fat tadpole from the water. Did memory, or that which takes the place of memory in birds, make it feel that since tadpoles were once there they should always be there regardless of season? I could not think that this bittern was to die because only animal food would satisfy it. I asked myself why a bird of this kind could not be equipped with a more flexible sort of behavior pattern so that if frogs and other favored articles of diet were not present it might take something that would furnish temporary relief. Men who got desperately hungry chewed grass or leather, drank coal oil, or even ate dirt in the hope of getting some nourishment. Why shouldn't a hungry bittern go through the motions of eating and in so doing get hold of seeds or roots or something nourishing enough to prolong existence? Such narrow limitations appeared unjustified. Was it reasonable that specialization could be carried so far that its practice meant death to the specialist?

I walked back to the float. The clouds had not lifted, but they were so thin that the sun showed faintly through them. 
The north wind would clean them out before dark and that would mean a colder night. The ice cracked and grunted. The snow lay clean and unmarked except where two trails crossed it. In the mountains there would have been hundreds of footprints to indicate the passing of large and small residents, but so many feral cats and hunting dogs roamed the marsh shores that rabbits were absent and other small mammals few. Several hundred gulls sat, or slipped about, on the ice at the mouth of the cove. Only the chickadees retained their activity; they flew from bush to bush and kept up a constant chattering. The storms might begin again but they would manage to find food.

The storm did begin after a cold night. Snow fell intermittently for three days. When I again saw the marsh the snow had deepened and left the baseball field as smooth and white as a mountain meadow. Certainly conditions for the birds had not improved. I looked for bittern tracks as I walked along the shore toward the canoehouse but the snow cover was unmarked. The manager met me and we walked toward the feeding station.

"How's the restaurant making out?" I asked.

"Fine. I get a couple of new boarders every day."

"Has the bittern taken on vegetarian habits? I've been worrying about it?"

"You had the right hunch. See what's in the garage."

He opened the door and there was our friend the bittern which lacked the flexibility to deviate. It lay on the floor without moving, but when we got within a yard it opened its bill and hissed. When we stood quietly it lowered its head and watched us closely.

"The dogs found it on the float this morning," the manager said. "They wouldn't hurt it but they knew something was wrong, for they circled and barked until I came. The bird was so weak that I could pick it up without gloves." 
"Its bill is long and sharp. You could get a nasty jab if it really hit you."

"Not in its present shape. It can hiss and open its bill and act mean, but it's too weak to make a single pass. The poor thing is just about starved."

"Have you tried to feed it?" I asked.

"What can I give it? Every day it passes up the stuff that the other birds eat. It's had plenty of chance to try everything I've got."

I looked at the bird. I had never been so close to one. My impression had been general. It was tawnier, and its bill and legs were sturdier than they appeared at a. distance. The body seemed larger, too. But the plumage impressed me most-delicate browns, tans and creams, mottled and freckled and barred in different tones. Here was all the loveliness and detail which placed the bird feather among the most remarkable of nature's creations. I noticed the creamywhite throat, the breast striping, and the black neck markings. The combinations of color and pattern explained the effectiveness of the camouflage.

I admired the attitude of the bird. Even though it was hungry, perhaps dying, it possessed the quality that my grandfather always referred to as staunchness. Its hiss met every one of our quick movements and its tenseness indicated its willingness to strike though it lacked the strength to do it. Scientists probably would have termed it the defensive reaction of an animal that was filled with fear. But whatever it was, I liked it and I determined to make some kind of an effort to help even though I was almost certain the attempt would fail.

"I know the director of the zoo," I said. "Perhaps he could save it by feeding it the kind of food they give their herons. I'm willing to try it."

The bittern lay as if on a nest when we placed it in a box. 
It snapped its bill and made its usual sound but made no attempt to strike. I could hear its claws scrape as I drove.

The director and two assistants greeted me with a cordiality that convinced me that I had come to the right place. The bird began its hissing as we drew it from the box. A boy, evidently the son of one of the assistants, laughed. I asked him what amused him.

"It's the noise the bittern makes," he replied. "I've seen lots of birds and I've heard 'em make funny sounds, but I never heard a bird growl before."

The assistant drew his hand along the bird's breastbone.

"It's thin and just about starved. We'll put it in with the waders and see if it will take food."

We entered the aviary and stood before the beautiful section which housed the egrets and herons. It was a tropical scene with a small pond in the foreground, a tree with branches where the birds could perch and climb, and with rich growth beneath. The small door in the rear opened and the assistant prepared to introduce the bittern. The birds observed the intruder and displayed some unrest by calling and fluttering their wings. The bittern hissed, opened its bill, but made no other movement. When the assistant dropped it lightly into the pond where some small fish were floating, I thought surely the bird would start feeding, but it moved slowly toward the other side of the pond, crawled over the edge, and lay down.

The attendant shook his head and said, "It looks bad but we'll do our best. We'll try to force-feed it if it doesn't eat. But we'll wait until evening."

The boy smiled sympathetically as I left.

"Don't worry," he said, "I just know it'll get along all right."

I was not so hopeful as the boy. I had seen the cure and release of many small birds which had been brought in with broken wings, or otherwise injured, but I had never wit- 
nessed the recovery of waders or divers which had been in distress. They suffered from the shock of handling and they would not eat. I knew of many people who had picked up oil-covered birds which were otherwise uninjured. They had done everything to bring them back to normal but few succeeded.

I returned to the marsh to look again at the unusual appearance of the snow- and ice-covered area. Ducks, coots, and gulls were dropping on the ice at the edge of the bay and I watched the ludicrous manner in which they landed. The coots seemed to have no control, the ducks little more. Only the gulls succeeded in making a reasonably dignified stop. My mind still clung to the bittern. Why shouldn't a bird alter its habits temporarily if necessity required it?

What was the reason for this restricted type of diet? One thing appeared certain: each animal with fixed food preferences must live where those preferences can be satisfied. An overwhelming urge to use only certain kinds of food would hold a bittern to places where such food could be secured. The great natural scheme of things emphasized stability. The inflexible desire for a definite diet might be the only method of preventing the building up of a gradual taste for grains and such products which would make the animal able to live in many other kinds of places and compete with other species of birds. In other words, our bittern must remain a specialist, regardless of consequences, in order that it and its kind might continue to be marsh dwellers and nothing else. I wondered if this theory might be the correct one.

The sun shone brightly, the sharpness of the air pleased me, and I continued my walk. I passed a spot where a little hill rose from the marsh. Out of the hill flowed a tiny stream, perhaps a couple of feet in width and three inches in depth. It apparently came from the University powerhouse, for it was warm enough to prevent ice from forming and to push the snow back from its margins. It crossed four or five rods 
of mixed alder and cottonwood, entered a culvert, and trickled into one of the marsh channels. Small as it was, on that day it was the only running water in the marsh.

As I stood in the drifted snow a small object burst from the shelter of the bank and skittered across the water and along the edge. When it stopped I noticed the reddish body and its striped rear underparts. The bird stepped into the shallow stream and, disregarding my motionless presence, began to probe with its long bill. I thought that here was one Virginia rail that had avoided the dole handed out by the canoehouse manager. I watched the bird for it was a rare opportunity to see a rail feeding. It probed as busily as pectoral sandpipers or Wilson snipes, its bill constantly pumping up and down and its feet leading it into new positions. Then I saw a larger shape a few yards away in the brush. It approached slowly along the stream. It was another bittern.

For the past two weeks I had been watching a bittern under much different conditions. That bird had been a specialist deprived of control over life. Every time I had seen it in the snow I had the feeling I was looking at an uncomprehending creature which was struggling to do what could not possibly be done, as a man might labor hour after hour through a waterless desert because activity was the only thing left to him. That bird had been weak, helpless, and doomed.

But along this stream I was looking at another type, a confident bird, a bird in good condition. It advanced step by step along the streamlet. Food may not have been plentiful but there was enough to sustain it. A bittern knew all the tricks of living and hunting under such conditions. The tiny stream held things which it could find and take and liked. I thought it strange that the other bird had not left its icebound habitat and traveled the short distance to the place where life was reasonably certain. Then I remembered the solitary habits and uncertain temper of bitterns and I thought 
that if the hungry bird had tried to enter by force this stronger one would have attacked and driven it away.

I waited nearly half an hour before the bird reached the spot where I stood. It had worked here and there, and $t^{l} l_{2}$ ough I had not seen it take food of any size I am quite sure that it was obtaining small things. And its plump and healthy appearance indicated no lack of nourishment. At last the bird saw me. It did not attempt its usual freezing. There must have been realization that snow and naked trees afford no camouflage background, for the bird rose immediately and flew. I took a short walk around the clump of trees to see where it had landed. Just before the streamlet passed. under the road was a shallow pool of water less than four feet in diameter. The bittern stood in this brush-free spot, in the center of the tiny pool. When I approached too closely it flew a few yards and dropped alongside the stream again. Evidently it felt that its salvation lay near this water and there it would stay.

I called the zoo the next morning. They reported that the patient had appeared to pick up a little and they had been quite encouraged. But though its hiss appeared stronger and its resentment at interference more violent, it remained in the same spot in the corner of the enclosure and would not eat. As a last measure they tried force-feeding but with no success. The bird passed away during the night. They were very sorry.

The manager, his wife, and I were very sorry, too, because five days later the weather suddenly moderated so that when I came to the marsh the scene had changed entirely. Brown earth showed through the snow, pools of water covered the ice, and in many places the banks were bare. The birds no longer clustered around the feeding tray. They had no liking for such living and accepted the dole only because they had no other choice. Now they were scattered over the whole 
marsh. If our specialist could have held out for a few more days it would have been safe.

I went to the little trickle that had remained unfrozen, and although I looked the whole space over and returned to it twice in the course of my jaunt, the second bird was not there. It was not until I passed the canoehouse that I saw a bittern walking along the banks which, when they had been frozen, had treated the former resident so inhospitably. But now much open water was about and the remaining ice was soft and rapidly melting. The rushes and grasses were free. There were many places where an enterprising bittern could take food, for in normal times there was no more productive area in the marsh. I had never seen a time when a bittern did not occupy this spot. There must have been much strife over its possession. Perhaps the dead bird had often defended it against the very bird which had moved from the creek and occupied the territory as soon as it could be done without opposition. The new occupant would have no difficulty from now on.

The old tenant had been eliminated but a new bird was now in control. For though there was much snow present, spring rushed irresistibly on. I noticed that the willow tips were turning a yellow-green and that the buds were fat. I knew that the Indian plum would be blooming within two weeks and that swallows would be seen on the bay in March. Then in the weeks which followed our bittern would be seeking a companion from the returning migrants and again the marsh would be full of the "stake-driving" chant of the mated birds. 






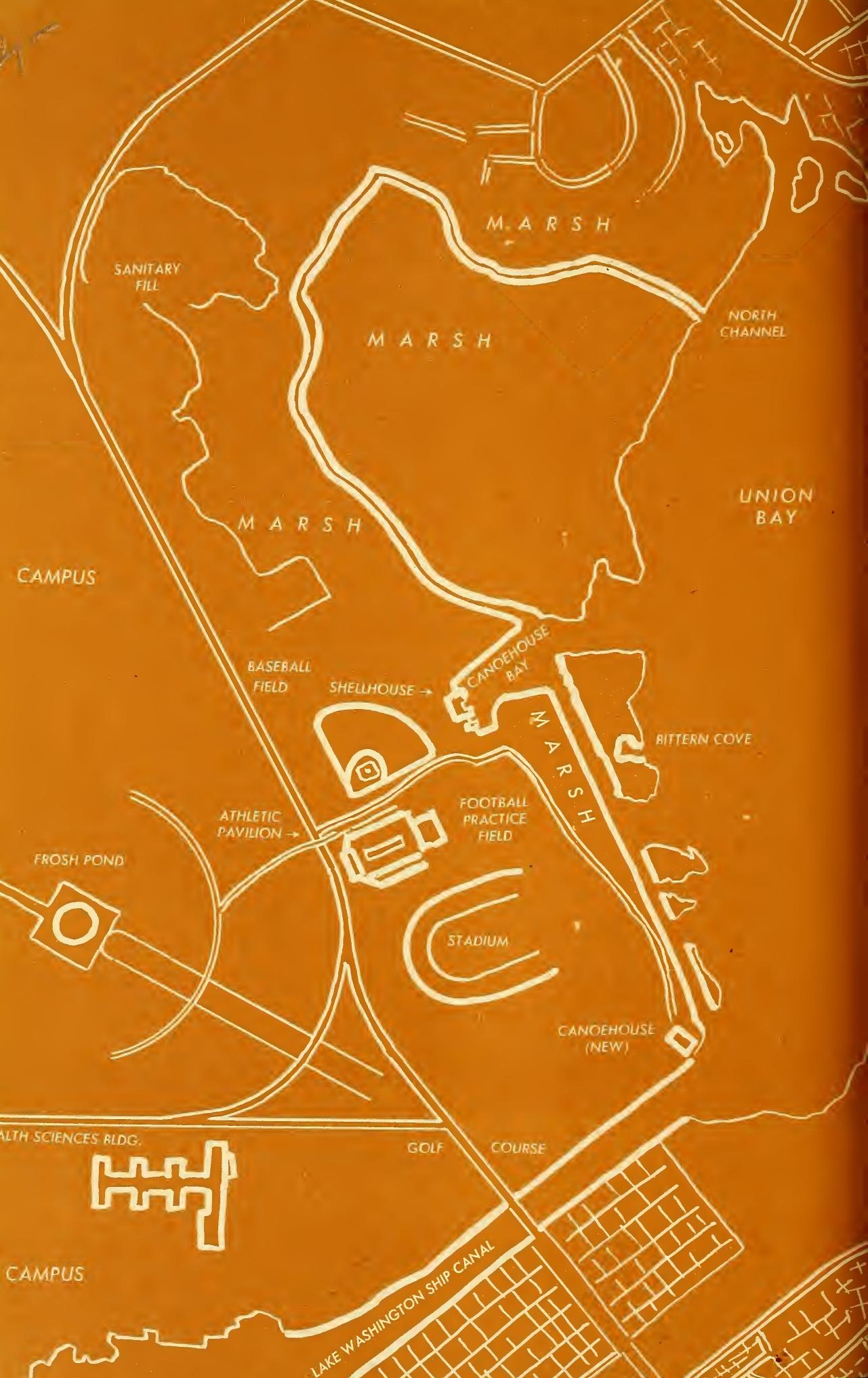



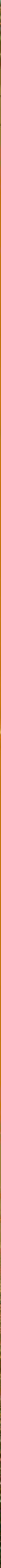


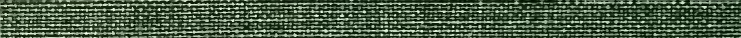

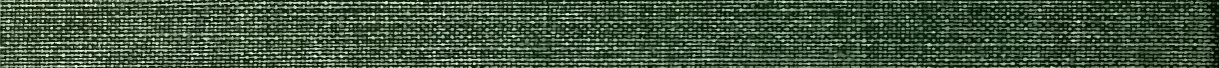

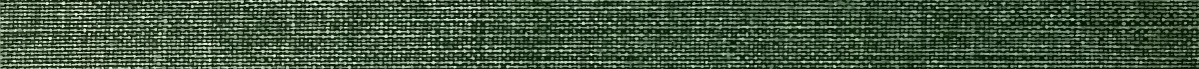

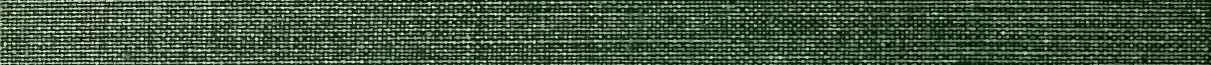

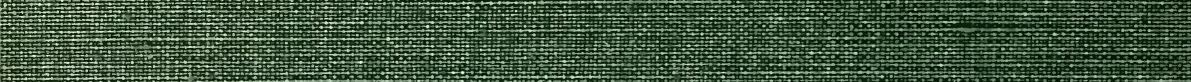
T.7.

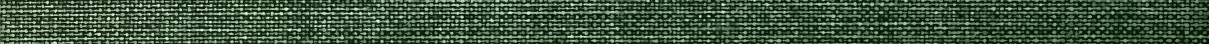

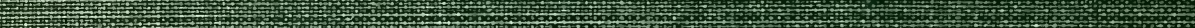
(1) J

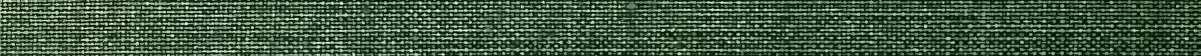
Fine

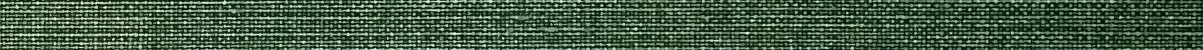

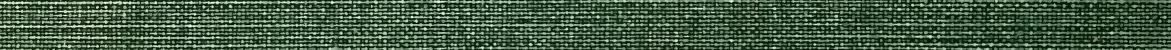
F

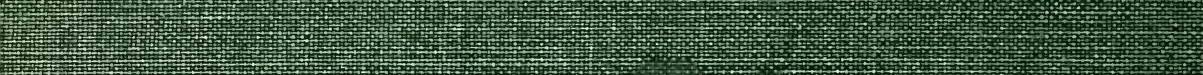

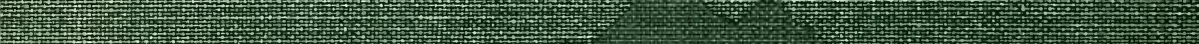
(1) (1) 